\title{
Revision of Livistona (Arecaceae) in Australia
}

\author{
A.N. Rodd
}

\begin{abstract}
Rodd, A.N. (Royal Botanic Gardens, Mrs Macquaries Road, Sydney, NSW 2000, Australia; Present address: 225 Trafalgar Street, Annandale, NSW 2038, Australia) 1998. Revision of Livistona (Arecaceae) in Australia. Telopea 8(1): 49-153. A taxonomic revision of the Australian species of the palm genus Livistona is presented, with a key to the species. Sixteen species are recognised, five of them described here as new (L. fulva, L. kimberleyana, L. lanuginosa, L. nitida and L. victoriae). One new subspecies is recognised (L. mariae subsp. occidentalis) and a new combination made at subspecific rank (L. mariae subsp. rigida) for Livistona rigida Becc.
\end{abstract}

\section{Introduction}

For the greater part of the period in which the Australian flora has been the subject of study by Western science, the native palms were neglected by botanists. Firstly, for a long period there were no resident taxonomists with an interest in palms. F. von Mueller and F.M. Bailey both described a number of palm species, but they dealt with them in a somewhat superficial manner, placing excessive reliance on very inadequate collections. Secondly, the sparsely scattered palms of Australia were not central to the interests of palm specialists such as Wendland and Drude, Beccari, and Burret, and they lacked adequate material for study. Thirdly, there is the combination of the limited economic value of Australian palms and the great difficulty of collecting and preparing specimens, with most botanical collectors unwilling to invest the time and energy required to make a satisfactory specimen. The latter two considerations have had the result that in Australian herbaria there is in total a very small number of adequate specimens of native palms, by comparison with almost any other plant group of equivalent size and diversity.

In the last two decades, though, Australian palms have been the subject of more intensive taxonomic study. Notable contributions have been the revisions of Ptychosperma (Essig 1978), Wodyetia (Irvine 1983), Oraniopsis (Dransfield, Irvine \& Uhl 1985), Archontophoenix (Dowe \& Hodel 1994) and Linospadix (Dowe \& Irvine 1997). In addition, the results of Irvine's unpublished studies of Calamus have been included in Jones's (1984) book on palms. This brings to a total of 24 the number of Australian palm species which could be said to be adequately covered by revisions, out of an estimated total of 53 species in 19 genera (not including endemics of offshore possessions such as Lord Howe Island); the present study will add another 16 species.

Past accounts of Australian Livistona are very incomplete and frequently in disagreement with one another. Wendland and Drude's monograph Palmae Australasicae (1875) has only five species: one of these is now known to be a Licuala, and another, Mueller's L. leichhardtii, an illegitimate name purporting to replace two valid names of Brown; this left only Brown's L. australis, L. humilis and L. inermis. The circumscription of the last of these names was greatly enlarged by Wendland and Drude to include east-coast plants now known as L. drudei and L. decipiens. 
Bentham's Flora Australiensis (1878) recognises only Brown's three species. Bentham shows by his notes and synonymy that he was aware of the faults of Wendland and Drude's treatment, but chose to adopt an extremely cautious and conservative species concept, perhaps excusable considering the materials he had at hand.

Drude (1893) in a rather discursive account attempted to clarify the taxa known up to that time, including Mueller's poorly defined L. drudei and L. alfredii. He attempted a comprehensive key based largely on fruit, in which some of the 'species' appear to be given a ranking subordinate to that of others. Drude made some perceptive observations but failed to formalise his conclusions.

It was Beccari who made by far the most valuable contributions to knowledge of Livistona, both in Australia and beyond it. The posthumous brief account (Beccari 1921, in Latin and Italian) of Old World Coryphoid palms followed by the very lengthy (1931) account in English, translated and edited by Martelli, increased the number of Australian species to 11 (of which 10 are still recognised in this treatment) and placed their morphological study on a much firmer footing. It is a testimony to Beccari's appreciation of the nature of variation in palms that he was able to derive such a sound taxonomy from the few and scrappy collections available to him.

\section{Historical}

Although Livistona was not recognised as a genus until so described by Robert Brown in 1810, the earliest botanical description of a Livistona appears to be that of Rumphius (1741-55), published in 1741 though prepared the previous century. Rumphius illustrated a palm from the Moluccas under the mononomial Saribus. Linnaeus (1753) included this as one element in his circumscription of Corypha umbraculifera; the other major element was Rheede's (1682) Codda-pana, characterised by a massive terminal inflorescence. Linnaeus's successors soon realised that his Corypha umbraculifera was a heterogeneous concept, and Lamarck (1786) separated the Rumphian element under the name Corypha rotundifolia. Moore and Dransfield (1979) formalised this effective lectotypification of C. umbraculifera. C. rotundifolia Lam. appears to be the earliest binomial applying unambiguously to a Livistona. It is currently known as L. rotundifolia (Lam.) Bl.

Loureiro (1790) described Corypha saribus from Cochin-China, though his adoption of this epithet bespeaks some confusion with Rumphius's Saribus, which in fact he cited as a synonym; but recent palm specialists, e.g. Moore (1963a) do not seem to regard this as a bar to its adoption as an epithet under Livistona (as L. saribus (Lour.) Merr. \& A. Chev.). Jacquin (1801) followed with the publication of Latania chinensis, now known as Livistona chinensis (Jacq.) R. Br. ex Mart.

Brown's (1810) protologue of the genus Livistona recognised two species, L. humilis and L. inermis, from northern Australia, collected by himself during the voyage of the Investigator and both beautifully illustrated by Ferdinand Bauer (but the illustrations not published until 1838, by Martius). Moore (1963b) has designated L. humilis as lectotype of Livistona. Brown's diagnosis of the genus hardly distinguishes it from Corypha, under which genus he placed a third Australian species now placed in Livistona, viz. L. australis (R. Br.) Mart.

The genus name was, in Brown's words '... in memoriam viri nobilis PATRICII MURRAY BARONIS DE LIVISTONE, ...', continuing in a laudatory vein to recount how Murray had over a thousand [species of?] plants laid out in his garden. According to Baines (1981) this was prior to 1680 and the garden subsequently became the Edinburgh Botanic Garden. It is clear that Brown deliberately latinized the Murrays' family seat of Livingston 
to Livistonis (ablative Livistone), from the inferred stem of which he derived the substantive Livistona.

Since Brown's publication of the genus, 58 additional binomials and 8 trinomials have been published in Livistona (Table 1).

\section{The genus Livistona}

A description of the genus is not given here, partly because of my lack of knowledge of its variation beyond Australia, and partly due to the existence of a very complete description in Uhl and Dransfield (1987). They treat it as one of 12 genera of subtribe Livistoninae, which in turn is one of the 4 subtribes of the tribe Corypheae. The Livistoninae are distinguished by their 3 carpels being free but the styles united; they have a wide distribution through the tropics and warmer temperate regions of eastern Asia, Australasia and the Americas, though with large disjunctions in the latter; one outlying genus (Pritchardia) occurs on mid-Pacific archipelagoes, and one outlying Livistona species in the Horn of Africa and southern Arabia. Both the distribution and morphological features of Livistoninae suggest they are one of the most ancient groups of palms.

Livistona has arguably the largest number of unspecialised features of any genus in the Livistoninae, or possibly in the subfamily Coryphoideae. Its closest ally appears to be the tropical south-east Asian Pholidocarpus, distinguished by its compound leafsegments, broader-based carpels and very large, usually corky fruit, among other features. However, some of the American genera such as Acoelorrhaphe, Brahea and Copernicia appear to be almost as closely allied, with leaves almost identical in structure to those of Livistona and flowers and inflorescence showing many similarities.

Of the 30-odd Livistona species, 14 are Australian endemics, 2 extend from northeastern Australia to lowland New Guinea, and the remainder are extra-Australian. The northwestern limit of the genus in Asia appears to be Assam (L. jenkinsiana) and the northeastern limit the southern islands of Japan (possibly as far north as Kyushu: L. chinensis). It extends eastward in the Pacific only as far as the Solomon Islands (L. woodfordii). It is doubtful that any major island of the Malay Archipelago has more than 3 or possibly 4 native species, with the possible exception of New Guinea, which has 4 named species (Johns \& Hay 1984) and probably others as yet unnamed; but there appears to be no species common to Papuasia and any other part of Malesia. Two widespread and variable species, $L$. saribus and $L$. rotundifolia, account for most occurrences of the genus in mainland Asia, the Sunda Shelf and the Philippines (see Beccari 1921, 1935; Burret 1941; Whitmore 1973). Borneo, despite its size and floristic riches, appears to have only one endemic species, the remarkable miniature L. exigua. After Australia the next major region of diversity for the genus, if unnamed taxa are taken into account, appears to be the hills and mountains of mainland southeast Asia and the Malay Peninsula: according to Dransfield (personal communication 1998): 'Peninsular Malaysia has L. saribus, L. endauensis, L. tahanensis, L. speciosa and an undescribed taxon that also occurs in Thailand and Lao. If we add in Thailand, then there is at least one more taxon, and going further north we can add two or three more in Vietnam and S. China.' The most remarkably disjunct occurrence of the genus has only recently been demonstrated, with Dransfield and Uhl's (1983) transfer of the sole species of Wissmannia Chiov. to its rightful place in Livistona, as L. carinensis. This species occurs in coastal Djibouti and Somalia in the Horn of Africa, also in a few sheltered valleys of the Hadramaut in South Yemen. 
Table 1. All known Livistona names, listed in chronological order. Those whose types are nonAustralian, or of unknown origin, are indicated by an asterisk.

Names that appear to be in current use are shown in bold type. Names now regarded as synonyms are linked by the ' $=$ ' sign to the name of the taxon to which they are believed to refer. This list does not include orthographic variants (e.g. jenkinsii / jenkinsiana) where they are clearly references to the same species.

Livistona humilis R. Br. 1810

Livistona inermis R. Br. 1810

L. chinensis* (Jacq.) R. Br. ex Mart. 1838 [Latania chinensis Jacq. 1801]

L. mauritiana* Wall. ex Mart. 1838

L. rotundifolia* (Lam.) Mart. 1838 [Corypha rotundifolia Lam. 1786]

L. australis (R. Br.) Mart. 1838 [Corypha australis R. Br. 1810]

L. bissula* Mart. 1838 $=$ Licuala $\mathrm{sp}$

L. gaudichaudii* Mart. $1838=$ Pritchardia gaudichaudii (Mart.) H. Wendl.

L. martii ${ }^{\star}$ Gaudich. $1842=$ Pritchardia martii (Gaudich.) H. Wendl.

L. jenkinsiana* W. Griff. 1844

L. spectabilis* W. Griff. $1844=$ ? L. hasseltii

L. subglobosa* (Hassk.) Mart. 1850 [Saribus subglobosus Hassk. 1842]

L. cochinchinensis* (BI.) Mart. 1850 [Saribus cochinchinensis BI. 1836] = L. saribus L. oliviformis* (Hassk.) Mart. 1850

[Saribus oliviformis Hassk. 1842] $=$ L. chinensis

L. altissima* Zoll. $1857=$ L. rotundifolia

L. diepenhorstii* Hassk. 1858

= Pholidocarpus diepenhorstii (Hassk.) Burret

L. hasseltii ${ }^{\star}$ (Hassk.) Hassk. ex Miq. 1868 [Saribus hasseltii Hassk. 1842]

L. hoogendorpii* Teysm. \& Binn. 1868 $=$ ? L. hasseltii

L. leichhardtii F. Muell. $1874=$ L. humilis

L. ramsayi F. Muell. $1874=$ Licuala ramsayi (F. Muell.) Domin

L. speciosa* Kurz 1874

L. papuana* Becc. 1877

L. mariae F. Muell. 1878

L. filifera H. Wendl. 1878 (nom. nud.?)

L. moluccana* H. Wendl. $1878=$ ?

L. occidentalis* Hook. f. 1887 (nom. nud.?) $=$ ?Brahea dulcis [Becc. 1921]

L. kingiana* Becc. $1889=$ Pholidocarpus kingianus (Becc.) Ridley

L. enervis* Hort. $1891=$ ?

L. alfredii F. Muell. 1892

L. woodfordii* Ridley 1898

L. muelleri Bailey 1902

L. benthamii Bailey 1902

L. rupicola* Ridley $1903=$ Maxburretia rupicola (Ridley) Furtado

\section{L. merrillii* Becc. 1904}

L. vidalii* Becc. 1905 = Corypha utan Lam.

L. microcarpa* Becc. $1907=$ L. rotundifolia var. microcarpa

L. whitfordii* Becc. $1909=$ ? L. merrillii

L. mindorensis* Becc. $1909=$ L. rotundifolia var. mindorensis

L. inaequisecta* Becc. $1909=$ ? L. hasseltii

L. decipiens Becc. 1910

L. robinsoniana* Becc. 1911

L. chinensis var. boninensis* Becc. 1912

L. blancoi* Merr. $1918=$ ? L. rotundifolia

L. rotundifolia var. microcarpa* (Becc.) Becc. 1919 [L. microcarpa Becc. 1907]

L. rotundifolia var. mindorensis* (Becc.) 1919 [L. mindorensis Becc. 1909]

L. rotundifolia var. luzonensis* Becc. 1919

L. saribus* (Lour.) Merr. ex A. Chev. 1919 [Corypha saribus Lour. 1790]

L. chinensis var. subglobosa* (Hassk.) Becc. 1921 [Saribus subglobosus Hassk. 1842]

L. tahanensis* Becc. 1921

L. decipiens var. polyantha Becc. 1921 $=L$. decipiens

L. holtzei Becc. $1921=$ L. benthamii

L. lorophylla ('loriphylla') Becc. 1921

L. drudei F. Muell. ex Becc. 1921

L. rigida Becc. $1921=$ L. mariae subsp. rigida

L. humilis var. sclerophylla Becc. 1921 $=L$. muelleri

L. humilis var. novoguineensis* Becc. 1921 $=$ ? L. muelleri

L. eastonii C.A. Gardner 1923

L. japonica* Nakai ex Masamune 1929 $=$ ? L. chinensis var. subglobosa

L. tonkinensis* Magalon $1930=$ ? L. saribus

L. brassii* Burret $1935=$ L. muelleri

L. boninensis* (Becc.) Nakai 1935 $=L$. chinensis var. boninensis

L. crustacea* Burret $1939=$ L. muelleri

L. melanocarpa* Burret $1939=$ L. benthamii

L. beccariana* Burret 1941

L. exigua* Dransfield 1977

L. fengkaiensis* X. W. Wei \& M. Y. Xiao 1982 $=L$. saribus

L. carinensis* (Chiov.) Dransfield \& Uhl 1983 [Hyphaene carinensis Chiov. 1929]

L. endauensis* Dransfield \& K.M. Wong 1987 
This pattern of distribution invites speculation as to the origins of the genus. Its diversity in Australia and presence in northeastern Africa suggest that its origin might be Gondwanan, and that it may have come into existence before the separation of Africa. The difficulty with this explanation lies in the absence of Livistona, or indeed of any closely allied genus, from the rest of Africa and for that matter from peninsular India and Madagascar. Dransfield (1987) tentatively advances the alternative hypothesis concerning the Livistoninae that: "The distribution of the whole subtribe together with a rich fossil record suggests its early differentiation in Laurasia followed by later dispersal in the southern hemisphere.' Although he states the likelihood that the Arecaceae originated before or around the time of separation of Laurasia from Gondwana and then developed independently in both hemispheres, he suggests that Australian Livistona 'may have originated in invasion from Sundaland; fragmentation of the ranges of Livistona in Australia due to climatic deterioration may have led to speciation. Far from being a Gondwanan relic, Livistona may, I now believe, be an immigrant.'

If Dransfield is right, such an immigration would have to have taken place after the collision of the Australian and Asian plates in the mid-Miocene (10-20 m.y.b.p): this rather brief time-scale hardly seems sufficient to account for the great diversity of form found in Australian Livistona, especially when taken in conjunction with the concentration of most of the species in refugia often associated with far more ancient land-surfaces, and the near-sympatric occurrences in some parts of Australia of such clearly unrelated species as, for example, L. humilis and L. benthamii. A third alternative, and one that is admittedly highly speculative, is that proto-Livistona had already emerged by the time Laurasia and Gondwana began to separate, and its progeny evolved independently but extremely slowly (by flowering-plant standards) in both landmasses and their daughter lands. This would more adequately explain the apparent relict status of many species, particularly the outliers, also the apparent divide between the species on either side of Wallace's Line. Uhl and Dransfield (1987), in their chapter on the fossil record, place the earliest appearance of palms in the early Upper Cretaceous (Santonian) of North America, and in fact this is a fan palm equated with the modern American genus Sabal in the Sabalinae, regarded as more specialised than the Livistoninae at least in floral structure; this generic assignment may be questionable, but it still suggests a great antiquity for the coryphoid palms. Unfortunately there is little in the way of Australasian fossil evidence (Dowe 1995) to support any general hypothesis as to the origins of Livistona. Except for the distinctive and taxonomically isolated Nypa, there appear to have been no Cretaceous or Tertiary macrofossils of fan palms reported as yet, and the fossil pollens, dating back as far as the Palaeocene, are either of the spinulose type assigned tentatively to subfamily Calamoideae, or are placed in the monosulcate form genus Arecipites. The latter covers pollen types found in a diverse range of modern palms, including Livistona.

\section{Morphology And Terminology}

An excellent account of the morphology of palms, accounts of the major groups and the genera, including features of inflorescence and flowers, is given by Uhl and Dransfield (1987). Tomlinson (1990) also gives a detailed, though more functionally oriented, account of palm morphology.

\section{Growth-habit and trunk}

With one exception, the Australian species of Livistona are invariably solitarystemmed, with a straight erect trunk - i.e. solitary and pleonanthic, fitting 'Corner's model' of Hallé et al. (1978). Only L. inermis sometimes exhibits basal suckering 
('Tomlinson's model'); this appears to develop only in older plants, sometimes quite profusely. Death of the original stem by age or fire is apparently followed in some plants by elongation of several (up to 6) basal suckers, resulting in a plant with several equal-aged trunks. Not all populations of L. inermis behave in this way, some reportedly being consistently single-stemmed with no sign of suckering.

Trunk diameter varies within and between populations of a species, but usually within limits of c. $25 \%$ of the median value for the species. Most of the Australian species can be accommodated in one of three mutually exclusive (or almost so) diameter classes, centred on trunk diameters of approximately 8, 15 and $30 \mathrm{~cm}$ at 1-2 $\mathrm{m}$ above the ground. Most species conform to a predictable pattern of relationships between diameter, height above ground, and age. In mature plants there is a basal swelling, much more marked in some species than in others, varying from gently bulbous to conical to flared like a trumpet; populations may show a certain degree of variation, e.g. from conical to flared, and much variation in degree of swelling, so that this character can only be described for each species in very approximate terms. In some stands of L. australis in the Sydney district it can readily be observed that the palms with greatest access to water, nutrients and light develop the most swollen trunks during their phase of maximum growth-rate, and these may have bases up to twice the thickness of less well-nourished palms in the same stand. Basal swelling of the trunk normally extends upward in an obviously conical form to a point 1-5 m (varying with species) above ground; above this the trunk appears superficially to be of constant diameter, but measurements of individuals which have achieved close to maximum height show a progressive though slight diminution of diameter continuing upward.

Old individuals of most species often display a phenomenon common in many palm genera, namely new root growth arising from subsurface layers of the trunk base at a point progressively further above the ground with age. This results in basal plates of surface tissue being forced away from beneath, with a dense mound or pedestal of exposed roots developing below (Fig. 1d). In some cases such pedestals can be over $50 \mathrm{~cm}$ high (e.g. L. mariae), or over $80 \mathrm{~cm}$ diameter (e.g. L. drudei). This can only be regarded as a significant character in these and one or two other species.

Surface pattern and texture of the trunk are moderately to very distinctive for each species. Most of the distinctive features are consequences of the particular pattern of aging, drooping and abscission the leaves undergo. On higher parts of the trunk, where crown size has stabilised and leaf-fall is regular, the leaves tear off cleanly with age leaving in most species a very regular pattern of thin sheath-scars which broaden for part of their circumference into the more prominent petiole-scars, which of course are arranged in the phyllotactic spiral. Sheath-scars and petiole-scars are often inconspicuous on the lower trunk. The petiole-scars vary from very smooth and flush with the trunk, to quite markedly stepped, i.e. with a projecting ledge at the lower edge of the scar, or more rarely are rather ragged with a torn fibrous edge. The pattern of scars on mature trunks is further complicated by the addition of inflorescence-scars. In a number of species the lower trunk bears persistent petiole-stubs, the result of leaves being shed from a weak point of the petiole some way out from the trunk, rather than from the base of the sheath (Fig. 1). These stubs may be somewhat sporadically scattered and confined to lowest $0.5-1 \mathrm{~m}$, or regular and overlapping (e.g., in L. eastonii; Fig. 1c) covering the trunk to about half its ultimate height; in L. benthamii they project almost at right-angles (Fig. 1a). This feature, although distinctive for a few species, may not be expressed in some situations due to frequency of fires or of strong winds.

A feature of Livistona trunks that is developed to a more striking degree than in most other palm genera is the presence of numerous vertically aligned fissures. As in most fan palms the peripheral trunk tissues are dead from an early age, and the fissures 
arise from the subsequent tangential shrinkage of this dead zone. They are often very crowded, deep, sometimes widely gaping, of varied length, and always cut across the horizontal markings (sheath and petiole scars) at random. As might be expected, species with very slender trunks exhibit less fissuring. Old trunk surfaces, as on the lower trunks of tall specimens, have generally undergone considerable erosion resulting in rounding and bleaching of the ridges, so that the fissuring becomes shallower and more obscure; in L. drudei the bases of older trunks often become almost completely smooth.

\section{Leaf}

The leaf in Livistona, as in most other palms, is a large, complex organ in which structural variation is evident over more levels of fineness than are normally examined in plant taxonomic studies. Its basic morphology, despite large differences in size between species, is remarkably constant throughout the genus in Australia.

The costapalmate leaf of Livistona can conveniently be divided into three major parts for purposes of discussion, namely the sheathing base, the petiole (including hastula) and the lamina or blade. These are dealt with under these separate headings.

\subsection{Sheathing base}

Aspects of sheath morphology of palms are covered in Tomlinson (1964, 1990, 1995) and Uhl and Dransfield (1987). The leaf base in Livistona does not conform exactly to any one of Tomlinson's (1990) types, but combines the dead mat of vascular strands of his Cocos-type with the elongated ligule of his Zombia-type. In the case of sheaths of these types Tomlinson distinguishes between the thin part of the sheath that wraps around the trunk apex, and the thickened part that forms a lower extension of the petiole: the latter he terms the pseudopetiole. In Livistona this is sharply distinct from the remainder of the sheath from an early stage of expansion, the distinction being in two features: (1) except at the extreme base of the sheath, there is an abrupt thinning from the pseudopetiole, which is concave-convex in transverse section, to the sheath which is laminar; (2) at least in its upper half, the line of junction between sheath and pseudopetiole is along the flat or concave inner face of the pseudopetiole, a few millimetres in from its sharp, usually prickly margin; thus the pseudopetiole overlaps the sheath (Fig. 2b). On older leaves the dry, fibrous sheath has usually torn away from the pseudopetiole and, since the latter forms a smooth continuum with the petiole itself, the only means of distinguishing it is the pair of intramarginal linear scars, often rather inconspicuous, where the fibres have torn away. For this reason the concept of the pseudopetiole has not been employed in the species descriptions, and the 'petiole' is taken to extend right back to the junction with the trunk. The ligule in Livistona usually persists as an opaque, smooth appendage, at least toward its apex, as it is not subjected to the stretching and disintegration undergone by the lower sheath. Nonetheless, it is often only on some of the younger sheaths that this apex remains entire; it takes the form of a roughly triangular or trapeziform lobe, its margin normally fringed with long, slender, entire scales, and its outer (abaxial) surface with an indumentum of mostly appressed scales, the bases of which are sunken in shallow pits, while the inner surface is always glabrous and more or less shiny. The size, shape, colour and texture of the untorn ligule apices are characteristic for each species, though differences between species are not always very obvious. It is unfortunate that the sheaths are seldom collected, though obtaining them is admittedly very difficult. Whenever the opportunity arises of collecting from a felled palm, they should not be omitted. 


\subsection{Petiole}

As used here, the term petiole will mean that part of the leaf extending from the point of attachment to the trunk to where the lowermost segments of the blade diverge (see discussion of pseudopetiole in previous section). The petiole exhibits a number of taxonomically valuable characters in its margins, surfaces and cross-section. Its length and width are also significant, though the variation of both within a species may be surprisingly large; both these measures are to a degree proportional to the overall size of the palm and its leaf. In the key and species descriptions length is taken to be the total length of a fully expanded petiole, from point of attachment to lamina base. This should be measured on the oldest leaves at the base of the crown or, more readily, on fallen leaves. Even if it were possible to obtain a complete petiole on a leaf collected from close to the centre of the crown, observations suggest that it will not have attained its full length. Petiole width, for purposes of consistency of descriptions, is measured as close as reasonably possible of the blade, though the taper is so slight in the apical quarter of the petiole that the exact point of measurement is not critical.

The petiole transverse section (t.s.) is more or less characteristic of a species, though showing a surprising degree of variation in some species. As with width, the t.s. is taken to be that found in the apical quarter of the petiole. In the majority of species its profile is approximately plano-convex or slightly concavo-convex, though tending toward a broad-based triangle with its (abaxial) apex rounded-off. Less common is an unequally biconvex profile. There is frequently a slight adaxial keel (or less commonly 2 parallel keels), often slightly asymmetric and scarcely raised above the adaxial surface; these are possibly compression artefacts from the leaf bud. The petiole margins in t.s. vary in degree of attenuation and whether they are curved upward (i.e. giving the petiole a somewhat crescentic t.s.) or outward; in some species this character seems quite unreliable, both tendencies being observable even in the one collection. In herbarium collections there is also the problem of to what extent the t.s. shape is the result of collapse on drying; this appears to affect different species to different degrees, presumably reflecting differences in quantity and distribution of structural tissues. Degree of collapse depends also on age of leaf, the younger softer ones being more unstable in drying than the older and harder.

The petiole margin shows a number of features of taxonomic value. Most conspicuous, and traditionally regarded as most important, are the marginal prickles, found in all species on at least some leaves. These are largest and most numerous close to the petiole base but field observation has shown repeatedly that prickles are often almost entirely absent from the petioles of mature, tall plants. It is interesting to note that Cornett (1986), discussing the occurrence of petiole spines in Washingtonia filifera in California, reports that they are absent from the apical region of petioles on plants over $8 \mathrm{~m}$ tall, and almost entirely absent on plants over $14 \mathrm{~m}$. He suggests an adaptive explanation for their presence only on smaller plants, connected with the maximum reach of now-extinct herbivores of the region (Brontosaurus?!). Petiole prickles do not show very great variation between species. In some species at least some of the prickles are curved either antrorsely or retrorsely, but such character-states are not very constant. Marginal prickles grade into much smaller protuberances on petiole margins, both toward the petiole apex and interpolated between prickles. The larger of these are here termed pricklets and are usually distinctly flattened, though often irregular in shape and usually blunt. The smallest are mere pustules, detectable only as slight swellings of the margin, often of contrasting colour. Between protuberances (including prickles) the margin is apparently knife-edged to the feel. Closer examination shows it to be rounded, though with a very small radius; in some species more than others a semi-cylindrical marginal callus of distinct colour is evident.

Surfaces of the petiole exhibit some of the most taxonomically useful characters. 
For purposes of standardisation these are described for the apical region of the petiole as this part is more likely to be present in herbarium specimens. Perhaps the most obvious surface character is colour. This is usually the same on both surfaces and is most commonly green, with the depth of colour and any glaucousness similar to that of the leaf blade. Some species, though, develop a strong pinkish or red-brown colour, though only as the leaves age and probably only in conditions of strong light. Towards the petiole base there are often areas of much stronger red-brown or purplish coloration, seen in most species but especially prominent in some (e.g. L. drudei). Colour may be modified by indumentum, which is discussed below.

Pitting of the petiole surface provides interesting characters. In some species pits appear to be shallowly impressed into otherwise smooth surfaces, possibly caused by scales being pressed into the soft surface while the leaves are furled tightly in bud. Patterns of pitting vary greatly on different parts of the petiole and between upper and lower surfaces, with longitudinal zones of more prominent pitting often evident. A particular type of pitting may appear characteristic of a species but is absent from one or two collections.

Closely associated with pits on the petiole is the characteristic indumentum. In all Livistonas this has as its fundamental unit a peltate scale, but in a wide variety of forms. The scale is attached to the surface by a basal-cell mass, a dense mass of granular, usually tanniniferous cells which persists long after the scale itself has been eroded away; it appears then as a (usually) brown dot or streak on the petiole, varying much in size and degree of protrusion, from minute and virtually flush with the surface, to a prominent dark brown pustule. The scales themselves vary from membranous to thick, and in overall outline from almost circular to very elongated; they are usually asymmetrically attached, longer toward the petiole apex, and consist of sinuously radiating, narrow, colourless cells which may be dotted sparsely to densely with minute tannin-bodies giving them a brown coloration. Their margins are raggedly denticulate to deeply laciniate, sometimes divided right to the base. The laciniae are often branched and frequently become tightly twisted and tangled with laciniae of adjacent scales, giving rise to a shaggy tomentum. On young leaves just emerging from the bud the scales are often seen to be neatly seated in pits, in some species characteristically in longitudinal rows in much elongated pits; this arrangement persists in species with thick, persistent, non-laciniate scales, e.g. L. muelleri and L. decipiens, but in other species with caducous or laciniate scales their association with pits is less obvious.

Distribution and size of scales varies considerably between upper and lower petiole surface, from base to apex of petiole, and from marginal to medial region of either surface. Scale type (as distinct from scale density or distribution) is one of the most valuable and constant taxonomic characters, but its use demands attention to leaf age; there is generally little resemblance between the petiole scales of a newly emerged leaf and the equivalent scales (as to position) of a petiole which has been exposed for several years.

The petiole scales characteristic of a species are generally also found, with certain predictable modifications, on the leaf-sheath, the lamina ribs and costa, and the rachis bracts. Hairs, as opposed to scales, appear to be confined to inflorescence axes if present at all.

\subsection{Hastula}

At its apical extremity the petiole continues uninterrupted on its abaxial surface as the costa of the lamina, though with an abrupt narrowing. On its adaxial side, though, this continuum is interrupted by the hastula, a flap of tissue (Fig. 2d) in shape and position somewhat like the ligule of a grass leaf, though doubt has been cast (Tomlinson 1990) 
on whether it is homologous with that organ - the term 'ligule' is instead used by present-day palm workers for the extension of the leaf's basal sheath opposite its junction with the petiole (used in this sense, it seems to me non-homologous with the grass ligule and should rather be termed an ocrea; and it is difficult to see why the hastula should not be homologous with the grass ligule, as some grasses have an elongated and narrowed upper sheath that is not unlike the petiole of a fan palm, and its junction with the plicate blade has a very similar conformation). The term 'hastula' was coined by L. H. Bailey (1933); earlier palm writers mostly termed it a ligule. The hastula in its shape, texture and orientation exhibits useful taxonomic characters, though again there is often a surprising degree of variation within a species. From an early stage of leaf expansion it undergoes partial necrosis and progressive attrition, so that comparisons between leaf specimens of different age can be misleading. For assessment of this, as of other leaf characters, all palm collections ideally should include a range of leaf ages from the one crown, but in practice of course their bulk militates against this ideal.

Hastula morphology can be subdivided into several elements for descriptive purposes. The line of demarcation between the upper petiole surface and the hastula is here termed the hastula base; it is asymmetric to varying degree and in shape varies from an almost straight line to a narrow $\mathbf{V}$, or commonly is in the form of an irregular $\mathbf{W}$, making the petiole apex 3-lobed. Invariably it has at least small lateral (basal) lobes, representing the turning outward of the petiole margins which are decurrent onto the margins of the lowermost lamina segments. Often there is no obvious break of surface between petiole and hastula apart from a slight to somewhat abrupt upward tilt, or there may be an abrupt convexity terminating the flat petiole surface.

The actual flap of tissue comprising the hastula is here termed the hastula rim. This is rarely seen before it has undergone partial necrosis, but when new and undamaged it is frequently several times longer than on mature leaves. At this initial stage its shape is rather indeterminate and irregular, but generally much elongated with a ragged edge. In L. decipiens it has been observed to be $15 \mathrm{~cm}$ or more long. The base of the rim is thick and leathery, but laterally and apically it is rapidly attenuated into a thin, weak membrane. Subsequent necrosis gives rise to a green inner zone, usually of even width, and a necrotic margin which varies greatly in width and the pattern of its attrition, both between and within a species, and indeed frequently between the leaves of one tree. In some species, e.g. L. australis (Fig. 2a), the hastula is commonly semicylindrical or almost cylindrical, though a wider sample may reveal this to be an ontogenetic stage. It seems clear, too, that the cylindrical form is consequent upon a leaf form in which the petiole is at near right-angles to the lamina and the segments radiate in an almost complete circle. If the angle is somewhere intermediate between 90 and 180 degrees, then the hastula frequently takes the form of a squashed cylinder, with lateral edges folded back over the petiole apex.

On the abaxial surface the petiole in all Livistona species flows smoothly into the costa, at least with respect to its keel region; the margins are abruptly narrowed. There is no evidence of the abaxial hastula (dorsal crest) found in some other coryphoid genera, except for a coloured, obscurely stepped, V-shaped mark in L. fulva, cutting across the costa at varying distance from the petiole. It may be significant that this is one of the least strongly costapalmate species.

\subsection{Lamina}

The lamina (and indeed the whole leaf) in Livistona appears to have no characters by which it can be distinguished from that of several other genera of the Livistoninae, e.g. Brahea, though a majority of species share a facies of subtle characters which may allow sterile plants to be recognised as Livistona, e.g. in collections of cultivated palms. 
Aspects of its morphology under which characters and character-states are discussed below are size, outline, undulation, division, segment shape, thickness, rib profile, colour, texture, indumentum. Also significant is the costapalmate nature of the lamina in Livistona - in effect it is not palmate in the narrowest sense, in that not all segments radiate from the petiole apex but rather some of them arise from a central rib or costa which forms a continuation of the petiole. Measurement of degree of costapalmateness is discussed below.

Lamina size is one of the most useful and easily assessed characters. As might be expected it shows a fair degree of correlation with overall size of the palm, which is to a fair degree independent of environment: adverse conditions do not give rise to a very much smaller lamina size, though often petioles are significantly shortened thus giving a more compact crown. Only one measure of lamina size is used in species descriptions, length from hastula base to leaf apex along central segments. This is most readily gauged with a tape-measure, holding one end at the hastula base and grasping a handful of the central segments which are then stretched to their maximum length against the tape. In an undamaged leaf it will always be found that the longest segments are either those closest to terminal on the costa or within 2-4 segments on either side. The chief difficulty in measuring length arises from the necrosis and subsequent attrition of the fine segment apices, more pronounced and earlier in onset in some species than in others. If at least one newly expanded lamina is available for a species, a rough extrapolation is possible for older leaves with damaged segmentapices, based on width at the point of breakage. The reason for only this one measure of size being employed is that all other possible measures appear to be correlated with it, or can be dealt with under lamina outline. It was concluded early in this study that it is quite impractical to measure lamina length as the maximum distance from apices of central (distal) segments to apices of the lowest (proximal), or most rearwardpointing segments.

Lamina length varies in Australian species from a minimum of around $0.3 \mathrm{~m}$ in L. humilis to a maximum of around $2.2 \mathrm{~m}$ in L. mariae. Within-species variation so far observed is in the range $15-35 \%$ either side of the mean. Some specimens showing a shorter lamina length have been excluded from species accounts if the collections were sterile, as juvenile leaves are generally smaller (sometimes appearing large but with segment tips less attenuated).

Lamina outline, here taken to mean the curve traced out by the segment apices together with basal gap or sinus, is not easy to assess or quantify in most species. This is due partly to the 3-dimensional shape of the lamina in most species, partly to the drying artefact of contraction as in a folding fan, which greatly widens the basal sinus of loosely pressed specimens.

There is rather little variation between species in length to width ratio of the lamina but this may be difficult to assess because of the difficulty of measuring width. Clearly, if the leaf was circular in outline the width would be twice the length as defined above. Measurement reveals that this is never the case, since there is progressive shortening of segment length from apical to basal segments. Lengths of all segments were measured on several sample leaves for of two species, L. humilis and L. lorophylla: it was found that segment length remains constant or increases slightly for the first few segments (going outward from costa position at leaf apex), then falls off in an almost linear progression to about half its maximum for the basal segments. For this purpose length was measured from the hastula for all segments, even though, strictly speaking, in costapalmate palms such as these, many of the apical segments do not actually originate from the hastula but from the costa well above the hastula.

The pattern of dissection and folding of the lamina provides a number of important characters. As illustrated by Dransfield (1977), the primary, or deepest divisions are 
along the adaxial ribs, i.e. each adaxial rib terminates at a sinus between two segments. Each segment is additionally, shallowly to deeply bifurcated, the sinus between the lobes terminating an abaxial rib.

One of the most obvious but difficult to quantify differences between species is in the depth of dissection of the lamina. L. H. Bailey proposed the concept of the palman as one means of expressing degree of dissection of a fan palm leaf. The palman is the central, undivided part of the lamina, bounded by the sinuses of the primary segments. The patterns of dissection of the mostly strongly costapalmate leaves of Livistona are such that palman dimensions are difficult to measure, and other measures of dissection have therefore been devised for this study. The degree of primary dissection has been expressed (as a percentage) by comparing the length of the free portion of a segment with its total length. Between about the second segment from the costa apex and at least the fifth segment, the ratio of total segment length to length from hastula to the intersegmental sinus remains moderately constant in any one leaf. Depth of dissection has therefore been measured on one or more of the second to fifth segments depending on which is available and relatively undamaged on a specimen. It should be regarded as a relatively crude measure, but this is acceptable when considering the variation encountered between trees and between populations. In some species the variation is considerable, though useful contrasts still show up between most species-pairs which might be confused on other characters. If anomalously low values are found for any specimen it has been reassessed for possible juvenility (see discussion of this aspect below), and if suspected to be juvenile it has been excluded.

A feature that is rare or at least poorly expressed in the Australian species is the presence of 'compound segments', consisting of groups of two or more segments in which the primary sinuses are displaced to much closer to the leaf's perimeter. In a number of the species, close examination of the smallest segments close to the base of the lamina will reveal some compound segments; in L. fulva they are often present among the medium-sized segments midway to the lamina apex, though not at all conspicuous; the same applies to some specimens of L. australis.

Depth of bifurcation of segments is expressed by comparing the length of the bifurcated portion to the free length of the segment. It is even more affected by juvenility than is depth of dissection. The majority of species have deeply bifurcated segments in the adult state, the lobes accounting for around $50 \%$ or more of the segment's free length. Only 2 species, L. muelleri and L. fulva, consistently have very shortly bifurcated segments (under $10 \%$ of free length). A remarkable feature of some specimens of L. drudei is an apparent secondary bifurcation of the lobes of up to a few centimetres (occasionally more than $10 \mathrm{~cm}$ ) in depth.

Width of segments has been taken as the maximum found on any one specimen, measured at the widest point above the intersegmental sinuses but below the point of bifurcation. This also shows considerable variation within a species, sometimes even between different leaves from the one tree, but the ranges obtained still show useful distinctions between species. Width is a maximum between about the second and fifth segments either side of costa, falling off somewhat erratically among the very apical segments, and in the opposite direction falling off toward the lamina base in a fairly regular progression.

Outline of the individual segments includes some useful characters, apart from the crude quantitative measures just discussed. In some species the free part of the segment below point of bifurcation is parallel-sided, in others it may taper slightly toward the apex, in others slightly toward the base. This tapering appears consequent upon depth of dissection since the segments of deeply dissected leaves will fit better against one another if tapered toward the base, whereas very shallowly dissected 
leaves demand a taper in the reverse direction. Tapering is not always consistent within a species. Variation is far greater in the lobes both in outline, and also in direction to a minor degree. In some species they diverge noticeably from the point of bifurcation, though this should be confirmed by pressing the segment against a flat surface. In most species the outer margins of the segments continue in a straight line and the inner margins of the lobes form a narrow $\mathbf{V}$, but in some the inner margins appear more convergent. Outline of the individual lobes varies in a number of ways: an interesting phenomenon seen on some (even most) specimens of nearly all species is a curious 'step' in either the inner or outer margins of each pair of lobes. Even in the one collection, this step can vary greatly both in presence and position between different leaves and between segments of the one leaf. When the two lobes of a segment are folded together, as in bud, the steps coincide perfectly. This, combined with its erratic occurrence, suggests that it is in a sense an 'artefact' of compression of the leaves against one another in bud, and is of doubtful taxonomic value.

Apices of the lobes vary greatly in their degree of attenuation, some being finely aristate or even hairlike, others tapering evenly to a fine or more abrupt point. Usually the lower, narrower segments (closest to petiole) have more finely attenuate lobes, but for purposes of standardising descriptions only those of the upper, broader segments are considered. Considerable variation is also found in degree of necrosis, brittleness, and consequent attrition of apices and the earliness of its onset in relation to leaf expansion. This pattern appears characteristic of a species.

A distinctive feature of many fan-palm leaves is the presence of thread-like appendages in the intersegmental sinuses, terminating the adaxial ribs. Attention has been drawn to these by morphologists such as Eames (1953) and their relationship to the development of plications in the leaf primordium explained. They are evident in nearly all the Livistona species examined, but vary in thickness, texture, indumentum and persistence. Their length is initially indefinite (up to a maximum of the total lamina length) but their early necrosis and consequent brittleness results in short remnants only being found on fully expanded leaves. Nonetheless each species seems to retain a characteristic length of appendage, within rather broad limits. In the light of the explanations of their origin it is hard to see why they do not occur also in the sinuses between the segment lobes, terminating the abaxial ribs, but this does not appear to be the case.

Another major aspect of the overall plan of the leaf, so far hardly considered, is the degree to which it is costapalmate. The costa is most evident on the abaxial surface because it is roughly triangular in transverse section, displaying a broad face on the abaxial leaf surface. Many of the lower segments join the margins of the petiole apex rather than the costa but there is no point at which it is possible to say that one segment arises from the petiole apex but the next, more distal segment arises from the costa. There is progressive stretching apically of the costal 'internodes', or intervals between the points of attachment of segment midribs. Toward the costa apex the final 2-4 'nodes' are widely but often rather unevenly spaced and the costa finally terminates in a sinus between the two co-apical segments, which are sometimes of greatly reduced width and irregularly formed compared with the third to fifth segments out from the co-apical ones. The position of this uppermost sinus relative to total lamina length is found to be quite erratic on leaves from the one tree, leading to the conclusion that overall costa length as a proportion of lamina length is not a very useful taxonomic character. Since the great majority of segments in all species join the costa/petiole-apex in the basal 10\% of total lamina length, a more useful measure of costapalmateness is given by the proportion of all segments which join it beyond that region. This proportion (expressed as a percentage) was calculated for three representative specimens of each species (Table 2 ). 
Table 2. Leaf laminae of Livistona species

\begin{tabular}{|c|c|c|c|c|}
\hline Collection & $\begin{array}{l}\text { Lamina } \\
\text { length } \\
\text { in } \mathrm{cm}\end{array}$ & $\begin{array}{l}\text { Total no. of } \\
\text { segments }\end{array}$ & $\begin{array}{l}\text { No. arising } \\
\text { above basal } \\
10 \% \text { of } \\
\text { lamina length }\end{array}$ & $\begin{array}{l}\text { Percentage } \\
\text { arising } \\
\text { above } \\
\text { basal } 10 \%\end{array}$ \\
\hline \multicolumn{5}{|c|}{ L. mariae subsp. mariae } \\
\hline Rodd 3215 & 218 & 86 & 13 & 15.1 \\
\hline \multicolumn{5}{|c|}{ L. mariae subsp. occidentalis } \\
\hline Rodd 2868 & 176 & 79 & 18 & 22.8 \\
\hline \multicolumn{5}{|c|}{ L. mariae subsp. rigida } \\
\hline Rodd 2937 & 161 & 84 & 15 & 17.9 \\
\hline \multicolumn{5}{|l|}{ L. lanuginosa } \\
\hline Rodd 3759 & 129 & 90 & 15 & 16.7 \\
\hline $\begin{array}{l}\text { Irvine } 1912 \\
\text { leaf } 1\end{array}$ & 188 & 87 & 19 & 21.8 \\
\hline $\begin{array}{l}\text { Irvine } 1912 \\
\text { leaf } 2\end{array}$ & 163 & 87 & 15 & 17.2 \\
\hline \multicolumn{5}{|l|}{ L. benthamii } \\
\hline Specht 1187 & 96 & 77 & 12 & 15.6 \\
\hline Jacobs $1790 *$ & 87 & 70 & 7 & 10.0 \\
\hline Rodd 2904 & 81 & 59 & 12 & 20.3 \\
\hline \multicolumn{5}{|l|}{ L. drudei } \\
\hline $\begin{array}{l}\text { Rodd } 3135 \\
\text { leaf } 1\end{array}$ & $140+20$ & 66 & 15 & 22.7 \\
\hline $\begin{array}{l}\text { Rodd } 3135 \\
\text { leaf } 2\end{array}$ & $150+10$ & 69 & 12 & 17.4 \\
\hline Irvine $1832^{*}$ & 125 & 71 & 9 & 12.7 \\
\hline Irvine $1833^{*}$ & 100 & 68 & 9 & 13.2 \\
\hline \multicolumn{5}{|l|}{ L. australis } \\
\hline $\begin{array}{l}\text { Rodd s.n., } \\
\text { 28.viii } 75\end{array}$ & 27 & 87 & 10 & 11.5 \\
\hline Rodd 3615 & 121 & 85 & 9 & 10.6 \\
\hline Irvine 1928 & 30 & 83 & 8 & 9.6 \\
\hline \multicolumn{5}{|l|}{ L. nitida } \\
\hline Rodd 3055 & 177 & 76 & 11 & 14.5 \\
\hline Rodd 3051 & 173 & 71 & 9 & 12.7 \\
\hline Telford 5648* & 105 & 69 & 11 & 15.9 \\
\hline \multicolumn{5}{|l|}{ L. decipiens } \\
\hline Rodd 3045 & 185 & 69 & 15 & 21.7 \\
\hline Rodd 3117 & c. 180 & 80 & 18 & 22.5 \\
\hline Rodd 3069 & 165 & 81 & 13 & 16.1 \\
\hline \multicolumn{5}{|l|}{ L. fulva } \\
\hline Rodd 1166 & 87 & 64 & 3 & 4.7 \\
\hline Rodd 3062 & 93 & 63 & 4 & 6.3 \\
\hline Rodd 3063 & 99 & $30^{*}$ & $2^{*}$ & 6.7 \\
\hline
\end{tabular}




\begin{tabular}{|c|c|c|c|c|}
\hline Collection & $\begin{array}{l}\text { Lamina } \\
\text { length } \\
\text { in } \mathrm{cm}\end{array}$ & $\begin{array}{l}\text { Total no. of } \\
\text { segments }\end{array}$ & $\begin{array}{l}\text { No. arising } \\
\text { above basal } \\
10 \% \text { of } \\
\text { lamina length }\end{array}$ & $\begin{array}{l}\text { Percentage } \\
\text { arising } \\
\text { above } \\
\text { basal } 10 \%\end{array}$ \\
\hline \multicolumn{5}{|l|}{ L. muelleri } \\
\hline Hind 748 & 70 & 56 & 1 & 1.8 \\
\hline Hind 216 & 70 & 60 & 2 & 3.3 \\
\hline Rodd 3170 & 71 & 58 & 3 & 5.2 \\
\hline $\begin{array}{l}\text { Rodd } 3159 \\
\text { leaf } 1\end{array}$ & 70 & 55 & 1 & 1.8 \\
\hline $\begin{array}{l}\text { Rodd } 3159 \\
\text { leaf } 2\end{array}$ & 71 & 58 & 3 & 5.2 \\
\hline \multicolumn{5}{|l|}{ L. humilis } \\
\hline Benson 950 & 47 & 32 & 3 & 9.4 \\
\hline Gittins 2646 & 48 & 31 & 4 & 12.9 \\
\hline Rodd 2926 & 37 & 32 & 4 & 12.5 \\
\hline \multicolumn{5}{|l|}{ L. eastonii } \\
\hline Maconochie $1228^{*}$ & 59 & 41 & 8 & 19.5 \\
\hline Symon 10254 & 78 & 54 & 10 & 18.5 \\
\hline Rodd 2887 & 81 & 45 & 9 & 20.0 \\
\hline \multicolumn{5}{|l|}{ L. alfredii } \\
\hline Rodd 2847 & 103 & 60 & 14 & 23.3 \\
\hline Rodd 2848 & 130 & $28^{*}$ & $5^{*}$ & 17.8 \\
\hline Wark A & 122 & 63 & 7 & 11.1 \\
\hline \multicolumn{5}{|l|}{ L. victoriae } \\
\hline $\begin{array}{l}\text { Rodd } 2934 \\
\text { leaf } 1\end{array}$ & 112 & 53 & 9 & 17.0 \\
\hline $\begin{array}{l}\text { Rodd } 2934 \\
\text { leaf } 2\end{array}$ & 107 & 52 & 10 & 19.2 \\
\hline Rodd 2800* & 74 & 47 & 5 & 10. 2 \\
\hline Parker $1065^{\star}$ & 66 & 41 & 5 & 12.2 \\
\hline \multicolumn{5}{|l|}{ L. kimberleyana } \\
\hline Symon 10154* & 66 & 44 & 8 & 18.2 \\
\hline $\begin{array}{l}\text { Rodd } 2866 \\
\text { leaf } 1\end{array}$ & 92 & 40 & 7 & 17.5 \\
\hline $\begin{array}{l}\text { Rodd } 2866 \\
\text { leaf } 2\end{array}$ & 99 & 43 & 9 & 20.9 \\
\hline \multicolumn{5}{|l|}{ L. lorophylla } \\
\hline Kenneally 2162 & 84 & 44 & 12 & 27.3 \\
\hline Telford 6404 & 68 & 48 & 9 & 18.7 \\
\hline Rodd 2871 & 93 & 35 & 8 & 22.9 \\
\hline \multicolumn{5}{|l|}{ L. inermis } \\
\hline Telford 8114 & 38 & 44 & 6 & 13.6 \\
\hline Telford 8064 & 48 & 33 & 1 & 3.0 \\
\hline Benson 952 & 43 & 42 & 4 & 9.5 \\
\hline Symon 10347 & 34 & 38 & 3 & 7.9 \\
\hline
\end{tabular}


Table 2 shows that this measure of costapalmateness varies within a fairly narrow range for all the Australian species. Although the minimum value found was $1.8 \%$ (some plants of L. muelleri ), most of the collections of all but two species showed values in the range $8-25 \%$. Thus, the degree of costapalmateness among the Australian species is all of a similar order, and this is borne out by a careful subjective assessment.

A few species, e.g. L. decipiens, appear superficially to be very strongly costapalmate, but this is an illusion caused by the very deep dissection of the lamina, which serves to emphasise the costal region. It is also evident that the measure of costapalmateness shows large variation within a species. Some of this variation is due to operation of chance factors, exaggerated by the very small sample surveyed. If, for example, the value were based on only three or four segments out of 30, then one less (which may just miss being included) will cause a major increase in the value; sometimes two segments, one each side of the costa, both barely fall outside the basal zone.

Degree of costapalmateness is nonetheless shown to be quantifiable by this measure. The lamina is here described as weakly, moderately, or strongly costapalmate, depending on whether respectively $0-7 \%, 7-16 \%$, or over $16 \%$ of its segments join the costa beyond its basal $10 \%$ zone. These boundaries are chosen to give the most useful discrimination between species. By this criterion L. muelleri and L. fulva are weakly costapalmate; L. humilis, L. australis and L. nitida are moderately costapalmate; and L. eastonii, L. kimberleyana and L. lorophylla are strongly costapalmate. Other species can be described as weakly to moderately, or moderately to strongly costapalmate.

Another lamina character which emerges in Table 2 is number of segments in the lamina. It will be seen that this is reasonably constant for each species, except where juvenility is suspected, and thus appears taxonomically useful. It is not always easy to count accurately, in that the basal segments are sometimes of irregular width, suggesting that some may be fused together, or are sometimes vestigial. There are sometimes also one or two vestigial apical segments. However, an error in counting of $\pm 5 \%$ is regarded as acceptable for purposes of description.

One of the most striking characteristics of the fresh whole leaf in most of the Australian species is the pattern of undulation of the lamina. This takes the form of undulations, which are best seen in a tangential cross-section of the lamina at rightangles to all the segments (e.g., by cutting a small circle out of the centre of a fresh leaf). Both number of undulations and their amplitude vary between species, and amplitude also varies between collections of a species depending on both maturity and exposure. The most extreme undulations are on very mature palms in the most exposed, sunny places. Invariably there is a median trough along the costa (viewed from above), which in most species is gently to strongly downward-curving (Fig. 9a), adding a further dimension to undulation of the lamina. On either side of the trough there are one to three crests of undulations, referred to in the descriptions as 'adaxial undulations'. Approaching the basal margins of the lamina the undulations become tighter and usually the margins are sharply inflexed or involute, so that some basal segments are resupinate. In several species there is an additional, very tight fold of the last two to three segments back in the other direction, i.e., the resupination is reversed by a double fold. The spatial relationship of these basal folds with the petiole apex and hastula is complex, and their morphogenesis is almost impossible to visualise. To speculate on the adaptive value of undulation, its exaggeration under exposed, high light conditions makes it likely that it is a means of reducing absorption of solar radiation, and possibly also of strengthening the lamina against wind damage. There is some degree of correlation between lamina size and degree of undulation.

Another feature which affects the three-dimensional shape of the leaf in the palm crown is drooping of the segments. In some species, most notably L. decipiens and 
L. australis, the segment lobes all hang vertically, undergoing a moderately sharp bend just above the point of bifurcation. This would appear to be the result of three characteristics of such leaves: (1) very long lobes; (2) thin lamina texture, lacking mechanical strength; and (3) the V-shaped section of the segment below the point of bifurcation, imparting mechanical strength in this region. Most other species have the segment lobes drooping to some lesser degree, but a few, most notably L. muelleri, have segments which are stiff and straight for their whole length; this correlates with very short segment lobes.

The ribs of the lamina present a number of characters, chiefly in their cross-sectional shape and dimensions. In most species they are roughly rectangular in t.s., between 1.5 and $5 \mathrm{~mm}$ deep and 0.5 to $1.5 \mathrm{~mm}$ wide. Generally the abaxial ribs are slightly larger in t.s. than the adaxial, though this is not always the case. The summit of a rib is usually squared off more or less sharply, but often one edge is more rounded than the other. In some species the ribs are more elliptical in t.s., or subtrapeziform, with the narrower dimension adjacent to the leaf surface. The measurements in descriptions are expressed as depth, which is to be taken as the amount by which the rib stands above the leaf surface, and width, which is the greatest width. These have been measured with a dial caliper on dried specimens, at approximately their mid-points (which are much closer to the hastula on the adaxial ribs), choosing the more robust ribs on any one lamina.

Lamina thickness was also measured with a dial caliper, and shows less variation between species and more within a species than might be expected, given the differences in rigidity that are readily perceived. It may be that rigidity of the lamina derives largely from the ribs. The greatest thickness found was $0.45 \mathrm{~mm}$, the least around $0.15 \mathrm{~mm}$, though on a given leaf measurement of thickness was found to be repeatable only to around $0.05 \mathrm{~mm}$. Measurement was standardised at a cut end about halfway between base and apex, with the narrow blades of the caliper paralleling and between major veins which are slightly thickened. Care was taken to avoid excessive pressure on the blades. Surprisingly little difference in thickness was found between fresh and dried leaves when both were available. Variation between different parts of the one leaf was slight, except that there was detected a tendency for thickness to increase somewhat towards the lobe apices.

Leaf indumentum is of great importance. The Australian species exhibit a great diversity of indumentum type, with sometimes more than one type present on a leaf, as well as great variation in density and distribution over the various parts of a leaf. Two main classes of indumentum can be recognised: (a) narrow chaffy scales ('ramenta'), and (b) sessile, more or less disc-like, closely appressed peltate scales, often sunken in elongated pits. Scales of the first type are mostly shed or wear off as the leaf ages, especially on the lamina, and it is on the petioles and basal parts of the costa and ribs, mainly on the abaxial surface, that they are densest and most persistent. The sessile scales of the second type are attached more securely and are more or less identical to the scales of the upper petioles, under which heading ( 2.2 above $)$ their morphology is discussed.

The nature of the cuticle and associated surface layers of wax on the leaf lamina are significant. The species with very thick-textured, xeromorphic, bluish or greyish leaves, e.g. L. alfredii and L. eastonii, seem to have the cuticle impregnated with wax which is not readily rubbed off. Other species, e.g. L. mariae and L. lanuginosa, have a very thick but soft layer of wax which seems quite distinct from the cuticle and easily rubbed off; it is usually most noticeable on the abaxial surface, but a thinner almost transparent layer may also be present on the adaxial surface. In some species the wax layer is very thin and only detectable on the undersurface of newer leaves, e.g. L. muelleri and L. fulva. Most species of more mesic environments, e.g. L. benthamii, 
L. drudei and L. australis, have no detectable glaucousness of the leaves, the surfaces being deep green or brownish green and more or less glossy.

Venation of the lamina is of limited use as a key character but does show a characteristic range for each species. Each intercostal area of lamina has longitudinal veins of several orders of prominence in an alternating sequence (see anatomical diagrams). The prominence of these veins and their spacing varies within fairly narrow limits, with the least prominent in those species with xeromorphic, very opaque leaves. The number of prominent veins which can be counted across a halfsegment (interval between an adaxial and abaxial rib) varies between certain limits for each species, but the overlap between species is so large that it is rarely of use as a distinguishing character.

The longitudinal veins are invariably connected at regular intervals by transverse veinlets ('commisures') which show varying degrees of irregularity in length, orientation and curvature. In relation to the longitudinal veins some are steeply oblique (though direction of slope may frequently reverse), others almost at right angles. A veinlet may bridge the interval between adjacent prominent longitudinal veins, or may pass beneath two or more such veins, sometimes crossing nearly all the longitudinal veins in a half-segment. They may be virtually straight or are often curved into a slight S-bend (sigmoid); in longer veins the S-bends may combine to give a wiggling form. Like the longitudinal veins, the transverse veinlets are most prominent in the species with thin-textured, deep green leaves, where there often show up strongly by their whitish colour and translucency. Unfortunately their appearance in the fresh leaf has not been consistently recorded.

In transverse section (Fig. 3, 4) there are consistent differences in the shape and distance between major vascular bundles; continuity and number of layers of the hypodermis of upper and lower surfaces and presence of buttresses of the hypodermis extending to the major vascular bundles; and the shape, size and distribution of the fibre strands.

\section{Inflorescence}

Inflorescences nearly always appear several in the palm crown at the one time, among the bases of living leaves. In all Australian Livistona species, as in most coryphoid palms, the flowering and fruiting cycle is completed, while the subtending leaves of inflorescences are still close to the centre of the crown, and the leaves remain alive long after the inflorescences have fallen (unless fire-killed); thus the inflorescences at all stages are intrafoliar rather than infrafoliar. Inflorescence length as an absolute measure varies considerably in most species, and for purposes of characterising the species is best measured by relating it to leaf length, e.g. shorter than petiole; exceeding petiole but shorter than lamina; and so on. Inflorescence attitude is of some significance, though this changes from earliest to later anthesis and even more so between anthesis and fruiting, when weight of fruit results in most inflorescences being pendulous.

The basic pattern of inflorescence architecture in Livistona is one with an elongated first-order axis (counting trunk as zero-order, as in Tomlinson \& Soderholm 1975) which is dominant over a number of equally spaced, more or less evenly sized, second-order branch systems (Fig. 2c). These branch systems, together with the similar branch-system terminating the first-order axis, are here termed partial inflorescences, and there may be as many as 15 partial inflorescences in one inflorescence. When a whole inflorescence is dissected they are found to be arranged in a secund-distichous orientation. The first-order axis, or rachis is roughly triangular in section with a rounded adaxial side and two abaxial faces, from which the second-order axes branch alternately. 
This variation from a strictly spiral phyllotactic arrangement is similar to that described by Tomlinson and Moore (1968) in first-order branches of Nannorrhops inflorescences, a variation that they ascribe to the 'requirements of available space' such that 'any inherent phyllotactic arrangement is suppressed'. They also note that there is a gradual change from distichous to spiral arrangement of second-order branches toward the distal ends of the first-order branch, though the spiral is often obscure. A similar change has also been observed in all Livistona inflorescences examined.

In all but three, or possibly four, of the Australian species the inflorescence conforms to the pattern described above, and it seems reasonable to assume this represents the primitive state for the genus. One departure from the pattern is found in L. inermis; in this species there is a reduction in the number of partial inflorescences accompanied by enlargement of the basal one to a size subequal to the remainder of the inflorescence, resulting in a very short and broad inflorescence (Fig. 20d); this state is also referred to by Uhl and Dransfield (1987, p. 17) for the non Australian L. woodfordii and L. rotundifolia (neither of which appears to have a close relationship to L. inermis) Another departure is suppression of lower branches on an axis, seen in an extreme form in L. humilis (Fig. 13c), in which the rachis is long and cane-like with up to 8 lower nodes bearing sterile bracts only, i.e. with no lateral partial inflorescences, so that in effect only the terminal partial inflorescence remains. This form of inflorescence occurs only on fruit-bearing plants of L. humilis, in contrast to the functionally male plants which have the conventional inflorescence structure for the genus.

Of significance in distinguishing species is the number of further orders of branching in the partial inflorescences: this varies from 2 in L. benthamii to a maximum of 5 (usually 4) in L. australis, though the highest number for each species is usually found only on one or two of the major branches of the lowest partial inflorescence. In the species descriptions this is expressed in the style 'partial inflorescence ... branched to $n$ further orders...', but the total number of orders of branching is then $n+2$ if the palm trunk is treated as the zero-order axis.

What appear superficially to be the ultimate, flower-bearing branches, i.e. the rachillae, are slender and spiciform and mostly over $2 \mathrm{~cm}$ long; but, more evidently in some species than others, close examination reveals that the flowers themselves are borne in clusters, the axis of each cluster representing a further order of extremely condensed branches, in some cases approaching zero in length and reduced to the merest knob on the apparent rachilla (which is, in fact, hereafter termed the rachilla, following the normal convention in palm descriptions). In some species these ultimate axes, hereafter referred to as the cluster axes, mostly bear only a single flower, but there is always some proportion of them bearing 2 or more flowers. The size, shape and other features of the cluster axes are of considerable taxonomic significance, as are also the number of flowers per cluster (expressed as a range), and the width of spacing of clusters of along the rachis in some cases.

Together with their flowers, the cluster axes are referred to as cincinni by Uhl and Dransfield (1987), who refer (p. 19) to Uhl (1969) in which developmental studies were used to demonstrate the sympodial nature of apparently equivalent structures in another Coryphoid genus, Nannorrhops. In some Australian Livistona species, however (for example L. decipiens - Fig. 11), the cluster axes can be quite elongated and even appear at times to grade into the rachillae, which may call into question their sympodial nature. Other species, though, exhibit a constant sessile flower cluster resembling that illustrated by Uhl \& Dransfield (p. 192) for L. chinensis, while L. mariae has flowers arranged secundly on the outer face of a sharply deflexed and flattened cluster axis, appressed against the rachilla; this arrangement (Fig. 6) superficially resembles the acervulus of some Hyophorbeae as described by Uhl and Dransfield (p. 21) except that the cluster axis is not adnate to the rachilla. 
Several characters of the rachillae are useful in discriminating species, notably their length (expressed as a range), thickness (though accrescence in fruit must be kept in mind), colour, features such as wrinkles or striation, and indumentum. With regard to the last, it seems a common feature of inflorescence axes, in contrast to bracts, to be quite glabrous and indeed the scales characteristic of foliar structures are absent from all such axes. But in a minority of species the axes are noticeably papillose, and in a very few they are very shortly pubescent (e.g. L. humilis). The degree of papillosity or pubescence is usually greater on the rachillae than on thicker axes.

Of importance in interpretation of Livistona inflorescences are the bracts. As leafhomologues, they share the general palm character of being closed, i.e. tubular, though this is not obvious when the bracts are much reduced. The inflorescence rachis at least bears well developed tubular bracts which overlap one another (Fig. 2c). The lowermost bract on each axis is the prophyll, identifiable by its adaxially displaced two keels, as well as by its position and the fact that it is empty, i.e. does not subtend a branch. The prophyll of the primary axis resembles the other tubular bracts except that it is usually shorter and thicker in texture. In most Australian Livistona species there are no empty peduncular bracts apart from the prophyll: the exceptions are the 'male' inflorescences of L. humilis (noted above) with up to 8 tightly overlapping empty bracts. Apart from the prophyll, the other bracts clothing the primary axis, termed rachis bracts following Uhl and Dransfield, are also 2-keeled but with keels fully opposite one another and less prominent, sometimes barely detectable. The rachis bracts of most species are 2-lipped at the mouth with identical lips positioned dorsally and ventrally, at least on the distichous part of the axis, and two laterally positioned keels each terminating in acute sinuses between the lips. The lip apices are generally acute or acuminate, though often torn. The rachis bract apices of L. fulva are exceptional, irregularly laciniate with several to many points of equal length; it is difficult to detect whether these result from tearing of the bract apex, or are a normal morphogenetic feature.

The character of the rachis bracts is strongly influenced by their texture and by the tightness with which they sheathe the axis. Aspects of texture are thickness, rigidity (proportion of mechanical tissues to parenchyma), fissility, and earliness or lateness of tissue necrosis. Three extremes are exemplified in the following species: (1) L. mariae - bracts tightly sheathing, thick, moderately rigid, hardly splitting, remaining green at least to early fruit (except at apices); (2) L. alfredii, L. victoriae - bracts loosely sheathing, thick and very rigid, usually much buckled with irregular splits and tears, tissues dead by anthesis; (3) L. benthamii - bracts tightly sheathing, thin, smooth and straight, remaining green at least in lower part up to about anthesis.

Prophylls of the primary branches (partial inflorescences) are themselves tightly enclosed within the rachis bracts, with only their upper parts protruding. In texture, colour, indumentum and shape of apices they resemble closely the rachis bracts. Progressing further outward through the orders of branches there is a rapid reduction in bract size and complexity, so that the bracts subtending the rachillae are small, triangular, membranous organs with no apparent tubular base. The flower clusters have even smaller subtending bracts, termed here the cluster-bracts - usually displaced to one side. Their proper shape is usually only discernible pre-anthesis, as they rapidly shrivel and disappear leaving only a basal rim that is often barely detectable by the time of early fruit development. The bracteoles associated with individual flowers of a cluster are often more difficult to detect and even more difficult to assign to a particular flower in the cluster, such is the degree of displacement they appear to have undergone. In the relatively few collections in which bud-stage inflorescences are available, both cluster-bracts and bracteoles are seen to be very delicate and membranous, with the apex drawn out into a fine hairlike point, and in 
some cases apparently laciniate. Because of their absence or vestigial presence in most available collections, they are not useful in distinguishing species.

\section{Flower}

Flower structure is fairly uniform in the Australian species and conforms to the general pattern found in most of the 12 genera of Livistoninae (see Uhl \& Dransfield 1987). Overall shape of the flower is noted in the descriptions, e.g. funnel-shaped, cupshaped, rotate, but these should be interpreted with some caution as it is possible they change between the late pre-anthesis and early post-anthesis stages and, given the paucity of flowering collections of most species, it has not been possible to compare these stages. Overall length of flower may also be of value, though only within broad limits; it has been found to vary by as much as $150 \%$ (minimum to maximum) in species for which a number of flowering collections were available. In the case of rotate flowers, length was measured from the very base of the flower along the back of a petal to its apex.

The calyx is always much shorter than the corolla, and the sepals much thinner than the petals; at the base they are fused into a shallow cup. The base of the calyx runs into a stalk-like structure, up to about $1 \mathrm{~mm}$ long in some species, which is sharply constricted at the point where it attaches to a projection of the cluster axis. This is always the point of abscission when unfertilised flowers are shed. The stalk-like structure is here termed the anthopodium following Briggs and Johnson (1979), who define it as the internode between the flower and the most distal node below the flower. Since 'pedicel', as used by Uhl and Dransfield (1987), is described as sometimes bearing prophylls, it does not always equate with pedicel, and anthopodium is the more precise term. The base of the anthopodium is generally trigonous and concave in Australian Livistona species, the angles corresponding to the bases of the sepals (Fig. 12). Its junction with the cluster axis (or a minute projection thereof) is usually very constricted, concealed beneath its concave base.

The valvate petals are nearly always thickened at their edges and apices and are often somewhat cymbiform. A distinctive feature is the 'sculpting' of their inner faces, usually with 2 longitudinal ridges which separate 3 concave depressions, the median one of which may extend as a hollow under the thickened apex. There would seem to be a correspondence between the petal concavities and the stamens, suggesting that they result from tight packing of the flower parts in early bud stage, though differential expansion usually results in the petal concavities being much larger than the anther locules. They are rather too constant a feature to be of much taxonomic value, and such variability as they do show seems to be strongly correlated with petal thickness. A feature of the petals that does not appear to have been reported previously is their basal auricles, present to at least some degree on nearly all species examined. They are not truly basal, since they arise just above the point of fusion of the petal bases, in the inter-petal sinuses. These auricles are not obvious, being mostly membranous and tightly overlapping with those of adjacent petals, and usually need prising apart with a fine needle before they become visible. The species in which they are most readily seen is L. inermis (Fig. 21). Their direction varies from retrorse, i.e. giving the free part of the petal a sagittate outline, to laterally diverging, and their outline from acute-triangular to broadly rounded; they are commonly larger on one side of the petal than on the other.

The stamens show few distinctive characters apart from the dimensions of their filaments and anthers. The short, flattened filaments are both connate basally for up to half their length and adnate to the petals for about the same amount; they are rather abruptly acuminate at the apex, and show some variation between species in the 
degree of angularity or 'shouldering' at the point where they start to narrow - the term shouldered has been used where this angularity is well developed, e.g. in L. humilis (Fig. 14); in contrast, a species with unshouldered filaments is L. australis (Fig. 10). Stamen length within a species appears to vary with petal length, so it seemed most appropriate to express it as a proportion (expressed here as a fraction, e.g. $4 / 5$ ) of petal length, both measured in an opened-out flower from the base of the petal tube. The range among the Australian species is not large, between $3 / 5$ and $\% / 10$, and this character may not be very significant. And finally there is anther size, expressed here only as length since their shape is fairly uniform: in most species the anthers are around $0.4 \mathrm{~mm}$ long, but those of L. lorophylla examined were only $0.2 \mathrm{~mm}$, and at the other extreme L. australis anthers were $0.5-0.7 \mathrm{~mm}$ long - this is also the largestflowered of the Australian species.

The carpels likewise show few distinctive characters at specific level. As with the stamens, it seemed most appropriate to describe their size in relative terms, in this case as a proportion of stamen length. Some differences were observed in shape of the ovary portion, in style length and in the abruptness or otherwise of the carpel's constriction into the style.

\section{Fruit}

The fruits of Australian Livistona species are of rather uniform type, but they provide a rich suite of taxonomic characters. Fruit size varies considerably, with diameter as small as $8 \mathrm{~mm}$ in ripe fruit of L. humilis, to as large as $35 \mathrm{~mm}$ in L. lanuginosa and L. alfredii. Variation is considerable between individuals of a species, for example 13-22 mm in L. australis, but fruit size is still a useful diagnostic character for some species. Fruit shape in the majority of species is globose, the main exceptions being the shortly ellipsoid or obovoid fruits of some of the more slender northern species, viz. L. humilis, L. inermis, L. eastonii, L. lorophylla and L. kimberleyana. Fruits of some other species, viz. L. benthamii, L. drudei, L. muelleri, are somewhat pyriform. A frequent feature is a slight flattening of the ventral (adaxial) side of the fruit, corresponding to the base of the seed coat intrusion into the endosperm, with the result that the diameter measured dorsiventrally is slightly less than the diameter in the lateral plane. In some species the ventral suture is evident in the form of a slight crease even in the ripe fruit; less common is an apical mucro (ventrally displaced to varying degree) representing the stigma. In common with most other tricarpellate, apocarpous genera Livistona normally aborts 2 of the carpels at an early stage, and their vestiges may sometimes be observed at the base of the fruit. A search among large numbers of fallen fruit will sometimes turn up the odd one in which 2 , or in very rare cases all 3 , of the carpels have developed, joined together at the base only, though it is more common to find the additional carpels have developed only partially, their enlargement evidently suppressed at an intermediate stage of growth. It is very doubtful that such aberrant fruits have any taxonomic significance at species level.

The stalk of the mature fruit is more complex in structure than may appear at first glance. In most species it is a compound structure consisting of three main elements, all undergoing considerable enlargement post-anthesis. The calyx is persistent, sometimes remaining attached to fallen fruits; between the calyx and fruit base there is usually a fleshy pad of tissue representing the expanded remnants of the fused petals and filaments. Below the calyx, the anthopodium also enlarges greatly, especially in diameter, with its lower rim swelling downward to overlap and press hard against the similarly enlarged but slightly more woody cluster axis. It is very rare for more than one fruit to develop from the flowers of each cluster, hence the cluster axis appears part of a single fruit stalk; and in fact only a small minority of the clusters 
on a rachilla ever bear a fruit. The compound fruit stalk is commonly up to double the length of its combined elements at anthesis.

Colour of the ripe fruits appears to be predominantly black or brownish-black in Australian Livistona. The china-blue colour seen in some Asiatic species such as L. chinensis or L. saribus does not occur, nor the bright red of (immature?) L. rotundifolia. The ripe colour of some of the northern species is not yet known with certainty, in particular that of L. victoriae, of which only immature or very old fallen fruits have been collected, all of which are brown, though the label notes of one collection suggest they may ripen to black. Other surface characters of the epicarp may be significant, for example presence or absence of a glaucous bloom, a high gloss as a opposed to a matt surface (usually minutely wrinkled), and the presence in some species of small corky dots or pore-like structures (apparently confined to the larger-fruited species). There is some variation in epicarp texture, some species having very thin, delicate skin while in others it is thicker and tougher.

The mesocarp exhibits a range of useful features. Generally the fresh colour and texture have not been recorded, though there is a strong suggestion that species fall into two broad classes of 'thick and juicy' and 'thin and fatty' (but with some intermediate). Characters that are well preserved in the dry state include the abundance, size and arrangement of fibres or stone-cells; presence/abundance of reddish-brown tannin-bodies (possibly an artefact of drying); and texture, colour and/or patterning of inner face of mesocarp. Thickness of mesocarp in the dry state has been measured for each species and appears constant within certain limits.

The endocarp of most Livistona species is straw-coloured, thin, brittle and somewhat granular in texture, but in a few species it is somewhat tougher with a springy texture. There is some variation in the degree to which it remains adherent to the mesocarp after ripening and drying. When examined under magnification its inner or surface may show some patterning, which in a few cases seems to be characteristic of a species, though there is a tendency for the any patterning of the inner surface to reflect that of the seed surface. Endocarp thickness has been measured for all species of which ripe fruit was available.

\section{Seed}

Seed morphology has been much emphasised by past workers, though the basic structure of the seed is remarkably uniform in Australian Livistona. Its shape varies from subspherical, usually somewhat flattened at the base of the seed coat intrusion, to moderately ellipsoid in those species with elongated fruit, though the length:diameter ratio is never more than 1.5:1. The hilum and raphe are inconspicuous in all but the largest-fruited species, but in nearly all species there is a more or less circular patch on the ventral side that is shinier and darker brown than the rest of the seed surface - this corresponds to the base of the intrusion of dark-coloured seed coat into the whitish endosperm, which characteristically takes the form of a cylinder expanded to varying degree at its apex into a somewhat fungoid shape, and always lying directly opposite the embryo position (Fig. 2a). The shape, size and orientation of the intrusion can only be discovered by splitting or cutting the seed in both transverse and longitudinal planes, the latter through the embryo position. Because of the difficulty of detecting the raphe this is not always easy in practice and in most cases is best done with sharp secateurs on a ripe but fairly fresh (or half-dried) fruit in which the mesocarp, endocarp and seed are still adherent to one another, using the stalk position and any hint of a ventral suture as guides for orienting the cuts.

Features of the seed coat intrusion have been described in detail in the species accounts. There is a strong correlation between the seed size and the relative volume and 
complexity of shape of the intrusion, which is doubtless explainable in terms of seed physiology (exchange of gases or solutes from endosperm?). Its dimensions have been expressed in terms of how far toward the opposite seed wall it extends (as a proportion of the dorsiventral diameter), and what proportion of the endosperm its width occupies (i.e. of the lateral diameter), and likewise what proportion of the seed length it occupies, all as approximate fractions, e.g. 3/4. But another feature of significance is the position from which the intrusion penetrates: in some species this is from a median position relative to the fruit stalk (i.e. at 9 o'clock if the fruit stalk is taken as 6 o'clock), while in others it may be from closer to the base or the apex (e.g. 10 o'clock or 7 o'clock). The embryo, which lies opposite the intrusion in a small pocket in the endosperm, varies in position in a similar way, generally between the 2 o'clock and 5 o'clock positions relative to the fruit stalk. These features of intrusion and embryo position appear to be constant for each species within quite narrow limits.

\section{Evidence of dioecy (or androdioecy)}

Uhl and Dransfield (1987) describe Livistona as 'hermaphroditic (rarely dioecious)'. Some of the Australian species display clear signs of sexual differentiation among the palms of a population, although the nature of this sexuality is still unclear. It finds its strongest expression in L. humilis, which conveniently is also the species in which it is most easily observed, flowering as it often does at only 1-2 $\mathrm{m}$ above the ground. Observation of populations of this species reveals a striking dimorphism of inflorescence structure among plants, with approximately half of them producing very elongated inflorescences with only a single, terminal partial inflorescence, lateral branching being suppressed and the rachis clothed in a long series of sterile bracts. The remaining plants have an inflorescence structure conforming to the normal Livistona pattern, with each rachis bract subtending a partial inflorescence. It was my observation that only inflorescences of the first type bear fruit, and that each plant consistently produces only one type of inflorescence, evidenced by the previous years' inflorescences either fallen on the ground or persisting on the palm. Examination of flowers found on the two inflorescence types reveals that the 'female' (fruit-bearing) plants have flowers with apparently empty anther locules, though in other respects more or less identical to flowers on 'male' plants, the stamens being of normal form. Flowers of the 'male' plants appear to have have their full complement of stamens and carpels, the latter containing apparent ovules.

The other species for which my observations clearly support sexual differentiation is L. australis, readily observable in large populations in the fringes of the Sydney metropolitan area. Although this species produces inflorescences of similar overall structure on all individuals, many palms consistently fail to bear fruit, evidenced by the fallen old inflorescences on which none of the rachillae have thickened fruit-stalk remains. In contrast, fruiting individuals consistently accumulate beneath them old inflorescences with thickened fruit-stalk remains, as well as having thicker, more decay-resistant rachillae, doubtless a consequence of the conducting and mechanical tissues that develop post-anthesis to support the masses of fruit. At flowering time, normally early to mid-August in the Sydney area, some trees can also be seen bearing ripe fruit from the previous year's flowering, but showing no sign of flowering in the current season. This observation lends partial support to that of Orscheg and Parsons (1996b), who postulate an 18-month interval between flowering and fruit fall in the southernmost stand of L. australis, and at least 2 years between successive flowerings of individual trees. They make no mention of sexual differentiation among trees. In the Sydney populations observed by me, there are slight but consistent differences between fruiting and non-fruiting trees in arrangement of flowers on rachillae, and in texture and indumentum of rachis bracts: the 'male' rachillae have closely crowded 
flower clusters that are predominantly 3-4-flowered, while 'female' rachillae have more widely spaced clusters that are predominantly 1-2-flowered; 'male' rachis bracts are papery with dense patches of tangled scales near their apices, while 'female' bracts are more leathery and with much sparser scales. Flowers of both kinds appear to have fully developed stamens and carpels. In the description of L. australis below, no attempt has been made to separate character-states of the two 'sexes', since for most flowering collections there is no record of whether or not the tree bears fruit.

Brief observations during some of my collecting trips suggest that several other species exhibit some degree of functional sexual differentiation: these include L. alfredii, L. eastonii and L. fulva. It is possible, indeed, that this is a feature of all the Australian species, or even of the genus as a whole. It remains an interesting area for further study.

\section{Relationships of the Australian Species}

Among the 16 Australian species recognised here, no clear-cut pattern of affinities is readily discernible, except that several pairs of allied species can be identified, notably L. australis-L. nitida; L. mariae-L. lanuginosa; and L. lorophylla-L. kimberleyana. As previously noted, all the Australian species except L. muelleri and L. benthamii are endemic and even these do not extend beyond the Papuan lowlands, part of the Australian plate. Present knowledge does not allow any confident statement as to affinities between the Australian and other extra-Australian species, but neither is there any strong evidence to contradict a tentative hypothesis that the Australian and the extra-Australian species belong to distinct clades, or at least that there may be several clades, of which none is shared between Australia (including the Papuan lowland) and other regions.

Only the most tentative groupings have been attempted among the Australian species, and it is quite likely that some of the features holding their component species together are the result of convergence in similar environments. Four informally designated groups are outlined below

A. 'Mariae Group' - stout-trunked palms of alluvial flood-channels and soaks in semi-arid environments, fronds large with thick ribs and thick wax layer on underside, inflorescences long, stout and rigid with numerous partial inflorescences. An apparently natural group consisting of species 1. L. mariae and 2. L. lanuginosa.

B. 'East Coast Group' - green-leaved, mesomorphic palms of rainforest margins, wet sclerophyll forest, swamp-forest and river channels. A probably heterogeneous group, having in common deep green leaves with drooping segments, and small to mediumsized, globose to subpyriform black fruit. Consists of species 3. L. benthamii, 4. L. drudei, 5. L. australis, 6. L. nitida, 7. L. decipiens, and 8. L. fulva (this last species is the most anomalous in this group, the others all having glossier leaves, glabrous beneath and with deeply bilobed segments; it may have affinities with species 9 of the following group).

C. 'Arafura Group' - small to medium-sized palms forming very extensive stands on deep sandy or lateritic interfluves in strongly monsoonal environments of far northern Australia (extending to Papuan lowlands in the case of L. muelleri). They appear to form a natural group, characterised by smallish fronds with stiff, rather shallowly bilobed segments, the petioles with an indumentum of persistent, crustose basalmasses of scales, arranged in lines; fruits are smallish, blue-black, slightly to strongly ellipsoid or pyriform. Consists of species 9. L. muelleri, 10. L. humilis, and 11. L. eastonii.

D. 'North-western Group' — small to moderately large palms of cliff-ledges, ravines and banks of non-perennial streams in semi-arid environments, the leaves deeply 
dissected with deeply bilobed segments, bluish or greyish-green with a hard, waxy cuticle, inflorescences with rather few (3-8) partial inflorescences, rachis bracts earlynecrotic and parchment-like. All are from the ranges of the Kimberley and Pilbara Regions of Western Australia except L. inermis from rocky escarpments of the Northern Territory 'Top End'. Possibly a heterogeneous group, consisting of species 12. L. inermis, 13. L. lorophylla, 14. L. kimberleyana, 15. L. victoriae, and 16. L. alfredii.,

\section{Notes on the Key}

- All leaf characters used apply only to adult leaves, defined here as leaves produced after the first flowering.

- Division of the lamina is measured on the widest segments, usually those between 4 and 8 segments away from the costa apex on either side

- Lamina length is measured from base of hastula to the longest segment apices

- Petiole width is measured just below the hastula; other petiole features such as t.s., color and indumentum are also taken to be at this point

\section{Key to the Australian species of Livistona}

1 Leaf blade very deeply divided leaving a central undivided portion not exceeding one tenth of total length (measured along broadest segments, at c. 2 o'clock position relative to apex of costa)

2 Leaves deep green or somewhat brownish green, more or less glossy at least on upper side, strikingly costapalmate with long pinnatisect central portion, costa conspicuous from above as well as from beneath

3 Small slender palm with trunk rarely over $6 \mathrm{~m}$ high or $10 \mathrm{~cm}$ diameter; leaf blade under $80 \mathrm{~cm}$ long with 50 or fewer segments, these under $15 \mathrm{~mm}$ wide below bifurcation and bifurcated to c. $7 / 8$ their free length; inflorescence with 5-6 partial inflorescences; flowers in sessile clusters; fruits obovate, under $10 \mathrm{~mm}$ long 13. L. lorophylla

$3^{*}$ Robust palm, trunk to $12 \mathrm{~m}$ or more high, $20-25 \mathrm{~cm}$ diameter; leaf blade $120 \mathrm{~cm}$ or more long with over 60 segments, these over $18 \mathrm{~mm}$ wide below bifurcation and bifurcated for about half their free length; inflorescence with 7-12 partial inflorescences; flower clusters with cluster axis to $5 \mathrm{~mm}$ long; fruits globose, mostly $12 \mathrm{~mm}$ or more in diameter 7. L. decipiens

$2^{*}$ Leaves not shiny, pale greyish green on both surfaces with hard waximpregnated cuticle, only moderately costapalmate with costa short and requiring close examination to detect it from above

4 Very slender palm, sometimes multi-stemmed, with trunk mostly under $10 \mathrm{~m}$ tall and under $10 \mathrm{~cm}$ diameter; leaf blade mostly under $70 \mathrm{~cm}$ long with segments under $15 \mathrm{~mm}$ wide below bifurcation; inflorescence under $80 \mathrm{~cm}$ long with only 2-3 partial inflorescences, the lowest subequal to the main axis

12. L. inermis

$4^{*}$ Palm to $15 \mathrm{~m}$ or more tall, trunk c. $15 \mathrm{~cm}$ diameter, always solitary; leaf blade mostly 80-100 cm long with segments 20-35 mm wide; inflorescence over $100 \mathrm{~cm}$ long with c. 8 partial inflorescences 14. L. kimberleyana

$1^{*}$ Leaf blade divided less deeply, leaving a central undivided portion always greater than one tenth of total length 
5 Leaf blade small to medium-sized, seldom exceeding $100 \mathrm{~cm}$ in length; segment lobe apices not long-attenuate and not or only slightly drooping

6 Leaf segments bifurcated to at least half of their free length, the lobes longattenuate and concurrent; blade with broad basal notch (120-200 degrees); fruits usually markedly longer than wide; trunk under $15 \mathrm{~cm}$ diameter, generally remaining clothed in old petiole stubs

7 Trunk exceeding $6 \mathrm{~m}$ with age, over $10 \mathrm{~cm}$ diameter, abruptly flared out into a bulblike base, covered in closely appressed petiole stubs in a strongly geometric pattern; leaf blade usually over $60 \mathrm{~cm}$ long, glaucous when young, with more than 40 segments; inflorescences not strongly dimorphic (on different plants), approximately equalling leaves; rachillae glabrous

11. L. eastonii

$7^{*}$ Trunk rarely attaining $6 \mathrm{~m}$, under $10 \mathrm{~cm}$ diameter, only slightly flared at base, petiole stubs persisting unevenly, not neatly geometric; leaf blade under $55 \mathrm{~cm}$ long, never glaucous, with fewer than 40 segments; inflorescences markedly dimorphic, those on fruiting plants c. twice leaf length with lateral branching suppressed and only a small terminal partial inflorescence, those on non-fruiting plants c. $1 \frac{1}{2}$ times leaf length with 4 or more partial inflorescences; rachillae bristly-pubescent with hairs c. $0.1 \mathrm{~mm}$ long 10. L. humilis

$6^{*}$ Leaf segments shallowly bifurcated, lobes mostly under $5 \mathrm{~cm}$ long; blade with very narrow basal notch (mostly under 60 degrees), appearing circular in outline; fruits globose or only slightly ellipsoid; trunk mostly over $15 \mathrm{~cm}$ diameter, generally free of old petiole stubs

8 Leaf blade c. $100 \mathrm{~cm}$ long, underside thinly glaucous and clothed in short golden-brown appressed hairs at least when young; segments bifurcated to a depth of c. $2-2.5 \mathrm{~cm}$ into rigid, converging points; inflorescences shorter than petioles, the tubular bracts of main axis rather loose, greybrown, their apices irregularly laciniate (not 2-lobed); fruits globose, over $13 \mathrm{~mm}$ diameter 8. L. fulva

8* Leaf blade c. $70 \mathrm{~cm}$ long, underside thinly glaucous, glabrous except for whitish scurfy scales on ribs; segments bifurcated to a depth of up to $5 \mathrm{~cm}$ into rigid parallel points; inflorescences equalling or slightly exceeding petioles, the tubular bracts of main axis rich chestnut-brown, their apices acutely to acuminately 2-lobed; fruits ovoid-ellipsoid, under $13 \mathrm{~mm}$ long 9. L. muelleri

$5^{*}$ Leaf blade medium-sized to large, if under $100 \mathrm{~cm}$ in length then segment lobe apices long-attenuate and at least moderately drooping

9 Leaf blade pale greyish-green to quite glaucous above

10 Leaf blade grey-glaucous on both sides with hard wax-impregnated cuticle; inflorescence rachis bracts glabrous to sparsely scaly

11 Trunk c. $30 \mathrm{~cm}$ diameter at $1 \mathrm{~m}$ above ground; partial inflorescences branched to 2 or 3 further orders, rachillae mostly over $4 \mathrm{~cm}$ long

16. L. alfredii

$11^{*}$ Trunk c. $20 \mathrm{~cm}$ diameter at $1 \mathrm{~m}$ above ground; partial inflorescences branched to 4 further orders, rachillae mostly under $3 \mathrm{~cm}$ long ...... 
10* Leaf blade grey-green to somewhat yellowish-green above, thickly pruinose below with layer of soft, delicate wax; inflorescence rachis bracts mostly clothed with dense white, woolly scales

2. L. lanuginosa

9* Leaf blade glossy mid- to deep green above

12 Leaf blade strongly pruinose beneath with layer of soft, delicate wax; inflorescence axis straight and ascending, bearing 10 or more partial inflorescences 1. L. mariae

$12 *$ Leaf blade not pruinose or glaucous beneath, more or less concolorous though usually less glossy beneath

13 Widest primary leaf segments mostly less than $30 \mathrm{~mm}$ wide below point of bifurcation; fruit slightly pyriform, under $12 \mathrm{~mm}$ diameter

14 Trunk (of mature palm) smooth toward base without persistent petiole stubs; leaf blade mostly over $100 \mathrm{~cm}$ long, drying dull greyish-brown above, paler brown beneath; inflorescence rachis bracts coarsely striate with regularly cuspidate apices

4. L. drudei

$14^{*}$ Trunk with persistent, widely diverging petiole stubs toward base (unless exposed to fires); leaf blade seldom more than 100 $\mathrm{cm}$ long, drying to somewhat glossy pinkish-brown above contrasting with olive brown beneath; inflorescence rachis bracts finely and obscurely striate with narrowly triangular apices

3. L. benthamii

$13^{*}$ Widest primary leaf segments mostly more than $30 \mathrm{~mm}$ wide below point of bifurcation; fruit quite spherical, over $12 \mathrm{~mm}$ diameter

15 Leaf blades mostly under $140 \mathrm{~cm}$ long, the segments bifurcated for little more than half their free length; fruits dull blackish often with brownish or reddish tones; mesocarp sparsely fibrous, inner face of endocarp not reticulate 5. L. australis

$15^{*}$ Leaf blades mostly over $140 \mathrm{~cm}$ long, the segments bifurcated for about two-thirds their free length; fruits glossy black; inner layer of mesocarp densely fibrous, inner face of endocarp reticulately patterned

6. L. nitida

\section{Treatment of species}

1. L. mariae F. Muell.

Mueller (1874: [221], 283; 1875: 222; 1878: 55; 1892: 112); Drude (1893: 39); Dammer (1905: 297); Beccari (1921: 19; 1931: 92); Lothian (1958: 92); Moore (1963: 150); Latz (1975: 189).

Type citation: 'in valle "Glen of Palms" montium Gillii; Ernestus Giles'.

Type: Corresponding to this citation are two sheets in MEL - the first is a whole leaf, roughly folded, labelled 'Gills Range, Giles'; the second consists of a few segments only, labelled 'Gills (Macdonnells) Range, E. Giles'. The former of these I here designate as lectotype of L. mariae. [Mueller's mixed concept of 1878 is discussed under Note 1, below, and also under L. alfredii ]

Saribus mariae (F. Muell.) O. Kuntze, Rev. Gen. Pl. 2: 736 (1891). 
Trunk solitary, straight or frequently curved or kinked, to c. $28 \mathrm{~m} \mathrm{high,} \mathrm{c.} 40 \mathrm{~cm}$ diameter at $1.5 \mathrm{~m}$ above ground, tapering gradually but perceptibly upward to a final constant diameter of c. $30 \mathrm{~cm}$, broadening below into a gently bulbous base c. $50 \mathrm{~cm}$ diameter sitting on a pedestal of densely massed roots sometimes $50 \mathrm{~cm}$ or more high. Surface moderately smooth but with stepped sheath scars, more strongly stepped petiole scars; vertical fissures numerous, some short and closed, others long, deep and gaping; petiole-stubs present mainly at extreme base, short, semi-appressed.

Crown moderately open, globose to somewhat umbrella-shaped, consisting of c. 35-50 spreading to drooping massive leaves, their blades extending in same plane as petioles but with pendulous or at least nodding segment-lobes. Ligules prominent, pale straw-coloured aging to dirty white, bearing dense shaggy whitish scales.

Petiole 150-260 cm long, 20-45 mm wide, triangular in t.s. with rounded keel, slightly concave above sometimes with 1 or 2 slight raised ridges. Margins minutely and irregularly denticulate in apical $1 / 3$ to $2 / 3$, with frequent small dark brown calli, some projecting, others slightly depressed; toward base armed with blackish, blunt, patent prickles to c. $3 \mathrm{~mm}$ long. Surfaces yellowish-green, the upper with very crowded, deep, subparallel, linear pits, up to $10 \mathrm{~mm}$ long, most abundant on median band of petiole, on younger leaves obscured by dense shaggy white scales, these semi-appressed, mostly with elongated bases, laciniately dissected, the laciniae narrowly straplike, c. $5 \mathrm{~mm}$ long, mostly straight but helically twisted and apically tufted; older petioles with smaller scale-remnants persisting; lower surface similar but pits shallower, sparser; more sparsely scaly, scales densest close to margins, laciniae mostly under $3 \mathrm{~mm}$. Hastula flattish; base shallowly 3-lobed, the central lobe longest; rim at c. $30^{\circ}$ to costa, to c. $15 \mathrm{~mm}$ wide, \pm triangular, acute, with disintegrating necrotic margin.

Lamina 130-220 cm long, c. $0.3 \mathrm{~mm}$ thick, moderately to strongly costapalmate with broad basal sinus, fairly rigid but somewhat brittle, easily split; slightly to moderately contorted with 1 gentle adaxial undulation either side of the slightly deflexed costa and base on either side slightly involute. Segments 37-43 either side of costa; largest segments $38-45 \mathrm{~mm}$ wide, free for $45-55 \%$ of their length, bifurcated for $45-65 \%$ of free length, the lobes parallel to slightly diverging, tapering into fine but not aristate or threadlike apices, slightly bristly, early-necrotic, mostly broken-off and split. Intersegmental appendages present, to c. $30 \mathrm{~cm}$ long, moderately thick and tough, bearing short woolly scales Ribs: abaxial ribs large and prominent, in t.s. oblong to trapeziform (narrowing to lamina), sharply square-edged or slightly rounded on one side, $0.8-1.2 \mathrm{~mm}$ thick, $1.8-2.5 \mathrm{~mm}$ deep; adaxial ribs more narrowly oblong, c. $0.7 \mathrm{~mm}$ thick, 1.5-2.5 mm deep. Venation: major longitudinal veins 7-9 either side of abaxial rib, moderately prominent on both surfaces; transverse veins evident but not prominent above, moderately prominent beneath, rather widely spaced, mostly near-orthogonal with respect to longitudinal veins, mostly discontinuous, generally sigmoid or more finely sinuous. Surfaces: upper pale to deep glossy green, variably glaucous with delicate waxy bloom, glabrous; lower dull pale green with coating of thick, soft wax, glabrous except for whitish scales on bases of ribs.

Inflorescences mostly shorter than petioles, though sometimes approaching $2.5 \mathrm{~m}$ in length, very stiff and straight. Partial inflorescences c. 10-14, subequal, short relative to rachis, stiff and forward-pointing to moderately recurved, each branched to 4 further orders; rachillae 3-8 cm long, c. 0.8-1.0 mm thick, glabrous, irregularly striate, minutely white-papillose. Rachis bracts cylindrical or slightly flattened, larger ones 4-5 cm diameter, tightly sheathing, smooth or with few coarse transverse wrinkles, rigidly coriaceous, remaining entire and generally untorn through to fruit, pale green aging yellowish, sparsely to densely covered in shaggy white loosely appressed scales, these deeply laciniate with straight, helically twisted laciniae to c. $6 \mathrm{~mm}$ long, or subentire and strongly undulate, tufted at apices; bract-apices ovate-acuminate, sometimes drawn out into a long slender point. Flower-clusters $0.5-2 \mathrm{~mm}$ apart, 
3-6-flowered; cluster axis to $1.3 \mathrm{~mm}$ long, fleshy, arcuately deflexed with flowers tightly crowded secundly on adaxial (outer) side. Cluster-bract short and broad, c. $0.3 \mathrm{~mm}$ long, lacerately toothed or entire and broadly acute, membranous, hidden beneath cluster axis. Bracteoles 1(?) per flower, very short, crowded.

Flowers 1.5-1.8 mm long, globose-campanulate. Anthopodium c. $0.15 \mathrm{~mm}$ long, minutely recessed at base with sharp narrow rim, minutely trigonous. Sepals closely appressed to petals, strongly concave, membranous, $0.8-1.0 \mathrm{~mm}$ long, connate for c. $1 / 2$ their length with rather narrow, angular sinuses, free portion ovate, broadly acute to somewhat rounded, sometimes awned with one or more delicate hairlike laciniae c. $0.3 \mathrm{~mm}$ long. Petals fleshy, strongly concave, $1.2-1.5 \mathrm{~mm}$ long, connate for c. $1 / 10$ their length, suborbicular to broadly oblong, broadly acute with strongly thickened apex, auriculate at base, the auricles minute, retrorse, narrow; inner face with 3 deep cavities. Stamens c. $3 / 4$ as long as petals, connate for c. $3 / 8$ their length; filaments very small, rather membranous, triangular-acuminate, distinctly shouldered a little above base, thence tapering very smoothly into a slender apex; anthers c. $0.4 \mathrm{~mm}$ long, about the same wide. Carpels from $2 / 3$ as long as to subequal to stamens; ovaries globose-obovoid, strongly gibbous abaxially, gradually to abruptly contracting into styles $0.2-0.3 \mathrm{~mm}$ long.

Fruit \pm spherical to slightly flattened, $13-17 \mathrm{~mm}$ diameter; suture sometimes evident; base quite rounded or with very slight conical protrusion. Epicarp glossy black or with patches of mahogany-brown, with fairly conspicuous scattered pale brown spots 0.2-0.5 mm diameter, some with slits or pores. Mesocarp 2-2.5 mm thick when fresh (c. $1.5 \mathrm{~mm}$ dry), purplish green, thick and fleshy, fairly soft; granular in texture when dry ; containing thick, fairly crowded, moderately straight fibres largely confined to inner half of mesocarp and very prominent on its inner face in old fallen fruits. Endocarp 0.2-0.25 mm thick, straw-coloured, brittle, adhering fairly closely to mesocarp; inner surface smooth with conspicuous regular pattern of very close, pale orange-brown dots, outer surface sometimes deeper orange-brown, obscurely verruculose with a similar patterned appearance. Seed markedly flattened ventrally, c. 7.5-12 mm long and wide; surface pale grey-brown, dull and minutely rough with very fine pattern of spots and radiating whitish cells except for shiny deeper brown hilum. Intrusion short and broad, penetrating transversely from slightly above median position for $3 / 5$ seed diameter, in l.s. with broadly flared base, usually constricted at middle, shallowly to deeply 2-lobed or unlobed, usually lumpy in outline, occupying $1 / 2$ or slightly more of seed length; in t.s. less flared at base, more markedly 2-lobed, occupying less than $1 / 2$ of seed width. Embryo sub-basal (c. 5 o'clock relative to stalk).

Distribution: see under subspecies below.

Ecology: essentially a palm of stream-channels, associated with permanently flowing water or permanent pools or soaks; also in rocky beds of sandstone gorges or occasionally on lower ledges of cliffs, but in these situations always on permanent soaks. It is associated with a variety of vegetation types, e.g. fringing forest/woodland of Eucalyptus camaldulensis in Central Australia, gallery-forest of Melaleuca leucadendra, Nauclea orientalis, Ficus racemosa, Pandanus aquaticus in northwest Queensland and the Northern Territory. In the Durack Range it was observed in close association with Livistona kimberleyana while at Kapalga in Arnhem Land it was reported to occur with L. benthamii.

\section{Notes}

1. Mueller first referred to this species without name in 1874 in a brief paragraph appended to his description of Livistona leichhardtii. He postulated that Giles's collection from the 'Glen of Palms' (consisting of a single leaf without petiole) might possibly be conspecific with his L. leichhardtii (now regarded as an illegitimate name); 
he refers to its characters in the most sketchy way, viz., 'sub hastis clavisque barbarorum segmenta usque $4^{\prime}$ longa exhibet'.

2. Mueller's next mention of this palm was in the 'Additamenta' of the same volume of the Fragmenta, also issued in 1874, in the form of a brief statement: 'Palma Gilesii huic non conspecifica, sed fortasse congenerica, et tunc L. Mariae dicanda'. Chapman (1991) treats this as the place of publication of the name Livistona mariae, commenting 'Combination made by reference to $8: 221 \ldots$ '. Chapman's acceptance of this as place of publication is endorsed here, even though Mueller's diagnosis rather doubtfully meets the requirements of the present Code.

3. By the time Mueller came to publish a full botanical account in the Fragmenta, another occurrence of a Livistona had been discovered by Forrest, also distantly isolated from any other palms, and Mueller concluded (wrongly, as he later admitted) that it represented the same species.

4. The more ample 1878 description of L. mariae in Mueller's Fragmenta was based on Giles's leaf specimen and flowers and fruits collected by Forrest in northwestern Australia. Mueller acknowledged these were unconnected but nonetheless concluded 'sed plantam ex utraque regione conspecificam arbitror'. As early as 1879 he was sent fruits from the Palm Valley Livistona by the missionary Kempe, and his growing doubts culminated in his publication of the 1892 note in the Victorian Naturalist, generally regarded as the protologue of L. alfredii (see also notes under that species). If Mueller's 1874 mention of L. mariae is not regarded as valid publication of the name, then this 1878 description would have to be regarded as the protologue. But that would leave unresolved the problem of typification of the name L. mariae, due to the mixture of elements on which this later description is based, which is a pragmatic argument for allowing the 1874 publication of the name.

5. Chapman's (1991) note under L. mariae, 'Also published by Mueller in Gard. Chron. (June 1879) 790,' is misleading, in that this article has no descriptive material except for: 'Von Müller hopes shortly to succeed in introducing Livistona Mariae into Europe, where its peculiar pale green colour will contrast well with its more highly coloured eastern congeners.' Moreover he appears to have overlooked Mueller's 1878 description (see previous paragraph).

6. Subsequent authors such as Drude (1893) and Beccari (1921, 1931), following Mueller's 1892 note, interpreted L. mariae in the present sense, firmly establishing its application to the Central Australian palm. C.A. Gardner (1923), however, seemed totally confused, applying L. mariae to the Fortescue River palm and L. alfredii to a Kimberley palm (see notes under L. alfredii and L. kimberleyana).

7. Beccari $(1921,1931)$ failed to perceive any resemblance between his L. rigida and L. mariae, perhaps understandably in view of the fragmentary material he had available of both. It seems strange nonetheless for him to have speculated that his new species might prove identical with Brown's L. inermis, a species far smaller in leaf dimensions, which in fact he described quite accurately; perhaps he was too influenced by their geographic proximity.

8. The decision here (see below) to treat the Central Australian palms as conspecific with the various northern Australian populations is perhaps somewhat controversial. However, although there are slight but apparently consistent differences in leaves, rachis bracts and fruits, the resemblances in detail in most organs are so striking as to suggest overwhelmingly that this is all the one species. Unfortunately this conclusion is at present based on very inadequate collections, and a clear picture of variation must await comprehensive sampling of adult leaves, flowers and mature fruits from all populations. In particular the Western Australian plants are very poorly known. 
But, as with any disjunct occurrences of slightly differing plants whose relationship is clearly one of vicariance, the decision to separate or combine them at species level must in the end be arbitrary.

9. The most useful solution at this stage would seem to be to treat the entities that can be detected within L. mariae s. lat. as subspecies. The following subspecific classification is therefore proposed.

\section{Key to Subspecies}

1 Adult leaf blade mostly exceeding $2 \mathrm{~m}$, segments drooping, bifurcated for about $2 / 3$ of their length; upper surface glossy green; fruit c. $15 \mathrm{~mm}$ diameter subsp. mariae

$1^{*}$ Adult leaf blade mostly under $1.8 \mathrm{~m}$, segments stiff or slightly drooping, bifurcated for about $1 / 2$ of their length; upper surface thinly glaucous, fruit c. $13 \mathrm{~mm}$ or less diameter

2 Rachis bracts with moderately dense scales especially toward apices

subsp. rigida

2* Rachis bracts virtually glabrous except for a few sparsely scattered white scales near apex subsp. occidentalis

subsp. mariae

The type subspecies is characterised in the field by its greener, more glossy upper leaf surfaces and longer, more drooping leaf segments. Table 3 details the comparative leaf dimensions and ratios of this and the other two subspecies. The rachis bracts are rather densely clothed with persistent white scales, though usually with some relatively bare areas especially on the lower part of the bract. Ripe fruits are $13-16 \mathrm{~mm}$ in diameter, virtually spherical and glossy black; seeds are 10.5-12.0 $\mathrm{mm}$ long (the smallest diameter may be under $10 \mathrm{~mm}$ ). (Fig. 3a, 5a)

Distribution: Central Australia: Restricted to Palm Valley, on the Finke River where it cuts through the Macdonnell Range, west of Alice Springs. A relict occurrence of only about 1500 adult palms, about $12 \mathrm{~km}$ separating its furthest limits (Latz 1975).

Conservation status: 2VCa (Briggs \& Leigh 1996)

Specimens examined: Northern Territory: Central South: Gills (Macdonnells) Range, Giles s.n. (MEL); Palm Valley, Mitchell 84, 25 Sep 1974 (DNA); Palm Valley, beside Palm Creek near ruins of Chalet, Rodd 3215 E Jacobs, 29 May 1976 (NSW, DNA); Palm Valley, Lothian 315, 1954 (AD). Palm Valley, Cleland s.n., 17 Aug 1929 (AD).

subsp. rigida (Becc.) A.N. Rodd, comb. nov.

Livistona rigida Becc., Webbia 5(1): 19 (1921).

Type citation: 'Albert River nel Golfo di Carpentaria (Erb. di Kew). Collettore ignoto.'

Type: Albert River, Ferd. Mueller; holo K. [Mueller may have distributed the specimen from MEL and is not necessarily the collector.]

Differs from subspecies mariae in its slightly shorter leaves with shorter bifurcation of segments, more glaucous upper leaf surface, less dense indumentum of shaggy white scales on rachis bracts, and slightly smaller fruit and seed. Schneider s.n. has fallen mature fruit $14 \mathrm{~mm}$ long, 12-13 mm wide. Seed $10 \mathrm{~mm}$ diam; inner mesocarp with conspicuous dense straight fibres. For differences from subsp. occidentalis see under that subspecies. (Fig. 3b, 5b-c, 6) 
Table 3. Comparison of selected characters of subspecies of $L$. mariae.

Note: Leaf dimensions are based largely on my own collections Rodd 2868, 2937 and 3215, as none of the other available collections have undoubtedly adult leaves.

\begin{tabular}{|c|c|c|c|}
\hline subspecies & mariae & rigida & occidentalis \\
\hline $\begin{array}{l}\text { lamina } \\
\text { length }\end{array}$ & c. $220 \mathrm{~cm}$ & c. $160 \mathrm{~cm}$ & c. $175 \mathrm{~cm}$ \\
\hline $\begin{array}{l}\text { depth of } \\
\text { primary } \\
\text { division }\end{array}$ & $\begin{array}{l}\text { c. } 120 \mathrm{~cm} \\
(55 \%)\end{array}$ & $\begin{array}{l}\text { c. } 80 \mathrm{~cm} \\
(50 \%)\end{array}$ & $\begin{array}{l}\text { c. } 40 \mathrm{~cm} \\
(48 \%)\end{array}$ \\
\hline $\begin{array}{l}\text { depth of } \\
\text { bifurcation }\end{array}$ & $\begin{array}{l}\text { c. } 75 \mathrm{~cm} \\
(63 \%)\end{array}$ & $\begin{array}{l}\text { c. } 40 \mathrm{~cm} \\
(50 \%)\end{array}$ & $\begin{array}{l}\text { c. } 40 \mathrm{~cm} \\
(48 \%)\end{array}$ \\
\hline $\begin{array}{l}\text { upper } \\
\text { surface }\end{array}$ & glossy & glaucous & glaucous \\
\hline $\begin{array}{l}\text { main } \\
\text { inflorescence } \\
\text { bracts }\end{array}$ & $\begin{array}{l}\text { densely } \\
\text { scaly }\end{array}$ & $\begin{array}{l}\text { less densely } \\
\text { scaly }\end{array}$ & $\begin{array}{l}\text { almost } \\
\text { glabrous }\end{array}$ \\
\hline $\begin{array}{l}\text { fruit } \\
\text { length }\end{array}$ & $13-16 \mathrm{~mm}$ & $14 \mathrm{~mm}$ & unknown \\
\hline $\begin{array}{l}\text { seed } \\
\text { length }\end{array}$ & $10.5-12.0 \mathrm{~mm}$ & $10 \mathrm{~mm}$ & unknown \\
\hline
\end{tabular}

Distribution: this subspecies is known from several disjunct areas: 1 . far northwest Queensland, along sections of the Albert, Nicholson, Gregory and Leichhardt Rivers and Lawn Hill Creek, also reportedly on coastal sands opposite Mornington Island this is the most extensive occurrence, extending southeast almost to Mount Isa; 2. upper Roper River, Northern Territory, in a small area close to Mataranka; 3. Kapalga, near the East Alligator River, Arnhem Land; and 4. Upper Goyder River in northeastern Arnhem Land - the last two, each known from a single collection, are about 2 degrees of latitude north of Mataranka; the intervening region may not have been adequately investigated for palms.

Conservation status: none assigned by Briggs and Leigh (1996); 3RCa is suggested.

Specimens examined: Queensland: Burke: Babbling Brook, Lawn Hill Stn, Latz 1619, 24 July 1971 (DNA, CANB); Lawn Hill Creek, Rodd 2937, 2938, Dec 1974 (NSW, BRI, K); Lawn Hill Creek, SW of Burketown, Gittins, June 1963 (BRI); Lake Julius Dam below dam wall, [collector?], 12 Feb 1977 (BRI).

Northern Territory: Darwin and Gulf: Kapalga, Dunlop 5052 \& McKean, 14 Feb 1979, (DNA, CANB, NSW); Goyder River, Dunlop 7259, 2 Nov 1987 (DNA, NSW); Roper Highway, 20 k E Stuart Highway, Latz 7828, 19 June 1978 (DNA, NSW); Warlock Ponds Bridge, S of Mataranka, Symon 10358, 8 May 1975 (NSW); Mataranka, Maloney s.n., 13 July 1975 (NSW); Mataranka Station, Salt Creek, Schneider s.n., 5 July 1964 (AD).

subsp. occidentalis Rodd, subsp. nov.

Differt a subsp. mariae et subsp. rigida bracteis majoribus inflorescentiae fere glabris.

Type: Western Australia: SE base of Mt King, Durack Range, Rodd 2868, Dec 1974; holo NSW; iso PERTH, K, BH. 
The only character so far known in which this differs from both the other subspecies is its almost glabrous rachis bracts. In leaf characters it matches subsp. rigida quite closely, notably in its overall blade length, depth of dissection, length of secondary lobes, and moderately glaucous upper surface of lamina, in all of which these two subspecies differ from subsp. mariae. Comparisons of flowers and mature fruits are not yet possible, due to lack of material. Recognition of this population as a separate subspecies on the basis of a single wild collection (and one from cultivation) is arguably rather premature, but represents a middle course between simply submerging it in subsp. rigida and treating it as a distinct species. (Fig. 3c, 5d)

Distribution: as so far known, this subspecies occurs in the gorges of the Durack and King Leopold Ranges, central Kimberley region, Western Australia. In the Durack Range it has been collected at Mt King and near El Questro Homestead, and seen from air in gorges between these points. In the King Leopold Ranges it has been collected at Mt Gladys, and apparently similar palms are reported by Dr Peter Wilson (NSW) in Brownrigg Gorge near the very head of the Lennard River in the King Leopold Range.

Conservation status: none assigned by Briggs and Leigh (1996); a coding of 3VCi is suggested.

Specimens examined: Western Australia: Bens Springs, $3 \mathrm{~km}$ E of El Questro Homestead, Kenneally 10965, 29 June 1989 (PERTH).

Cultivated: Queensland: Townsville Palmetum, Dowe 117, 9 Dec 1993 [ex seed from Broome Botanical Society: Mt Gladys, Leopold Range, T. Willing s.n., May 1987] (NSW).

\section{L. lanuginosa A.N. Rodd, sp. nov.}

Palma magna affinis L. mariae habitu similique: folia valde undulata costa elongata valde deflexa; lamina profunde dissecta, griseo-viridia, infra velamine crasso cerae, petiolo supra squamas densas albo-lanuginosas ferenti. Inflorescentiae foliis breviores, axe principali recto crassoque, bracteis vaginatis squamas albo-lanuginosas dense ferentibus. Fructus magni, usque ad $3.5 \mathrm{~cm}$ diametro, atrocastanei ubi maturi, punctis minutis suberosis sparsis ferentes, mesocarpio crasso.

Type: Queensland: Glenroy Creek, 75 km SE of Ravenswood, 20³5'S, 147¹'E, A.K. Irvine 1912, 25 Aug 1978; holo NSW; iso QRS, BRI, BH, MEL.

[Livistona sp. 'Cape River' (Jones 1984, Dowe 1990)]

Trunk solitary, straight, to c. 15 (20?) $\mathrm{m}$ tall, c. $35 \mathrm{~cm}$ diameter at $1.5 \mathrm{~m}$ above ground, broadening gradually downward and flaring widely at very base to $50-60 \mathrm{~cm}$ diameter above a slight pedestal of exposed roots. Surface rather corky on lower trunk, usually with persistent appressed petiole stubs to $20 \mathrm{~cm}$ long on basal 1-2 m, as well as some step-like petiole scars; upper trunk surface very rough, with distinct annular sheath-scars; vertical fissures numerous, shallow on lower trunk, deep and zig-zagging on upper (some very long).

Crown \pm globose or somewhat umbrella-shaped, rather open, consisting of c. 35-45 strongly ascending to horizontally spreading or slightly drooping greyish leaves with stiff petioles and downward-curving leaf-blades with arching to pendulous segment lobes. Ligules moderately prominent, pale straw-coloured ageing to dirty white, with inconspicuous but fairly dense whitish scales.

Petiole 150-200 cm long, 30-35 mm wide; triangular-flattened in t.s. with rounded keel, concave above near lamina but with slight median keel in mid-region. Margins mostly unarmed for upper $2 / 3$ or more, toward base armed with mostly patent (some antrorse or retrorse), broad-based blackish prickles to $3 \mathrm{~mm}$ long; surfaces yellowish-green right to base, upper obscurely striate, hardly pitted, at first densely whitish-woolly over most of length, with deeply laciniate, antrorsely appressed scales 
to $5 \mathrm{~mm}$ long, the laciniae straight or sharply bent, spirally twisted, becoming tangled with age, deciduous on older petioles leaving numerous minute, oval to elliptic, pustular, hardly raised pale grey-brown basal-masses; lower surface almost glabrous, hardly striate, with dark brown streaky markings and irregular, shallow, elongated pits, few inconspicuous appressed white scales sometimes present in long narrow rows either side of keel. Hastula base V-shaped, slightly cuspidate; rim at $40-50^{\circ}$ to costa, to c. $12 \mathrm{~mm}$ wide, fairly straight and even, with narrow to broad necrotic margin. Lamina 130-190 cm long, $0.3 \mathrm{~mm}$ thick, strongly costapalmate, \pm truncate at base, rigidly coriaceous, not readily splitting, strongly contorted with 3 adaxial undulations either side of a deep median crease along the strongly decurved costa, sharply involute either side at base with 3-4 lowermost segments resupinate. Segments 42-46 either side of costa; largest segments $36-42 \mathrm{~mm}$ wide, \pm parallel-sided, free for $60-70 \%$ of their length, bifurcated for $50-75 \%$ of free length, the lobes moderately diverging and arching with pendulous tips, evenly tapering but drawn out into fine, flexible apices which on older leaves are shortly necrotic but remain entire. Intersegmental appendages \pm persistent, threadlike but moderately tough, to $20 \mathrm{~cm}$ long, dark greyish, densely white-woolly at first, glabrescent. Ribs: abaxial ribs in t.s. oblong, narrowing slightly to lamina, square-edged, $0.9-1.3 \mathrm{~mm}$ thick, up to $3.0 \mathrm{~mm}$ deep; adaxial ribs similar, $0.8-1.2 \mathrm{~mm}$ thick, $2.0-3.0 \mathrm{~mm}$ deep. Venation: major longitudinal veins 7-9 either side of abaxial rib, moderately conspicuous above, evident but not prominent beneath; transverse veins barely discernible above, moderately prominent beneath, mostly near-orthogonal with respect to longitudinal veins, mostly arcuate or sinuous, mostly discontinuous. Surfaces both somewhat yellowish pale green but appearing pale bluish-grey, strongly pruinose, especially the lower which has a persistent thick coating of white wax readily rubbing off onto fingers; glabrous except for ribs on both sides toward base clothed in dense, moderately persistent, whitish matted scales as on adaxial petiole surface.

Inflorescences slightly longer than petioles, \pm erect but with strongly deflexed branches, rachis stout and fairly straight. Partial inflorescences 9-12, subequal, the largest approaching $1 / 2$ of rachis in length, branched to 4 further orders; rachillae 3-12 cm long, c. $0.8 \mathrm{~mm}$ thick, creamy-white, finely wrinkled-striate, glabrous; larger axes toward base of each partial inflorescence densely white-woolly, soon glabrescent post-anthesis, with sinuous, dendritically-branched hair-like scales c. $3 \mathrm{~mm}$ long, leaving minute, numerous granular-papillose remnants after shedding. Rachis bracts somewhat flattened, the largest $3.5-4 \mathrm{~cm}$ diameter, rigidly coriaceous, tightly sheathing, smooth or \pm buckled with transverse wrinkles, pale green with short red-brown necrotic apical zone, conspicuously striate with prominent raised veins, densely and persistently lanuginose, most densely toward apices, with matted tomentum c. $2 \mathrm{~mm}$ thick, straw-coloured ageing greyish-white, consisting of scales c. $5 \mathrm{~mm}$ long, divided right to base into dense tufts of plumose, hair-like, straight or slightly sinuous laciniae which become curled and matted with age, the shed scales leaving inconspicuous but dense, hardly raised, elongated basal-masses concolorous with bract surface; bract-apices triangular-ovate, somewhat abruptly cuspidate or acuminate with fine, soft points which soon shrivel and break off. Flower-clusters $1-3 \mathrm{~mm}$ apart, 1-flowered; cluster axis vestigial, $0.2-0.3 \mathrm{~mm}$ long, conical, projecting from a larger chin-like protuberance from rachilla. Cluster-bract broad-based with narrow-triangular, acute central portion, marcescent post-anthesis. Bracteole 1, immediately above and laterally overlapping cluster-bract.

Flowers c. $3.0 \mathrm{~mm}$ long, funnel-shaped. Anthopodium $0.5 \mathrm{~mm}$ or less long, c. $0.9 \mathrm{~mm}$ wide, tapering, deeply recessed at base with a sharp rim and 3 obscure downward bulges, completely concealing cluster axis. Sepals closely appressed to petals, very concave basally, thick and pigmented except for narrow, thin, translucent margin, c. $1.5 \mathrm{~mm}$ long, connate for almost half their length with broad, shallow sinuses, narrowly triangular, sharply acute to finely acuminate or even aristate at apex. 
Petals very thick, tough, moderately concave, 2.8-3.0 mm long, connate for c. $1 / 4$ their length, rather narrowly ovate-triangular; mostly sharply acute at the strongly thickened, barely inflexed apex auriculate at base, the auricles quite large, sometimes broadly overlapping; inner faces with 3 long, deep cavities. Stamens $3 / 5$ to $2 / 3$ as long as petals, filaments broadly oblong with rounded apex to almost semicircular in outline, not or barely shouldered, narrowed very abruptly into short, very slender apex; anthers c. $0.4 \mathrm{~mm}$ long. Carpels slightly shorter than stamens; ovaries obovate to obconical, strongly gibbous abaxially, narrowed very abruptly into slender, frequently curved styles c. $0.5 \mathrm{~mm}$ long.

Fruit \pm spherical, shallowly conical at base, 33-36 mm diameter. Epicarp moderately tough, dark purplish-brown when ripe, smooth and moderately shiny, slightly pruinose, with sparsely but evenly scattered pale brown pustules $0.3-1.0 \mathrm{~mm}$ diameter, each with small circular pore or 3-cornered slit in summit. Mesocarp to c. 4 mm thick, granular-fleshy, moderately juicy when fresh, containing numerous thick fibres much denser toward inner face, tending to be parallel in basal half and anastomosing in apical half, prominent on inner wall at least in fallen fruits. Endocarp 0.3-0.5 mm thick, quite hard, tough and springy, pale straw-coloured, minutely rugulose on both faces but appearing smooth and matt-surfaced except for prickle-like projection at stalk position. Seed subspherical, very slightly flattened on ventral face, c. $22 \mathrm{~mm}$ long, $21 \mathrm{~mm}$ wide, 19-20 mm thick, with distinct, large raphal scar at base; surface smooth, mottled pale and dark red-brown; seed-coat mostly c. $1.0 \mathrm{~mm}$ thick. Intrusion very large, occupying most of seed volume, penetrating $4 / 5$ or more of seed width from a lateral position, in l.s. very broad-based but broadening into irregular, vaguely circular outline, divided somewhat into 2 lobes, occupying $2 / 3$ of seed length; in t.s. similar in outline but slightly narrower, occupying slightly over $1 / 2$ seed width. Embryo large, sub-basal (4.30-5.00 o'clock relative to stalk). (Fig. 3d, 7, 9a)

Distribution: restricted to a small area of the Burdekin River basin, tropical east Queensland, 100-200 km from the coast, between latitudes $20^{\circ} 30^{\prime}$ and $21^{\circ}$, and altitudes $150-300 \mathrm{~m}$.

Ecology: known only along sandy river and creek channels that flow only for part of the year but with permanent pools or soaks; associated trees are Eucalyptus camaldulensis, Melaleuca leucadendra, and Pandanus ?cookii.

Conservation status: 2V (Briggs \& Leigh 1996).

Specimens examined: Queensland: North Kennedy: Glenroy Creek $75 \mathrm{~km}$ SE of Ravenswood, Irvine 1913, 25 Aug 1978 (QRS, NSW); Glenroy Creek, c. 11 km N of Burdekin Falls, Rodd 3759 E Jackes, 25 Nov 1981 (NSW); Glenroy Creek c. 3km from Glenroy Station homestead, McLain 2, Feb 1978 (QRS); Middle Burdekin Valley somewhere near Burdekin Falls, McLain s.n., 1978 (or possibly 1977) (NSW).

Cultivated: Queensland: Townsville Palmetum, Dowe 111, 18 June 1993 [ex seedlings: upper reaches of Burdekin River in vicinity of Burdekin Dam wall, R. Tucker s.n., 1986] (NSW).

\section{Notes}

1. Bailey (1902) included 'L. mariae' in his Flora, with description probably drawn largely from those of Mueller and Bentham. Instead of citing a region or locality for its occurrence, however, he only notes: 'I have received a portion of a leaf from F.L. Berney of Hellenslie, Campaspe River, which in all probability belongs to this inland palm.'

2. The above record aroused my interest in the early stages of this project, in that there had not been any other report of palms from this region of Queensland except those much closer to the coast (L. decipiens, L. drudei, L. australis). In 1976 a visit was made to 'Helenslee' (as it is now spelt on the map), which is near the head of the Campaspe about $30 \mathrm{~km}$ east of Pentland. The manager of the property knew of no palms in the vicinity at all, and the river bed there appeared an unlikely habitat for palms. 
It was concluded that the specimen sent to Bailey (which has apparently not been preserved) must have been collected from some more distant locality.

3. Quite coincidentally, in 1977, word reached palm collectors in Sydney that an apparently quite new Livistona had been discovered in the middle-lower area of the Burdekin, by Peter McLain, an enthusiastic young horticulturist and plant collector from Ayr near Townsville. Seeds of the palm distributed by him were seen to be much larger than those of any Australian Livistona except L. alfredii.

4. Tony Irvine, CSIRO botanist from Atherton with a specialist interest in palms, followed up Peter McLain's discovery with an investigation of his own, making collections and field observations which he very generously communicated promptly to me. He revisited the stand known to McLain on Glenroy Creek, south of Ravenswood not far from Burdekin Falls.

5. Tony Irvine also, following a chance remark made to him, called on Mr Jim Rollinson of 'Nosnillor', a large property situated at the junction of the Cape and Campaspe Rivers. Around the homestead he found a number of mature plants of this same species, and was informed that these had been transplanted as seedlings by $\mathrm{Mr}$ Rollinson from a distant part of his property on the Cape River over thirty years previously. In September 1978 I visited 'Nosnillor' and photographed these same plants, but was told that the area of river where they occur wild was not accessible by vehicle. Tony Irvine was also informed by $\mathrm{Mr}$ Rollinson that there is another occurrence of these palms on the property 'Harvest Home', lower down the Cape River.

6. The species clearly occupies only a very limited area of the Burdekin Basin. At least some of the known stands exhibit vigorous regeneration with most age-classes represented, but it is possible that, in a climate marginal for palm survival, there are periodic droughts resulting in death of all stands other than those on the most permanent soaks in stream beds; otherwise it is difficult to understand why an apparently so vigorous and hardy species should not be more widespread, as its seeds are well adapted to dispersal by floods. This reasoning applies equally to the similarly restricted L. mariae and L. alfredii.

7. Dowe (1990) says of Livistona sp. 'Cape River': 'Distribution of this species is relatively widespread, being found as far north as the tributaries [of the Burdekin] which have their source west of Ingham; near to Greenvale in the west; to the Cape River in the south and to Ravenswood in the south-east. The distance from north to south is about $200 \mathrm{~km}$, but this may be misleading as groups are usually very small (this species does not form colonies as do other Livistona spp.) and are widely located.' Dowe does not state whether this account is based on his own observation. He concludes that its endangered status falls into the category of 'Restricted distribution and uncommon: presently threatened', one of only two Australian palms placed by him in this category.

8. L. lanuginosa is a very distinct species, instantly recognisable by the abundant woolly scales on petioles and rachis bracts and by the very large, brownish fruits. Its closest affinity is clearly with L. mariae, there being in particular a striking similarity in dimensions and other characteristics of the trunk, most strikingly at the base. Also, the thickly waxy undersides of the leaves, their broad, thick-textured segments, and the large white scales on the rachis bracts, together with overall size and architecture of the inflorescences, are all features shared by both species.

\section{L. benthamii F.M. Bailey}

Bailey (1902: 1683); Beccari (1921: 14,18; 1931: 84, t.6iv); Burret (1941: 325); Blake (1954: 127, t.6, f.3-4); Specht (1958: 208, t.2C-D); Covacevich \& Covacevich (1978: 92); Johnson (1979: 13); Tucker (1980: 101); Jones (1984: 130). 
Type citation: 'Somerset, Cape York Peninsula, Frank L. Jardine' Dec 1897; holo BRI n.v. L. humilis R. Br., var. [nov.] F.M. Bailey, Queensland Agric. J. 2: 130 (1898) [same collection cited as for L. benthamii.]

L. holtzei Becc., Webbia 5(1): 18 (1921); Ann. Roy. Bot. Gard. Calcutta 13: 87 (1933).

Type citation: 'Australia boreale, presso Port Darwin (Holtze)'

Type: Northern Territory: Port Darwin, Holtze 1892?; FI, photos NSW, 4 sheets.

L. melanocarpa Burret, J. Arnold Arbor. 20: 190 (1939).

Type: Papua: Daru Island, Western Division, L.J. Brass 6310, 9 Mar 1936; iso BRI.

Trunk solitary, straight, to 17 or possibly $20 \mathrm{~m}$ high, 12-14 cm diameter in upper part, broadening gradually from about $5 \mathrm{~m}$ above ground in a long cone to $30 \mathrm{~cm}$ or more diameter just above roots. Surface becoming fairly smooth with age, obscurely patterned with sheath scars and petiole scars; vertical fissures numerous and regular but shallow; basal $5 \mathrm{~m}$ or so usually bearing persistent, patent or slightly deflexed petiole-stubs, these mostly $10-40 \mathrm{~cm}$ long.

Crown densely globose in adult state but greatly elongated in pre-flowering (frequently quite tall) plants, consisting of 30-50 ascending to spreading leaves with pendulous segment-lobes, the lower leaves slightly drooping. Ligules not seen but remnants on petioles pale grey-brown on both sides, abaxial side with dense but inconspicuous, closely appressed scales in deep pits.

Petiole (120-)160-180 (-210) cm long, 10-18 mm wide, roughly semi-circular in t.s. with slightly flared margins and 2 concave grooves either side of a median ridge above. Margins virtually unarmed on apical half except for few scattered blunt, very small prickles and scattered, minute brown calli; toward base armed with \pm closely spaced pungent, narrowly triangular-conical, patent to retrorse shiny brownish-black prickles to $6 \mathrm{~mm}$ long. Surfaces pale green, obscurely striate, clothed at first with whitish scales toward apex, these densely crowded above, to $1.5 \mathrm{~mm}$ long, very contorted and irregular, forming a deep spongy layer but soon marcescent, on lower side more appressed, crustose, inconspicuous; basal-masses persisting as minute conical red-brown pustules, hardly elongated. Hastula flat with upturned edges to semicylindrical; base broadly 2-lobed with shallow median notch or 3-lobed with lateral lobes wider than central; rim at $30-90^{\circ}$ to costa, variable in width, its margin early-necrotic and disintegrating.

Lamina moderately to strongly costapalmate with broad basal sinus, $70-115 \mathrm{~cm}$ long, 0.20-0.25 mm thick, chartaceous-coriaceous, moderately tough, moderately contorted with 2 adaxial undulations either side of the slightly deflexed costa and lowermost segments inflexed and erect, standing almost at right angles to petiole. Segments 29-39 either side of costa; largest segments $23-32 \mathrm{~mm}$ wide, broadening slightly toward point of bifurcation, free for $60-75 \%$ of their length, bifurcated for $50-65 \%$ of free length, the lobes slightly diverging, evenly tapering into soft, early-necrotic, acute but never aristate or threadlike apices. Intersegmental appendages lacking, or present only as very short remnants. Ribs: abaxial ribs in t.s. oblong with parallel faces, bluntly squared to somewhat rounded, $0.5-0.8 \mathrm{~mm}$ thick, c. $1 \mathrm{~mm}$ deep; adaxial ribs slightly smaller often tapering and rounded. Venation: major longitudinal veins 6-9 either side of abaxial rib, prominent above and below; transverse veins evident both sides but more prominent below, mostly at low angles to longitudinal veins, usually very crooked and minutely sinuous, frequently continuous across 3-4 major longitudinal veins. Surfaces olive-green, duller beneath, drying to pinkish-brown above contrasting strongly with greenish-brown beneath, glabrous except for few white chaffy scales on bases of ribs. 
Inflorescences shorter than petioles. Partial inflorescences c. 9, subequal, short relative to rachis; each branched to 2 further orders; rachillae (1-)5-12 cm long, $0.6-0.7 \mathrm{~mm}$ thick, reddish-brown (fruiting stage), finely and closely but shallowly striate, minutely but patchily strigose-pubescent with twisted, semi-appressed hairs, glabrescent post-anthesis but remaining minutely scurfy-papillose; larger axes similar but not pubescent. Rachis bracts flattened-cylindrical, the largest 20-22 mm diameter, smooth and tightly sheathing, very stiffly coriaceous and rather hard, pinkish-brown ageing to red-brown or greyish, finely but shallowly striate, patchily clothed with closely appressed silvery scales, these wearing off after anthesis leaving minute pustules as on petioles; bract apices triangular-ovate, smoothly acuminate. Flower-clusters $1-4 \mathrm{~mm}$ apart, 1-2(-3)-flowered; cluster axis $0.5-1.2 \mathrm{~mm}$ long, cylindrical or somewhat bulging. Cluster-bract caducous, evident (on specimens available) only as a narrow reflexed rim, if at all. Bracteoles not discernible.

Flowers (only seen post-anthesis, in early fruit stage) c. $1.5 \mathrm{~mm}$ long, possibly cup-shaped. Anthopodium 0.3-0.5(-0.8)mm long, wider than long, recessed at base and bluntly trigonous. Sepals very concave, membranous, thickening only close to base, $0.8-2.0 \mathrm{~mm}$ long, basally connate for $1 / 4-1 / 2$ their length; free portion triangular, acute. Petals slightly concave, thick and leathery, c. $1.3 \mathrm{~mm}$ long, connate for $1 / 6($ ?) their length, broadly triangular-ovate, acute or subacute, slightly mucronate, auriculate at base with relatively large, diverging auricles, inner faces with 2 deep narrow cavities close and parallel to margins. Stamens c. $9 / 10$ as long as petals, connate for $1 / 4-1 / 3$ their length; filaments thick, broadly triangular-ovate, gently rounded either side toward base, tapering smoothly to a slender apex; anthers (only 1 found) $0.33 \mathrm{~mm}$ long. Carpels almost as long as stamens; ovaries cylindrical, abruptly contracted into short slender styles.

Fruit obovoid-pyriform narrowing into prominent slender nipple at base, slightly flattened ventrally, 9-13 $\mathrm{mm}$ long, 9-11 mm diameter; usually with floral remains attached, the enlarged anthopodium and torus forming an extension c. $1 \mathrm{~mm}$ long. Epicarp blackish when ripe with thin glaucous bloom, quite smooth, thin and weak. Mesocarp c. $0.7 \mathrm{~mm}$ thick (dry), greenish and juicy when fresh, granular when dry. Endocarp $0.2 \mathrm{~mm}$ thick, horny but rather brittle, smooth and dark red-brown on inner face, outer surface with widely but irregularly spaced narrow longitudinal ridges. Seed subspherical or slightly ovoid, flattened ventrally, 8-9 mm long, 7-8 mm diameter; surface smooth and dark brown. Intrusion penetrating from lateral position for c. $1 / 2$ seed diameter, in 1.s. slightly lobed, occupying c. $1 / 3$ seed length; in t.s. more regularly 2-lobed with somewhat diverging lobes, occupying slightly over $1 / 3$ seed width. Embryo lateral (about 3 o'clock relative to stalk), showing as prominent dimple on seed surface. (Fig. 1a, 3e, 8a)

Distribution: Northern Territory, North Queensland, and southern Papua New Guinea: in the Northern Territory restricted to lower reaches of rivers and creeks draining north into the Arafura Sea and Van Diemen and Beagle Gulfs, also larger islands off the north coast; in North Queensland to Cape York Peninsula north of Iron Range, on lower reaches of coastal streams, mainly on east coast; in Papua New Guinea (as far as is known) to coastal lowlands on west shore of Gulf of Papua.

Ecology: occurs mostly in gallery-rainforest along sluggishly-flowing streams usually not far from tidal influence. In northwest Cape York Peninsula Tucker (1980) says it is 'Apparently confined to lagoon margins, moist gallery forests, and moister vine scrubs. It colonises the mangrove-vine scrub ecotone with much success and attains pure stand populations in several places. It extends inland where conditions permit.' My own limited observations suggest that it occupies similar habitats in the Northern Territory. However, on Elcho Island, NT, collectors' notes indicate that it grows in swamp forests dominated by Melaleuca. Near Oenpelli it grows on river flats 
apparently among eucalypts. It appears mainly to be found on depositional sands, silts and clays.

Conservation status: not considered at risk.

Specimens examined: Northern Territory: Darwin \& Gulf: Howard River, c. 3 km N of Howard Springs (23 km E of Darwin), Rodd 2904, 2905, 29 Oct 1974 (NSW, DNA, K); Howard River, Must 1150, 28 Aug 1973 (DNA, CANB); About S of Koolpinyah, Blake 16967, 10 Sep 1946 (BRI); Black Jungle, Darwin, Trapnell 105, 13 July 1958 (BRI); Oenpelli, Specht 1187, 14 Oct 1948 (BRI, MEL, AD, CANB); Jim Jim Ck, Jacobs 1790, 31 May 1974 (NSW); Obiri Rock, East Alligator River, Maloney 1978 (NSW 108859); Warangaiyu Lagoon, Elcho Is., Latz 6273, 19 July 1975 (DNA, CANB, NSW, BRI, K, L); Elcho Island, Maconochie 2119A\&B, 2234, 5 July 1975 (DNA, NSW, CANB).

Queensland: Cook: Bamaga District, Cape York, 'Long Scrub' 7 miles [11.3 km] NE of Bamaga on Jacky Jacky Rd, Webb \& Tracey 6122, 15 May 1962 (BRI); Jardine River, N bank, near crossing of Peninsula Development Rd, Hind 377, Oct 1974 (NSW).

Papua New Guinea: Western Division: Daru Island, Brass 6406, Mar 1936 (BRI); Upper Wassi Kussa River, Brass 8645, June 1936 (BRI). Central District: Brown River, alt. 100 ft, Millar NGF 38385, 20 Nov 1969 (BRI); 7 miles W of Kanosia Plantation, Darbyshire 685, 18 July 1962 (BRI); c. 6 miles SW of Karema, Brown River, Schodde 2677, 30 July 1962 (BRI); Waigani Swamp, alt. 200 ft, Gillison NGF 22018, 8 Dec 1964 (BRI).

\section{Notes}

1. This could be regarded as the least specialised Australian member of the genus, though possibly the apparent lack of specialisation of some characters is due to paedomorphy. Its leaves are thin-textured, quite non-glaucous, apparently mesomorphic; its slender inflorescences are less richly branched than other species of comparable stature, even down to the flower-clusters which are reduced to 1-2 flowers. Its preferred habitats are certainly more mesic than those of any other Australian species except perhaps for L. drudei. It shares with the latter (and with the sympatric L. muelleri) a fruit size at the bottom end of the range for Livistona, a feature doubtless related to the preferences of the fructivorous birds in such habitats.

2. An interesting gross feature of this species is its propensity to retain long, horizontally spreading petiole-stubs on the lower trunk. Although seemingly a specific character, it is possible that this is developed only in closed-forest habitats where there is protection from both fires and strong winds, allowing gradual decay of the persistent leaves. There is evidence for this in a large plant at Obiri Rock (photograph Maloney NSW 108859), where it is growing out in the open, probably in a fire-prone habitat, and showing a smooth, bare trunk.

3. Other distinctive morphological features are: (1) pubescent rachillae (shared only by L. humilis); (2) basal-masses of petiole, rib and lamina scales raised rather than sunken as in most other species; (3) the noticeably discolorous surfaces of dried leaves which become crinkled, and with a satiny sheen on both surfaces.

4. Beccari (1931) amplifies his 1921 protologue of L. holtzei: 'Discovered by Mr. Nicholas Holtz, at Glencoe Station which is about 100 miles from Port Darwin'. This was presumably based on his reading of a letter from Holtze to Mueller (28 November 1892), now held in FI, but a careful reading of the letter suggests that this was a misinterpretation. The Livistona specimen appears to have been, in fact, collected in the vicinity of Port Darwin. Blake's (1954) assignment of L. holtzei to the synonymy of L. humilis was based on his observation that only the latter species occurred at Glencoe.

5. Beccari did not allow for the occurrence of L. benthamii in the Northern Territory, though he believed his L. holtzei was closely related. The conspecificity of the Cape York and Northern Territory palms is perhaps open to slight doubt, since the material available from both areas is so fragmentary and largely juvenile and vegetative. 
However, there is a striking correspondence between them in growth-habit, in particular in the persistent petiole-stubs on the lower trunk, projecting horizontally. I have not been able to locate the type material of L. benthamii from Somerset, but Beccari's description of it corresponds well with my description above, except that the fruits are described as being only $8-10 \mathrm{~mm}$ long and 6-7 $\mathrm{mm}$ 'through', compared with 11-13 $\times 9-11$ as measured by me on the one fruiting collection available (Rodd 2904 from near Darwin).

6. Burret (1941) appears to have thought his L. melanocarpa almost certainly conspecific with L. benthamii, though regretting his lack of material for comparison. An isotype of L. melanocarpa held in BRI is identical in nearly all characters with material of L. benthamii from the Northern Territory. The only difference that might be regarded as significant is in fruit size. Fruits in a package attached to the sheet are quite small (about $7 \times 6 \mathrm{~mm}$ ) though apparently ripe. These dimensions are somewhat at odds with Brass's field notes, in which the fruits are described as ' $\pm 1 \mathrm{~cm}$ long'. However, in shape as well as mesocarp and embryo characters, the PNG and Australian fruits agree well enough. Brass's notes on growth habit and habitat are also consistent with L. benthamii in Australia, particularly his note 'lower half of trunk bristling with persistent horizontal leaf-bases $\pm 20 \mathrm{~cm}$ in length'.

7. The New Guinea specimen, Millar NGF 38385, has the label note 'fruit red when ripe'. However, the fruits on the specimen are small and very immature, being hollow when broken. The leaf (in BRI) is also small and very immature, barely hardened, but in characters of rachilla and floral remains, this material matches L. benthamii well. Some New Guinea specimens have longer leaves than have as yet been encountered in the relatively few adult collections from Australia, e.g. Brass 6310 has leaves $93 \mathrm{~cm}$ long, widest segment $28 \mathrm{~mm}$; Millar NGF 38385 has leaves $95 \mathrm{~cm}$ long, widest segment $27 \mathrm{~mm}$. Schodde 2677 has leaves $114 \mathrm{~cm}$ long, widest segment $27 \mathrm{~mm}$.

4. L. drudei F. Muell. ex Becc.

Beccari (1921: 15, 19; 1931: 89-90, t.6vii); Johnson (1980: 13); Jones (1984: 132); L. drudei F. Muell. nomen provisorium et subnudum Mueller (1878: 55, 147); Drude (1893: 55, 147 other notes give 1893: 11,12).

Lectotype (here chosen): Queensland: Rockingham Bay, Dallachy (?), Sep 1865. (MEL) [The lectotype is cited by Wendland \& Drude (1875) under 'L. inermis', together with a Thozet specimen from Rockhampton which is L. decipiens. Labelling of Dallachy's collection in MEL is very confused, with a slip in Dallachy's (?) hand saying 'Valley of the Mackay September 1865' plus field notes, whereas 'Rockingham's Bay' appears only on the seed packet, also with 'sept. 1865'. The material is clearly L. drudei which to the best of my knowledge does not occur anywhere near the Mackay River.]

[Livistona sp. 'Cooktown' (Jones 1984)]

Trunk solitary, to c. $20 \mathrm{~m}$ high, $15-20 \mathrm{~cm}$ diameter at $1 \mathrm{~m}$ above ground, broadening from a point c. $1.5 \mathrm{~m}$ above ground into a flared cone to c. $30 \mathrm{~cm}$ diameter sitting on a large root-mass up to $80 \mathrm{~cm}$ diameter and $40 \mathrm{~cm}$ high, reducing upward to a final constant diameter of c. 17-23 cm. Surface of old trunk pale grey, very smooth, waxy-whitish in patches, sheath scars barely discernible (but prominent on upper trunk); vertical fissures close, shallow, fine, not very prominent; petiole-stubs absent. Crown rather open, \pm globose, consisting of 30-60 leaves with long, weak, arching petioles, the lowest leaves radiating \pm horizontally or moderately pendulous but with petiole bases strongly ascending and imbricated, and pendulous segment-lobes. Ligules prominent, pale straw-coloured ageing dirty white, persisting as papery plates in upper half of crown, woolly-tomentose with narrow, deeply laciniate, contorted whitish scales. 
Petiole 160-230 cm long, 15-25 mm wide, flattened-triangular in t.s. with very rounded keel to unequally biconvex, with thin upturned edges. Margins virtually unarmed on upper half except for closely but irregularly spaced minute dark brown calli, grading randomly into pricklets; toward base armed with mostly retrorse, narrow, slightly falcate or sigmoid, pungent, shiny dark brown prickles to c. $7 \mathrm{~mm}$ long. Surfaces green, deep dull purplish toward base, \pm smooth, hardly striate, the upper with distinct median zone of fairly deep, narrow pits abruptly incised into surface, often obliquely oriented, closely crowded and frequently confluent, mostly empty of scales; the lower more closely and evenly pitted but pits shorter, broader, frequently confluent; scales when present whitish, very irregular, appressed, elongated, moderately thick, subentire, to c. $2 \mathrm{~mm}$ long, those on lower surface shorter. Hastula \pm flat or shallowly channelled, somewhat warped; base V-shaped and cuspidate to shallowly 3-lobed; rim at $25-35^{\circ}$ to costa, to $40 \mathrm{~mm}$ wide, subacute, entire except for (commonly) 1-2 deep clefts, up to $3 / 4$ of width necrotic.

Lamina $100-140 \mathrm{~cm}$ long, c. $0.2 \mathrm{~mm}$ thick, strongly costapalmate, somewhat elongated with the undissected portion rather long and narrow, the base \pm truncate or with broad sinus, fairly tough, not splitting readily; rather strongly contorted with 1 major and 1 smaller adaxial undulation either side of the almost straight costa and lower edges strongly involute, with lowermost few segments resupinate. Segments 33-35 either side of costa; largest segments $20-27 \mathrm{~mm}$ wide, free for $60-70 \%$ of their length, bifurcated for c. $60 \%$ of free length, the lobes moderately diverging, evenly tapering into finely attenuate but not threadlike, soft, flexuous, necrotic apices; in some specimens secondarily bifurcated to a depth of $8-15 \mathrm{~cm}$, the two parts of unequal width. Intersegmental appendages 5-10 mm long, somewhat stiff and brittle, white. Ribs: abaxial ribs in t.s. oblong or narrowing to lamina, bluntly square-edged to quite rounded, to $0.9 \mathrm{~mm}$ thick, $1.5 \mathrm{~mm}$ deep; adaxial ribs semi-elliptic to triangular, to 0.8 $\mathrm{mm}$ thick, $1.0 \mathrm{~mm}$ deep. Venation: major longitudinal veins 8-9 either side of abaxial rib, prominent above, less prominent below; transverse veins evident above, moderately prominent below, orthogonal to quite steeply angled, frequently arcuate or sinuous, mostly short, seldom crossing more than 1 longitudinal vein. Surfaces deep green, upper glossy, lower rather dull, quite glabrous except for inconspicuous pale brownish narrow scales on rib bases on underside.

Inflorescences slightly shorter than to longer than petioles, at most equalling petiole plus half lamina. Partial inflorescences 7-8, short relative to rachis, each branched to 3 further orders; rachillae $0.5-8 \mathrm{~cm}$ long, $0.5-0.8 \mathrm{~mm}$ thick, minutely pubescent with stiff antrorse hairs only c. $0.2 \mathrm{~mm}$ long, glabrescent post-anthesis, closely striate. Rachis bracts flattened-cylindrical, to c. $2 \mathrm{~cm}$ diameter, smooth but rather loose, coriaceous, rather tough, when dry pale yellowish-brown to darker reddish-brown, closely striate, sparsely sprinkled with minute white appressed scales, glabrescent post-anthesis; bract apices narrowly triangular, acute to slightly acuminate, variably fringed with narrow white scales. Flower-clusters $0.5-4 \mathrm{~mm}$ apart, 2-5-flowered; cluster axis $0.3-1.0 \mathrm{~mm}$ long, cylindrical to flattened, rather slender. Cluster-bract $0.5-1.0 \mathrm{~mm}$ long, triangular-acuminate or sparsely fimbriate, very delicately membranous except for fleshy base. Bracteoles approx. 1 per flower, similar to cluster-bract but shorter and often rounded.

Flowers c. $2.2 \mathrm{~mm}$ long, funnel-shaped. Anthopodium $0.2-0.3 \mathrm{~mm}$ long, cylindrical, rather slender, only slightly recessed at base. Sepals c. $1.5 \mathrm{~mm}$ long, connate for $1 / 3$ their length, appressed to petals, concave, membranous toward margins, free portion narrowly triangular-ovate, subacute. Petals $1.7-2.0 \mathrm{~mm}$ long, connate for $1 / 4$ their length, slightly concave, fleshy-textured; broad-ovate, acute to obtusish with very thickened apex, base with minute retrorse, rounded auricles; inner face with 2 deep, narrow cavities close to margins and a less distinct median cavity. Stamens c. $3 / 4$ as long as petals, connate for almost $1 / 2$ their length; filaments very fleshy, broadly ovate, hardly shouldered, abruptly narrowed into a quite short, slender apex; anthers 
$0.35 \mathrm{~mm}$ long. Carpels c. $3 / 4$ as long as stamens; ovaries obovoid-cylindrical, abaxially gibbous apically, narrowing rather abruptly into styles only c. $0.2 \mathrm{~mm}$ long.

Fruit \pm spherical or slightly pyriform, somewhat flattened ventrally, 10-12 mm long, 10-11 $\mathrm{mm}$ diameter (9-10 $\mathrm{mm}$ dorsiventrally). Epicarp dull purplish-black, finely rugulose. Mesocarp c. $0.4 \mathrm{~mm}$ thick, granular, rather dry and oily when fresh. Endocarp bony, rather brittle, straw-coloured, both surfaces smooth but dull. Seed ellipsoid-globose, flattened ventrally, 8-9 $\mathrm{mm}$ long, 7-8 $\mathrm{mm}$ diameter, surface dark brown. Intrusion penetrating from lateral position for slightly over $1 / 2$ seed diameter, in l.s. very slightly lobed but not apically dilated, occupying a little over $1 / 3$ seed length; in t.s. obscurely 2-lobed and slightly dilated, occupying c. $1 / 2$ seed width. Embryo lateral (c. 3 o'clock relative to stalk). (Fig. 3f, 8b)

Distribution: coastal northeast Queensland, scattered and discontinuous in coastal lowlands from the Kennedy River north-west of Cooktown south to Rollingstone Creek a short way northwest of Townsville, also on Hinchinbrook Island; additionally, I have seen and photographed palms that appear to be of this species around the estuary of the Proserpine River east-south-east of Proserpine, an occurrence separated by $1 \frac{1}{2}$ degrees of latitude and 2 degrees of longitude from what is otherwise its southern limit at Rollingstone Creek.

Ecology: chiefly a species of stream banks on flat coastal plains, mainly in bouldery alluvium, apparently confined to streams with a continuous dry-season flow or at least persisting as soaks. It occupies similar habitats above upper limit of mangroves beside sheltered estuaries. It occurs less commonly on hill-slopes, in clay soils on shale or siltstone. The vegetation types in which it occurs range from swamp-forest dominated by Melaleuca leucadendra to fringes of gallery-rainforest or tropical rainforest bordering on eucalypt forest dominated by species such as Eucalyptus tereticornis and Corymbia tessellaris.

Conservation status: $3 \mathrm{RC}-$. This coding is recommended in place of the code $3 \mathrm{VC}-$ assigned by Briggs and Leigh (1996) who treated the Cooktown populations as a separate undescribed species with a code 2 R (Briggs \& Leigh 1996).

Specimens examined: Queensland: Cook: Kennedy River $5.5 \mathrm{~km} \mathrm{~N}$ of New Laura Station, Irvine 2204, 26 Nov 1981 (QRS); Kennedy River, Irvine 2205, 26 Nov 1981 (QRS); 3.3 km off main road along road at north end of Cooktown Airport, Hind 4594, Hill \& Healy, 3 Aug 1986 (NSW). North Kennedy: North side of Herbert River, at SW base of Mt Leach Range, $14.5 \mathrm{~km}$ NW of Ingham, Rodd 3135 \& Jacobs, 17 May 1976 (NSW, BRI, K); at mouth of Herbert River, Webb \& Tracey 11176, (no date) (BRI); W.J. Huston's property 'Braemeadows' near Ingham, Thomas s.n., 27 Nov 1959 (BRI); Halifax, approx. 2 km along road to Lucinda, Irvine 1832, 9 May 1977 (QRS, NSW); Hen Camp Ck, Kinduro, near Bruce Highway, Irvine 1833, 1834, 9 May 1977 (QRS, NSW).

\section{Notes}

1. This species was known only as a somewhat shadowy entity until Beccari (1931) published an adequate description. In Wendland and Drude's (1875) account of Australian palms a broad concept of L. inermis was adopted, and this taxon appears to be the major element in their description. Mueller (1878) recognised this but chose to follow Bentham (1878) who placed tropical Queensland plants of this taxon under L. australis without comment. Bailey (1902) followed Bentham's treatment.

2. Mueller's epithet appeared only in the index of Fragmenta vol. 11, being only implied in the text and associated with L. australis, the question of its specific status being left open. Following upon some brief but arguably diagnostic descriptive and distributional comments, Mueller concluded: 'Huic palmae nunc pro speciei vel varietatis distinctione nomen Doctoris Oscaris Drude impono.' It is concluded that this name cannot be regarded as validly published by Mueller. 
3. The first subsequent mention of L. drudei is in Drude's long but disorganised paper on Australian Livistona, in which Mueller's assessment of its status is repeated ('Unterart oder Art?') but without any clear-cut pronouncement based on his own opinion. In his indented key to species Drude relates L. drudei to L. australis. His nesting it under L. australis without a number of its own suggests that it is given some sort of inferior status; on the other hand non-overlapping distributions are attributed to these taxa, implying separation. I conclude that Drude's (1893) treatment of L. drudei is still as a nomen provisorium at species rank.

4. The next use of this name is by Beccari, in his synoptical paper of 1921. Here, though the name is attributed to Mueller, it is clearly treated as a species, with an adequate diagnosis in the key. No specimens are designated, but there is a precise reference to Wendland and Drude's misapplied L. inermis ('non Rob. Br') as synonym, thus indirectly citing specimens from which the lectotype is here chosen.

5. Jones (1984) draws attention to populations of Livistona in Cape York Peninsula, as Livistona sp. 'Cooktown'; he cites the localities 'Flinders Island near Bathurst Bay, Kennedy River near Lakefield, tributaries of the Endeavour River and south towards Gap Creek near the Bloomfield River.' The only adequate collections I have seen from any of these localities are Irvine 2204 and 2205, both from the Kennedy River. I have examined these carefully and have concluded that these collections fall within the range of variation of L. drudei. Hind 4594 from near Cooktown consists only of a fallen dead leaf and old infructescence branch but the characters it exhibits all point to it belonging in L. drudei.

\section{L. australis (R. Br.) Mart.}

Martius (1838: 241-2); Hooker (1877); Mueller (1878: 55); Bentham (1878: 146); Moore \& Betche (1893: 427); Bailey (1902: 1684); Domin (1915: 501); Maiden (1921: 353, t.256); Beccari (1921: 18; 1931: 79-80); Evans \& Johnson (1962: 2); Moore (1963: 149; 1965: 148).

Corypha australis R. Br., Prodr.: 267 (1810).

Type: New South Wales: Port Jackson, Brown; holo BM; iso FI, photo NSW.

Trunk solitary, to c. $25 \mathrm{~m}$ high, 25-35 (-40?) cm diameter at $1 \mathrm{~m}$ above ground, broadening close to ground into a gently flared cone to c. $50 \mathrm{~cm}$ diameter, reducing upward for 5-7 $\mathrm{m}$ to a final constant diameter of c. $20-25 \mathrm{~cm}$. Surface rough but very regularly patterned, prickly with protruding fibres, with strongly stepped sheath scars; vertical fissures usually closely spaced, often branching, deep and gaping, often with criss-crossing fibres showing within; petiole-stubs absent from adult trunks. Crown moderately compact to rather open, \pm globose , consisting of 35-60 leaves with straight to gently arching or moderately drooping petioles and pendulous segment-lobes. Ligules moderately prominent, pale brown, patchily floccose with \pm appressed scales, margins irregularly fimbriate with fine, soft, straight, tapering scales to $8-10 \mathrm{~mm}$ long.

Petiole 140-250 cm long, 10-20 mm wide; t.s. concave-convex to roughly semi-circular, sometimes convex above and often with median ridge (sometimes 2 ridges). Margins unarmed except at base or with a few small, pungent, hooked prickles near apex and scattered minute, blunt teeth elsewhere; toward base armed with \pm closely and regularly spaced pungent, mostly retrorsely hooked blackish prickles to $2.5 \mathrm{~mm}$ long. Surfaces green, purplish-brown toward base, very finely and shallowly rugulose-striate; upper quite glabrous, sometimes irregularly pitted with narrow, elongated pits, lower rather closely pitted with obscure, shallow, short and broad to long and narrow pits, on young leaves bearing floccose scales to 3-4 $\mathrm{mm}$ long, usually pale brown, divided to base into several straplike but usually tightly twisted, branched laciniae; on older leaves usually only numerous minute, whitish to dark 
brown pustular, basal-masses with small scale-remnants persisting. Hastula cylindrical to flattened; base shortly but broadly 3-lobed, lateral lobes wider than central; rim at $10-90^{\circ}$ to costa, 5-30 mm wide usually with blunt peak at centre, with very narrow to broad necrotic margin.

Lamina 110-130 cm long, 0.15-0.25 (mostly 0.18-0.20) $\mathrm{mm}$ thick, moderately costapalmate, usually with narrow basal sinus or even with lower edges overlapping, chartaceous-coriaceous, moderately tough to rather brittle and readily split, moderately to strongly contorted with mostly 2 adaxial undulations either side of the moderately deflexed costa and lower edges sometimes involute with lowermost few segments resupinate. Segments (35-) 40-46 either side of costa; largest segments 28-49 mm wide, tapering slightly toward point of bifurcation, free for $54-62 \%$ of their length, bifurcated for $50-63 \%$ of free length, the lobes parallel or slightly diverging, evenly tapering into soft, acute but never aristate or threadlike apices, early-necrotic and frequently broken or split. Intersegmental appendages lacking even on the youngest expanded leaves, or rarely present as remnants to $3 \mathrm{~mm}$ long. Ribs: abaxial ribs in t.s. elliptic to trapeziform (narrowing to lamina), quite rounded to sharp-edged on one side only, rarely 2-angled though slightly rounded, $0.8-1.3 \mathrm{~mm}$ thick, $1.2-2.5 \mathrm{~mm}$ deep; adaxial ribs mostly rounded or sharp-edged on one side only, $0.6-0.8 \mathrm{~mm}$ thick, 1.4-3.0 mm deep. Venation: major longitudinal veins 7-10 either side of abaxial rib, moderately prominent above, slightly less prominent below; transverse veins evident to moderately prominent above, prominent below, fairly crowded, rarely steeply angled, finely sinuous and often also coarsely zigzagging or arcuate, frequently branched, most continuous across $1 / 2-3 / 4$ of each half-segment. Surfaces green, glossy, often with strong brownish tinge above, deep green beneath, closely striate between veins, quite glabrous except for ribs minutely punctate with brownish, pustular basal-masses, these stipitate on minute prickle-like stalks on adaxial ribs close to hastula; on young leaves bearing dense, floccose, pale brownish scales toward bases of ribs.

Inflorescences mostly shorter than petioles, occasionally equalling them. Partial inflorescences 6-9, subequal, the largest slightly over half total inflorescence length but with strongly recurving branches; each branched to $4(-5)$ further orders; rachillae 5-25 cm long, 0.7-0.9 mm thick, white when fresh, glabrous, minutely warty, wrinkled-striate when dry. Rachis bracts flattened-cylindrical, 4-5 cm diameter, often rather loose, warped, often wrinkled, very tough, whitish to pale purplish-brown when fresh, drying to deeper chestnut brown; \pm striate, sparsely to densely floccose-scaly, especially toward apex, scales usually pale brown, divided into several twisted, branched laciniae to $7 \mathrm{~mm}$ long; bract apices triangular, acute or slightly acuminate. Flower-clusters $0.5-3 \mathrm{~mm}$ apart, 1-4-flowered; cluster axis 0.5-2.0 $(-3.0) \mathrm{mm}$ long, cylindrical, moderately slender; longer cluster axes often with lateral flowers closer to base than apex. Cluster-bract $0.5-1.0 \mathrm{~mm}$ long, triangular-ovate, acute or sometimes rather jagged, appressed, membranous except for fleshy base. Bracteoles 1 per flower or sometimes an extra one present on 1-flowered clusters, similar to cluster-bract but shorter, mucronate.

Flowers $2.5-3.5 \mathrm{~mm}$ long, broadly funnel-shaped to rotate. Anthopodium $0.2-0.5 \mathrm{~mm}$ long, conical to cylindrical sometimes with slight constriction below calyx, minutely recessed at base with 3 obscure basal swellings. Sepals 1.2-2.1 mm long, connate for $1 / 3-1 / 2$ their length with very broad shallow sinuses, closely appressed to petals, moderately concave, membranous apically, fairly tough, broadly to narrowly triangular, subacute to acute. Petals $1.8-3.3 \mathrm{~mm}$ long, connate for $1 / 10-1 / 5$ their length, thick-textured, narrowly triangular to broadly oblong-ovate, bluntly acute to mucronate or almost rounded with thickened, sometimes hooded apex; auriculate at base with distinct retrorse, rounded to angular auricles; inner faces with 3 distinct, broad but rather shallow cavities. Stamens $5 / 6-7 / 8$ as long as petals, connate for $1 / 4-1 / 3$ their length; filaments thick and fleshy, broadly to narrowly triangular-ovate, hardly 
shouldered, tapering smoothly to somewhat abruptly into a slender subulate apex; anthers $0.5-0.7 \mathrm{~mm}$ long, the locules narrowly oblong (sterile?) to more broadly oval, often slightly displaced. Carpels $2 / 3-3 / 4$ as long as stamens; ovaries cylindrical to ovoid to obovoid and strongly gibbous apically, gradually to abruptly contracting into styles 0.2-0.4 mm long.

Fruit spherical, often slightly flattened ventrally, 13-22 $\mathrm{mm}$ diameter; suture often faintly visible; base sometimes extended into a very shallow cone, on stalk to c. $3.4 \mathrm{~mm}$ long consisting of thickened cluster axis topped by swollen anthopodium 0.9-1.5 mm long and 1.4-1.8 mm diameter. Epicarp deep reddish-brown to black, or black with brownish 'cheek', dull or with subdued satiny sheen, minutely verruculose and with sparsely and irregularly scattered pale brown circular spots $0.2-0.8 \mathrm{~mm}$ diameter often with central pore. Mesocarp 2-3 mm thick, olive green, firmly fleshy and hardly juicy when fresh; when dry granular with reddish-brown tannin-bodies, sparse thin fibres present, sometimes only adjacent to endocarp. Endocarp 0.2-0.3 mm thick, straw-coloured to pale brown, flexible but rather weak, mostly adhering to mesocarp; both inner and outer surfaces smooth but very minutely rough with loose spicular or papillose surface cells. Seed 11-16 mm diameter; surface pale brown, minutely rough and porous. Intrusion penetrating diagonally from sub-basal position for $1 / 2-3 / 4$ seed diameter, in 1.s. \pm oblong with broadly flared base, and rounded to shallowly 2-lobed summit, occupying $1 / 3-1 / 2$ seed length; in t.s. similar but less flared at base, occupying c. $2 / 5$ seed width. Embryo sub-basal, (4 to 5 o'clock relative to stalk). (Fig. 3g, 8c, 10)

Distribution: coastal eastern Australia south of $19^{\circ}$ lat. It extends southward from about the upper Noosa River (E of Gympie) in Queensland more or less continuously through New South Wales to near Batemans Bay but thereafter shows increasingly wide disjunctions until its last outpost in far eastern Victoria, close to the Snowy River mouth (see Note 6 below). Furthest inland occurrences observed are about $100 \mathrm{~km}$ from the sea in the upper Richmond and Clarence River basins, this distance diminishing southward, and at altitudes not exceeding about 500 metres. North of the Noosa River it is known from one small stand on Fraser Island (the common species on Fraser Island is L. decipiens), and thereafter only as widely disjunct occurrences in the Eungella-Crediton area near Mackay, and the southern Paluma Range-Keelbottom Creek area northwest of Townsville. Stands of palms which may well belong to this species have been sighted near the summit of Mt Elliot just south of Townsville, on Mt Dryander north of Proserpine, and on Mt Aberdeen west of Bowen. All these occurrences north of the Tropic are at altitudes between 500 and 1000 metres.

Ecology: occurs in a wide range of forest types, but most commonly in swamp-forest associated with species such as Melaleuca quinquenervia and Eucalyptus robusta, rainforest margins, or gallery-rainforest. In such wet situations it appears to be indifferent to soil type. Also found frequently on exposed slopes above the sea, principally on exposures of softer sediments, e.g. the Narrabeen Series close to Sydney, sometimes locally dominant on such sites. In some near-coastal areas it is common on valley-slopes in tall wet sclerophyll forest dominated by, e.g., Eucalyptus saligna and Syncarpia glomulifera, but is absent from such forests over wide regions. It is absent from all the 'rain shadow' reaches of coastal valleys such as those of the Hunter and Hawkesbury Rivers, though this may be due to incidence of destructive floods rather than insufficient moisture; isolated stands often occur in nearby tributary valleys in the mountain escarpment.

Conservation status: not considered at risk. Eungella and Paluma populations were listed as Livistona sp. 5 and sp. 6 respectively by Briggs and Leigh (1996) and given conservation codes of 2RC- but I consider these to be part of this widespread and abundant species (see note 4 below). 
Specimens examined: Queensland: North Kennedy: Paluma Range, Dotswood Holdings, $22 \mathrm{~km}$ west of Bluewater Creek on Forestry Road, Irvine 1928, 1929, 1930, 28 Jun 1979 (QRS, NSW); Bluewater Creek Forest Road about 22 km SW of Bruce Highway, Rodd 3758 E Lavarack, 24 Nov 1981 (NSW). South Kennedy: c. 2 km SE of Eungella on Broken River Road, Rodd 3073 \& Jacobs, 13 May 1976 (NSW). Wide Bay: Fraser Island, on margins of rainforest inland from Happy Valley on eastern side of island, Baxter 901, 4 May 1967 (BRI); $13 \mathrm{~km}$ E of Cooroy on Tewantin road, Rodd 3030 \& Jacobs, 6 May 1976 (NSW, BRI); about 4.8 km N of Nambour, Moriarty 671, 672, Aug 1971 (BRI). Moreton: Mooloolaba, c. 70 miles [113 km] N of Brisbane, Moore 9229 E Everist, 9 Feb 1964 (BRI, BH?); between Mt Glorious and Mt Nebo, Blake 21484, 15 Apr 1961 (BRI).

New South Wales: North Coast: Seal Rocks, 20 miles [32 km] E of Bulahdelah, Briggs s.n., 1 Aug 1964 (NSW); N of Ferny Creek, NW of 'Hut', W of Wallis Creek, Salasoo 3322, 6 Jan 1967 (NSW). Central Coast: 'Warra' (Univ. of Sydney Biological Field Station), Pearl Beach, Rodd 2672, 17 Jul 1974 (NSW); Bayview, Cabbage Tree Road, just inside W edge of golf course, Rodd 3615, 12 Dec 1980 (NSW); McCarrs Creek, Kuring-Gai National Park, Rodd 2671, 17 Jun 1974 (NSW); Kurnell, Botany Bay, Boorman s.n., May 1906 (NSW); above Garie Beach, Royal National Park, Rodd s.n., 28 Aug 1975 (NSW, QRS); Upper Kangaroo Valley, Rodd 2398, 27 Aug 1973 (NSW); Mt Cambewarra NW of Nowra, Constable s.n., 7 Dec 1950 (NSW). South Coast: 13 km from West Bodalla, Evans 96, 23 Jul 1976 (NSW); Tanja, on coast ENE of Bega, per Glenfield Vet. Res. Station, s.n., Jul 1954 (NSW); New Holland, Banks \& Solander 1770 FI n.v. photo NSW.

Victoria: Cabbage Tree Creek, Webb CBG 010319, 9 Mar 1965 (NSW).

\section{Notes}

1. This is the only Livistona occurring naturally south of $26^{\circ}$ latitude (except perhaps for $L$. decipiens and L. nitida whose southern limits are both very close to this parallel). Its southern limit at lat. $37^{\circ} 45^{\prime}$ in eastern Victoria makes it the second most southerly palm in the world after the New Zealand Rhopalostylis sapida.

2. A common species in the Sydney area, it is abundant on the south shore of Botany Bay, and was collected by Banks and Solander when Cook's first voyage reached this, its first Australian landfall, in 1770. No palm, though, is illustrated or even mentioned in the 'Illustrations of the Botany of Cook's Voyage Round the World', which suggests that even these intrepid botanists and their artist, Parkinson, gave little attention to such massive plants. However, there are specimens in BM and FI and a manuscript of Solander's in the British Museum (a copy of a page of which was kindly shown me by Mr D. McGillivray), summarising the species to be included in his never-completed manuscript flora. The names in it are mere provisional tags; four apparent palm names are listed, one being Corypha nuda from Botany Bay. It is likewise strange that no subsequent mention of this palm appeared in botanical or horticultural literature until Brown's 'Prodromus' was published in 1810.

3. Another puzzle is Brown's attribution of this species to the genus Corypha L., while at the same time erecting the new genus Livistona for L. inermis and L. humilis. The characters by which he differentiates these genera are very slight, amounting to little more than a small shift in embryo position. Brown was surely aware of Linnaeus's Corypha umbraculifera being typified (primarily) by Rheede's Codda-pana with its striking terminal inflorescence, but he may have preferred to characterise it by its other element, Rumphius's Saribus, which is the species now called Livistona rotundifolia. Against the latter interpretation is the separation by Lamarck in 1786 of the latter element as a distinct species, C. rotundifolia, in effect narrowing the application of Linnaeus's name to 'Codda-pana'. Brown's separation of the two tropical Australian species under a new genus (Livistona) was probably influenced by their different growth-habit and ellipsoid fruits, but these characters are not part of his generic diagnosis.

4. Jones (1984), quoting the observations and collections of A.K. Irvine, distinguished L. sp. 'Eungella Range' and L. sp. 'Paluma Range'. These were characterised as follows: 
'Eungella': 'The leaves of similar light green colouration on both surfaces, the broad central area of fused segments in the lamina'; 'Paluma': 'The leaf has a circular profile with a distinct sector at the base of the circle lacking segments; the lowest segments near the petiole are compound; the flowers are distinct with blunt petals which are held flat'. I have not as yet seen any convincing evidence that these populations differ in any significant respect from L. australis, but better flowering and fruiting collections may show characters by which they can be separated The foliage features noted by Jones may be associated with highly mesic or shady environments.

5. Orscheg and Parsons (1996a \& b), in an account of this species at its southern limit, present one of the most comprehensive ecological and phenological studies hitherto published of an Australian palm species. They point out, inter alia, the large disjunction of about $180 \mathrm{~km}$ between the only known Victorian stand (Cabbage Tree Creek near Orbost) and the next most southern stand a little north of Bega, N.S.W. and its very sparse occurrence from there north to Batemans Bay. A noteworthy observation was that fruiting trees flower at intervals of at least 2 years, with fruit ripening in the intervening year. The Victorian stand occurs in riparian forest dominated by Eucalyptus botryoides, a vicariant of the E. saligna and E. grandis that often accompany this palm further north.

6. Burret (1941) tentatively identified a palm collected by him in 1937 in the botanical garden at Rio de Janeiro as a hybrid between L. australis and L. chinensis var. subglobosa, but the evidence he presents for this conclusion is rather slender.

7. See '7. Evidence of dioecy (or androdioecy)' in the section 'Morphology and Terminology' (p. 70), for observations of sexual behaviour in this species.

\section{L. nitida A.N. Rodd, sp. nov.}

Palma magna L. australis affinis sed folia petiolis latioribus, partibus apicalibus vaginarum longioribus truncatioribusque, hastulis planioribus ad laminam appressioribusque; fructus magnitudines similes sed atro-nitidissimi, fibris mesocarpii densioribus crassioribusque, pagina interiore endocarpii ordinatione reticulata.

Type: Queensland: Junction of Dawson River and Delusion Creek, NW of Cracow, $25^{\circ}$ 11'S, 150¹1'E, A.N. Rodd 3055 E S. Jacobs, 9 May 1976; holo NSW; iso BRI, K, BH.

[Livistona sp. 'Carnarvon' (Jones 1984)]

Trunk solitary, to 25 or possibly $30 \mathrm{~m}$ tall, c. $30-35 \mathrm{~cm}$ diameter at $1.5 \mathrm{~m}$ above ground, gradually narrowing upward to c. $20 \mathrm{~cm}$ near crown on old plants, broadening below to a conical base c. $45-50 \mathrm{~cm}$ diameter. Surface ringed with sheath scars, obscure toward base but prominent and stepped higher up; vertical fissures numerous, regularly spaced, long and deep.

Crown globose, moderately dense, consisting of 35-50 strongly ascending to horizontally spreading to deflexed leaves with segment-lobes arching smoothly to abruptly with vertically pendulous tips. Ligules moderately prominent, pale straw-coloured, their margins patchily fimbriate with closely crowded, soft, hairlike brownish scales 10-15 mm long.

Petiole 170-190 cm long, 20-26 mm wide; flattened-triangular with smoothly rounded keel to almost semicircular in t.s, slightly convex to slightly concave above, usually with slight median keel. Margins virtually unarmed for most of their length, minutely crenulate with closely spaced, slightly raised brown calli and at wider intervals obscure blunt pricklets; at very base armed with \pm conical dark brown pungent prickles to $2 \mathrm{~mm}$ long, most antrorsely or retrorsely curved. Surfaces green, finely but shallowly striate; upper virtually glabrous, obscurely and sparsely pitted, with few appressed scales or scale remnants close to lamina; lower with scattered shallow, somewhat elongated pits, deeper and more crowded close to margins, bearing 
appressed, flat, \pm oval white scales under $1 \mathrm{~mm}$ long, their margins irregular but not fimbriate, soon deciduous leaving small but moderately conspicuous orange-brown basal-masses flush with petiole surface. Hastula base \pm truncate, shallowly 3-lobed, the central lobe shorter and narrower, acute; rim flattish, up to $6 \mathrm{~cm}$ long, \pm appressed to lamina, short- to long-triangular with broad, \pm entire necrotic margin

Lamina 160-190 cm long, 0.20-0.30 (mostly 0.25-0.28) mm thick, moderately costapalmate, truncate at base, coriaceous, moderately tough but fairly easily split, slightly to moderately contorted with 1 adaxial undulation either side of the slightly decurved costa, base on either side involute with lowermost few segments resupinate, or involute and then shortly revolute (S-shaped in 1.s., sometimes only on one side). Segments 34-38 either side of costa; largest segments 30-42 mm wide, narrowing slightly towards both point of bifurcation and basal sinuses, free for $63-70 \%$ of their length, bifurcated for $60-73 \%$ of free length, the lobes slightly diverging, evenly tapering, gradually attenuated into fine, soft but not threadlike, aristate apices, early-necrotic for final $10-20 \mathrm{~cm}$ but mostly remaining entire. Intersegmental appendages up to $60 \mathrm{~cm}$ long, \pm persistent, pale brown, glabrous, threadlike. Ribs: abaxial ribs in t.s. trapeziform (narrowing to lamina), sharply square-edged, 1.0-1.2 mm thick, 2.0-3.0 mm deep; adaxial ribs obliquely trapeziform, with one sharp edge, $0.7-0.9 \mathrm{~mm}$ thick, $1.2-2.0 \mathrm{~mm}$ deep. Venation: major longitudinal veins $7-9$ either side of abaxial rib, moderately prominent above, slightly more prominent beneath; transverse veins evident above, very prominent beneath, closely crowded, moderately to steeply angled, most strongly arcuate and/or sinuous, mostly continuous across whole half-segment and dendritically branched and/or anastomosing. Surfaces glossy bright green, somewhat yellowish above, beneath with suggestion of glaucousness on dried leaves (but waxiness not readily rubbed off), glabrous except for scattered whitish scales on ribs.

Inflorescences equalling or slightly exceeding petioles, strongly arching. Partial inflorescences 8-12, subequal, the longest slightly under half total inflorescence length, each branched to 4 further orders; rachillae 5-20 cm long, c. $0.8 \mathrm{~mm}$ thick, glabrous but whitish granular-papillose with age, obscurely wrinkled-striate; larger axes more prominently striate. Rachis bracts flattened-cylindrical, to $5-6 \mathrm{~cm}$ in diameter, tightly to rather loosely sheathing, frequently wrinkled, warped and torn, rich red-brown, shallowly striate with raised veins at regular intervals, sparsely to densely lanuginose-scaly with dirty-white tangled scales to $4 \mathrm{~mm}$ long, these stellately branched to somewhat plumose, the branches hairlike, contorted and twisted, each scale borne on a minute, forward-pointing, prickle-like stalk protruding from bract surface; bract apices rather narrow-triangular, acute to moderately acuminate, frequently split. Flower-clusters $0.8-3 \mathrm{~mm}$ apart, 2-4(-5)-flowered; cluster axis 0.5-1.5(-2.5) $\mathrm{mm}$ long, rather slender, longer ones with flowers scattered over their apical two-thirds. Cluster-bract c. $0.7 \mathrm{~mm}$ long, appressed to cluster axis, concave, oblong-ovate, acute, base persistent. Bracteoles 1 per flower with sometimes 1 empty one in addition, broad-ovate, concave, \pm fleshy, persistent at least as narrow rim.

Flowers (only 1 collection seen: Rodd 3055, with dead, semi-decayed flowers in advanced bud) c. $2.2 \mathrm{~mm}$ long, shape at anthesis not known. Anthopodium c. $0.5 \mathrm{~mm}$ long, 0.6-0.8 $\mathrm{mm}$ diameter, somewhat trigonous with 3 prominent downward bulges around the recessed base, usually constricted at junction with sepals. Sepals loosely appressed to petals, strongly concave, inflated, \pm membranous except along median line, c. $1.5 \mathrm{~mm}$ long, connate for $1 / 3$ to almost $1 / 2$ their length with very broad rounded sinuses, triangular-ovate, subacute., Petals thick-textured and leathery, strongly concave, $2.0-2.2 \mathrm{~mm}$ long, connate for c. $1 / \%$ their length, broadly obovate with bluntly acute, slightly mucronate apex, auriculate at base with small(?), rounded(?) auricles; inner faces with 3 large, distinct cavities. Stamens c. $4 / 5$ as long as petals, connate for c. $1 / 6$ (?) their length; filaments rather thin(?) and flat, ovate, not shouldered, smoothly tapering into a relatively long, slenderly aristate apex; anthers $0.42 \mathrm{~mm}$ long. 
Carpels c. $3 / 4$ as long as stamens; ovaries obovoid-cylindrical, strongly gibbous apically, very abruptly constricted into rather thick, straight styles c. $0.25 \mathrm{~mm}$ long.

Fruit spherical, to c. $17 \mathrm{~mm}$ diameter, often with slight basal protrusion, on stalk to $5 \mathrm{~mm}$ long consisting of greatly thickened cluster axis topped by swollen anthopodium to $2 \mathrm{~mm}$ long and almost $2.5 \mathrm{~mm}$ diameter. Epicarp jet-black, very smooth and glossy when fresh, drying to irregularly wrinkled with bluish waxy bloom. Mesocarp c. $2.5 \mathrm{~mm}$ thick fresh, greenish, fleshy, drying to c. $1 \mathrm{~mm}$ thick, containing numerous fairly crowded, moderately thick longitudinal fibres, concentrated mainly toward endocarp. Endocarp $0.20-0.25 \mathrm{~mm}$ thick, straw-coloured, rather hard and brittle, adhering closely to mesocarp in dried ripe fruit, its inner surface with a distinct regular pattern appearing reticulate to the naked eye, when magnified seen as small circles of radiating fine striations or minute, loosely attached fibres. Seed 10-12 mm in diameter, not flattened ventrally, pale brown finely speckled whitish except for deeper brown hilum. Intrusion penetrating \pm diagonally from well below median position for c. $2 / 3$ seed diameter, in l.s. half-dumbbell shaped, occupying less than $1 / 2$ seed length, in t.s. very similar. Embryo at or slightly above median position (2 to $3 \mathrm{o}^{\prime}$ clock relative to stalk). (Fig. $2 \mathrm{a}-\mathrm{b}, 3 \mathrm{~h}, 8 \mathrm{~d}, 9 \mathrm{~b}-\mathrm{c}$ )

Distribution: subcoastal southeast Queensland, confined to the upper Dawson River basin and the uppermost Comet River basin, within an area bounded approximately by Moura and Rolleston to the north, Wandoan and Injune to the south, the Great Dividing Range to the west, and Auburn Range to the east. This region is approximately $350 \mathrm{~km}$ WNW of Brisbane and covers approximately 2 degrees of latitude and 2 of longitude; the downstream limit on the Dawson is not known to me with certainty. The species is abundant at Theodore but is not evident where the Dawson Highway crosses the river west of Moura. I am informed by Peter Hind that there is a population of Livistona in Cania Gorge, about $30 \mathrm{~km}$ NW of Monto, which may be this species and which would extend its range into the Burnett River catchment.

Ecology: confined to banks and channels of larger, semi-permanent streams, in sandy, silty or gravelly alluvium; also at cliff-bases and on cliff-ledges in sheltered sandstone gorges, most notably in Carnarvon Gorge. In the eastern part of its range it is mostly found associated with Eucalyptus tereticornis and E. microtheca s. lat., but to the west (Carnarvon Range, Great Dividing Range) it is frequently associated with E. tereticornis, E. melanophloia, Corymbia maculata, C. citriodora, Angophora floribunda and Macrozamia moorei.

Conservation status: 2RC-(Briggs \& Leigh 1996, as Livistona sp. 3: Carnarvon \& Taroom)

Specimens examined: Queensland: Leichhardt: Cracow-Theodore road on Delusion Creek about 12 miles [19 km] N of Cracow, Johnson 847, 28 June 1959 (BRI); Junction of Dawson River and Delusion Creek, NW of Cracow, Rodd 3051, 3052, 3054, 3055 \& Jacobs, 9 May 1976 (NSW, BRI, K, BH); Palm Tree Creek 19 km N of Taroom, Telford 5648, 7 June 1977 (CBG, NSW); Palm Tree Creek c. $12 \mathrm{~km}$ from Taroom on Taroom-Theodore road, Moriarty 1280, 15 May 1973 (BRI); Robinson Creek and Palm Tree Creek, Taroom, Stiller s.n., 16 Sep 1960 (BRI); Robinson Creek 10 miles [16 km] NW of Taroom, Leichhardt District, Speck 1986, 3 May 1964 (CANB, BRI); Carnarvon Creek, near entrance to Carnarvon Gorge National Park, Rodd 1112, 12 Aug 1970 (NSW).

\section{Notes}

1. This species is distinguished from L. australis on rather slight characters, but these appear to be fairly constant and reliable over the whole area of its occurrence.

2. The specific epithet, meaning 'shiny', refers to its most distinctive feature, viz. the highly glossy surface of the ripe fruits, in contrast to the dull, minutely rugulose fruits of L. australis. Internal features of the fruit also serve to distinguish it: the mesocarp has more numerous, thicker fibres, and the endocarp is thicker, its inner face displaying an unusual reticulate pattern. In vegetative characters the only striking differences from 
L. australis are the shape and length of the ligules; good specimens of these organs, however, are represented in only one collection each of these two species, both obtained by felling an adult tree and dissecting the crown. Other foliar differences are more subtle, the most apparent being the slightly wider petiole and flatter, more appressed hastula in L. nitida; the undulation of the lamina is possibly also less pronounced than in L. australis.

3. Growth-habit is strikingly similar to that of L. australis, also trunk dimensions and surface characters. It is possible, though, that L. nitida attains a greater height than any other Australian species: the magnificent stand at the junction of Delusion Creek and the Dawson River includes individuals which, by a visual estimate, possibly exceed 30 metres.

4. For approximately the last $30-40$ years this has been recognised as a distinct but unnamed species in the Queensland Herbarium; the late Dr S.T. Blake was the first to treat it as such. Previously its populations were doubtless treated as L. australis (just as were those of the far more distinctive L. decipiens), though I have not come across any record even of the existence of palms in the Dawson River basin from earlier than the 1960s.

\section{L. decipiens Becc.}

Beccari (1910: 301, fig. 1, t. II; 1921: 18; 1931: 81, t.6II); Moore (1963: 150); Johnson (1980: 13); Blombery \& Rodd (1982: 123); Jones (1984: 131).

Lectotype (chosen here): [cultivated] A. Robertson-Proschowsky s.n., May 1908 (sheet with older inflorescence) (FI, photo NSW). Syntypes: cultivated Nice, France, A. Robertson-Proschowsky s.n., Sep 1908 (leaf) (FI, photo NSW); A. Robertson Proschowsky s.n., Sep 1907 (fruits) (FI, photos NSW).

L. decipiens var. polyantha Becc.

Beccari (1921: 15,18; 1931: 82).

Type: cultivated Bot. Garden Buitenzorg (now Bogor), Java; holo FI (two sheets), photo NSW; ?iso BO.

Trunk to c. $10 \mathrm{~m}$ tall, c. $25 \mathrm{~cm}$ diameter at $1 \mathrm{~m}$ above ground, reducing to c. $20 \mathrm{~cm}$ diameter toward top, widening below (from c. $0.5 \mathrm{~m}$ above ground) into a gently flared cone up to c. $35 \mathrm{~cm}$ diameter at base. Surface moderately smooth but with prominent annular sheath scars; vertical fissures numerous, fine, scattered; petiole-stubs frequently present on lower 1-2 m of trunk, closely appressed, to c. $10 \mathrm{~cm}$ long.

Crown globose or frequently broader than deep, moderately dense, consisting of 30-60 leaves with fairly straight, rigid petioles, the leaf-blades spreading rigidly to the point of bifurcation of their segments but with lobes vertically pendulous producing a curtain-like effect. Ligules not very prominent, pale reddish-brown aging to dirty white; shredding into fibres at early stage leaving only remnants of unshredded apex, its margin sparsely fimbriate with long slender white scales, its outer surface with close network of strongly raised fibre-bundles and scattered, inconspicuous, contorted, appressed translucent scales.

Petiole $160-280 \mathrm{~cm}$ long, $18-24 \mathrm{~mm}$ wide; flattened-triangular in t.s. with bluntly angular to rounded keel, slightly convex to slightly concave above sometimes with slight median ridge. Margins virtually unarmed over most of petiole length or with scattered, small, mostly antrorsely curved, pungent prickles; toward base with closely and rather evenly spaced, slender, shiny dark brown pungent prickles c. $4 \mathrm{~mm}$ long, retrorse or patent or mixed antrorse-retrorse. Surfaces finely rugulose-striate, upper with sparse, shallow pits, in 2 rows either side of centre, containing inconspicuous, early-deciduous scales; lower with more numerous, poorly defined, often confluent 
pits, densely but not completely covered in crustose, dirty white scales, these roughly circular, c. $1 \mathrm{~mm}$ long, quite thick but with flat, shaggy surface, dotted with minute reddish tannin-bodies, margins shortly fimbriate; persistent basal-masses very minute, slightly elongated, flush with surface or very slightly raised. Hastula base broadly 3-lobed, the centre lobe longest, acute; rim almost parallel to costa, very ragged on fully expanded leaf, 3-lobed, the centre lobe 8-15 cm long, lateral lobes much shorter, their outer edges adnate to lowermost segments of lamina; necrotic margin conspicuous, brittle, fragmenting.

Lamina $130-180 \mathrm{~cm}$ long, $0.20-0.25 \mathrm{~mm}$ thick, strongly costapalmate, elongated, dissected virtually to base into slender radiating segments, (palman very elongated and extremely narrow in upper part, forming a mere narrow wing on either side of costa), coriaceous, moderately tough, splitting readily, the whole lamina very strongly contorted with 2 adaxial undulations either side of the slightly recurved costa and lower edges inflexed with lowermost 8-11 segments resupinate and again reflexed to give an S-shaped section. Segments 35-42 either side of costa; largest segments 26-34 mm wide just below point of bifurcation, narrowing toward bases to $18-25 \mathrm{~mm}$, free for $82-88 \%$ of their length, bifurcated for $44-54 \%$ of free length, the lobes slightly diverging and drooping from base to a vertically pendulous attitude, tapering evenly to soft, shredded, early-necrotic apices. Intersegmental appendages up to $8 \mathrm{~cm}$ long, fine, somewhat brittle, threadlike, dull purplish at tips, few persisting on older leaves. Ribs: abaxial ribs in t.s. oblong-elliptic to trapeziform-obovate (narrowing to lamina), bluntly square-edged to rounded, $0.8-1.5 \mathrm{~mm}$ thick, $1.5-3.0 \mathrm{~mm}$ deep; adaxial ribs trapeziform, broadest at lamina, bluntly to somewhat sharply squared at summit, c. $1.3 \mathrm{~mm}$ thick, $1.3 \mathrm{~mm}$ deep. Venation: major longitudinal veins 7-8 either side of abaxial rib, prominent above, less prominent beneath; transverse veins evident but not prominent above, moderately prominent beneath, rather crowded, nearly all angled but most not steeply, most arcuate or sinuous, most continuous across at least 1 longitudinal vein, many across 2-5. Surfaces green, upper glossy and slightly yellowish, quite glabrous, lower duller green with very thin, virtually invisible waxy bloom, glabrous except for scattered whitish scales on ribs.

Inflorescences from shorter than petioles to exceeding petioles by half lamina length, erect and arching or arching to below horizontal even in flower; rachis very stout. Partial inflorescences 8-12, markedly distichous, all \pm equal in size, the larger axes sinuous in a horizontal plane; branched to 4 further orders; rachillae 5-20 cm long, 0.5-0.7 mm thick, wrinkled-striate, glabrous but minutely granular-papillose, pale to dark red-brown by fruiting stage; larger axes similar, sometimes with bands of woolly, slender scales on inner faces of 1st-order branches, otherwise glabrous. Rachis bracts flattened-cylindrical to obscurely trigonous, broadening toward their apices, up to $4 \mathrm{~cm}$ diameter, somewhat loose, transversely wrinkled and warped, larger ones often stretched and rent into fibres near apex, very stiff and hard-textured, finely rugulose-striate toward apex, glabrous except for dusting of fine whitish granular papillae toward apex, greenish right up to fruiting; bract apices ovate, shortly acuminate, necrotic, greyish to red-brown. Flower-clusters $0.7-5 \mathrm{~mm}$ apart, racemosely (2-)3-6-flowered; cluster axis $0.3-5(-6) \mathrm{mm}$ long, c. $0.25 \mathrm{~mm}$ thick at flowering, bearing flowers most of its length. Cluster-bract c. $0.5 \mathrm{~mm}$ long, narrow, acuminate or fimbriate with very delicate, early-deciduous apical portion, thickened across base. Bracteoles 1 per flower, short, broad, appearing as narrow rim even at early flowering stage.

Flowers c. $2.0 \mathrm{~mm}$ long, probably funnel-shaped (only seen at very early anthesis). Anthopodium slender, c. $0.5 \mathrm{~mm}$ long with base oblique, junction with cluster axis slightly recessed, with narrow sharp rim. Sepals forming a loose, somewhat inflated cup around petals, membranous, thickening gradually to base, $1.3 \mathrm{~mm}$ long, connate for at least $2 / 5$ their length, ovate-triangular, obtuse. Petals thin-textured but tough, slightly concave, $1.8 \mathrm{~mm}$ long, connate for c. $1 / 3$ their length, broadly ovate, broadly 
acute, slightly thickened and inflexed at apex, auriculate at base with rounded, broadly overlapping auricles; inner faces with two large, shallow cavities adjacent to margins and a smaller cavity beneath thickened apex. Stamens c. $5 \%$ as long as petals, connate for c. $1 / 3$ their length; filaments thin and flat, strongly shouldered, tapering smoothly but at wide angle into very short subulate apex; anthers $0.35 \mathrm{~mm}$ long. Carpels almost as long as stamens; ovaries obovoid, strongly gibbous abaxially, narrowing fairly abruptly into styles c. $0.35 \mathrm{~mm}$ long.

Fruit spherical, 13-15 mm diameter, perfectly rounded at base and apex, on stalk up to $9 \mathrm{~mm}$ long consisting of crooked, enlarged cluster axis of variable length, plus enlarged conical anthopodium to c. $2 \mathrm{~mm}$ long, plus greatly swollen floral torus (between sepals and petals) c. $1 \mathrm{~mm}$ long and $2 \mathrm{~mm}$ diameter. Epicarp black, smooth and shiny when fresh, closely wrinkled when dry. Mesocarp 1-1.5 mm thick, soft and fleshy but toward endocarp containing a close reticulum of flattened fibres, very conspicuous in old fallen fruits. Endocarp c. $0.15 \mathrm{~mm}$ thick, closely adhering to seed where it persists after fruit decays, outer surface smooth, pale brown. Seed spherical, c. $10 \mathrm{~mm}$ diameter, shiny dark brown. Intrusion penetrating from lateral position for $2 / 3$ width of seed, in 1.s. shallowly 2-lobed, slightly dilated apically, occupying $1 / 2$ seed length, in t.s. similar but occupying less than $1 / 2$ seed width. Embryo sub-lateral (c. 4 o'clock relative to stalk). (Fig. 2d, 3i, 9d, 11)

Distribution: east-coastal Queensland from latitude 19 ${ }^{\circ} 30^{\prime}$ (approx.) to $26^{\circ}$, i.e. from just south of Townsville to the northern end of Cooloola National Park, south-east of Maryborough. Distribution is semi-continuous over much of this range, with only minor gaps; it is apparently restricted to a narrow lowland zone, extending inland no further than about $50 \mathrm{~km}$ and onto bases of hills up to no more than 100-200 $\mathrm{m}$ altitude.

Ecology: most commonly found along banks of rivers and smaller streams, on alluvial deposits; in some areas found also on gentle to steep hillsides, on clay soils derived from shales or skeletal soils over igneous rock; also near seashore in sheltered hind-dune hollows and swampy depressions. Mostly associated with margins of gallery-rainforest or dry rainforest or extending a little into open-forest dominated by Corymbia tessellaris or Eucalyptus tereticornis, sometimes in swamp-forest with Melaleuca leucadendra or M. quinquenervia and Eucalyptus alba.

Conservation status: not considered at risk.

Selected specimens examined: Queensland: North Kennedy: West Baratta Creek, Bruce Highway, between Ayr and Giru, Rodd 3117, 14 May 1976 (NSW); 51 miles [82 km] S of Townsville, Trapnell 305, 20 July 1960 (BRI); Bruce Highway, a few km N of St Margaret Creek between Ayr and Townsville, Moriarty 767, 21 May 1971 (CANB, BRI); Haughton River near Bruce Highway, Irvine 1818, 21.1.1977 (QRS). South Kennedy: Palm Creek, Bruce Highway, North Kennedy District, Briggs 2071, 8 Aug 1968 (NSW); 10 km W of Mackay on bypass road, Rodd 3075, 13 May 1976 (NSW); E of Dingo Beach road on 'Earlando' Beach turn-off, c. $35 \mathrm{~km}$ NNE of Proserpine, Rodd $3077 \mathcal{E}$ Jacobs, 13 May 1976 (NSW, BRI). Port Curtis: between Byfield and Maryvale in forest, White 8197, 25 Sep 1937 (BRI); Yeppoon-Emu Park road, c. 11 km S of Yeppoon, Rodd 3069 E Jacobs, 12 May 1976 (NSW, BRI, K, BH); Joskeleigh, about 15 miles [24 km] E of Rockhampton in sandy, swampy soil c. $1 / 2$ mile $[0.8 \mathrm{~km}$ ] from beach, Everist 7634, 17 Mar 1964 (BRI, K); Moore's Creek Range near Rockhampton, Thozet s.n., (before 1875) (MEL); near Bustard Bay (S.F. 86 Eurimbula), Cooper s.n., July 1966 (BRI); between Agnes Water and Round Hill Head, S of Bustard Bay on coastal dunes, Everist s.n., 28 Mar 1970 (BRI); Agnes Water, $40 \mathrm{~km}$ E of Miriam Vale, McDonald 1224X \& Batianoff, 4 Apr 1975 (BRI); Palm Creek, 8 km S of Miriam Vale, Bruce Highway, Hind 257, Aug 1973 (NSW); Reedy Creek, 8 km SE of Lowmead on Bundaberg road, Rodd 3045 \& Jacobs, 8 May 1976 (NSW, BRI). Wide Bay: Cooloola State Forest ENE of Gympie, Moriarty 668, 668A, 669, Apr 1971 (BRI).

Cultivated: Bogor, Java, C.X. Furtado, Singapore Field No. 30948, Gardens No. XII.E.91, iv-v.1936 (BRI). 


\section{Notes}

1. In his protologue paper (in Italian) Beccari recounts how this palm was known in a number of gardens in the Riviera, under the name 'Copernicia cerifera' and that some palm collectors realised that this name could not be correct. He quotes at length from a letter written to him by B. Chabaud di Tolone, who reported that this identification had originated from (the late) Nabonnand, 'rosieriste au Golfe Juan', who had two healthy specimens $2.5 \mathrm{~m}$ high in his garden in 1883. Chabaud, however, had the same palm growing, but his originated from seed sent to him by von Mueller under the name Livistona humilis. He mentions another grower, the Comte d'Empremesnil, who likewise had it as L. humilis.

2. From the above, it seems likely that all these cultivated plants originated from the one source. One might plausibly surmise that this source was Thozet, who sent to von Mueller a specimen of this species he had collected at Moores Creek Range, Rockhampton, before 1875. According to Hall (1978), Thozet, who lived in the Rockhampton area from 1858 to his death in 1878, sent most of his specimens to von Mueller in Melbourne, 'but was also active in making Australian plants known in France'. It is possible, even likely, that Thozet made repeated collections of this species, which is reasonably frequent in the Rockhampton area, for distribution overseas.

3. It is puzzling that this species should have become relatively common in the Riviera by the late 19th century, yet unknown in cultivation in Australia right up to the 1950s. Beccari's correspondent Robertson-Proschowsky noted that it throve in his garden at Nice, growing faster than L. australis and very much faster than L. chinensis, though he considered it less ornamental than either on account of its 'leaf divisions hanging like narrow strips around the end of the petiole giving it the aspect somewhat of a mass of rags' (my translation).

4. Beccari (l.c.) believed that his L. decipiens originated from temperate eastern Australia, basing this notion largely on a specimen (consisting only of a leaf) sent to him by Ewart, collected by E. Reader from Mt Dromedary, New South Wales. This, Beccari considered, could not be $L$. australis by reason of its segments 'profondissimamente divisi in lunghe lacinie pendenti' which feature he regarded as characterising $L$. decipiens. I have not seen this specimen, but present knowledge gives no reason to doubt that L. australis is the only species present in New South Wales.

5. Var. polyantha Becc. was distinguished from typical L. decipiens by its smaller flowers in clusters of 3-5 at apices of 'pedicels', and smaller fruits. In his 1921 protologue Beccari gives simply 'Buitenzorg' (cultivated in botanic garden) as its origin, but in his monographic 1931 treatment he is more specific, nominating its source as 'XII E. 91 position in the Garden; No. 408 of the Herbarium'. In BRI there is a good specimen collected in Bogor by Furtado in 1936 from a plant 50-70 feet [c. 15-20 m] tall, 'Gardens No. XII.E.91'; there seems little doubt that this is the type plant of var. polyantha, and it falls comfortably within the range of variation of the wild species. In FI there are two sheets (one with leaves and the other with an inflorescence) labelled 'No. 908 Herb. Hort. Bot. Bog.' and 'XII E 91' plus 'Livistona decipiens Becc.' — the herbarium number is hand-written and looks more like '908' than '408'.

6. L. decipiens is a species readily recognisable in the field by its very large but very deeply dissected leaves; dissection is mostly to within $8 \mathrm{~cm}$ of the hastula and within $3 \mathrm{~cm}$ of the costa in its upper half. Another striking feature is best exhibited by fruiting specimens, viz. longer cluster axes than any other Australian species, up to $9 \mathrm{~mm}$ in fruit; in flower the cluster axes are considerably shorter but very slender, with flowers racemosely arranged. Fruits are distinctive by their well-developed, crowded inner mesocarp fibres. 
7. The only species it is likely to be confused with is L. drudei, which comes close to it geographically, but this has less deeply dissected, smaller leaves, much shorter cluster axes, and slightly pyriform, smaller fruits, apart from differences of indumentum and growth-habit.

\section{L. fulva Rodd, sp. nov.}

Palma solitaria magnitudine mediocris, trunco ad $13 \mathrm{~m}$ alto, c. $25 \mathrm{~cm}$ diametro. Coma globosa, sparsa foliis rigide radiantibus petiolis ultra $2 \mathrm{~m}$ longis, c. $14 \mathrm{~mm}$ latis proxime laminam; laminae c. $1 \mathrm{~m}$ longae, dissectae ad c. $1 / 2$ totarum longitudinum, segmentis grandioribus c. $40 \mathrm{~mm}$ latis brevissime bifurcatis. Inflorescentiae quam petiolis breviores, 6-9 ramis lateralibus, illis denuo 4-plo ramosis, rhachillis $5-16 \mathrm{~cm}$ longis, c. $0.7 \mathrm{~mm}$ diametris. Flores $1-3$ fasciculis sessilibus. Fructus globosus, niger, pruinosus, c. $15 \mathrm{~mm}$ diametro. Semen ad $12 \mathrm{~mm}$ diametro, intrusioni testae laterali, embryone laterali.

Type: Queensland: Blackdown Tableland, just below escarpment at NE end (road pass), $23^{\circ} 43^{\prime} S, 149^{\circ} 07^{\prime} E$, alt. 4-500 m, A.N. Rodd 3062 E S.W.L. Jacobs, 11 May 1976; holo NSW; iso BRI, K, BH.

[Livistona sp. 'Blackdown' (Jones 1984)]

Trunk solitary, to $13 \mathrm{~m}$ high, $20-25 \mathrm{~cm}$ diameter at $1 \mathrm{~m}$ above ground, below usually broadening gently at base to perhaps $30 \mathrm{~cm}$ diameter at ground. Surface closely ringed with stepped sheath scars, rough-textured with prickly fibres; vertical fissures numerous, regularly spaced, deep and gaping, some $10 \mathrm{~cm}$ or more long; petiole stubs absent.

Crown rather open, hemispherical to somewhat more globose, consisting of c. 35 mostly spreading, flattish leaves with long, arching petioles, the lowest drooping to not much below horizontal or less commonly to a steeper angle. Ligules moderately large, pale straw-brown, their margins with finely laciniate soft teeth c. $10 \mathrm{~mm}$ long, outer surfaces appressed-tomentose with twisted, hair-like whitish scales.

Petiole 200-250 cm long, c. $14 \mathrm{~mm}$ wide; roughly semi-circular in t.s., the upper side with a concave groove either side of a pronounced median ridge. Margins unarmed on apical half at least, with only occasional small, dark-coloured bumps and more frequent minute calli, these with a slightly sunken, elongated dark brown centre; near base armed with closely-spaced retrorse, slightly sigmoid, slender, very pungent blackish prickles up to $10 \mathrm{~mm}$ long. Surfaces both yellowish-green, closely striate especially in furrows on upper side, thinly clothed in appressed, translucent, hair-like scales with rows of red-brown tannin-bodies giving them an orange cast, soon glabrescent leaving persistent, densely crowded but very minute dark brown basal-masses, sparser but slightly larger and elongated, slightly raised, on underside. Hastula base \pm truncate; rim at approx. $90^{\circ}$ to costa, to $4 \mathrm{~cm}$ or more wide, flattish in middle part but lateral parts inflexed abruptly at an acute angle, early-necrotic and disintegrating into irregular narrow ribbons. Rudimentary abaxial hastula present, as cuspidate to long-acuminate, narrow dark-coloured rim projecting from costa as a slight step.

Lamina 90-100 cm long, $0.2 \mathrm{~mm}$ (or slightly more) thick, weakly costapalmate, \pm circular in outline, chartaceous-coriaceous, moderately tough and flexible, virtually flat to slightly contorted with 1 broad, gentle adaxial undulation either side of the slightly deflexed costa and lowermost segments slightly involute. Segments 30-33 either side of costa; some lower segments partially fused into 2-3-ribbed compound segments with primary sinuses displaced to near their apices; largest segments 35-40 $\mathrm{mm}$ wide, widest at base, free for $50-55 \%$ of their length, bifurcated for at most a few $\mathrm{cm}$, the lobes of the apical few segments usually rounded, diverging, often slightly hooked, $0.5-1 \mathrm{~cm}$ long, of other segments \pm parallel, acute to obtuse, 1-5 cm long. Intersegmental appendages present only at early stages, very fine, weak, threadlike, to 
c. $6 \mathrm{~cm}$ long, breaking off to leave an occasional small remnant on older leaves. Ribs: abaxial ribs in t.s. \pm oblong, bluntly square-edged to quite rounded, c. $2 \mathrm{~mm}$ deep, $0.9 \mathrm{~mm}$ wide; adaxial ribs oblong to elliptic, mostly rounded, c. $0.7 \mathrm{~mm}$ wide, $1.5 \mathrm{~mm}$ deep. Venation: major longitudinal veins 7-10 either side of abaxial rib, prominent on upper surface, somewhat obscure beneath; transverse veins evident above, more prominent beneath, most near-orthogonal with respect to longitudinal veins, most arcuate, sigmoid or sinuate and continuous across 2-4 longitudinal veins. Surfaces: upper glabrous and slightly greyish green with slight satiny gloss; lower paler bluish-green, on newly expanded leaves partially masked by conspicuous orange-brown indumentum, this finely and closely floccose-tomentose consisting of thin translucent scales with densely tangled fimbriate margins and flecked profusely with orange-brown tannin-bodies, their basal-masses raised, slightly elongated, also orange-brown and persisting after scales fallen; both surfaces finely and quite deeply striate.

Inflorescences a little shorter than petioles. Partial inflorescences 7-9, closely spaced, subequal, the largest approximately half as long as total inflorescence, moderately deflexed with pendulous rachillae, each branched to 4 further orders; rachillae $5-16 \mathrm{~cm}$ long, c. $0.7 \mathrm{~mm}$ thick, cream at flowering darkening to red-brown, closely and deeply striate, densely granular-papillose; larger axes similar, with deep grooves in addition to fine striations. Rachis bracts cylindric-conic broadening toward apex, to c. $4 \mathrm{~cm}$ diameter, loose and warped, thick-textured and stiffly coriaceous, rich chestnut-brown but rapidly greying on exposure, finely but rather obscurely striate; patchily clothed with floccose-tomentose orange-brown scales as on leaf undersides, these dense and continuous near apices; bract apices apparently initially ovate-cuspidate but breaking down at an early stage of development into a number of irregular, fibre-fringed teeth, resulting in a \pm truncate rather than 2-lobed bract. Flower-clusters 1-4 mm apart, 1-3-flowered; cluster axis $0.5-1.5 \mathrm{~mm}$ long, irregularly cylindrical, moderately slender. Cluster-bract ovate-triangular, c. $0.5 \mathrm{~mm}$ long, membranous, whitish, laciniate at apex but laciniae rarely surviving beyond early flowering stage. Bracteoles 1-3(-5?), similar to cluster-bract but smaller.

Flowers c. $1.8 \mathrm{~mm}$ long, broadly funnel-shaped. Anthopodium c. $0.5 \mathrm{~mm}$ long, moderately slender, obscurely trigonous and recessed at base. Sepals membranous, thickening toward median line and base, concave in lower half, $1.3 \mathrm{~mm}$ long, connate for $1 / 3$ their length, narrowly triangular, acute to slightly cuspidate. Petals moderately concave, thick and leathery, $2.0 \mathrm{~mm}$ long, broadly triangular-ovate, acute and strongly hooded at apex; auriculate at base with rather broadly rounded auricles, inner faces with 3 shallow cavities. Stamens c. $4 / 5$ as long as petals, connate for c. $2 / 5$ their length; filaments thick, broadly ovate-orbicular narrowing rather abruptly into subulate apex; anthers $0.45 \mathrm{~mm}$ long. Carpels almost equalling stamens; ovaries ovoid, very fat, strongly gibbous abaxially, narrowing rather gradually into styles c. $0.3 \mathrm{~mm}$ long.

Fruit spherical, c. $15 \mathrm{~mm}$ diameter, without obvious protrusions at stalk or stigma positions. Epicarp black, bluish-pruinose, dull and slightly dimpled, moderately thick but easily damaged. Mesocarp c. $1.2 \mathrm{~mm}$ thick, rather dry, reddish. Endocarp c. $0.1 \mathrm{~mm}$ thick, flexible but weak and membranous, pale red-brown. Seed subspherical, c. $13 \mathrm{~mm}$ long, $12 \mathrm{~mm}$ diameter, surface smooth, dull red-brown. Intrusion penetrating laterally from slightly below median position for c. $3 / 5$ seed diameter, in 1.s. narrowly anvil-shaped and occupying $1 / 2$ seed length, in t.s. shallowly 2-lobed at apex and occupying c. $2 / 5$ seed diameter. Embryo lateral (2.30? to 3 o'clock relative to stalk). (Fig. 4a, 12, 13a)

Distribution: restricted entirely to the summit and slopes of the Blackdown Tableland, which lies at the northern extremity of the Expedition Range in the lower Dawson River catchment, central eastern Queensland, latitude c. $23^{\circ} 45^{\prime} \mathrm{S}$, about $180 \mathrm{~km}$ from the coast near Rockhampton. 
Ecology: occurs in great abundance mainly along sandstone cliff-lines, on rocky footslopes below cliffs, in shallow rocky gullies on the plateau, and in deep sandstone gorges below major waterfalls around edge of the plateau. Most occurrences are at altitudes between 300 and $600 \mathrm{~m}$, the climate there being somewhat cooler and moister than that of the surrounding semi-arid lowlands. Grows in moderately tall eucalypt forest, dominated principally by a stringybark, Eucalyptus sphaerocarpa.

Conservation status: Briggs and Leigh (1996) assign the conservation code 2RC- to 'Livistona sp.1 Blackdown Tableland'. However, the major part of its population appears to be within the Blackdown Tableland National Park, so a coding of 2RCa is recommended.

Specimens examined: Queensland: Leichhardt: Slopes below N escarpment of Blackdown Tableland, Blaxell 921 E Johnson, 28 Nov 1972 (NSW); Blackdown Tableland, just below escarpment at NE end (road pass), Rodd 3063-3065 \& Jacobs, 11 May 1976 (NSW, BRI, K, BH); Blackdown Tableland, c. $35 \mathrm{~km}$ SE of Blackwater (campsite at old stockyard on Mimosa Creek), c. $8.5 \mathrm{~km}$ NNE of campsite (c. $0.8 \mathrm{~km}$ below the entrance gates) on the north facing scarps, Henderson 1180, Durrington \& Sharpe, 14 Sep 1971 (BRI, NSW).

\section{Notes}

1. The epithet fulva, Latin for 'tawny', draws attention to the striking golden-brown indumentum of the leaf undersides, a unique feature among Australian members of the genus, which otherwise have virtually glabrous leaves except for the ribs. The colour is hardly evident on older leaves, but on newly unfurled leaves, especially on semi-juvenile plants, it is immediately noticeable.

2. This species is sharply distinct from all other Australian species and shows no obvious relationships. Apart from the leaf indumentum, other striking characters are the presence of a slight abaxial hastula (which may be correlated with the weakly costapalmate lamina), the very shallow bifurcation of the segments (a neotenic character?) and the several-toothed apices of the rachis bracts.

3. The existence of this palm seems to have been quite unrecorded until the 1960s. It was observed but not collected by Mr C.H. Gittins, who in 1961 made some of the earliest botanical collections on the Blackdown Tableland, and in 1968 by L.A.S. Johnson and L.J. Pryor who were searching for a new eucalypt discovered by Gittins, and who thought it might be L. australis. I first saw it in August 1970 when driving up the forestry road, still under construction, through the northern escarpment; I made a leaf collection and believed at the time that it might be a new species. The first good collections (flowering) were made by Henderson et al., collecting for the Queensland Herbarium in 1971, and I collected good fruiting material in 1976.

4. The distribution of L. fulva is sharply delimited by the sandstone escarpment of the Blackdown Tableland; it is most abundant on the summit and around the base of the uppermost line of cliffs on the north and east sides of the plateau; it appears to reach its lowest altitude in the gorge of Mimosa Creek below the very high waterfall; it is not evident along the western escarpment, or on the highest parts of the plateau to the south of Mimosa Creek. It is reasonable to infer that the factors limiting its spread are rainfall and humidity, with temperature possibly also playing a part. Blackdown Tableland is an island of high rainfall and cool temperatures in a hot, semi-arid region with a long and severe dry season. The horizontally bedded sandstones have doubtless also assisted its survival, the seepage at cliff-bases providing a permanent source of soil moisture. The evident adaptation of this species to a mesic but relatively cool environment is uncommon among the Australian Livistona species, though L. australis appears to have similar requirements. 


\section{L. muelleri Bailey}

Bailey (1902: 1683); Domin (1915: 501); Beccari (1921: 19; 1931: 94, t. 7ii); Burret (1941: 326); Moore (1963: 150; 1973: 60); Covacevich \& Covacevich (1978: 92); Tucker (1980); Johnson (1980: 13); Jones (1984: 138)

Type: Queensland: Cairns, E. Cowley Oct 1900; holo BRI n.v.; iso FI n.v., photo NSW.

L. humilis R. Br. 'var.' [nov.] F.M. Bailey, Queensland Agric. J. 2: 130 (1898) [same specimen cited as type of L. muelleri].

L. humilis R. Br. var. sclerophylla Becc., Webbia 5(1): 76 (1921); Ann. Roy. Bot. Gard. (Calcutta) 13: 99, t. 7iii (1931).

Type: Queensland: Bloomfield River, Miss E. Bauer no. 3; lectotype (here designated) FI n.v., photo NSW; isolecto 'Miss Ellie Bauer, 12/[18]85' FI n.v., photo NSW. Of the two sheets of this collection, the one bearing a leaf (as well as a fruiting branch and fruits in a packet) is selected as lectotype.

?L. humilis R. Br. var. novoguineensis Becc., Webbia 5(1): 76 (1921).

Type citation: ‘Nuova Guinea olandese meridionale sul fiume Maroke (Jaheri nell’Erb. di Buitenzorg).'

Type: not seen.

L. brassii Burret, Notizbl. Bot. Gart. Berlin 12: 309 (1935).

Type citation: 'Brit. Neuguinea: Dagwa, Oriomo River, Western Division'

Type: Papua New Guinea: Western Division: Dagwa, Oriomo River, L.J. Brass 5950, Feb-Mar 1934; iso BRI.

L. crustacea Burret, J. Arnold Arbor. 20: 189 (1939).

Type citation: 'Papua: See Daviumbo, mittlerer Fly River'

Type: Papua New Guinea: Lake Daviumbu, Middle Fly River, L.J. Brass 7668, Sep 1936; holo A, iso BRI.

Trunk solitary, to c. $10 \mathrm{~m}$ tall, $15-20 \mathrm{~cm}$ diameter at $1 \mathrm{~m}$ above ground, often broadening gently but shortly at base into a cone up to $30 \mathrm{~cm}$ diameter on a pedestal of roots of still larger diameter (almost hemispherical on some old plants). Surface closely ringed with sheath scars; vertical fissures prominent, some long and deep, others short and very shallow; basal $2 \mathrm{~m}$ or so clothed in persistent, semi-appressed petiole-stubs often more than $10 \mathrm{~cm}$ long (if not burnt).

Crown \pm globose, somewhat truncated at base, consisting of c. 25-35 stiffly radiating leaves, most spreading at slightly above or slightly below horizontal. Ligules moderately prominent, straw-coloured to pale brown, outer surface sparsely to densely dotted with chestnut-brown (greying with age) \pm circular, thick, corky scales in pits, their surfaces flush with ligule surface.

Petiole 70-100 cm long, 14-19 mm wide; concave-convex to flattened-triangular in t.s. Margins bearing minute dark red-brown linear calli; toward base bearing somewhat sparse shiny blackish, antrorse, patent or retrorse, pungent prickles to c. $4 \mathrm{~mm}$ long; much shorter or sometimes absent on apical half. Surfaces green, undulately striate, the upper with numerous linear pits to $7 \mathrm{~mm}$ long containing conspicuous rows of thick, corky, antrorsely overlapping, persistent red-brown scales (soon fading to grey), their surfaces flush but papillose, appearing shaggy, their margins irregularly erose-fimbriate; lower similar but scale-bearing pits shorter, more numerous, tending to be aggregated into patches, the scales remaining red-brown longer. Hastula base truncate to rounded or shallowly 3 -lobed or rarely emarginate; rim at $10-60^{\circ}$ to costa, 
8-20 mm wide, sometimes rolled into a half-cylinder, entire to shortly cuspidate or 2-lobed or very irregular, the necrotic margin narrow to very broad and irregularly disintegrating.

Lamina 70-80(-90) cm long, $0.20(-0.25) \mathrm{mm}$ thick, weakly costapalmate, \pm circular with narrow sinus at base, chartaceous, brittle and readily splitting, to coriaceous and moderately tough; flat or slightly contorted with 1 gentle adaxial fold either side of costa and lower edges involute with only the lowest 1-2 segments either side resupinate. Segments 28-30 either side of costa; largest segments 25-32 mm wide, widest at base, free for $50-65 \%$ of their length, bifurcated for $5-14 \%$ of free length, the lobes parallel, shortly acute or (occasionally) abruptly curved outward, or more commonly tapering evenly to a fine bristle-like point. Intersegmental appendages delicate, brittle, threadlike, to $7 \mathrm{~mm}$ long, mostly absent from fully expanded leaves. Ribs: abaxial ribs in t.s. oblong, rounded to bluntly square-edged, $0.6-0.7 \mathrm{~mm}$ thick, 0.9-1.1 mm deep; adaxial ribs oblong, bluntly to quite sharply square-edged, $0.5-0.7 \mathrm{~mm}$ thick, 0.8-1.0 mm deep. Venation: major longitudinal veins 8-9 either side of midrib, prominent above, slightly less prominent beneath; transverse veins moderately prominent to somewhat obscure above, more prominent beneath, mostly angled, often quite steeply, frequently arcuate or sigmoid, frequently continuous across 2-3 longitudinal veins. Surfaces shiny olive green to somewhat grey-green above, below dull bluish-green with densely crowded stomates and slightly to moderately glaucous with thin, delicate waxy bloom, glabrous except for scurfy scales along angles of ribs toward base.

Inflorescences mostly slightly shorter than leaves, sometimes much shorter, fairly stiff and strongly ascending, somewhat pyramidal in form with stiffly spreading branches. Partial inflorescences 5-10, reducing markedly in size toward inflorescence apex, the lowest mostly exceeding $1 / 2$ of total inflorescence length; each branched to 3 , rarely 4 further orders; rachillae 1.5-13 cm long, 0.5-1.2 mm diameter (but only seen post-anthesis, probably enlarged), these and other axes pinkish-brown to dark red-brown, the surfaces wrinkled-striate and minutely granular-papillose giving a slight 'frosted' appearance. Rachis bracts smoothly flattened-cylindrical, to c. $25 \mathrm{~mm}$ diameter, tightly sheathing to somewhat undulately distorted or torn, dark red-brown, greying with age where exposed to sun; surfaces closely striate with raised veins, sparsely to densely flecked with pale straw-coloured to silvery appressed scales; bract apices narrowly ovate-triangular, mostly \pm cuspidate with necrotic tip, often with dense fringe of whitish scales along part of margin. Flower-clusters 1-3 mm apart, 1-3-flowered; cluster axis present only as a slight steplike protrusion on rachilla, to $0.5 \mathrm{~mm}$ long at anthesis, enlarging in fruit to up to c. $1.2 \mathrm{~mm}$ long and c. $1.4 \mathrm{~mm}$ diameter. Cluster-bract strongly reflexed, triangular, acute, c. $0.3 \mathrm{~mm}$ long. Bracteoles hardly detectable.

Flowers c. $1.6 \mathrm{~mm}$ long, campanulate. Anthopodium c. $0.2 \mathrm{~mm}$ long, somewhat trigonous at base, deeply recessed at point of attachment to cluster axis. Sepals moderately fleshy but membranous near apex, appressed to petals, slightly concave, 0.8-1.0 mm long, connate for c. $1 / 3$ their length, broadly triangular, shortly cuspidate at apex. Petals incurved, $1.3-1.6 \mathrm{~mm}$ long, connate for c. ${ }^{1 / 7}$ their length, ovate-triangular, subacute, slightly thickened at apex, auriculate at base with \pm rounded auricles overlapping those of adjacent petals, inner faces with 2 deep, narrow cavities close to margins. Stamens slightly shorter than petals, connate for c. $1 / 3$ their length, the filaments broadly triangular, strongly shouldered just above base, narrowing rather abruptly into a slender tapering apex; anthers $0.38 \mathrm{~mm}$ long. Carpels from c. $3 / 4$ as long as to almost equal to stamens; ovaries cylindric-ellipsoid, gibbous abaxially, narrowing somewhat abruptly into slender curved style $0.3-0.5 \mathrm{~mm}$ long.

Fruit broadly ellipsoid, 10.5-12 mm long, 8.5-10 mm diameter; apex rounded, base rounded or broadly conical often with small nipple at stalk position. Epicarp dark red-brown to black, often pruinose, moderately thick but not tough. Mesocarp c. $1.0 \mathrm{~mm}$ 
thick, oily and yellowish when fresh, red-brown and granular dried. Endocarp c. $0.15 \mathrm{~mm}$ thick, smooth, cartilaginous but easily broken. Seed subspherical, 8-9 mm long, 7.5-8.5 mm diameter, slightly flattened ventrally, dull red-brown, smooth. Intrusion narrow, \pm cylindrical, penetrating from a lateral position for up to $2 / 3$ seed diameter, in $1 . s$. slightly swollen or irregularly lobed at apex, occupying from less than $1 / 2$ to $5 / 8$ of seed length, in t.s. usually with 2 erect to diverging apical lobes, occupying c. $1 / 2$ or less of seed width. Embryo lateral, at or somewhat below mid-point of seed ( 3 to 4 o'clock relative to stalk). (Fig. 1d, 2c, 4b, 13b, 15a)

Distribution: far northern Queensland, from Cape York south to about $17^{\circ} 45^{\prime}$ (S of Innisfail) on east coast, and south on the west coast of Cape York Peninsula at least to mouth of Edward River, possibly to Mitchell River. South of Cooktown it is confined strictly to coastal lowlands, but further north in the Peninsula it extends further inland. Also in Papua New Guinea, in lowlands around Gulf of Papua, Fly River region and probably also in adjacent parts of Irian Jaya.

Ecology: in North Queensland this species occurs in greatest numbers in poor woodland communities dominated by Melaleuca viridiflora and Eucalyptus alba on flat, seasonally swampy interfluves on sandy soils of low fertility frequently with a clay hardpan below the surface. It may also occur on the outer margins of gallery rainforest or, in northern Cape York Peninsula, in or adjacent to patches of vine forest. In Papua New Guinea it is recorded as 'solitary or in small groves on rainforested shores of lake and extending less commonly to the dry savannahs' and 'common palm of savannah forest on open grass slopes'.

Conservation status: not considered at risk.

Specimens examined: Queensland: Cook: Jardine River, N bank, near crossing of Peninsula Development Road, Hind 576, Oct 1974 (NSW); Musgrave Station, Hind 749, Sep 1979 (NSW); 14 km WNW of Cooktown on McIvor River Road, Hind 748, Sep 1975 (NSW); N side of Endeavour River near Jones Lagoon, 11 km WNW of Cooktown, Rodd 3159 \& Jacobs, 21 May 1976 (NSW, BRI, K, BH); Bloomfield River road c. 3-5 km N of Ayton, Rodd 3170, 22 May 1976 (NSW, BRI, K, BH); Craiglea, Bruce Highway near Port Douglas turn-off, Hind 226, Aug 1972 (NSW); Trinity Beach area, north of Cairns, Maconochie 1717, 22 May 1972 (DNA).

Papua New Guinea: See type citations of synonyms L. brassii and L. crustacea. In field notes on his New Guinea collections L.J. Brass describes it as 'Solitary or in small groves on rainforested shores of lake [L. Daviumbu, middle Fly R.], and extending less commonly to the dry savannahs' and 'Common palm of savannah forest on open grass slopes, alt. $45 \mathrm{~m}$.' [Dagwa, Oriomo R.]

\section{Notes}

1. A very distinctive species, not likely to be confused with any other. In the field it is unmistakable among Australian species for its very stiff, short-petioled, almost flat leaves, radiating horizontally. Herbarium specimens are most remarkable for their petiole indumentum, consisting of rows of very corky brownish scales sunken in long pits, their surfaces flush with the petiole surface.

2. Chapman (1991), in his listing of L. muelleri Bailey, comments 'nom. illeg. non Wendl.', referring to a prior name supposedly published by Wendland in Kerchove (1878). But on examining this publication we find that it is merely a name mentioned in passing, one item in a brief summary of all the palms known from Australia, thus: 'A la première région [i.e. "la région tropicale"] apartiennent les Calamus caryotoides et radicalis, ... Livistona humilis, Ramsayi, Leichardti et Mülleri, Licuala Mülleri et Cocos nucifera.' It is clear that L. muelleri H. Wendl. is a nomen nudum and of no standing.

3. Burret (1941), in discussing the likelihood of his L. brassii proving conspecific with L. muelleri, drew attention to the petiole scales. Oddly, though, he drew no comparison 
between either of these species and his later-described L. crustacea, the description of which follows closely that of L. brassii.

4. L. muelleri appears to have some affinities with L. humilis and L. eastonii, sharing with them shallowly bifurcated leaf-segments and distinctive rows of red-brown basal-cell masses of fallen scales on the petioles. The corky, thick scales of L. muelleri, though, set it apart sharply from these species. In another direction, it may have an affinity with L. benthamii, sharing with it a number of inflorescence, flower and fruit characters.

5. One collection (Rodd 3170) is remarkable for the inflorescence having empty tubular bracts additional to the prophylls sheathing the bases of its lower partial inflorescences, a departure from the virtually standard inflorescence pattern in Australian Livistona. However, this does not appear in other collections and further field observation is required to ascertain whether it is characteristic of a population.

6. Field observations indicate that in a population of this species a large proportion of plants do not produce fruit, evidenced by their old inflorescences lacking thickened fruiting cluster axes. Good collections of flowering specimens may reveal whether or not there is any sexual dimorphism evident in the flowers. It is possible even that the bract character described above may be correlated with sexual state.

7. The type material of Beccari's L. humilis var. sclerophylla in FI consists of two sheets, the first consisting of a whole leaf, partial inflorescence and a packet of seeds; the second of only partial inflorescence and a packet of seeds. Their labels are essentially the same, except that the second bears the date ' $12 / 85^{\prime}$ while the first has no date. As indicated above, the first is here chosen as lectotype. Beccari presumably failed to equate this collection with Bailey's L. muelleri (of which he had adequate material, also with mature fruit) because he was unaware that the leaf was juvenile and hence much smaller than the L. muelleri leaves he had available. The Bauer specimen's fruits are also at one extreme of the length: diameter ratio found in L. muelleri, whereas the type of the species has fruits tending towards the other extreme.

8. Hind 748 bears the note 'fruits blackish, flesh yellow smelling strongly of banana and very oily'. The mature fruits of this collection were the chief source for the fruit and seed description here.

\section{L. humilis R. Br.}

Brown (1810: 268); Martius (1838: 239); Wendland \& Drude (1875: 231); Beccari (1921: 19; 1931: 95); White (1988: 23, 25).

Type: Gulf of Carpentaria, Island 's' [= Morgans Island, Blue Mud Bay], R. Brown s.n., 20.I.1803 (Bennett No. 5796); holo BM, photo NSW, iso K, FI n.v., photo NSW.

Saribus humilis (R. Br.) O. Kuntze, Rev. Gen. Pl. 2: 736 (1891).

L. leichhardtii F. Muell., Fragm. 8: 221 (1874).

Type citation: 'In Arnhemia et regionibus vicinis, ubi jam Leichhardtio notata.'

Lectotype (here chosen): Arnhem's Land, McAdam's Ranges, F. Mueller s.n., 1855; holo MEL.

Trunk solitary, to $7 \mathrm{~m}$ tall, 5-8 $\mathrm{cm}$ diameter, broadening slightly right at ground. Surface patterned with petiole scars, sheath scars not prominent; vertical fissures sparse, irregular, narrow; most of trunk bearing appressed petiole-stubs to c. $3 \mathrm{~cm}$ long. Crown globose, very open, consisting of c. 8-15 stiffly ascending to spreading and slightly arching leaves. Ligules not very prominent, disintegrating at an early stage into a network of fibres with only a narrow entire rim, the outer surface pale brown with raised veining, clothed with appressed fimbriate white scales. 
Petiole (30-)40-60(-70) cm long, (7-)8-14 mm wide; flattened-triangular to transversely obtrullate in t.s. with very rounded keel. Margins armed with prickles interspersed with irregular small blunt teeth and minute linear brown calli; prickles up to $3 \mathrm{~mm}$ long, narrow, very pungent, mostly dark-tipped, all antrorsely falcate except for a few retrorsely sigmoid ones near base, sometimes few or absent on upper third of petiole but mostly present on whole length. Surfaces green to brownish or somewhat reddish, obscurely striate, densely and conspicuously speckled with small dark red-brown linear markings representing sunken basal-masses of early-deciduous appressed white fimbriate scales, fairly uniformly distributed over both surfaces. Hastula base truncate, shortly and bluntly apiculate; rim at $10-40^{\circ}$ to costa, $3-8 \mathrm{~mm}$ broad, convex, semicircular to irregularly lobed or split, the necrotic margin very variable, broad or narrow, continuous or interrupted.

Lamina (28-)35-55 cm long, 0.2-0.3 mm thick, moderately costapalmate, \pm circular, truncate at base or with broad to fairly narrow sinus; chartaceous-coriaceous, somewhat brittle and springy, only slightly contorted with one adaxial undulation either side of the often strongly deflexed costa, base on either side involute but segments not resupinate. Segments 15-22 either side of costa; largest segments 12-32 mm wide, free for $60-87 \%$ of the lamina length, bifurcated for $49-89 \%$ of free length, the lobes parallel to slightly divergent, tapering at first convexly and then concavely to a fine but rarely threadlike point. Intersegmental appendages very fine, threadlike, to $3 \mathrm{~cm}$ long on younger leaves, soon broken off. Ribs: abaxial ribs in t.s. oblong-elliptic, bluntly to sharply square-edged, narrowest at junction with lamina, up to $0.8 \mathrm{~mm}$ thick, $1.0 \mathrm{~mm}$ deep; adaxial ribs similar but slightly smaller. Venation: major longitudinal veins 4-8 either side of midrib, very prominent above, slightly less prominent beneath; transverse veins somewhat obscure above, prominent beneath, mostly near-orthogonal and discontinuous, on some specimens tending to more steeply-angled and continuous across several longitudinal veins. Surfaces glossy green or slightly brownish green, glabrous except on ribs, or lamina as well as ribs bearing numerous red-brown fine spots, as on petiole but not so elongated, pustular rather than sunken, mainly on veins but a few between veins; denser scurfy white hairs present on rib bases close to hastula, but disappearing at an early stage.

Inflorescences very markedly dimorphic; those on fruit-bearing plants twice as long as leaves (to c. $2 \mathrm{~m}$ ), straight and strongly ascending, completely unbranched except for the apical $25-35 \mathrm{~cm}$ which is strongly deflexed and represents a single (terminal) partial inflorescence; those on non-fruiting plants up to about $50 \%$ longer than leaves, ascending but usually arching in upper part, with 4-7 subequal partial inflorescences, these branched to 3 further orders; rachillae $2.5-12 \mathrm{~cm}$ long, $0.4-0.7 \mathrm{~mm}$ thick, these and other axes obscurely striate and sparsely to densely bristly-pubescent with white hairs c. $0.1 \mathrm{~mm}$ long or shorter. Rachis bract of fruit-bearing plants complemented basally by a succession of 5-8 empty peduncular bracts, these (and rachis bract) flattened-bicarinate, $10-15 \mathrm{~mm}$ wide, tightly sheathing, straight and regular, rigidly coriaceous, green (or reddish brown toward apex), finely striate with alternating coarser and finer wrinkles, densely to very sparsely but evenly scurfy-pubescent with small, appressed, longitudinally oriented, transparent laciniate scales; rachis bracts of non-fruiting plants similar but slightly broader and looser; bract apices narrowly triangular-ovate, long-acuminate, necrotic, somewhat warped, looser on non-fruiting plants. Flower-clusters 1-3 mm apart, 2-4-flowered; cluster axis (on fruit-bearing plants) a mere raised bump at rachilla node, or (on non-fruiting plants) knob-like, to c. $0.7 \mathrm{~mm}$ long. Cluster-bract ovate-triangular to $0.5 \mathrm{~mm}$ long, membranous except at base, often discernible only as a narrow rim by anthesis. Bracteoles usually 1 per flower, shorter and blunter than cluster-bract, or (on non-fruiting plants) mostly not discernible.

Flowers c. $1.8 \mathrm{~mm}$ long, \pm globose to cylindric-globose. Anthopodium extremely short, concave at base with a downward-projecting bump below each sepal. Sepals strongly 
concave and appressed to petals, membranous near apex, thickening toward base, c. $1.3 \mathrm{~mm}$ long, connate for c. $1 / 4$ their length, orbicular-ovate, apex very shortly and \pm bluntly cuspidate. Petals moderately concave, thick and fleshy, c. $1.8 \mathrm{~mm}$ long, connate for c. $1 / 4$ their length, very broadly triangular-ovate, bluntly acute and shallowly cymbiform at apex, broad-based and auriculate above base, with minute triangular auricles; inner faces with well marked but not deep cavities. Stamens at least $4 / 5$ as along as petals, connate for c. $1 / 2$ their length; filaments very thick, broadening apically with well marked high shoulders, abruptly and rather shortly cuspidate; filaments in non-fruiting plants shorter and broader with more rounded shoulders; anthers on fruit-bearing plants $0.35 \mathrm{~mm}$ long, the loculi apparently lacking pollen; on non-fruiting plants c. $0.4 \mathrm{~mm}$ long, the loculi containing pollen. Carpels slightly shorter than stamens; ovaries broadly ovoid, abaxially strongly gibbous, tapering gradually into slender styles c. $0.4 \mathrm{~mm}$ long; ovaries in non-fruiting plants globose, very plump, with shorter styles and containing apparently well-formed ovules.

Fruit ellipsoid-pyriform to obovoid, sometimes flattened or slightly concave adaxially and gibbous abaxially, 11-19 mm long, 8-10 mm diameter. Epicarp smooth, dull pinkish-purple ripening to shiny black. Mesocarp c. $0.6 \mathrm{~mm}$ thick, soft and pulpy. Endocarp to $0.2 \mathrm{~mm}$ thick, quite hard, the outer surface with a number of longitudinal ridges. Seed ellipsoid to subglobose, flattened adaxially, 6-7 mm wide. Intrusion small, penetrating from a lateral position for only $\frac{1}{2}$ width of endosperm, in l.s. with short lobes pointing toward base and apex and occupying only c. $1 / 2$ of seed length, in t.s. usually narrow with 2 slightly diverging lobes. Embryo lateral but distinctly below mid-point of seed. (Fig. 4c, 13c, 14)

Distribution: Northern Territory, the 'Top End', virtually ubiquitous in suitable habitats north of about the Fitzmaurice River in the west and the Roper River in the east, though apparently absent from the Katherine-Mataranka area.

Ecology: appears to be restricted to flat or gently undulating interfluvial areas on deep sandy soils, usually with pisolithic ironstone gravel, or on bauxite, in open eucalypt forest nearly always dominated by Eucalyptus tetrodonta, usually with E. miniata also present.

Conservation status: not considered at risk.

Selected specimens examined: Northern Territory: Oenpelli, Specht 1221, 19 Oct 1948 (AD); c. 80 km E of Oenpelli, Maconochie 1598, 28 June 1972 (DNA, AD, PERTH); Darwin \& Gulf: Arnhem's Land, McAdam's Ranges, Mueller s.n., 1855 (MEL); Macmillan Road, 8 miles [13 km] SE Darwin, Chippendale NT4391, 24 May 1958 (DNA, NSW); Cannon Hill Airstrip (near Darwin), Martensz $\mathcal{E}$ Schodde AE617, AE618, 30 Jan 1973 (DNA, CANB); Stuart Highway c. $35 \mathrm{~km} \mathrm{~N}$ of Batchelor, Eichler 17887, 17888, 2 July 1964 (AD); Stuart Highway, c. 160 km SSE of Darwin, Jackson 1050, 4 June 1967 (AD); Melville Island, Spencer s.n., July-Aug 1911 (NSW, MEL); Strauss Airstrip, 28 miles [45 km] S Darwin, Must 957, 8 Mar 1972 (DNA, CANB); Daly Range, 14 km S of Manton R on Stuart Highway, Rodd 2910, 2911, 30 Oct 1974 (NSW, DNA, K, BH); 16 miles [26 km] NE of Tipperary Homestead, Lazarides 6687, 27 July 1961 (CANB, NSW); c. 4 miles [6.4 km] W of Pine Creek Township, Lazarides \& Adams 227, 15 Mar 1965 (CANB); Macdonnell Airstrip, 67 miles [108 km] N of Katherine, Maconochie 1300, 1971 (DNA, CANB, K); About 2 miles [3.2 km] NW Caiman Ck, Byrnes 1014 \& Maconochie, 27 Sep 1968 (DNA, NSW); Munmarlary Stn., Latz 957, 10 May 1973 (DNA, CANB); 10 miles [16 km] W Jim-Jim, Byrnes 1725, 21 Sep 1969 (DNA, CANB); Obiri Rock, Maloney 2, 18 July 1975 (NSW); 36.3 miles [58 km] N Oenpelli, Chippendale NT8108, 15 July 1961 (DNA, NSW); c. 20 km SE of Maningrida, Rodd 2923, 2924, 31 Oct 1974 (NSW, DNA, K, BH); 36 miles [58 km] N Wilton R.-Bulman Crossing, Maconochie 1457, 15 June 1972 (DNA, CANB); Elcho Island, Maconochie 2179, 12 July 1975 (DNA, NSW, CANB, K); Wessell Islands, Latz 3470, 10 Oct 1972 (DNA, CANB); c. 1.5 km W B.H.P. Camp [near Caledon Bay], Maconochie 1560, 22 June 1972 (DNA, CANB, NSW, K); 4 miles E of Lake Evella turnoff, Maconochie 1513, 18 June 1972 (DNA, PERTH); Gove Peninsula, halfway between Gove Airport and Nhulunbuy Township, Rodd 2926, 2927, 2928, 2 Nov 1974 (NSW, DNA, CANB, K). 


\section{Notes}

1. A distinctive species, easily recognised by its small stature, the smallest of any Australian species. Herbarium material might possibly be confused with L. inermis, from which it differs in its non-pruinose leaves, profuse brown linear markings on both sides of petiole and frequently on leaf-blade, inflorescences greatly exceeding leaves, and bristly-pubescent rachillae. Its unbranched 'female' inflorescences are a striking feature, not found in any other species.

2. Brown's brief diagnosis of this species is barely adequate to allow its recognition, but as well as the description there is Bauer's beautiful plate, correctly captioned with the correct name (presumably with guidance from Brown) and published eventually in Martius's (1838) Historia Naturalis Palmarum. The photograph of Brown's type specimen published at folio size in Beccari's 1931 monograph also allows no doubt as to the application of the name. Beccari interprets L. humilis correctly but seems to find some confusion in the Bauer illustrations (of L. humilis and L. inermis) in Martius. To me these illustrations both appear correctly named and quite unambiguous.

3. Mueller makes no mention in his protologue of L. leichhardtii of the specimen that he himself collected on the McAdam Range (near the Fitzmaurice River), here accepted as type of that name. It is a very adequate specimen of L. humilis, which can be seen in MEL, labelled L. leichhardtii in his own hand. Mueller later (1878) remarked that his L. leichhardtii probably included Brown's L. inermis and L. humilis, implying that Brown's descriptions were too vague for definite application of the names.

4. Although in many Australian Livistona species there is a strong suspicion of functional dioecism or androdioecism, accompanied by slight dimorphism in inflorescence structure, it is only in L. humilis that this is expressed strongly and unequivocally. The briefest inspection of any stand reveals two extraordinarily different inflorescence types, segregated on different plants, and (to the best of my knowledge) fruit set occurs on only one of these. This is the inflorescence type with no lateral partial inflorescences, only a solitary terminal one on a very long peduncle sheathed in a succession of peduncular bracts. The non-fruiting plants have inflorescences which, though small and slender, conform to the 'standard' Livistona type with a succession of short, subequal partial inflorescences. The flowers in these two types look rather different but a systematic survey of their structure reveals only slight differences, principally empty anther locules on the fruiting plants; the carpels and ovules in both types appear normal, though ovule structure has not been examined at high magnification. Clearly there is scope for a fuller investigation of the reproductive behaviour of this species, indeed of all Livistona species.

5. White (1988) illustrates an instance of inferred hybridism between L. humilis and L. inermis, though makes no mention of this in his text. The two are sympatric over most of the range of L. inermis, though generally ecologically segregated. I have found a few vegetative specimens difficult to assign to one species or the other, and so believe such hybrids may well exist. Again, further investigation is needed.

6. See also discussion under L. benthamii, L. inermis and L. eastonii.

\section{L. eastonii C.A. Gardner}

Gardner (1923: 36); Beard (1976: 183); Hnatiuk (1977); Jones (1984: 133); Wilson (1992: 1249. fig. 353A).

Lectotype (here designated, as no specimen was actually cited by Gardner): Western Australia: Lower King Edward River, C.A. Gardner 1544, 22 Aug 1921 (PERTH [specimen with a whole inflorescence and a juvenile leaf, bearing a 'holotype' sticker]); isolecto PERTH [specimen with a whole leaf blade (but no petiole) and small piece of 
inflorescence, with determination slip in Gardner's (?) hand and a red 'isotype' sticker], CANB, K, BH, B.

Trunk solitary, to 11 (?20) $\mathrm{m}$ tall, c. $12 \mathrm{~cm}$ diameter, broadening abruptly close to ground into a broad conical or bulbous base up to $30 \mathrm{~cm}$ diameter. Surface toward base without noticeable sheath scars; vertical fissures deep, prominent, especially toward base; petioles or sometimes whole dead leaves persistent up to a height of 2.5-3 m, but mostly seen burnt off leaving regular spiral rows of appressed stubs $2-10 \mathrm{~cm}$ long; leaves shed higher up leaving prominent, closely crowded scars.

Crown somewhat elongated, open, consisting of c. 10-15(-30?) rather stiff leaves, all but the youngest few drooping due to bending of petioles. Ligules not very prominent, soon tearing into a net of narrow criss-crossing ribbons, pale red-brown ageing to silvery grey, with dense, appressed, transparent, very short scales.

Petiole (55-) 65-80(-90) cm long, 14-20 mm wide; flattened-triangular to broadly obtrullate or concave-convex in t.s. Margins armed with mixed antrorse, patent and retrorse, narrow, mostly blunt prickles to c. $4 \mathrm{~mm}$ long; shorter, blunter and sparser near petiole apex; minute elongated brown calli also present. Surfaces pale yellowish green, irregularly but sometimes markedly striate, with \pm profuse, evenly distributed linear red-brown to purple-black rows of basal-masses to $2 \mathrm{~mm}$ long in shallow pits, bearing early-deciduous, often tightly twisted white or pale brown scales. Hastula variable; base narrowly to broadly triangular or shortly and asymmetrically 3-lobed; rim at $20-50^{\circ}$ to costa, fairly smooth and flat, to c. $10 \mathrm{~mm}$ wide with broad but often irregular necrotic margin, often disintegrating in patches.

Lamina $60-90 \mathrm{~cm}$ long, $0.25-0.30 \mathrm{~mm}$ thick, strongly costapalmate, truncate at base with all segments forward-pointing, coriaceous, tough and moderately flexible; only moderately contorted with 1 adaxial undulation either side of the slightly to strongly deflexed costa, sometimes shortly involute at base with lowest 1-2 segments either side resupinate. Segments 20-27 either side of costa; largest segments $22-31 \mathrm{~mm}$ wide, free for $50-90 \%$ of their length, bifurcated for $49-63 \%$ of free length, the lobes parallel or slightly converging or diverging, not or barely drooping, evenly tapering to fine, acute, somewhat rigid apices mostly shortened by early necrosis. Intersegmental appendages fine, brittle, threadlike, early-deciduous, occasionally up to $4.5 \mathrm{~cm}$ long, mostly absent on mature leaves Ribs: abaxial ribs in t.s. oblong to trapeziform (narrowing to lamina), square-edged, to $0.9 \mathrm{~mm}$ thick, $1.3 \mathrm{~mm}$ deep; adaxial ribs rectangular to somewhat tapering or oval, not generally square-edged, to $0.8 \mathrm{~mm}$ thick, $1.2 \mathrm{~mm}$ deep. Venation: major longitudinal veins 5-9 either side of abaxial rib, evident but not always prominent above, \pm obscure beneath; transverse veins obscure to evident above, evident to moderately prominent beneath, mostly angled, many continuous across several longitudinal veins and frequently arcuate. Surfaces pale greyish-green, somewhat yellowish above, moderately pruinose on both sides but with a more prominent and softer waxy bloom on underside; glabrous except for ribs which bear rows of orange-brown calli mainly along angles.

Inflorescences approximately equalling leaves, steeply ascending but with pendulous branches. Partial inflorescences 5-6, each branched to 4 further orders, the rachillae $0.2-8 \mathrm{~cm}$ long, $0.3-0.5 \mathrm{~mm}$ thick; all axes glabrous, wrinkled-striate, pinkish-brown in bud stage soon changing to pallid whitish. Rachis bracts cylindric to moderately flattened, bicarinate, to c. $20 \mathrm{~mm}$ diameter, smooth and tightly sheathing to somewhat looser and warped, stiff and parchment-like, initially pinkish straw-coloured but soon ageing to deep red-brown, closely striate, bearing closely appressed, fimbriate, translucent white or pale brown scales giving a densely flecked appearance; bract apices long-triangular, acute to slightly acuminate, frequently with scaly-tomentose margins. Flower-clusters $0.5-3.5 \mathrm{~mm}$ apart, 1-3(-4)-flowered; cluster axis \pm knob-like or forked, $0.1-0.7 \mathrm{~mm}$ long. Cluster-bract broadly triangular, c. $0.4 \mathrm{~mm}$ long, membranous, its apex initially delicately acuminate-fimbriate. Bracteoles 1-3, resembling cluster-bract but often shorter. 
Flowers 1.6-1.9 mm long, campanulate to rotate. Anthopodium $0.2 \mathrm{~mm}$ long, not distinct from base of calyx, bulging downward into 3 fleshy knobs below sepals, base recessed at point of attachment to cluster axis. Sepals loosely appressed to petals, moderately concave, somewhat fleshy right to apex, 0.6-1.0 mm long, connate for $1 / 3$ their length, broadly ovate-triangular, acute. Petals rather thin and tough, 1.6-1.9 mm long, connate for $1 / 6-1 / 5$ their length, narrowly oblong-ovate to triangular-ovate, rounded toward the broadly acute apex, minutely auriculate at base with auricles usually rounded, retrorse, overlapping; inner faces lacking obvious cavities though with shallow longitudinal ridges. Stamens $4 / 5-9 / 10$ as long as petals, connate for $1 / 3-2 / 5$ their length; filaments moderately thin, broadly triangular-ovate, tapering smoothly to a slender, elongated point, not obviously shouldered; anthers $0.40-0.42 \mathrm{~mm}$ long, containing pollen except in 1 specimen (Rodd 2887) from fruit-bearing plant, in which cells are consistently narrow and empty. Carpels from $2 / 3$ as long to virtually as long as stamens; ovary broadly ellipsoid to cylindric-ellipsoid, strongly gibbous abaxially and sometimes apically also, rather abruptly narrowed into slender, \pm straight style $0.25-0.5 \mathrm{~mm}$ long.

Fruit obovoid-pyriform to ellipsoid, 13.5-16 $\mathrm{mm}$ long, 8-9 $\mathrm{mm}$ diameter, straight to slightly curved but not flattened adaxially, narrowly conical to almost rounded at base, rounded to bluntly apiculate at apex. Epicarp purple-black, smooth and glossy when fresh, rather coarsely wrinkled when dry, sometimes pruinose, moderately thick and tough. Mesocarp 1.0-1.3 mm thick, soft and pulpy. Endocarp $0.15 \mathrm{~mm}$ thick, quite smooth, adhering closely to seed. Seed obovoid to ellipsoid, 10-13 mm long, $7 \mathrm{~mm}$ diameter, barely flattened adaxially. Intrusion penetrating from lateral position for $1 / 2-2 / 3$ seed width, in l.s. irregularly lobed with short lobes directed toward seed apex and base, occupying $1 / 2-2 / 3$ seed length, in t.s. narrow and with 2 erect lobes. Embryo lateral, almost exactly midway between seed base and apex. (Fig. 1c, 4d, 16, 17a-b)

Distribution: Western Australia: northern Kimberley Region, apparently confined to the Mitchell Plateau south of Admiralty Gulf and the region to the east and south-east as far as the lower King Edward River and the middle-upper Drysdale River.

Ecology: restricted to more or less level plateau areas on deeply weathered soils with abundant lateritic gravel; on such sites the most robust plants occur in gully heads or moist depressions, but the species appears to be absent from immediately adjacent sites on sandstone such as gorges and cliff-lines where no laterite is developed. Gardner describes it as occurring also on 'basalt plains and hills'. On its preferred sites L. eastonii forms huge populations, with all age-classes well represented, and is most frequently co-dominant with Eucalyptus miniata and E. tetrodonta, or sometimes with the latter only, usually forming a community with few other conspicuous trees or shrubs.

Conservation status: not considered at risk.

Specimens examined: Western Australia: Gardner: 15 miles [24 km] S of Admiralty Gulf, Kimberley, Gardner 972, 8 July 1921 (PERTH); 75 miles [121 km] NNW of Gibb River Station, Speck 4949, 7 Sep 1954 (CANB); c. 15 miles [24 km] N of Amax Bauxite Camp, Mitchell Plateau, Maconochie 1281, 1 May 1971 (DNA, CANB, K, PERTH); 15 miles [24 km] S of mouth of Mitchell River, Schulze s.n., 20 Jan 1973 (PERTH); Mitchell Plateau, N Kimberley, Beard 6992, 7 June 1974 (PERTH, NSW); Amax Bauxite Camp, Mitchell Plateau, $20 \mathrm{~km} \mathrm{SSW}$ of head of Port Warrender, Rodd 2888, 26 Oct 1974 (NSW, PERTH, K, BH); Mitchell Plateau, $25 \mathrm{~km}$ SSW of head of Port Warrender, Rodd 2887, 26 Oct 1974 (NSW, PERTH, K, BH); woodland S of Airfield Swamp, Mitchell Plateau, West Kimberley, Hnatiuk MP36, 13 June 1976 (PERTH); N end of runway, Mitchell Plateau Airfield, Hnatiuk MP28, 13 June 1976 (PERTH); 2.9 km SE of Mitchell Plateau Mining Camp, George 14503, 23 Apr 1977 (PERTH, CANB, LE); 100 miles [c. 161 km] S of Kalumburu, Hutchinson 84, 19 July 1970 (PERTH); 25 miles [40 km] N of New Drysdale Station Homestead, Maconochie 1228, 28 May 1971 (DNA, PERTH, CANB, MEL, NSW); c. $12 \mathrm{~km} \mathrm{~N}$ of Drysdale River crossing on Kalumburu road, Symon 10254, 30 May 1975 (NSW); Doongan Station, Crossland Creek at Gibb River - Kalumburu road crossing, Telford 6096 \& Butler, 24 July 1977 (CBG, PERTH, NSW); 11 km N of Doongan H.S. 
turn-off from Gibb R-Kalumburu road, George 15220, 25 June 1978 (PERTH, CANB, NSW, AD, K); $8 \mathrm{~km}$ N of Doongan H.S. turn-off from Gibb R-Kalumburu road, George 15221, 25 June 1978 (PERTH, CANB, NSW, K).

\section{Notes}

1. A very distinctive species, instantly recognisable in the field though not always so clearly from herbarium specimens. Geographically it is very nicely delimited, showing overlap only with L. lorophylla, but they are not ecologically sympatric.

2. Gardner, whose botanical travels in the northern Kimberley in 1921 may still be unrivalled in their coverage of some regions, described L. eastonii in 1923 without Latin description and without designating a type but these were not mandatory under the ICBN at that time. Gardner named the species in honour of William R. Easton, surveyor, leader of the Kimberley Expedition of 1921.

3. Of the two collections in PERTH, the lectotype (Gardner 1544, Lower King Edward River) is more complete than the other (Gardner 972, 15 miles south of Admiralty Gulf) which consists only of pieces of petiole and of inflorescence in bud. Both localities fall within the geographical range he specifies, though the Admiralty Gulf one is admittedly more explicitly stated.

4. Taken literally, 'Lower King Edward River' would refer to the area around the present settlement of Kalumburu, but L. eastonii is not present there; more likely it means somewhere closer to the middle reaches of this river, paralleling the Lawley River, which ties in with present-day knowledge of this species' distribution.

5. Observations by L.A.S. Johnson (pers. comm.) were that travelling north in the Kimberleys, L. eastonii is first recorded close to 'Doongan' and thence sporadically toward the Mitchell River turn-off but cuts out before the turn-off; it is thereafter absent on the Kalumburu road and east of Kalumburu toward Forrest River Aboriginal Reserve; on the Mitchell River fork it appeared again close to the King Edward River crossing and was present most of the way from there to 'Mitchell River' Station. He noted its presence in a number of eucalypt associations additional to its usual occurrence in the E. tetrodonta-E. miniata association.

6. L. eastonii appears to be most closely related to L. humilis and L. muelleri. Morphological features shared by this trio include relatively shallow lobing of the leaves with stiff, non-attenuate apices to the secondary lobes; lamina with very few undulations; petiole with early-deciduous scales leaving profuse and conspicuous elongated, dark-coloured basal-cell masses giving a distinctive surface-texture; rachis bracts relatively narrow, smooth and tight with very regular, shortly cuspidate apices, thin and tough in texture with silvery flecking of closely appressed translucent scales; flowers and flower-clusters virtually sessile, the clusters not elongated; fruits elongated. Within this group L. eastonii is readily distinguished by its strongly pruinose leaves, their size intermediate between those of the other two, as is the trunk diameter. Geographically and ecologically these three species show a striking pattern: in the three major projecting land-masses of far northern Australia they extend south to roughly similar latitudes (c. $15^{\circ}$ in northern W.A., $14^{\circ}$ in N.T., $17^{\circ}$ in Qld), and occur on similar topography and soils, i.e. flattish interfluvial areas on deep sandy or lateritic soils, in this respect contrasting sharply with geographically sympatric species in all three regions. They show a strong association with Eucalyptus tetrodonta, though in Cape York Peninsula L. muelleri extends further southeast than this eucalypt. Such habitats are arguably subject to a greater fire frequency than any other Livistona habitats and the degree of fire-adaptation of these three species appears to reflect this: all seem to have a very prolonged geophytic juvenile phase, frequently seen sprouting new leaves after fires; but all Australian Livistonas appear fire-adapted to a considerable degree. 


\section{L. inermis R. Br.}

Brown (1810: 268); Martius (1838: 239, t. 145, 146 iv-vi); Beccari (1921: 20; 1931: 102, t. 7iv); Blake (1954: 128); White (1988); Birch \& Dowe (1989: 11)

Type: Gulf of Carpentaria, Island h [= North Island, Sir Edward Pellew Group], Brown [Bennett No. 5795], 16(?) Dec 1802; holo BM (mounted on 5 sheets), photos NSW; iso FI, photo NSW.

Saribus inermis (R. Br.) O. Kuntze, Rev. Gen. Pl. 2: 736 (1891).

Trunk solitary, to $10 \mathrm{~m}$ tall, 6-10 $\mathrm{cm}$ diameter, broadening near base into a short cone up to c. $15 \mathrm{~cm}$ diameter; or sometimes branching from base to produce clump of up to c. 6 aerial stems of mixed height together with many unelongated sucker shoots with juvenile leaves, springing from root mass up to c. $70 \mathrm{~cm}$ wide at ground. Surface of basal 1-2 $\mathrm{m}$ of trunk bearing closely appressed petiole stubs to $5 \mathrm{~cm}$ long; leaves shed cleanly higher up leaving regular pattern of petiole scars but only rather obscure rings. Crown globose, very sparse, consisting of c. 30 arching to drooping leaves with somewhat drooping segments. Ligules straw-coloured, clothed with very closely appressed transparent scales.

Petiole 65-95 cm long, 6.5-10.5 mm wide, concavo-convex to transversely obtrullate in t.s., with slightly rounded keel. Margins obscurely crenate with minute pale brown calli or variably armed with mixed antrorse and retrorse, narrow, falcate or sigmoid, pungent, mostly dark purplish prickles to $5 \mathrm{~mm}$ long, if present on apical half then much shorter, patent, blunt, not dark-coloured. Surfaces dull pinkish-purple especially toward base, variably pruinose (sometimes thickly), somewhat striate, upper glabrous, lower sparsely to densely clothed with closely appressed to loose, scurfy, laciniate white to pale orange-brown scales. Hastula irregular, variable; base shortly 3-lobed to truncate-apiculate to shallowly V-shaped to semicircular; rim at $20-90^{\circ}$ to costa, 3-7 mm broad, sometimes contorted, necrotic margin narrow and entire to broad and interrupted.

Lamina 33-65 $\mathrm{cm}$ long, $0.25-0.40 \mathrm{~mm}$ thick, weakly to moderately costapalmate, approximately semicircular to almost circular, truncate to broadly notched at base, coriaceous, flexible; slightly to strongly contorted with 1 adaxial undulation either side of the barely to strongly deflexed costa and base on either side involute with lowermost 2-6 segments resupinate. Segments 12-24 either side of costa; largest segments 11-21 mm wide near point of bifurcation, free for (80-)91-97\% of their length, bifurcated for (70)73-84\% of free length, the lobes parallel or slightly diverging, usually broadening above point of bifurcation, 6-13 mm wide at widest point, their apices tapering evenly to a fine point. Intersegmental appendages to c. $5 \mathrm{~cm}$ long, delicate and hairlike, soon broken off. Ribs: abaxial ribs in t.s. \pm square but not very sharp-edged, to $0.7 \mathrm{~mm}$ thick, $0.9 \mathrm{~mm}$ deep; adaxial ribs similar, to $0.6 \mathrm{~mm}$ thick, $0.8 \mathrm{~mm}$ deep, or in some specimens hardly protruding above lamina. Venation: major longitudinal veins 8-10 either side of abaxial rib, prominent on both surfaces; transverse veins obscure above, prominent below, from orthogonal to steeply angled, frequently continuous across several longitudinal veins. Surfaces concolorous, green to strongly greyish-pruinose, glabrous except for tufts of dense, scurfy, whitish to straw-coloured scales on bases of ribs.

Inflorescences shorter than to barely equalling petioles, but broader than long, the peduncle to c. $30 \mathrm{~cm}$ long and the rachis nodes only $4-10 \mathrm{~cm}$ long. Partial inflorescences usually 3 , the lowermost \pm equalling the remainder of the inflorescence, branching to a further 3 orders; rachillae 1-7 cm long, $0.3 \mathrm{~mm}$ thick, these and other axes wrinkled-striate, bright creamy yellow at anthesis, later darkening to reddish-brown grading to whitish on rachillae. Rachis bracts commonly reduced to only one tubular one (sometimes none) subtending lowermost partial inflorescence, somewhat flattened-bicarinate, c. 12-15 mm diameter, rather loose but generally 
smooth and entire, toughly papery, finely and evenly striate, pale straw-coloured outside, red-brown inside, with inconspicuous mats of strongly contorted transparent hairs, densest toward apex; higher rachis bracts much smaller, linear-lanceolate; bract apices somewhat elongated, triangular-ovate, not cuspidate, entire. Flower-clusters $1-4 \mathrm{~mm}$ apart, 1-3-flowered; cluster axis slender, $0.2-2 \mathrm{~mm}$ long, elongating in fruit to up to $3 \mathrm{~mm}$ long. Cluster-bract c. $0.5 \mathrm{~mm}$ long, narrowly triangular, acute to acuminate or sometimes laciniate at apex, whitish-hyaline, very delicate, apical $1 / 2-3 / 4$ usually shrivelled away by anthesis. Bracteoles 2-3, resembling cluster-bract or shorter and rounded.

Flowers broadly funnel shaped to rotate, $1.8-2.3 \mathrm{~mm}$ long. Anthopodium slender, $0.2-0.6 \mathrm{~mm}$ long. Sepals concave, very loosely cupping petals, whitish-scarious except at base, $0.7-1.4 \mathrm{~mm}$ long, connate for $1 / 5-1 / 3$ their length, narrowly triangular to somewhat ovate, acute to slightly acuminate. Petals rotately spreading or forming a funnel, leathery in texture, thin to moderately thick, $1.5-1.9 \mathrm{~mm}$ long, broadly ovate-oblong to triangular-ovate with apiculate, thickened, slightly hooded apex, auriculate at base with prominent, rounded, downward-pointing auricles (or auricles occasionally lacking); inner faces with 3-4 parallel raised nerves close to centre. Stamens $2 / 3-4 / 5$ as long as petals, connate for up to c. $1 / 3$ their length; filaments broadly triangular-ovate, rather abruptly tapering into elongated acuminate apex, obscurely shouldered low on each margin; anthers $0.3-0.4 \mathrm{~mm}$ long. Carpels c. $1 / 2$ as long as petals; ovaries very broad, cylindric-globose, their summits very gibbous abaxially, rather gradually tapering into tapering styles under $0.2 \mathrm{~mm}$ long.

Fruit obovoid-pyriform or ellipsoid, usually slightly flattened or even concave adaxially, 10-12 mm long, 6-7 mm diameter, base tapering or rounded or with abrupt short conical projection, apex rounded sometimes with stigma persisting as short prickle. Epicarp dull purplish, slightly pruinose, ripening to glossy black (finely wrinkled with reticulum of sharp ridges when dry). Mesocarp c. $1 \mathrm{~mm}$ thick, soft and pulpy, purple, with numerous deep red tannin bodies when dry. Endocarp adhering tightly to both mesocarp and seed. Seed 8-9 mm long, 5-5.5 mm wide. Intrusion small, penetrating from a lateral position for little more than $1 / 2$ width of endosperm, irregularly lobed mainly toward seed base and apex. Embryo lateral, midway between seed base and apex or slightly above. (Fig. 4i, 20c-d, 21).

Distribution: Northern Territory, escarpments of far north and north-east, extending south-west to around Katherine and south-east to just across the border into far northwest Queensland; also islands of the western half of Gulf of Carpentaria.

Conservation status: not considered at risk.

Selected specimens examined: Northern Territory: Darwin \& Gulf: Arnhem Highway, 2 km W of West Alligator River, Benson 952, 11 June 1974 (NSW); 21 miles [34 km] NW of Katherine, Lazarides 6627, Sep 1961 (CANB); 91 km from Pine Creek towards UDP Falls, Gittins 2590, July 1973 (NSW, DNA); Katherine Gorge, 15 miles [24 km] NE of Katherine Lazarides 6990, 15 Sep 1964 (CANB, NSW); Katherine Gorge, c. 1/2 km SE of National Park headquarters, Rodd 2931, 2932, 3 Nov 1974 (NSW, DNA, K, BH); 8 km NW of El Sharana, Benson 994, 18 Dec 1974 (NSW); Vicinity of El Sharana Mining Camp, Martensz E Schodde AE384, 17 Jan 1973 (CANB); Pine Creek-Oenpelli Road, vicinity of Mudginberry Station, Symon 10347 (NSW); Munmalary Station, (Kay L.S.), Latz 3728, 10 May 1973 (DNA, CANB); Kakadu National Park, 6 km SW of Mt Brockman, Telford 8064 E Wrigley, 23 Apr 1980 (CBG, NSW); Kakadu National Park, 2.5 km NW of Koongarra Saddle, Telford $8114 \mathcal{E}$ Wrigley, 24 Apr 1980 (CBG, NSW); c. 90 km S of Maningrida, Maconochie 1581, 25 June 1972 (DNA, CANB, K); Gulf of Carpentaria, Maria Island, Dunlop 2836, 14 July 1972 (DNA, DWL, BRI, AD, CANB, NSW); South West Island, McKey 101, 24 May 1970 (DNA, K, NSW); Centre Island, Sir Edward Pellew Group, Craven 3841, 11 Feb 1976 (CANB); Rice 2037, 10 Sep 1975 (NSW, BRI). Barkly Tableland: Echo Gorge, Wollogorang Station, Thomson 802, 27 Nov 1984 (DNA, NSW). 


\section{Notes}

1. Most previous attempts to apply this name, which together with L. humilis forms part of Brown's protologue of Livistona, seem to have been surrounded by uncertainty and confusion. Martius (1838), who apparently saw no material, suffered no such confusion, for he had available (and published magnificent reproductions of) Bauer's very accurate and detailed drawings which can quite satisfactorily be tied to Brown's type collection.

2. Mueller (1865, 1874, 1878) virtually ignored Brown's L. humilis and L. inermis, apparently including them in his vaguely defined L. leichhardtii, together with the entity now distinguished as L. benthamii.

3. Wendland and Drude (1875) appear to have based their fairly lengthy description of L. inermis largely on Queensland east-coast specimens, citing " Rockingham"! (Folia et semina matura lect. initio Septembris 1865)' and “"Moore's Creek Range near Rockhampton"! (leg. Thozet)'. These (seen in MEL) are respectively L. drudei and L. decipiens according to the present treatment. In deference to Brown's concept of the species Wendland and Drude added 'Regiones circa sinum Carpentaria ex narrationibus plurum investigatorum (Burke, Wills, Stuart etc.)'.

4. Bentham (1878) confessed to knowledge of this species only from the accounts of Brown and Martius, and concluded: 'It may prove to be a variety only of L. humilis.'

5. Beccari (1931) gave an accurate, amplified description of the type material, at least as to flowers and fruits. However, the leaf he described seems more like that of L. humilis than of L. inermis as described here or as figured by Bauer (in Martius). Beccari, in discussion, infers from this discrepancy that Bauer's habit and leaf illustrations represent a different species from the flowers and fruits, possibly his (Beccari's) L. rigida (type also from Gulf of Carpentaria). Recent collections and field observations fully support the accuracy of Bauer's illustrations, so Beccari's hypothesis has turned out to be false.

6. Blake (1954), in notes on northern Australian plants, was the first to apply Brown's name to any recently found palm in the Northern Territory, though only tentatively. He noted, under L. 'inerme', 'A small-leaved slender palm with smooth petioles probably belonging to this species was observed in 1946 about SE of the junction of the McKinlay and Mary Rivers, but as the plants were sterile no specimens were collected.'

7. Specht (1958) in an account of the Arnhem Land flora made no mention of L. inermis, though the Oenpelli district, where it is known to occur, was one of his main centres of collecting. He presumably did not distinguish it from L. humilis.

8. As now interpreted, this species exhibits considerable variation, and further observation and collecting are needed. Basally branching trunks seem to occur only in some populations, judging from specimen notes and accompanying photographs, but do not appear to correlate with characters of leaf, inflorescence or flower. Leaf size is very variable as is degree of dissection: most commonly encountered are leaves dissected to within 1-3 cm of the hastula, but the other extreme is represented by Benson 952, with leaves dissected only to within 7-8 cm of the hastula, with very broad segments; this collection also shows a variant flower type, with shorter, thicker, more triangular-acute petals than in others examined, though features such as calyx and inflorescence agree with L. inermis. Alternatively it may be a hybrid with L. humilis (see note under that species).

9. It is possible that some form of sexual dimorphism is expressed in the floral variation, though there does not appear to be dimorphism in overall inflorescence structure. 
10. Thomson 802, from close to the extreme south-east of the known range of the species, is also somewhat atypical in the large size of its leaves and breadth of segments; it is possible, but unlikely, that further collections and observations in this area will reveal it as belonging to a distinct entity.

11. Birch and Dowe (1989) report L. inermis from Queensland, on Westmoreland Station about $20 \mathrm{~km}$ from the Northern Territory border and $65 \mathrm{~km}$ inland from the gulf. They describe its habitat as chiefly bases of cliffs of sandstone conglomerate, which is consistent with its occurrences in the Northern Territory.

\section{L. lorophylla Becc.}

Beccari (1921: 18; 1931: 87, t.6, f.5 ); Wilson (1992: 1249, fig. 353B); as 'loriphylla'.

Type citation: ‘Nord Ovest Australia nel Cambridge Gulf, a circa $120^{\circ} 20^{\prime}$ long. E. Gr.e $15^{\circ}$ L. S. (Johnson)'

Type: Western Australia: Cambridge Gulf, Johnson s.n.; holo FI, photo NSW (2 sheets); iso 'Johnston 1885' MEL, NSW (fragment only). The geographical coordinates cited in the protologue are not on any specimen; they represent a spot a long way out to sea north-west of Cambridge Gulf.

Trunk solitary, to $5 \mathrm{~m}$ tall, 8-10 $\mathrm{cm}$ diameter, broadening slightly at the very base into a short cone. Surface closely ringed with leaf-scars; vertical fissures rather sparse but quite long and crooked; basal 2-3 m of trunk bearing crowded, appressed petiole stubs 1-4 cm long, leaves and sheaths shed cleanly higher up. Crown globose, very open, consisting of 30-40 mostly arching to drooping leaves. Ligules with ragged edges, outer surface dull straw-brown with mosaic of darker brown corky scales.

Petiole 90-100 cm long, 11-12 mm wide, flattened-triangular in t.s. with rounded keel. Margins with regularly-spaced linear brown calli, toward base armed with a few irregularly scattered, slender, patent or retrorsely hooked dark brown prickles up to $3 \mathrm{~mm}$ long. Surfaces red-brown, darker at base, the upper smooth to obscurely striate, largely glabrous, the lower \pm densely scurfy-tomentose, less so toward apex, with appressed tomentum of flaky white to pale brown scales. Hastula rather irregular; base shortly and broadly 3-lobed, \pm truncate except for central apiculum; rim at c. $30^{\circ}$ to costa, convex, 4-9 mm broad, necrotic margin broad and irregular.

Lamina 65-100 cm long, 0.30-0.35 mm thick, strongly costapalmate, \pm semicircular in outline, with broad basal sinus and costal region often strikingly pinnate with conspicuous gaps between segment bases, coriaceous, flexible; slightly contorted with 1 adaxial undulation either side of the barely deflexed costa and lower edges involute with lowest 4-6 segments either side resupinate. Segments c. 17-24 either side of costa; largest segments $14-20 \mathrm{~mm}$ wide narrowing to $8-9 \mathrm{~mm}$ at base, free for $95-98 \%$ of their length, bifurcated for $55-78 \%$ of free length, the lobes diverging at $20-30^{\circ}$, apices finely attenuate, threadlike. Intersegmental appendages threadlike, to c. $2.5 \mathrm{~mm}$ long. Ribs: abaxial ribs in t.s. bluntly square-edged, up to $0.9 \mathrm{~mm}$ thick, $0.9 \mathrm{~mm}$ deep; adaxial ribs hardly projecting from lamina. Venation: major longitudinal veins $7-8$ either side of abaxial rib, prominent on both surfaces; transverse veins prominent, mostly discontinuous and near-orthogonal with respect to longitudinal veins. Surfaces olive-green, concolorous, somewhat glossy, glabrous except for dense white to brownish scurfy tomentum on bases of ribs on both surfaces.

Inflorescences shorter than or just equalling petioles, ascending and arching. Partial inflorescences 4-6, subequal, branching to 3 further orders; rachillae $0.2-5 \mathrm{~cm}$ long, $0.3-0.5 \mathrm{~mm}$ thick; all axes glabrous, brown to reddish turning white post-anthesis with spongy amorphous surface layer of cells. Rachis bracts slightly flattened, bicarinate, c. $14 \mathrm{~mm}$ diameter, toughly papery, finely but deeply rugulose-striate, pale reddish-brown, densely but not conspicuously scurfy-tomentose with matted, crinkled, transparent hairs, densest near apices; bract apices triangular to rounded, 
obtuse to acute, not cuspidate, often densely fringed with hair-like scales. Flowerclusters 1-2 mm apart, 1-4-flowered; cluster axis knoblike, 0.2-0.5 mm long. Cluster-bract c. $0.5 \mathrm{~mm}$ long, initially broad and pale brown at base narrowing to a transparent, serrate to laciniate apical portion, mostly shrivelled by anthesis. Bracteoles 2-3, lunate to triangular-acuminate, irregularly laciniate, often resembling cluster-bract.

Flowers 1.2-2.0 mm long, broadly funnel-shaped to cup-shaped. Anthopodium very short, hardly distinguishable from calyx. Sepals membranous, loosely cupping petals, c. $0.7 \mathrm{~mm}$ long, connate for c. $2 / 5$ their length, triangular-ovate, acute to slightly cuspidate. Petals thin-textured, c. $1.2 \mathrm{~mm}$ long, barely connate, broadly ovate with slightly thickened acute or very shortly cuspidate apex, strongly auriculate at base, with no obvious cavities on inner faces. Stamens c. $4 / 5$ as long as petals, connate for almost $1 / 2$ their length; filaments broadly triangular-ovate, mostly slightly shouldered low on each side, thence tapering \pm smoothly to a finely cuspidate apex; anthers $0.2 \mathrm{~mm}$ long. Carpels little more than $1 / 2$ as long as petals; ovaries obovoid-cylindric, summit strongly gibbous abaxially, abruptly narrowed into slender straight styles c. $0.2 \mathrm{~mm}$ long.

Fruit (only seen immature) obovoid-pyriform, dorsally gibbous, c. $9 \mathrm{~mm}$ long, $6 \mathrm{~mm}$ diameter. Mesocarp c. $0.6 \mathrm{~mm}$ thick. Seed not seen mature. Intrusion lateral, elongated along long axis of fruit, irregularly lobed especially toward fruit base and apex. Embryo lateral, closer to apex than to stalk. (Fig. 4h, 19, 20a-b, 21)

Distribution: scattered sporadically through the northern Kimberley region of north Western Australia, from a little north of Derby eastward to the west shore of Cambridge Gulf, and with an outlier in the Northern Territory; nowhere more than about $100 \mathrm{~km}$ from the coast.

Ecology: usually associated with outcrops of sandstone or siliceous metasediments, including low 'breakaways' in the broad river valleys, cliff ledges of major gorges, and rims of plateaus. Associated vegetation is commonly dominated by the prickly grasses of genera Triodia and Plectrachne, usually with sparse stunted trees including Terminalia spp., Ficus spp., Owenia vernicosa, Persoonia falcata, and some of the smaller Eucalyptus and Corymbia species.

Conservation status: not considered at risk.

Specimens examined: Western Australia:Fitzgerald: West Kimberley (Brockmans Expedition), House s.n., 1901 (PERTH); Stewart River, c. $68 \mathrm{~km}$ NNE of Derby, 14 km from Kimbolton HS. towards Gibb River road, Telford 6404 \& Butler, 2 Aug 1977 (CBG, NSW, PERTH). Gardner: Uwins Is, Brunswick Bay, Wilson 11450, 8 July 1973 (PERTH); W5 Marigui Promontory, Prince Regent River Reserve, Kenneally 2162, 27 Aug 1974 (PERTH, NSW); North Kimberley, Speck 4916, Sep 1954 (PERTH); Lower King Edward River, Gardner 1544, 22 Aug 1921 (PERTH); Sir Graham Moore Is, Wilson 11222, 30 June 1973 (PERTH); c. 3 km ESE of Kalumburu Mission, Rodd 2871, 2872, 25 Oct 1974 (NSW, PERTH, K, BH); 3 miles [5 km] NNW of Kalumburu Mission, Speck 4916, 4 Sep 1954 (CANB); Kalumburu Mission, Brigden DNA6885, Aug 1973 (CANB); Kalumburu, Crawford 58, 6 Jan 1974 (PERTH); Douglas \& Mees s.n., 3 July 1960 (PERTH); Lullfitz s.n., 18 Jan 1975 (PERTH); Drysdale River National Park, George 13758, 12 Aug 1975 (PERTH, NSW); Site B3, Cracticus Falls, Kenneally 4153, 9 Aug 1975 (PERTH, NSW); Site C5, Fern Gully, Drysdale River National Park, Kenneally 4557, 20 Aug 1975 (PERTH); Site C3, Planigale Creek, Drysdale River National Park, Kenneally 4447, 19 Aug 1975 (PERTH).

Northern Territory: Victoria River: Victoria River area, 151'ㄴ, 129 $35^{\prime} \mathrm{E}$, Dunlop 8203 \& Leach, 9 Mar 1989 (NSW).

\section{Notes}

1. The epithet was published by Beccari as 'loriphylla' but under article 60.8 of the ICBN is to be corrected. Loron, a thong or strap, was adopted into Greek from Latin lorum. Liddell \& Scott (1864) list three combinations in the form loro- with other Greek words 
(see also such botanical names as Loropetalum). The form lori- would, of course, be correct in combination with a Latin word.

2. This species characteristically occurs on sandstone cliff ledges and around 'breakaways' over a large area of the northern Kimberleys. On heavier basaltic and bauxitic soils in the central part of its range it is replaced by the locally very abundant L. eastonii, a quite unrelated species; in the increasingly arid range country to the south it is replaced by L. kimberleyana, which appears to be closely related.

3. The Northern Territory palm sometimes determined as 'L. lorophylla' is here treated as L. inermis R.Br. It is possible that a broad concept of the latter species might take in the north Kimberley plants, in which case Beccari's name would be reduced to synonymy, but differences in growth-habit, stature, colouring and inflorescence structure seem sufficiently consistent to warrant their separation.

4. George 13758 and Kenneally 4153 (from Drysdale River National Park) both exhibit a remarkable androecium: the antesepalous stamens are nearly all replaced by staminodes varying from quite petal-like to much narrower, incurved at tip and of irregular shape, but usually 2 of the larger staminodes have adnate to their inner face (as do the normal petals) an additional complete stamen of normal appearance. This bizarre flower structure was not found in other collections from areas nearer the coast. However, the sample available is very small; it remains to be seen whether these represent a localised aberrant population, or alternatively represent the normal condition for one of the sexual states in the species as a whole. However, dissection of flowers of the isotype fragment in NSW, and buds of two other pre-anthesis collections revealed a normal arrangement of stamens. In other respects this species appears to show relatively little variation, considering its apparently rather fragmented distribution.

\section{L. kimberleyana Rodd, sp. nov.}

Palma solitaria magnitudine mediocris, trunco ad $15 \mathrm{~m}$ alto, c. $15 \mathrm{~cm}$ diametro; coma globosa foliis cinereo-viridibus, debilibus, versus apices cernuis; petioli $150-180 \mathrm{~cm}$ longi, 14-17 mm lati proxime laminam. Laminae costapalmatae, c. $90 \mathrm{~cm}$ longae, dissectae fere ad hastulam; segmentis c. $25 \mathrm{~mm}$ latis, profunde bifurcatis apicibus subtiliter attenuatis. Inflorescentiae quam petiolis breviores vel aequilongae, c. 7 ramis lateralibus, illis denuo 3-plo ramosis rhachillis $0.4-6 \mathrm{~cm}$ longis, $0.8 \mathrm{~mm}$ diametris. Flores 1-2(-3?)-fasciculatae. Fructus obovoidei, parvi.

Type: Western Australia: SW base of Mt King, Durack Range, $17^{\circ} 20^{\prime} \mathrm{S}, 1^{\circ} 7^{\circ} 23^{\prime} \mathrm{E}$, A.N. Rodd 2866, 24 Oct 1974; holo NSW; iso PERTH, CANB, K.

[Livistona sp. A, Wilson (1992: 1250); Livistona sp. 'Kimberlies' (Jones 1984)]

Trunk solitary, to c. $15 \mathrm{~m}$ tall, $13-15 \mathrm{~cm}$ diameter at $1 \mathrm{~m}$ above ground, generally broadening gradually at base into a narrow cone up to $25 \mathrm{~cm}$ diameter. Surface closely ringed with prominent sheath-scars; vertical fissures rather sparse, short, fairly straight; basal 1-1.5 m bearing closely appressed petiole-stubs to c. $5 \mathrm{~cm}$ long, leaves and sheaths shed cleanly higher up.

Crown globose, open, consisting of about 40 strongly arching to pendulous leaves, usually with a skirt of dead leaves hanging beneath. Ligules not observed.

Petiole c. 150-180 cm long, 14-17 mm wide; flattened-triangular in t.s. with rounded keel. Margins on upper half of petiole with closely spaced minute dark calli, toward base with retrorse or less commonly antrorse prickles, often dark-tipped, hooked and pungent, up to $5 \mathrm{~mm}$ long. Surfaces pale dull pinkish, strongly pruinose, obscurely to prominently striate, the lower with irregularly scattered bands of elongated shallow pits containing minute blackish dot-like or linear basal-masses obscured by appressed white scurfy scales. Hastula short, very irregular; rim appressed against costa, 5-9 mm 
wide, roughly semicircular, triangular or ovate, strongly cuspidate, asymmetric, with irregular patches of necrotic margin.

Lamina 70-100 cm long, $0.4 \mathrm{~mm}$ thick, strongly costapalmate, almost circular in outline with broad basal sinus, coriaceous, flexible; moderately contorted with 1 adaxial undulation either side of the slightly deflexed costa and involute at base with few segments on either side resupinate. Segments 20-22 either side of costa; largest segments $23-25(-33) \mathrm{mm}$ wide, free for $85-90 \%$ of their length, bifurcated for $59-76 \%$ of free length, the lobes flexuose, lying almost parallel, their apices finely attenuate but not thread-like except on lower segments. Intersegmental appendages inconspicuous, threadlike, c. $3 \mathrm{~cm}$ long, soon breaking off. Ribs: abaxial ribs in t.s. oblong, bluntly square-edged, to $1.0 \mathrm{~mm}$ thick, $1.5 \mathrm{~mm}$ deep; adaxial ribs much shallower. Venation: major longitudinal veins 7-8 either side of abaxial rib, prominent on both surfaces; transverse veins clearly visible on both surfaces, mostly discontinuous, most near-orthogonal with respect to longitudinal veins. Surfaces slightly discolorous, greyish-green, both surfaces quite glabrous, moderately pruinose but wax layer not easily damaged.

Inflorescences (seen only in immature fruit stage) as long as or slightly shorter than petioles, stiff and straight. Partial inflorescences c. 8, these branching to 3 further orders; rachillae $0.4-6 \mathrm{~cm}$ long, c. $0.8 \mathrm{~mm}$ thick; all axes pallid straw-coloured with a hard, waxy surface layer. Rachis bracts c. $2 \mathrm{~cm}$ diameter, slightly distorted, straw-coloured tinged pinkish, finely striate, glabrous except for patches of appressed, transparent, colourless contorted scales toward apex; bract apices ovate, obtuse to shortly cuspidate. Flower-clusters $1-3 \mathrm{~mm}$ apart, 1-2(-3?)-flowered; cluster axis $0.3-0.8 \mathrm{~mm}$ long. Cluster-bract c. $0.5 \mathrm{~mm}$ long, broadly triangular-cuspidate. Bracteoles 2-3, to $0.5 \mathrm{~mm}$ long, resembling cluster-bract.

Flowers: Anthopodium c. $0.3 \mathrm{~mm}$ long, c. $1.0 \mathrm{~mm}$ diameter, bulging downward at base, deeply recessed at junction with pedicel. Sepals fleshy-textured with rather narrow hyaline rim, c. $1.8 \mathrm{~mm}$ long, connate for c. $1 / 3$ length, broadly triangular, bluntly acute. Petals thick-textured, deep reddish-brown, to $1.5-3.0 \mathrm{~mm}$ long, triangular, hooded at the apex with somewhat inflexed small callous point, cavities on inner faces not very distinct. Stamens c. $4 / 5$ or more as long as petals, connate for up to half their length; filaments very broadly triangular, narrowing rather abruptly into shortly acuminate apices; anthers c. $0.45 \mathrm{~mm}$ long and almost as wide. Carpels (seen as squashed remains) equalling stamens, abruptly narrowing into slender oblique styles c. $0.3 \mathrm{~mm}$ long.

Fruit (only seen very immature) obovoid, c. 8 mm long, 6 mm diameter. (Fig. 4g, 17d)

Distribution: Western Australia — ranges of central Kimberley Region, mainly King Leopold and Durack Ranges, through both of which it appears to be widely distributed.

Ecology: occurs usually in rocky ravines and along cliff bases and on cliff ledges, mostly associated with siliceous sediments and metasediments. Associated trees include Corymbia aspera and Gardenia spp., while the ground layer is dominated by Triodia spp. and Plectrachne spp.

Conservation status: not considered at risk by Briggs and Leigh (1996), if not being listed can be interpreted thus. However, there is hardly evidence of the existence of large populations of this species, and there appear to be no national parks coinciding with its range (maybe Tunnel Creek N.P.?), so a listing of 3R may be more appropriate; further investigation is needed.

Specimens examined: Western Australia: Fitzgerald: c. 26 km NE of Inglis Gap, Symon 10154, 23 May 1975 (NSW); Mt Ord Gorge, King Leopold Ranges, 20 miles [32 km] SSW of Mt House Stn, Lazarides 6453, 29 July 1959 (CANB); Teroni Gorge, 12 miles [19 km] NNW of Elgie Cliffs Station, East Kimberleys, Lazarides 6395, 22 July 1959 (CANB); SW base of Mt King, Durack Range, Rodd 2867, 24 Oct 1974 (NSW, PERTH, CANB, K); Chamberlain River Gorge, 7 km E of El Questro Station 
homestead, Kenneally 10978, 30 June 1989 (PERTH, NSW); Mt Leake, Fitzgerald 1206, July 1905 (PERTH); Mt Broome, Fitzgerald 815, May 1905 (PERTH)

\section{Notes}

1. This was formerly confused with L. alfredii (e.g. Fitzgerald 1918; Gardner 1923 and see note under that species).

2. Fitzgerald (1918) reported 'L. alfredii' as occurring on 'Mts Herbert, Broome, Leake and Barnett; Isdell, Harris and Phillips Ranges; junction of Hann and Barnett Rivers (W.V.F.)' - some of which fill in the crescent formed by the King Leopold and Durack Ranges.

3. Gardner (1923) gives for 'L. alfredii' the distribution 'Synnot Creek near Charnley River, King Leopold Ranges near Prince Regent River, and sandstone ranges near the lower King Edward River and Napier Broom Bay. Among sandstone rocks in elevated situations, King Leopold Ranges and Sir Frederick Hills.' Some of these localities would extend its distribution a long way north, but it is more than likely that they represent occurrences of L. lorophylla, which Gardner apparently did not distinguish from his 'L. alfredii'. Neither Fitzgerald nor Gardner appear to have collected specimens to support their observations, which is perhaps understandable considering the conditions under which they travelled.

4. Its closest relationship appears to be with L. lorophylla Becc., from which it differs principally in its overall larger dimensions, its pruinose foliage and its much thicker, more rigid inflorescence rachillae. It is possible that toward the northern part of its range it may show some intergradation with that species, in that one or two specimens seen have not been unequivocally referable to one or the other. It is possible even that further study may show it to represent an arid race of L. lorophylla, but for the meantime it seems preferable to treat it as a distinct species.

5. The type locality in the Durack Range is also the type locality for L. mariae subsp. occidentalis, and indeed these two very different taxa grow together here in a rocky ravine, but showing different ecological preferences, with a grove of $L$. mariae confined to permanent soaks in the bed of the ravine, and scattered L. kimberleyana among rocky outcrops on the lower slopes - the populations nonetheless intermingling at the boundaries. At the time of my visit I observed (and photographed) some individuals that did not seem clearly referable to one or another of these taxa and suspected that they might be hybrids, but time did not permit collection of a specimen.

\section{L. victoriae Rodd, sp. nov.}

Palma solitaria magnitudine mediocris, trunco ad $12(-20) \mathrm{m}$ alto, c. $20 \mathrm{~cm}$ diametro. Coma foliis pruinosis rigide radiantis; petioli c. $1 \mathrm{~m}$ longi, $25 \mathrm{~mm}$ lati proxime laminam. Lamina valde costapalmata, c. $1 \mathrm{~m}$ longa. Inflorescentia 4-8 ramis lateralibus, illis denuo 4-plo ramosis, rhachillis $0.5-3.0 \mathrm{~cm}$ longis, gracillimis. Fructus subglobosi-ellipsoidei, in siccitate ad $11 \mathrm{~mm}$ longi, $10 \mathrm{~mm}$ diametro, sutura ventrali manifesta. Semina intrusione testa laterali, parvo, embryone fere basali.

Type: Northern Territory: c. $3 \mathrm{~km} \mathrm{~W}$ (by road) of Victoria River crossing, KatherineKununurra road, $15^{\circ} 35^{\prime} \mathrm{S}, 1^{\circ} 1^{\circ} 06^{\prime} \mathrm{E}$, alt. c. 80 m, A.N. Rodd 2934, 3 Nov 1974; holo NSW; iso DNA, K, PERTH.

[Livistona sp. 'Victoria River' (Jones 1984); 'Livistona sp. B' (Wilson 1992: 1250)]

Trunk solitary, to 12 (-20?) $\mathrm{m}$ high, c. $20 \mathrm{~cm}$ diameter at $1 \mathrm{~m}$ above ground, hardly reducing upward, broadening close to ground into a somewhat bulbous swelling to c. $30 \mathrm{~cm}$ diameter. Surface rather obscurely ringed with sheath scars, becoming smooth on lower trunk with age; vertical fissures not very conspicuous; petiole-stubs c. $4 \mathrm{~cm}$ 
long present on lowest 2-3 m of trunk, closely appressed with irregular, abraded or somewhat ragged ends.

Crown rather open, with pale blue-grey cast, globose or slightly elongated, consisting of 30-40 leaves with gently arching to drooping petioles, the leaf-blades continuing in the same plane with straight segment-lobes but conspicuously decurving costa. Ligules prominent, whitish or pale brown, contorted, subglabrous, strongly impressed between fibres, tearing early from petioles but leaving large, roughly triangular remnants attached to them.

Petiole 100-110 cm long, 22-28 mm wide, strongly flattened-triangular in t.s. with rounded keel, slightly concave above but often with slight median keel. Margins obscurely denticulate or toward base armed with irregularly scattered blunt, antrorse or patent prickles up to c. $2 \mathrm{~mm}$ long. Surfaces pale dull pinkish, strongly pruinose, obscurely and finely striate; lower surface, and to a lesser extent upper, bearing unevenly but densely scattered groups of slightly elongated shallow pits containing brown linear rows of minute basal-masses, appressed white fimbriate scales spreading from margins of pits, glabrescent with age. Hastula flat; base narrowly V-shaped to somewhat ovate-apiculate, often very asymmetric; rim at c. $20^{\circ}$ to costa, $3-7 \mathrm{~mm}$ wide, with mostly narrow necrotic margin.

Lamina 90-110 cm long, 0.35-0.40 mm thick, strongly costapalmate, with broad basal sinus, fairly stiff and harsh, tough and not readily split; strongly contorted with 1 adaxial undulation either side of the strongly deflexed costa, at base on either side shortly involute with lowermost 2-3 segments resupinate. Segments 20-28 either side of costa; largest segments $29-40 \mathrm{~mm}$ wide, free for $55-65 \%$ of their length, tapering slightly toward point of bifurcation, bifurcated for $55-70 \%$ of free length, the lobes evenly tapering but attenuated at apices into slender, necrotic threads, breaking off with age. Intersegmental appendages present, moderately persistent, straight, white, mostly c. $5 \mathrm{~cm}$ long. Ribs: abaxial ribs in t.s. oblong, somewhat bluntly square-edged, c. $2.5 \mathrm{~mm}$ deep, c. $1.0 \mathrm{~mm}$ wide; adaxial ribs very similar. Venation: major longitudinal veins 9-11 either side of abaxial rib, moderately prominent above, less prominent below; transverse veins moderately prominent on both surfaces, often steeply angled, often continuous across most of the width of the half-segment. Surfaces concolorous, strongly pruinose, glabrous except for ribs bearing scales and brown markings as on petiole.

Inflorescences variable in length, from slightly shorter than petioles to about petiole plus half lamina length. Partial inflorescences 5-9, subequal, the largest slightly over half total inflorescence length, each branched to 4 further orders; rachillae $0.4-3 \mathrm{~cm}$ long, 0.4-0.6 mm thick, cream when fresh, glabrous; larger axes striate, often very sinuous; all axes minutely papillose (appearing pallid with age). Rachis bracts usually loose and distorted, becoming split and raggedly fibrous with age, thick and harsh-textured, straw-coloured aging silver-grey though more reddish-brown toward apices, finely striate, unevenly but often densely woolly with closely appressed, matted, somewhat curly, narrow white scales; bract apices elongated, acute or obtuse, never cuspidate. Flower-clusters $0.5-3 \mathrm{~mm}$ apart, 1-2-flowered; cluster axis $0.2-0.7 \mathrm{~mm}$ long, cylindrical, moderately slender; longer cluster axes often with lateral flower closer to base than apex. Cluster-bract very short, rounded or minutely apiculate. Bracteoles not detectable.

Flowers: Anthopodium c. $0.5 \mathrm{~mm}$ long, bulging downward at base. Sepals membranous, closely appressed to petals, connate for over $1 / 2$ their length with very broad shallow sinuses, triangular, acute. Petals c. $1.2 \mathrm{~mm}$ long, rather narrowly triangular-ovate, acute and cymbiform at apex; inner face with 3 fairly deep cavities. Stamens at least $3 / 4$ as long as petals, connate for c. $1 / 4$ their length; filaments broadly triangular-ovate, tapering smoothly to an elongated slender apex. Carpels not seen. Fruit (only immature and long-fallen fruits seen) spherical-ellipsoid, strongly flattened adaxially, c. $11 \mathrm{~mm}$ long, $10 \mathrm{~mm}$ diameter, abruptly narrowed at base into a very short 
conical extension, ventral suture evident. Epicarp reddish-brown (immature, dry) or grey-brown (fallen), minutely verruculose. Mesocarp apparently very thin, deep red-brown on inner surface. Endocarp c. $0.15 \mathrm{~mm}$ thick. Seed c. $9 \mathrm{~mm}$ long, flattened on adaxial face. Intrusion penetrating from lateral position for $1 / 4$ to $1 / 2$ seed diameter, in 1.s. with very narrow base and small lobes directed away from embryo. Embryo sub-basal. (Fig. 1b, 4f, 17c)

Distribution: confined to the region of the border between the Northern Territory and Western Australia, north of about $18^{\circ}$ latitude. It is abundant in the vicinity of the middle and lower parts of the Victoria River (downstream of Victoria River Downs Station), and much of the Ord River basin, though apparently not downstream of Kununurra. Two sites where it occurs in great abundance are the Bungle Bungles, south of Lake Argyle, and Jasper Gorge, a western tributary of the Victoria River a short distance north of Victoria River Downs. To the northeast, populations of what is very likely this palm were seen from the air on ranges forming the watershed between the Fitzmaurice and Katherine Rivers. For references to possible southern extensions of its range see Note 4 below.

Ecology: apparently virtually confined to sandstone range country, where it grows in rocky ravines, on slopes below cliffs, on cliff ledges, and less commonly along gravelly or sandy watercourses, all habitats where there is permanent seepage water available to its roots. Trees with which it is commonly associated include Corymbia aspera, Ficus leucotricha, Terminalia canescens, Owenia vernicosa, Gardenia spp. and Acacia spp. The dominant grass is nearly always Triodia.

Conservation status: although this species has received the coding $3 \mathrm{KC}-$ (Briggs \& Leigh 1996), it is now known to occur in very large populations, with many local concentrations scattered over a considerable area of the Ord and Victoria River catchments, mostly on rocky, inaccessible sites and it is very adequately conserved in the Bungle Bungle-Purnululu National Park (WA) and the Gregory National Park (NT). For these reasons is should be regarded as 'not at risk' and should no longer have a ROTAP listing.

Specimens examined: Northern Territory: Victoria River: Yambarran Range, Leach 4554 \& Walsh, 16 May 1994 (DNA, NSW,BRI, MEL); N side of Jasper Gorge, upper slope below cliffs of sandstone, McGillivray 3804 E George, 15 June 1978; Jasper Gorge, Parker 1065, 13 July 1977 (DNA, NSW); Byrnes 1718, 17 Sep 1969 (DNA, CANB, PERTH); 5 km E of Victoria River crossing, Maconochie 2493, 8 Oct 1980 (DNA, NSW).

Western Australia: Gardner: Ord River Basin, Koford \& Dortch 120, Sep 1974 (PERTH); Tributary of Keep River, Lullfitz s.n., Nov 1978 (DNA, NSW); Thompson Spring, c. 40 km SE of Kununurra, Ryan s.n., 6 June 1979 (PERTH, NSW); 7 miles [11.3 km] E of Denham [=Dunham?] River Station, Perry 2529, 19 July 1949 (CANB, NSW); Cabbage Tree Creek, Carr Boyd Ranges, E Kimberleys, Rodd 2800, 17 Oct 1974 (NSW, K, PERTH); Carr Boyd Range, Wyndham to Halls Creek road, Hand s.n., 1978 (NSW 108860b); near Lucky Hill, 23 km NNE of Dunham River HS., NE Kimberleys, Lazarides 8552, 13 Mar 1978 (CANB, K, PERTH); Piccaninny Creek Gorge, 15 km SE of Bungle Bungle Outcamp, Bungle Bungle Range, NE Kimberley, Blackwell BB419, 6 Apr 1985 (PERTH); Bungle Bungle Range, gorge 3 km SE of Bungle Bungle Outcamp, Kenneally 9260, 8 July 1984 (PERTH); Gallery Forest 16 km NE of Bungle Bungle Outcamp, E Kimberley, Kenneally 9212, 5 July 1984 (PERTH); Frog Hole Canyon, N end of Bungle Bungle Range, Briggs 93071 Aug 1994 (NSW); Gorge off Piccaninny Creek, Bungle Bungle Range, Briggs 9309, 5 Aug 1994 (NSW); Teroni Gorge, 12 miles [19 km] NNW of Elgie Cliffs Station, E Kimberleys, Lazarides 6395, 22 July 1959 (CANB); Bens Springs, 3 km E of El Questro homestead, Kenneally 10965, 29 June 1989 (PERTH, NSW).

\section{Notes}

1. A well-marked species showing clear morphological and geographical demarcation from others in the region. In leaf characters it approaches most closely to L. alfredii, differing slightly but consistently in depth of lobing and bifurcation of segments; 
the trunk is also more slender. The large inflorescences, ramified to 5 orders and with most rachillae extremely short $(4-10 \mathrm{~mm})$, together with the small fruits, and seeds with small endosperm intrusion, combine to make this a very distinctive species.

2. The epithet victoriae alludes to its occurrence in the vicinity of the Victoria River, but the genitive form is used to complete a trio with L. alfredii and L. mariae, named respectively for Queen Victoria's son and daughter-in-law and occurring more or less equidistant from the present species in similarly semi-arid habitats.

3. It is puzzling that this has remained unrecognised as a species for so long, or indeed not even represented by any herbarium collection until Perry's in 1949. It must have been a familiar plant to pioneer pastoralists of the eastern Kimberley Region from the 1880s onward. Further, Mueller himself must have seen it in the course of his journey up the Victoria River with Gregory in 1854.

4. In his autobiographical book, Boss Drover, Keith Willey (1971: 113) refers to the former presence of native palms 'at Lewis Creek and in isolated places in the desert', and to 'groves of them at Flora Valley and Sturt Creek but the pioneers cut them all down to build sheds and yards.' These three localities are all in Western Australia not far from the Northern Territory border between $18^{\circ} 10^{\prime}$ and $19^{\circ} 10^{\prime} S$, much further south than any of the collections cited here. He also mentions a solitary, tall palm at 'Palm Spring' on Montejinnie Station, which is ESE of Victoria River Downs. From his descriptions of the trunks these palms could well be L. victoriae, though L. mariae is another possibility.

5. Wilson (1992) describes the fruit as 'black, globular, ca $15 \mathrm{~mm}$ across'. Fresh mature fruits may be somewhat larger than dry ones, but I have not seen fruits of such a large diameter nor any that are quite black in colour in the dry state. Briggs 9307 from the Bungle Bungle Range has apparently mature fruits - though described by the collector as 'green' (August), when dry they had turned chestnut-brown with closely wrinkled skin; they conform to the previously recorded dimensions of $11 \mathrm{~mm}$ length and $10 \mathrm{~mm}$ diameter. B. Briggs (pers. comm.) considered that fruit colour was a consistent feature distinguishing the green-fruited Bungle Bungle palms from the black fruited plants of L. eastonii on the Mitchell Plateau. Maconochie 2493 bears the label note 'Fruit globular, green, drying black, thin pericarp.' But the dried fruits of his specimen, apparently virtually mature judging by the hardness of the endosperm, are a somewhat reddish-tan with closely wrinkled skin.

\section{L. alfredii F. Muell.}

Mueller (1892: 112; 1893: 28); Drude (1893: 12); Dammer (1905: 297); Fitzgerald (1918: 24 p.p.); Beccari (1921: 18; 1931: 82, t.6).

Type: Western Australia: Millstream, Hamersley Range, J. Forrest, 1883(?); holo MEL.

[L. mariae F. Muell. (1878), as to specimens from Fortescue River, W.A.]

Trunk solitary, to 10 or possibly $12 \mathrm{~m}$ tall, $30-35 \mathrm{~cm}$ diameter at $1 \mathrm{~m}$ above ground, broadening more or less abruptly at base, often with flaring rim of corky plates above conical root mass up to $30 \mathrm{~cm}$ high. Surface closely ringed with sinuous scars, somewhat bulging between these to give a transversely corrugated appearance; vertical fissures close-set, deep, somewhat zig-zagging; basal 1-2 $\mathrm{m}$ of trunk bearing persistent, irregularly broken-off petiole stubs $3-5 \mathrm{~cm}$ long, or sometimes whole dead leaves.

Crown globose, moderately dense, consisting of c. 25-30 leaves, the petioles mostly gently recurved, usually with a few dead leaves hanging vertically below. Ligules fairly prominent, with smooth, almost unbroken surface, very pale buff-coloured, whitish scurfy-tomentose. 
Petiole 90-130 cm long, 24-33 mm wide; flattened-triangular in t.s. with rounded keel. Margins almost completely smooth or armed with irregularly scattered narrow, patent, bluntish prickles under $2 \mathrm{~mm}$ long. Surfaces pale pinkish-green ageing to pinkish-brown, smooth, pruinose with hard waxy feel, on younger leaves densely clothed in minute white waxy appressed scales with patchily distributed tufts of spirally coiled white laciniae up to $3 \mathrm{~mm}$ long, arising from dark brown basal-masses in regularly distributed linear pits about $2 \mathrm{~mm}$ long, more numerous on abaxial surface, the waxy scales persisting but losing their laciniae. Hastula short and broad; base obliquely V-shaped or somewhat cuspidate; rim at about $45^{\circ}$ to costa, $5-10 \mathrm{~mm}$ wide, \pm flat, continuous or split at apex, early-necrotic.

Lamina 90-140 cm long, 0.40-0.45 mm thick, strongly costapalmate, truncate at base (lowermost segments spreading at right-angles to petiole), rather harsh and rigid; fairly strongly contorted with 2 adaxial undulations either side of the gently deflexed costa. Segments about 28-33 either side of costa; largest segments 25-42 mm wide, free for $60-70 \%$ of their length, bifurcated for $60-75 \%$ of free length, the lobes slightly diverging, tapering evenly and gradually, attenuated into very fine threadlike apices. Intersegmental appendages threadlike, up to c. $5 \mathrm{~cm}$ long. Ribs: abaxial ribs in t.s. trapeziform (narrowing slightly to lamina) sharply square-edged, up to $1.0 \mathrm{~mm}$ thick, $2.0 \mathrm{~mm}$ deep; adaxial ribs similar or slightly shallower. Venation: major longitudinal veins 8-10 either side of abaxial rib, not very prominent above, even less so beneath; transverse veins barely visible. Surfaces concolorous, pallid grey-green with waxy bloom (bluish in field), minute disc-like wax flakes persisting in the fine striations on older leaves, virtually glabrous except for scattered scales near bases of abaxial ribs.

Inflorescences apparently dimorphic, on fruit-bearing trees \pm equalling leaves, on 'male' trees hardly exceeding petioles. Partial inflorescences 5-7(?), subequal; each branched to 2 ('female') or 3 ('male') further orders; rachillae to $13 \mathrm{~cm}$ long, $0.7-1.2 \mathrm{~mm}$ thick, uniformly deep dull pink or cream suffused pink, with whitish pruinosity. Rachis bracts smoothly cylindrical but mostly irregularly torn a little below apex revealing net of brown fibres, $2.5-3 \mathrm{~cm}$ diameter, hard, leathery, reddish-brown often becoming whitish-necrotic, those on 'female' inflorescences more tightly sheathing and on 'male' somewhat loose and wrinkled, bearing a sparse to moderately dense indumentum of short pale brown scales in a fine pattern of tufts, often scurfy and whitish on upper half; bract apices long, narrowly triangular or slightly cuspidate, glabrescent. Flower-clusters 1-5 mm apart, 1-2-flowered (nearly always 1-flowered on 'female' inflorescences); cluster axis (in 'female') present only as a pad with fleshy lobes protruding between bracts or (in 'male') about $0.5 \mathrm{~mm}$ long, knob-like. Cluster-bract minute, triangular, apiculate. Bracteoles 1-3 detectable as narrow, apiculate rims.

Flowers 2-3 mm long, \pm cylindrical to funnel-shaped. Anthopodium $0.3-1.0 \mathrm{~mm}$ long (shorter on 'male' flowers), mostly thicker than long, bulging downward at base over cluster axis. Sepals closely appressed to petals, with broad hyaline margins, $0.8-1.0 \mathrm{~mm}$ long, triangular-ovate to broadly triangular. Petals $2.0-3.0 \mathrm{~mm}$ long, triangular-ovate, slightly cymbiform but only at extreme apex, minutely auriculate at base, inner faces with distinct but shallow cavities. Stamens c. $2 / 3$ as long as petals; filaments broadly triangular-ovate narrowing smoothly into acuminate apex, not shouldered; anthers c. $0.4 \mathrm{~mm}$ long. Carpels c. $3 / 4$ as long as stamens; ovaries closely pressed together along inner faces, plump and gibbous on abaxial side, abruptly contracted into very short, inward-pointing styles.

Fruit spherical, 25-35(-c. 40) mm diameter; base with shallow conical extension; apex with stigmatic remains evident as smaller conical projection, adaxially displaced. Epicarp red-brown to dark brown, smooth when fresh, finely wrinkled when dry, with pale brown lenticels in the form of circular blisters $0.3-0.5 \mathrm{~mm}$ diameter with central pit, evenly dispersed at 1-2 mm intervals. Mesocarp said to be thick and juicy when fresh, when dry c. $1.5 \mathrm{~mm}$ thick. Endocarp c. $0.2 \mathrm{~mm}$ thick, very brittle, pale buff-coloured. 
Seed near-spherical, 17-20 mm diameter (dry), testa 0.4-0.6 mm thick, its surface pale buff-coloured and verruculose, with a deeper red-brown hilum. Intrusion penetrating from a near-basal position, 6-8 $\mathrm{mm}$ diameter at base, expanding to only slightly wider in centre to fill much of centre, leaving shell of endosperm $3-5 \mathrm{~mm}$ thick, irregularly but shallowly lobed. Embryo in near-apical position. (Fig. 4e, 15b, 18)

Distribution: Western Australia, Hamersley Region, Fortescue River in vicinity of Millstream, also head of Ashburton River and its tributary Duck Creek; recently discovered is a relict stand of a few trees in the Cape Range, on the west side of Exmouth Gulf.

Ecology: appears to be restricted to alluvium along rivers, smaller streams and beds of ravines where moisture is permanently available at least in the form of steam-bed soaks. In southern tributaries of the Millstream portion of the Fortescue River it forms dense populations in shallow ravines in soft concreted sediments, their beds with permanent small pools of highly mineralised and somewhat saline water edged with white incrustations. Associated trees include Eucalyptus camaldulensis and Melaleuca leucadendra.

Conservation status: 3RC- (Briggs \& Leigh 1996). A substantial proportion of the populations of the species lies within Millstream Chichester National Park.

Specimens examined: Western Australia: Fortescue: On the 'Mill-Stream' of the Fortescue River, Forrest 301, June 1878 (MEL); Hamersley Range, Forrest 1879 (MEL) [label worded thus in Mueller's hand, but also present is a piece of original wrapping paper marked: 'Botanical specimen, flower of the Marie Livistona Palm, Survey Office, Perth 19 Feb 79.' This collection consists of pieces of inflorescence and a packet of flowers]; Millstream, Hamersley Range, Forrest (MEL) [a half-leaf and a packet of dissected seeds, with various slips of paper including notes on nomenclature, possibly in Ewart's hand]; Millstream, Hamersley Range, anon (Beresford?), 1892 [1 fruit in packet] (MEL); Millstream, Fortescue River, George 3523, 3 Mar 1962 (PERTH); Beauglehole s.n., Aug 1974 (PERTH); Brooker 2064, 24 Sep 1969 (PERTH); 'Millstream' Station, Rodd 2847, 20 Oct 1974, [in homestead garden, presumed part of natural vegetation] (NSW, PERTH, K, BH); loc. cit., Rodd 2848, 2849, 20 Oct 1974 (NSW, PERTH); Longreach, Millstream, Fortescue River, Gardner s.n., 21 Aug 1932 (PERTH); Duck Creek c. 32 km W of 'Mount Brockman' Station, Wark spec. A, spec. B, 3 May 1975, (NSW). Carnarvon: Cape Range, North West Cape, Waldock s.n., 29 Sep 1988 (PERTH, photo NSW).

\section{Notes}

1. This is the most isolated and one of the most geographically restricted of all the Australian species. Its major occurrence at Millstream is spread along about $15 \mathrm{~km}$ of the Fortescue River and the lowest few kilometres of its tributary creeks on the southern side, coinciding with the surfacing of a strongly discharging artesian aquifer yielding water of appreciable salinity and alkalinity.

2. The other major occurrences known are on Duck Creek, a tributary of the upper Ashburton River, where Mr R.J. Wark reports there are possibly up to 1000 plants, and at Silver Grass Pool on the upper Robe River, reported to Mr Wark by the owners of Mt Brockman Station.

3. In 1989 Mr Kevin Kenneally of the Western Australian Herbarium reported to me the discovery by a group of zoologists from the Western Australian Museum in September 1988 of a few palms clinging precariously to life in a remote gully of the Cape Range, which runs south from North West Cape; a specimen forwarded to me has been identified as L. alfredii, and this site represents an extension of its range by approximately $300 \mathrm{~km}$ to the west. From the coordinates supplied the locality appears to be southwest of Learmonth and not within the Cape Range National Park.

4. Mueller's first (and only) use of the name 'L. Alfredi' in 1892 in the Victorian Naturalist is taken as valid publication of this species, and is cited as the place of publication in Index Kewensis and by Beccari (1921, 1931), Moore (1963a) and Chapman (1991). 
It is, however, in the nature of an informal report rather than a botanical description. The only parts in it that provide any sort of diagnosis are contained in the words: 'This particular characteristic [i.e. juvenile leaves being 'a rich bronzy colour'] seems neither to apply to the West-Australian species ...', and '... I have always found transmitted fruitlets considerably larger than those of the genuine L. Mariae, and further some minor differences exist also in the flowers of the two species, as recently ascertained.' He continues: 'The West-Australian Fan-Palm has now been named L. Alfredi, in honour of H.R.H. the Duke of Edinburgh, at whose nuptial festival the Central Australian Palm became dedicated to the Princess Marie of Russia.' It can be argued, however, that the whole article contains an implied reference to the Millstream element in Mueller's 1878 description of L. mariae (based on a leaf specimen from the 'Glen of Palms' and inflorescence and fruit from 'The Millstream', and hence constitutes valid publication. As noted under L. mariae, the 1892 note certainly signified Mueller's intention to restrict the application of his name to the Central Australian species, and thus might at least be construed as a sort of lectotypification of that species.

5. Index Kewensis cites, in addition to the Victorian Naturalist note, an additional publication of the name by Mueller in Botanisches Zentralblatt in 1893. This is merely a verbatim transcript (still in English) of the Victorian Naturalist note.

6. If the argument is not accepted that Mueller's 1892 publication was valid, then the next significant use of the name was by Drude in 1893, in an article entitled 'Über die australischen Livistona-Arten', in Beiblatt zu den Botanischen Jahrbüchern, Nr. 39. In German with a Latin key, this separates L. alfredii into the monotypic Sect. Gregorya, defined entirely on characters of fruit and seed (particularly the raphe), and the key supplies a reasonable diagnosis based on these characters.

7. Beccari's posthumous 1921 (brief Latin) and 1931 (lengthy English) accounts of the old-world coryphoid palms also provide adequate diagnoses of this species. But even his description is based on only two collections, one by Forrest from Millstream (date not cited), the other from 'Nickol Bay' by McRae, dated 1879. There has been no more recent confirmation of its occurrence at the latter locality (near the towns of Roebourne and Karratha), and it can probably be treated as a shorthand designation for a large hinterland, including the Millstream area.

8. Fitzgerald (1918) reported L. alfredii from 'Millstream, Fortescue River (Alex. Forrest), Mts Herbert, Broome, Leake and Barnett; Isdell, Harris and Phillips Ranges; hills near the junction of Hann and Barnett Rivers (W.V.F.) ...' All except the first of these are localities are in the Kimberley Region, and the palms occurring there are most unlikely to fall within the concept of L. alfredii adopted herein. They are most likely L. kimberleyana Rodd.

9. Gardner (1923) interpreted L. alfredii in a way which cannot possibly be sanctioned by the ICBN, even as it existed then. Under this name he cites a number of localities, all in the Kimberley Region. In the present treatment these would probably, like Fitzgerald's citations, represent L. kimberleyana, which could conceivably be included within a very broad concept of $L$. alfredii. But, under the heading 'L. mariae F.v.M.' he cites a collection from 'the Millstream Station'! In effect he was preserving Mueller's early (1878) concept of L. mariae encompassing both the Macdonnell Range and the Millstream palms, and at the same time displacing the application of L. alfredii from its type locality of Millstream (Mueller 1892, Drude 1893) to occurrences in the Kimberleys.

10. Colour of the fruit when fresh and fully ripe has not been observed at first hand, but at the time of my visit to 'Millstream' Station I was informed by the owners that the fruits ripened to black or purplish-black and were quite juicy, 'like a plum'. 


\section{Acknowledgments}

Peter Wilson, Barbara Briggs and Barbara Wiecek assisted and persevered in the final stages of preparing the manuscript. Angela Benn and Sue McCahon typed the manuscript. Robert Roden was responsible for the illustrations. Don McGillivray, Barry Conn and Ken Hill obtained photographs of type specimens and other valuable information while in Europe as Australian Botanical Liaison Officers. Especially relevant were collections and information from Tony Irvine and John Dowe. Surrey Jacobs, Clyde Dunlop, Mick Jackes, Peter Lavarack, the late John Maconochie and the Benedictine Community at Kalumburu facilitated the field studies. My 1974 field trip around northern Australia would not have been possible without the use of a light plane piloted by my friend Kel Stillman. Karen Wilson drew my attention to the book Boss Drover, with mention of palms in the southern Kimberley. The Directors of herbaria in Australia and abroad provided loans of relevant specimens. Funding for fieldwork and technical assistance was provided by a grant from the Australian Biological Resources Study, the Royal Botanic Gardens and Domain Trust and Dames and Moore Consulting. My thanks go to them all.

\section{References}

Arber, A. (1922) On the development and morphology of the leaves of palms. Proc. Roy. Soc., ser. B, 93: 249-261.

Bailey, F.M. (1898) Contributions to the flora of Queensland. Queensland Agric. J. 2: 129-133.

Bailey, F.M. (1902) Livistona. Queensland Flora 5: 1683-1684.

Bailey, L.H. (1933) Palms and their characteristics. Gentes Herb. 3(1): 3-29.

Bailey, L.H. (1935) The King Palms of Australia. Gentes Herb. 3(8): 391-409.

Bailey, L.H. (1939) Howea in cultivation. — The Sentry Palms. Gentes Herb. 4(6): 189-198.

Baines, J.A. (1981) Australian plant genera: an etymological dictionary of Australian plant genera (Society for Growing Australian Plants).

Beard, J.S. (1976) The monsoon forests of the Admiralty Gulf, Western Australia. Vegetatio 31(3): 177-192.

Beccari, O. (1908) Asiatic palms - Lepidocaryeae, Part 1. The species of Calamus. Ann. Roy. Bot. Gard. (Calcutta) 11: 1-578.

Beccari, O. (1910) La "Copernicia cerifera" in Riviera ed una nuova specie di Livistona. Webbia 3: 295-305.

Beccari, O. (1921) Recensione delle palme del vecchio mondo appartenenti alla tribu delle Corypheae, con descrizione della specie e varieta nuove che vi appartengono. Webbia 5: 5-70.

Beccari, O. (1931) Asiatic palms - Corypheae. Ann. Roy. Bot. Gard. (Calcutta) 13: 1-356.

Bentham, G. (1878) Livistona. Flora australiensis 7: 145-147. (Lovell Reeve \& Co.: London).

Birch, J. \& Dowe, J.L. (1989) Livistona inermis R. Br. in Queensland. Palms \& Cycads 22: 11-16.

Blake, S.T. (1954) Botanical contributions of the Northern Australian Regional Survey II. Studies on miscellaneous northern Australian plants. Austral. J. Bot. 2(1): 99-140.

Blombery, A.M. \& Rodd, A.N. (1982) Palms. (Angus \& Robertson: Sydney).

Briggs, B.G., \& Johnson, L.A.S. 1979. Evolution in the Myrtaceae - evidence from inflorescence structure. Proc. Linn. Soc. New S. Wales 102: 157-256.

Briggs, J.D., \& J.H. Leigh (1996) Rare or threatened Australian Plants, revised edition. (CSIRO Publishing: Collingwood).

Brown, R. (1810) Prodromus florae Novae Hollandiae et insulae Van-Diemen (J. Johnson \& Co.: London).

Burret, M. (1935) Neue Palmen aus Neuguinea II. Notizbl. Bot. Gart. Berlin-Dahlem 12 (113): 309-348.

Burret, M. (1939) Palmae gesammelt in Neu Guinea von L.J. Brass. J. Arnold Arbor. 20: 187-212.

Burret, M. (1941) Bemerkungen zur Palmengattung Livistona R. Brown. Notizbl. Bot. Gart. BerlinDahlem 15: 319-327.

Chapman, A.D. (1991) Australian Plant Name Index. Australian Flora and Fauna Series No. 11. (Australian Government Publishing Service: Canberra).

Cornett, J.W. (1986) Spineless petioles in Washingtonia filifera (Arecaceae). Madroño 33: 76-78.

Covacevich, J.M. \& Covacevich, J. (1978) Palms in northeastern Australia I. Species from Iron Range, far northeastern Queensland. Principes 22: 88-93. 
Dammer, U. (1905) Garden palms. Gard. Chron. ser. 3, 38: 297.

Domin, K. (1915) Beiträge zur Flora und Pflanzengeographie Australiens. Biblioth. Bot. 20(85, 2): 243-554.

Dowe, J.L. (1990) Ecological status and endangerment of Australian palms. Palms \& Cycads no. 26: 2-7.

Dowe, J.L. (1995) A preliminary review of the biogeography of Australian Arecaceae. Mooreana 5: $7-22$.

Dowe, J.L. \& Hodel, D.R. (1994) Revision of Archontophoenix H. Wendl. \& Drude (Arecaceae). Austrobaileya 4 (2): 227-244.

Dowe, J.L. \& Irvine, A.K. (1997) A revision of Linospadix in Australia, with the description of a new species. Principes 41: 192-197, 211-217.

Dransfield, J. (1977) A dwarf Livistona (Palmae) from Borneo. Kew Bull. 31: 759-762.

Dransfield, J. (1987) Bicentric distribution in Malesia as exemplified by palms. In Whitmore, T.C. (ed.) Biogeographical Evolution of the Malay Archipelago (Clarendon Press: Oxford).

Dransfield, J., Irvine, A.K. \& Uhl, N.W. (1985) Oraniopsis appendiculata, a previously misunderstood Queensland palm. Principes 29: 56-63.

Dransfield, J. and Wong, K.M. (1987) A new species of Livistona (Palmae) from Peninsular Malaysia. Mal. Nat. J. 41: 119-123.

Drude, O. (1893) Über die australischen Livistona-Arten. Bot. Jahrb. Syst. 16, Beiblatt 39: 5-12.

Eames, A.J. (1953) Neglected morphology of the palm leaf. Phytomorphology 3: 172-189.

Essig, F.B. (1978) A revision of the genus Ptychosperma Labill. (Arecaceae). Allertonia 1: 415-478.

Evans, O.D. \& Johnson, L.A.S. (1962) 21. Palmae. Contr. New South Wales Natl Herb., Fl. Ser. 21-22: $1-6$.

Fitzgerald, W.V. (1918) The botany of the Kimberleys, North-West Australia. J. E Proc. Roy. Soc. Western Australia 3: 102-224.

Gardner, C.A. (1923) Botanical notes, Kimberley Division of Western Australia. Forests Department Bulletin No. 32. Perth.

Hall, N. (1978) Botanists of the Eucalypts. (CSIRO: Melbourne).

Hallé, F., Oldeman, R.A.A. \& Tomlinson, P.B. (1978) Tropical Trees and Forests: an architectural analysis. (Springer: Berlin).

Hnatiuk, R. (1977) Population structure of Livistona eastonii Gardn., Mitchell Plateau, Western Australia. Austral. J. Ecol. 2: 461-466.

Hooker, J.D. (1877) Livistona australis. Bot. Mag. 103: t. 6274.

Irvine, A.K. (1983) Wodyetia, a new arecoid genus from Australia. Principes 27: 158-167.

Johns, R.J. \& Hay, A.J.M. (1984): A Guide to the Monocotyledons of Papua New Guinea, part 3. (Department of Forests: Lae)

Johnson, R.W. (1980) The Queensland palm flora. Queensland Naturalist 23: 10-20.

Jones, D.L. (1984) Palms in Australia. (Reed Books: Frenchs Forest).

Jones, D.L. (1995) Palms throughout the World. (Reed Books: Chatswood).

Kaplan, D.R., Dengler, N.G. \& Dengler, R.E. (1982) The mechanism of plication inception in palm leaves: histogenic observations on the palmate leaf of Rhapis excelsa. Canadian J. Bot. 60: 2999-3016.

Kerchove de Denterghem, O. de (1878) Les Palmiers, Histoire Iconographique. (Paris)

Lamarck, J.B.A.P.M. de (1786) Coryphe. Encyclopédie Méthodique. Botanique 2: 130-131.

Latz, P.K. (1975) Notes on the relict palm Livistona mariae F. Muell. in Central Australia. Trans. Roy. Soc. South Australia 99: 189-195.

Liddell, H.G. \& Scott, R. (1864) A Greek-English Lexicon. (Clarendon: Oxford).

Linnaeus, C. (1753) Species plantarum, 2 vols. (Laurentius Salvius: Stockholm).

Lothian, N. (1958) The Livistonas of Australia. With particular reference to the Central Australian Cabbage Palm. Principes 2: 92-94.

Maiden, J.H. (1921) Forest Flora of New South Wales 7: 353, t. 256 (Government Printer: Sydney).

Martius, C.F.P. von (1838) Historia Naturae Palmarum, vol. 3 (Part 7).

Moore, C. \& Betche, E. (1893) Handbook of the Flora of New South Wales (Government Printer: Sydney).

Moore, H.E. (1963a) An annotated checklist of cultivated palms. Principes 7: 119-182.

Moore, H.E. (1963b) The types and lectotypes of some palm genera. Gentes Herb. 9: 245-274.

Moore, H.E. (1965) Palm hunting around the world. III. Sabah and Australia. Principes 9: 138-152.

Moore, H.E. (1973) Livistona brassii, L. crustacea and L. muelleri. Principes 17: 60.

Moore, H.E. \& Dransfield, J. (1979) The typification of Linnaean palms. Taxon 28: 59-70. 
Mueller, F. (1865) Fragmenta phytographiae australiae, vol. 5.

Mueller, F. (1874) Fragmenta phytographiae australiae, vol. 8.

Mueller, F. (1875) Plants collected by Mr Giles during his geographic exploration of Central Australia in 1872, 1873 and 1874. Pp. 209-223 in E. Giles, Geographic Travels in Central Australia from 1872 to 1874. (M'Carron, Bird \& Co.: Melbourne).

Mueller, F. (1878) Palmae. Fragmenta phytographiae australiae 11: 54-58.

Mueller, F. (1879) Livistona mariae. Gard. Chron. ser. 2, 11: 790.

Mueller, F. (1892) Note on the West Australian fan-palm. Victorian Naturalist 9: 112.

Mueller, F. (1893) Note on the West Australian fan-palm. Bot. Zentralbl. 53: 28.

Orscheg, C.K. \& Parsons, R.F. (1996a) Ecology of Livistona australis (R. Br.) Martius (Arecaceae) at its southern limit, south-eastern Australia. Part I. Distribution and genetic variation. Mooreana 6: $8-17$.

Orscheg, C.K. \& Parsons, R.F. (1996b) Ecology of Livistona australis (R. Br.) Martius (Arecaceae) at its southern limit, south-eastern Australia. Part II. Phenology, germination, herbivory, regeneration and fire effects. Mooreana 6: 36-50.

Rheede tot Draakestein, H. van (1682) Hortus Indicus Malabaricus 3: 1-6, pl. 1-12.

Rodd, A.N. (1983) Palmae. Pp. 392-395 in B.D. Morley \& H.R. Toelken, Flowering Plants in Australia. (Rigby: Adelaide).

Specht, R.L. (1958) The Gymnospermae and Angiospermae collected on the Arnhem Land Expedition. Pp. 185-317 in Specht, R.L. \& Mountford, C.P. (eds.), Records of the AmericanAustralian Scientific Expedition to Arnhem Land, vol. 3, Botany and plant ecology. (Melbourne University Press: Melbourne).

Tomlinson, P.B. (1961) Anatomy of the Monocotyledons, II. Palmae. (Clarendon Press: Oxford).

Tomlinson, P.B. (1964) The vascular skeleton of coconut leaf base. Phytomorphology 14: 218-230.

Tomlinson, P.B. (1971) Flowering in Metroxylon (the sago palm). Principes 15: 49-62.

Tomlinson, P.B. (1990) The Structural Biology of Palms. (Clarendon Press: Oxford).

Tomlinson, P.B. (1995) The leaf base in palms: structural and functional aspects. Giorn. Bot. Ital. 129: 466-479.

Tomlinson, P.B. \& Moore, H.E. (1968) Inflorescence in Nannorrhops ritchiana (Palmae). J. Arnold Arbor. 49: $16-34$.

Tomlinson, P.B. \& Soderholm, P.K. (1975) The flowering and fruiting of Corypha elata in South Florida. Principes 9(3): 83-99.

Tralau, H. (1964) The genus Nypa van Wurmb. Kongl. Svenska Vetenskapsakad. Handl., ser. 4, 10(1): $1-29$.

Tucker, R. (1980) Notes on the palms of northwestern Cape York Peninsula. Principes 24: 99-104.

Uhl, N.W. \& Dransfield, J. (1987) Genera Palmarum. (Allen Press: Lawrence, Kansas).

Uhl, N.W. (1969) Anatomy and ontogeny of the cincinni and flowers in Nannorrhops ritchiana (Palmae). J. Arnold Arbor. 50: 411-431.

Waterhouse, J.T. \& Quinn, C.J. (1978) Growth patterns in the stem of the palm Archontophoenix cunninghamiana. Bot. J. Linn. Soc. 77: 73-93.

Wei, X.W. \& Xiao, M.Y. (1982) A new species of Livistona from China. J. S. China Agric. Coll. 3: 22-24.

Wendland, H.A. \& Drude, O. (1875) Palmae australasicae. Linnaea 89(2): 153-238.

Wendland, H.A. (1878) in Kerchove de Denterghem, O. de, Les Palmiers: Histoire Iconographique. (Paris)

Whitmore, T.C. (1973) Palms of Malaya. (Oxford University Press: Petaling Jaya, Malaysia)

Wilson, A.J.G. (1992) Family 167. Arecaceae (Palmae). Pp. 1249-50 in Wheeler, J.R., Rye, B.L. \& Koch, B.L., Flora of the Kimberley Region. (Western Australian Herbarium: Perth).

White, A. (1988) Palms of the Northern Territory. (Palm \& Cycad Societies of Australia: Milton).

Willey, K. (1971) Boss Drover. (Rigby: Adelaide). 

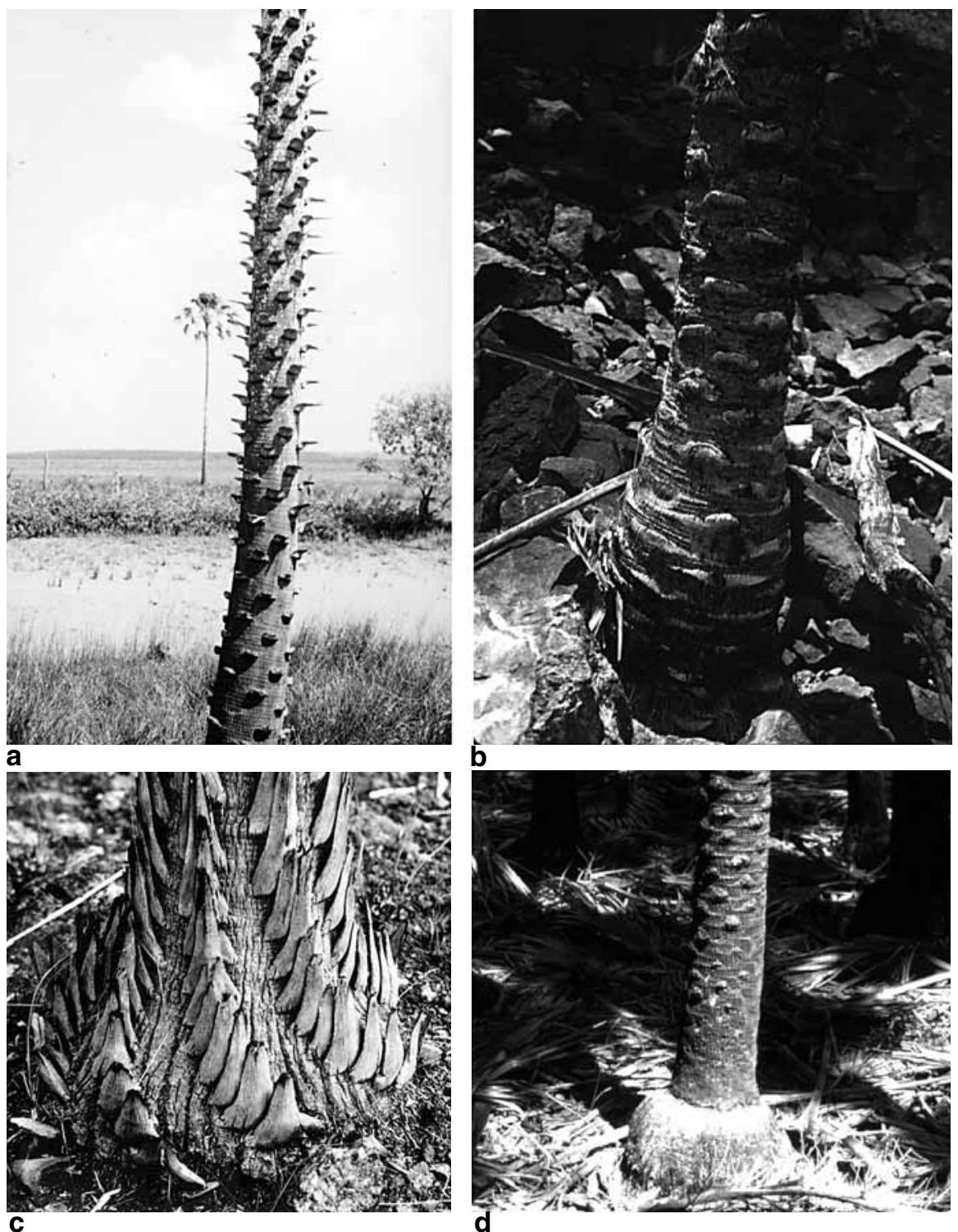

Fig. 1. Trunks showing petiole stubs. a, L. benthamii, Adelaide R. crossing Arnhem Highway Northern Territory. b, L. victoriae, Victoria R. crossing, Northern Territory. c, L. eastonii, Mitchell Plateau, north Western Australia. d, L. muelleri, Silver Plains, Queensland. 

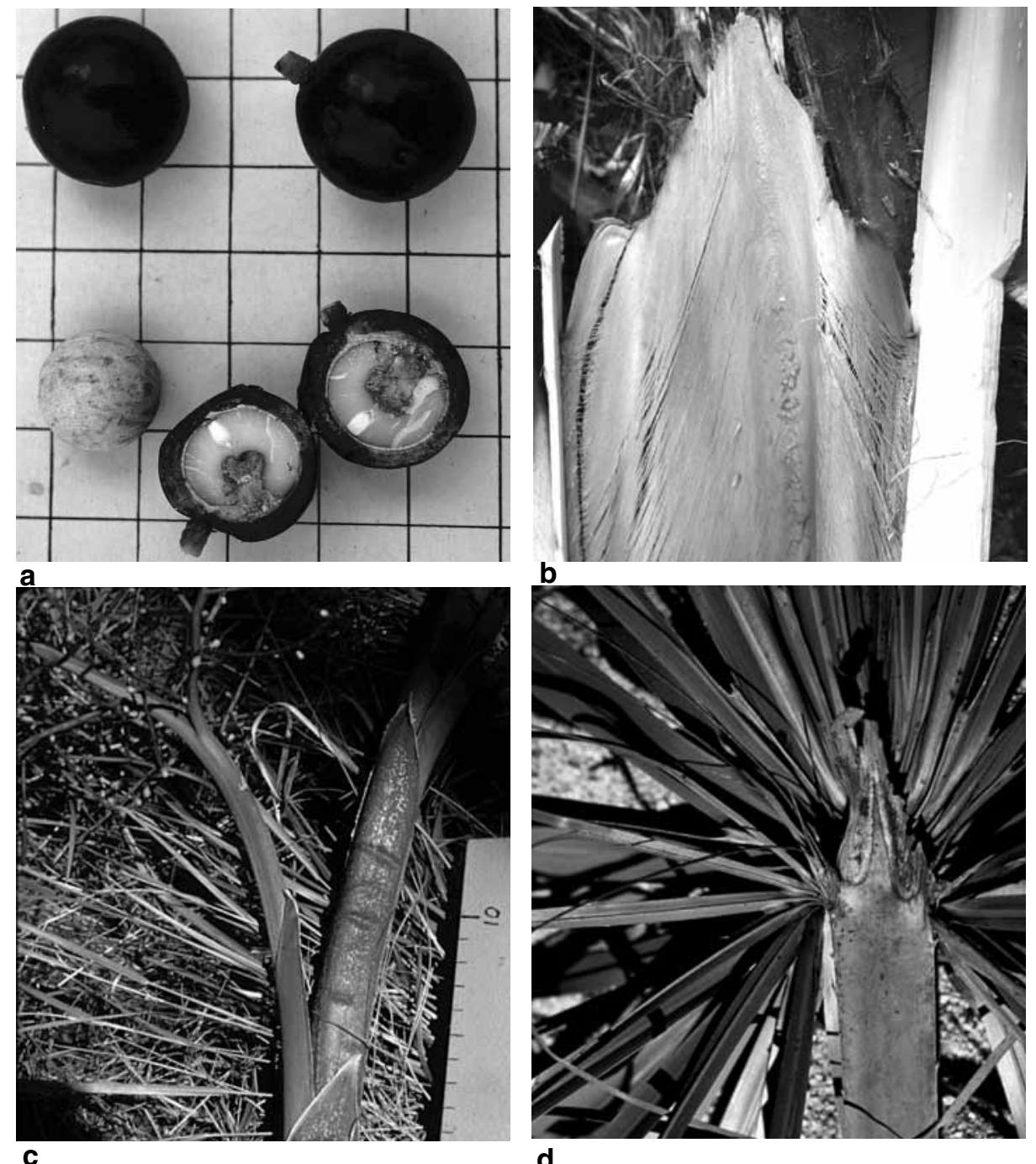

d

Fig 2. a, b, L. nitida, Delusion Creek Creek-Dawson R. junction, Queensland: a, fruits: whole, split longitudinally, and endocarp stripped of mesocarp ( $1 \mathrm{~cm}$ grid); $\mathbf{b}$, ligule of young leaf opened flat (note overlapping petiole margin lower right). c, L. muelleri, Cooktown, Queensland, inflorescence rachis and partial inflorescence, showing rachis bracts with indumentum of scales. $\mathbf{d}$, L. decipiens, Lowmead, Queensland, hastula and lamina base. 

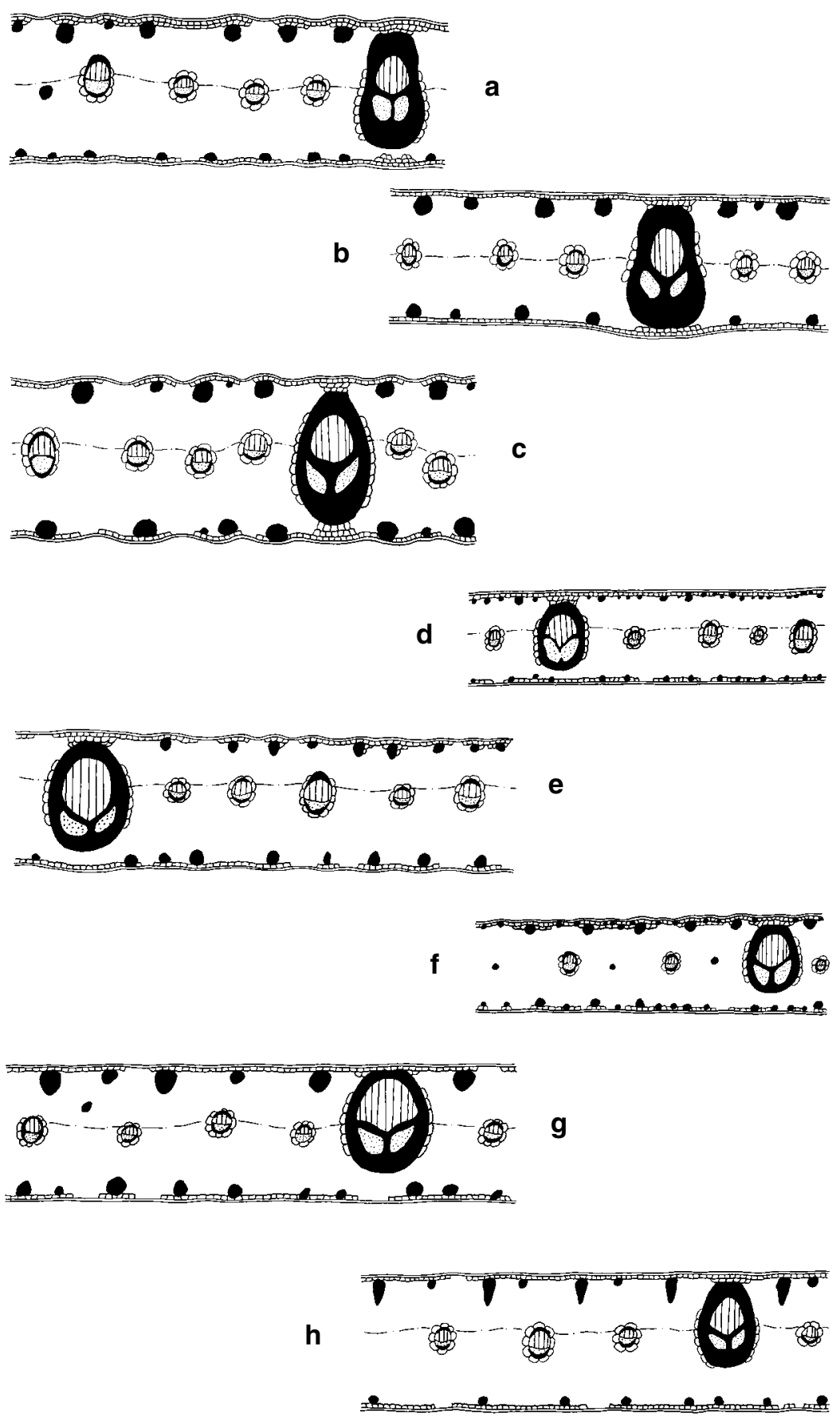

Fig. 3. Transverse sections from leaf lamina segments. a, L. mariae subsp. mariae Rodd 3215. b, L. mariae subsp. rigida Rodd 2937. c, L. mariae subsp. occidentalis Rodd 2868. d, L. lanuginosa Irvine 1912. e, L. benthamii Rodd 2904. f, L. drudei Irvine 1833. g, L. australis Rodd 3030. h, L. nitida Rodd 3055. i, L. decipiens Rodd 3077. Tissues are indicated as in Tomlinson (1961), i.e. sclerenchyma black, xylem hatched, phloem dotted, cells of hypodermis and bundle sheaths shown. Palisade lies above the minor veins and spongy mesophyll below. 

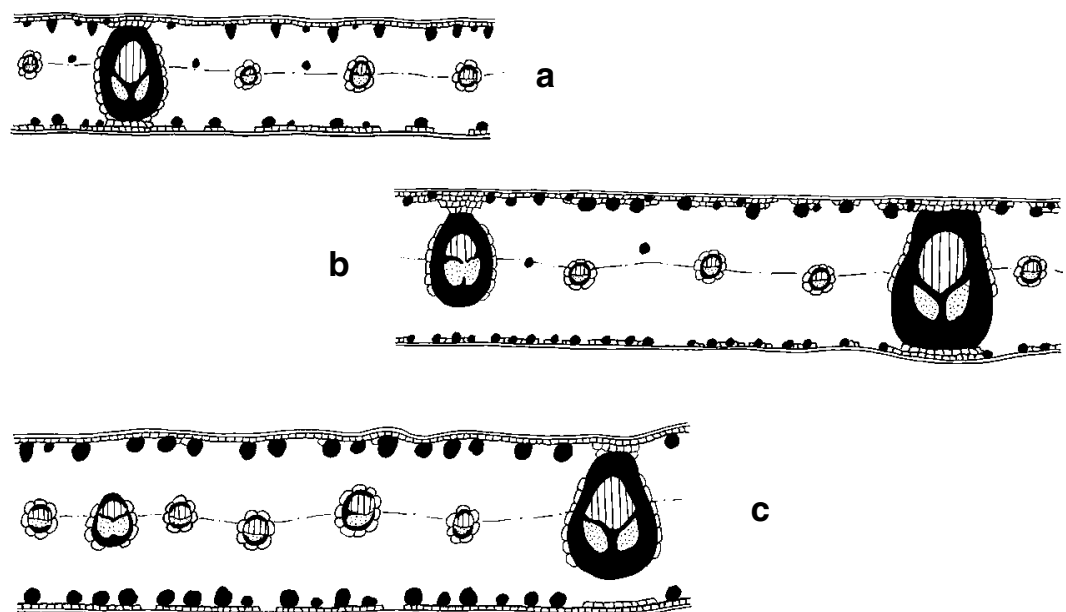

1.2.
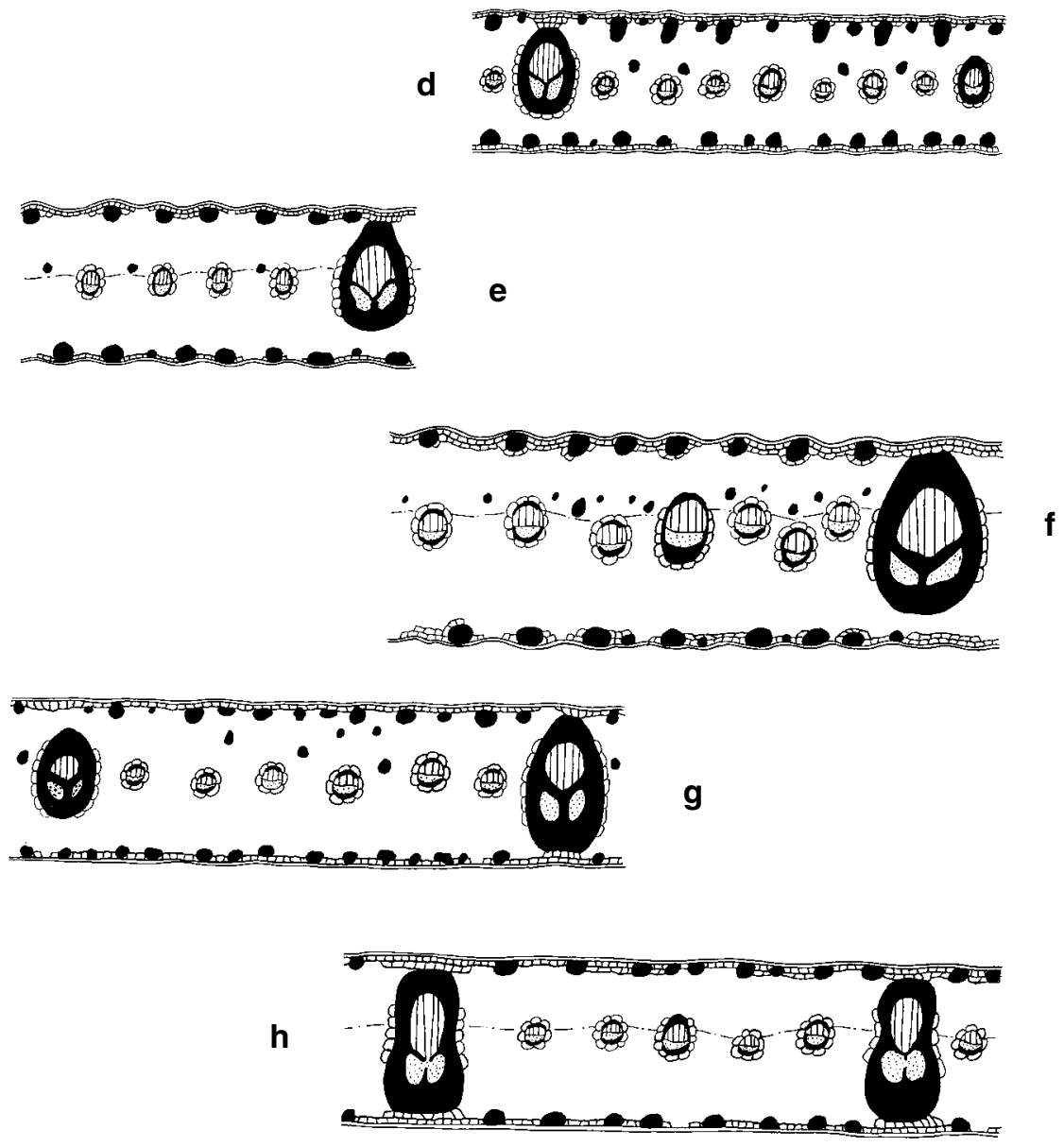

Fig. 4. Transverse sections of leaf lamina. a, L. fulva Rodd 3062. b, L. muelleri Hind 748. c, L. humilis Rodd 2911. d, L. eastonii Rodd 2888. e, L. alfredii Rodd 2848. f, L. victoriae Parker 1065. g, L. kimberleyana Rodd 2866. h, L. lorophylla Kenneally 2162. i, L. inermis Rodd 2931. 

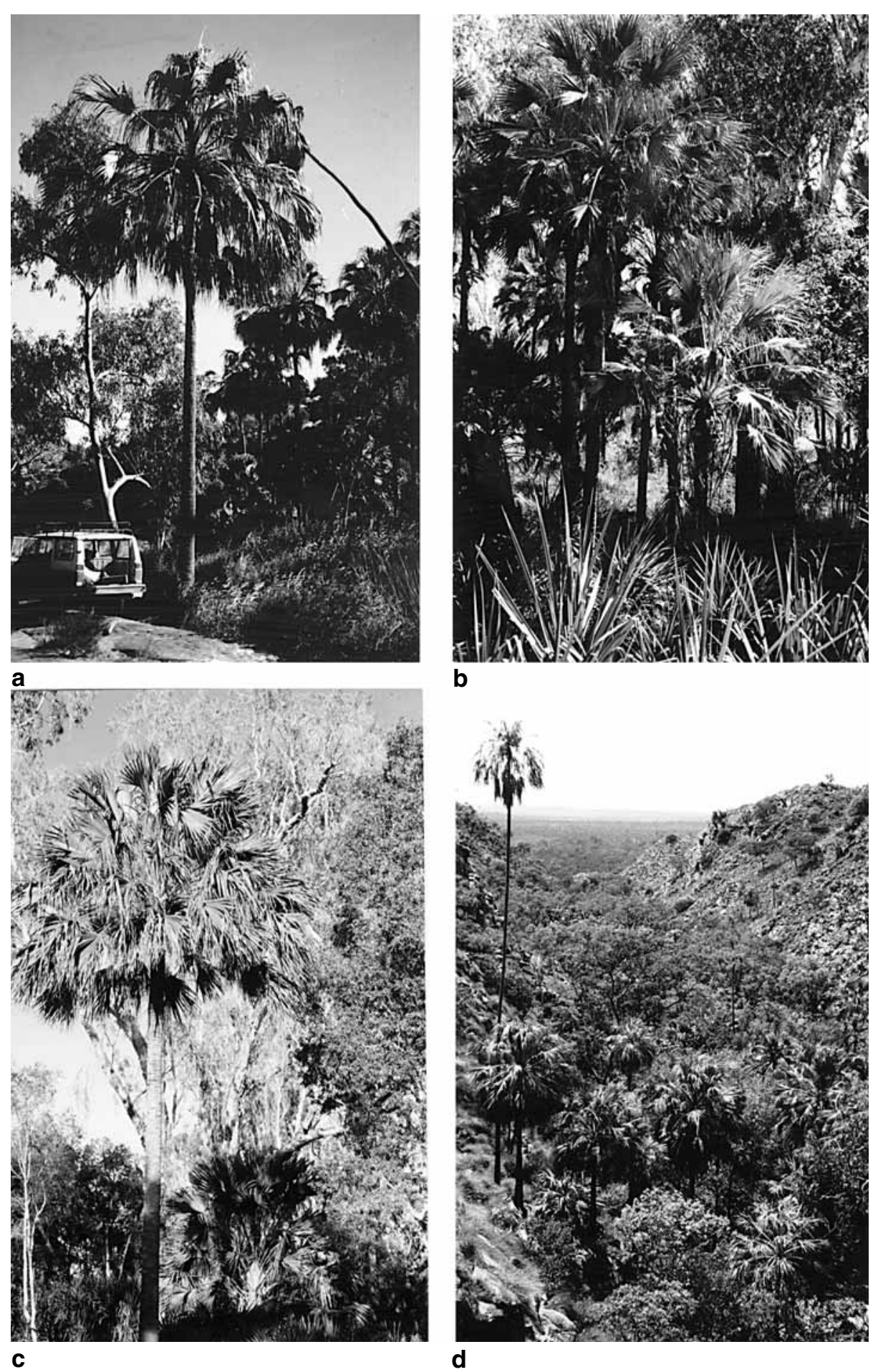

Fig. 5. a, L. mariae subsp. mariae, Palm Valley, Central Australia. b, c, L. mariae subsp. rigida; b, Adels Grove, Queensland; c, Mataranka, Northern Territory. d, L. mariae subsp. occidentalis, Mt King, Durack Range, north Western Australia (Some trees higher on slope are L. kimberleyana). 

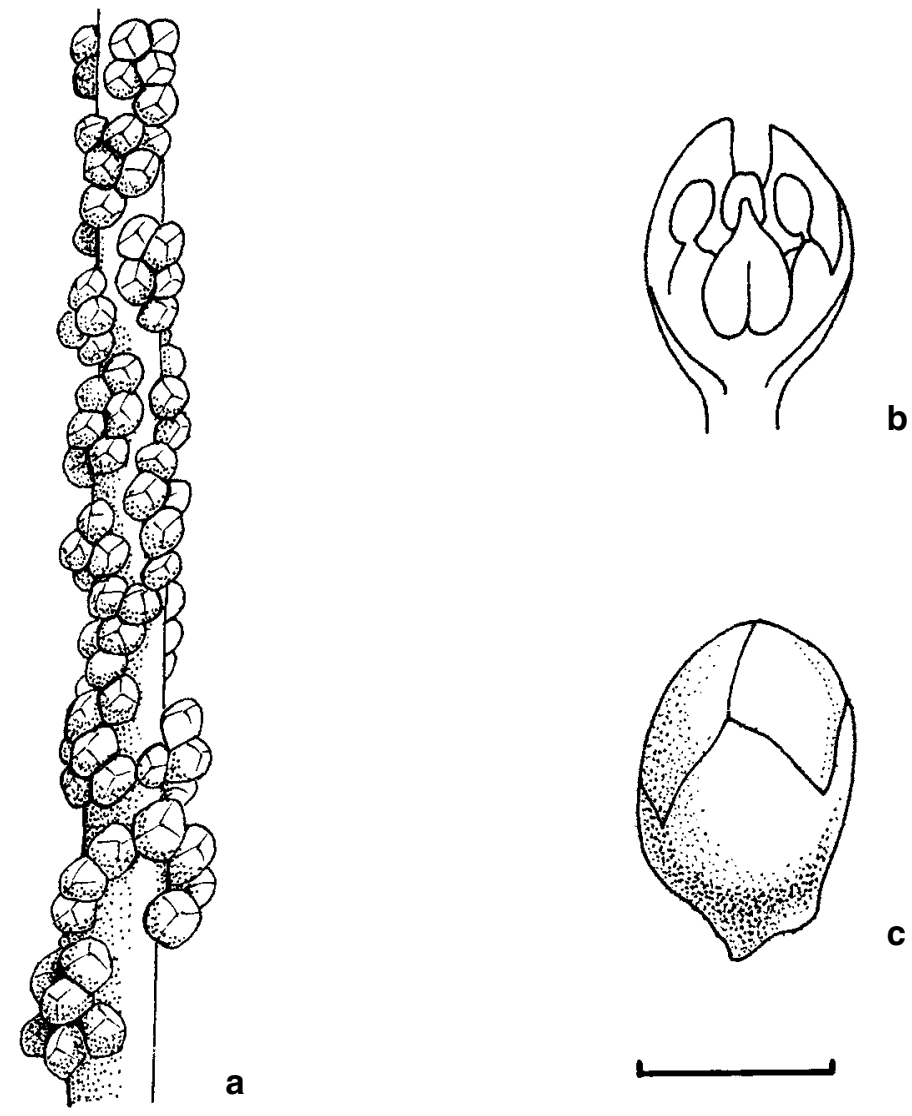

Fig. 6. L. mariae subsp. rigida. a, part of 'female' inflorescence; $\mathbf{b}, \mathbf{c}$, 'female' flower bud. From Latz 7828. Scale bar: $\mathrm{a}=4 \mathrm{~mm} ; \mathrm{b}, \mathrm{c}=1 \mathrm{~mm}$. 

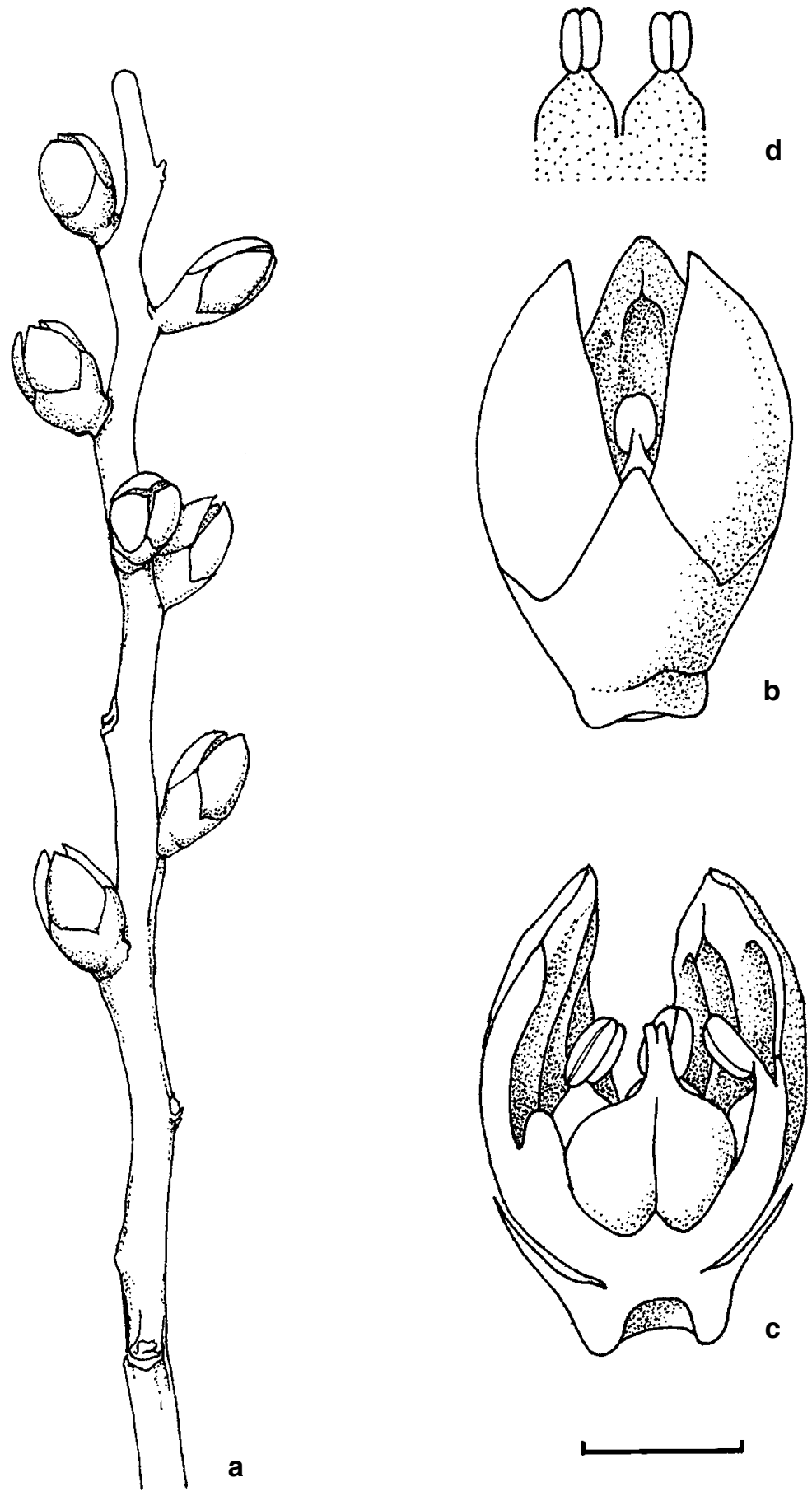

Fig. 7. L. lanuginosa. a, part of 'female' inflorescence; $\mathbf{b}, \mathbf{c}$, 'female' flower; $\mathbf{d}$, stamens. From Irvine 1912. Scale bar: $\mathrm{a}=4 \mathrm{~mm} ; \mathrm{b}-\mathrm{d}=1 \mathrm{~mm}$. 

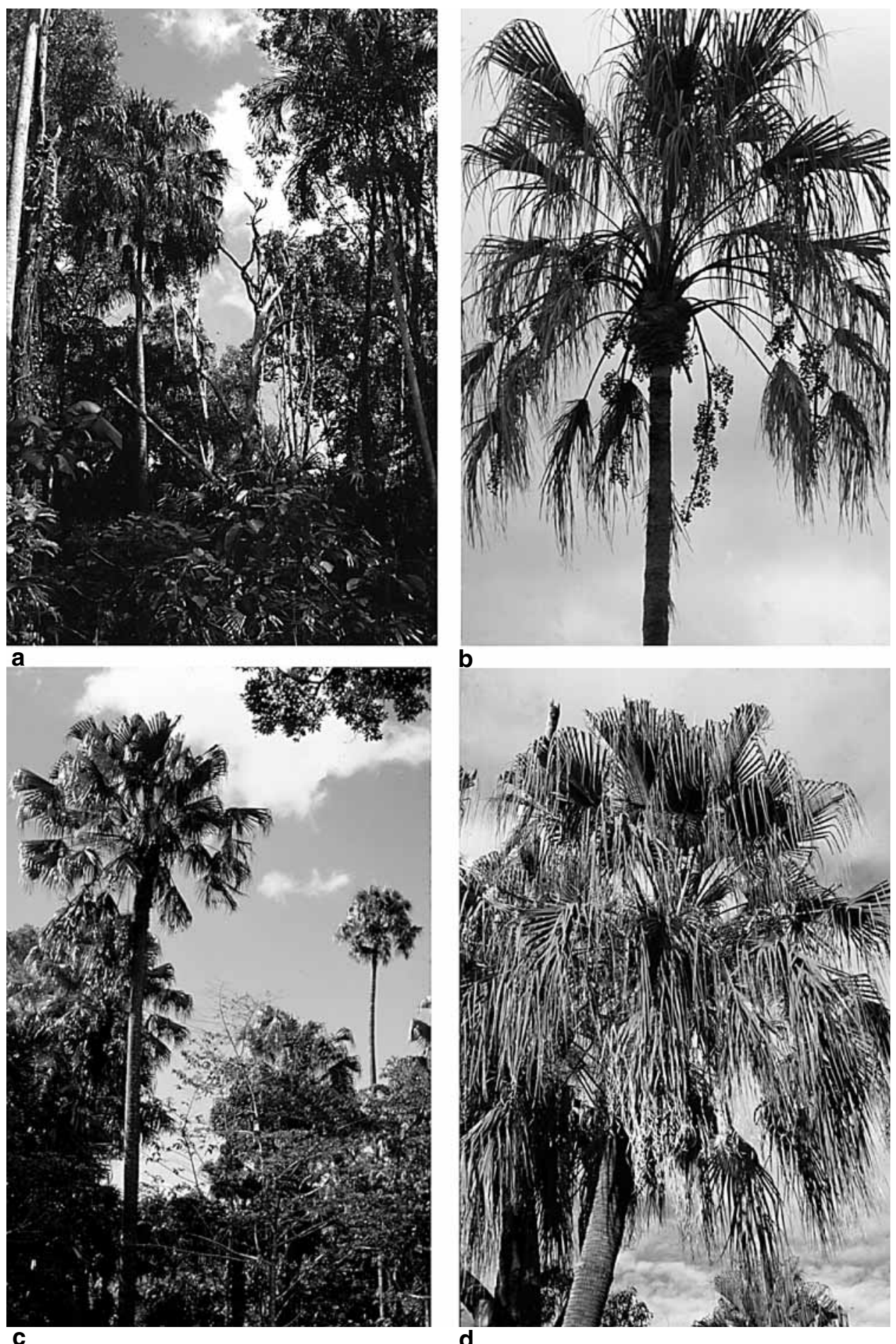

Fig. 8. a, L. benthamii, Howard R. near Darwin, Northern Territory. b, L. drudei, Rollingstone Creek N. of Townsville, Queensland. c, L. australis, Crediton Loop Road, S of Eungella, Queensland. d, L. nitida, Delusion Creek-Dawson R. junction, Queensland. 


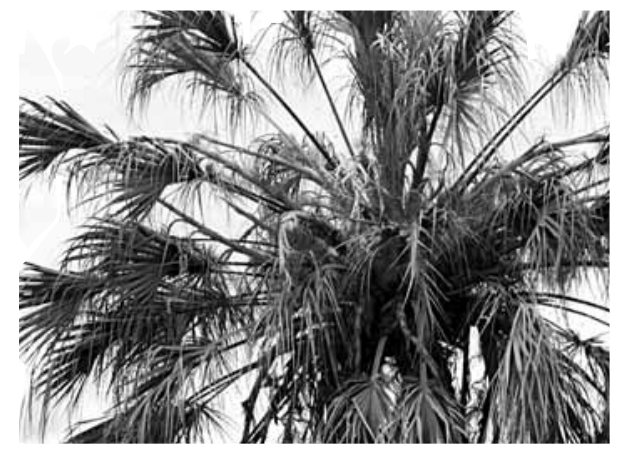

a

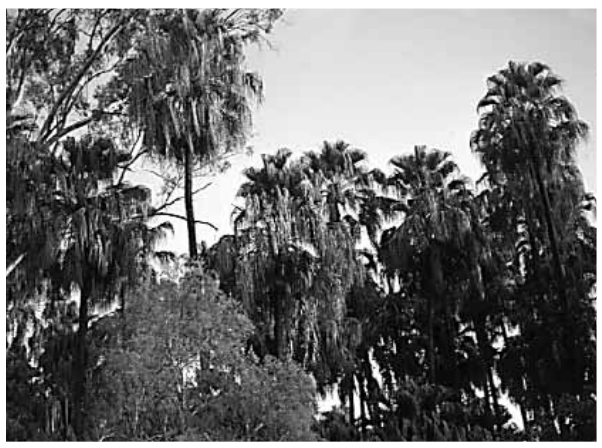

b
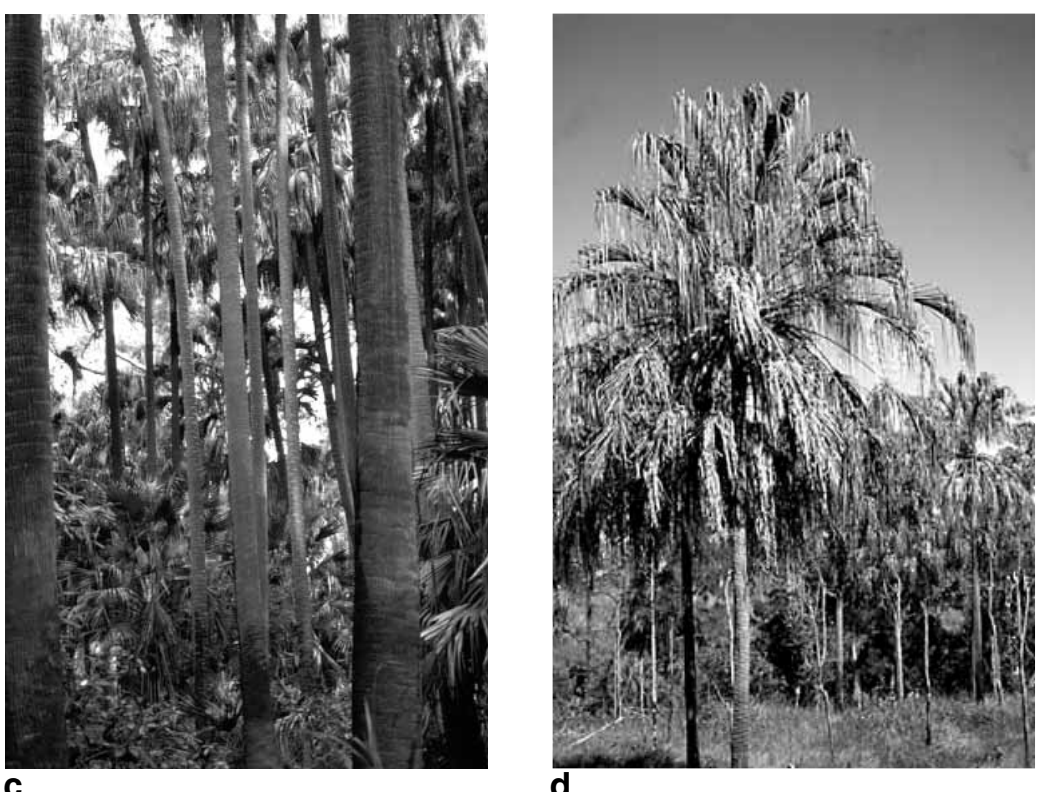

Fig. 9. a, L. lanuginosa, 'Nosnillor' $\mathrm{S}$ of Charters Towers, Queensland. b, c, L. nitida, Delusion Creek-Dawson R. junction, Queensland. d, L. decipiens, Palm Creek S of Miriam Vale, Queensland. 


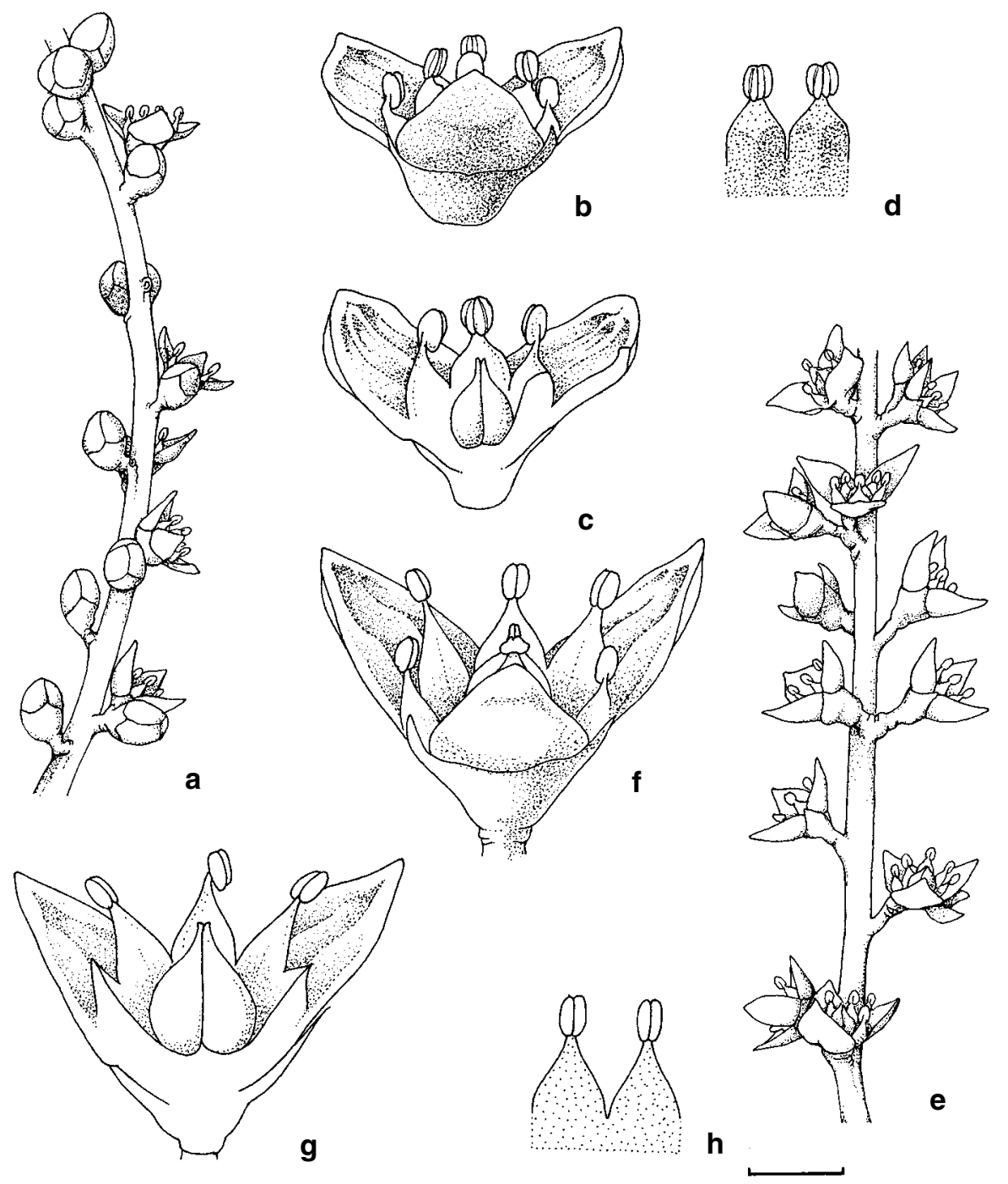

Fig. 10. L. australis. a, part of 'male' inflorescence; $\mathbf{b}, \mathbf{c}$, 'male' flower; $d$, stamens; $\mathbf{e}$, part of 'female' inflorescence; $\mathbf{f}$, 'female' flower; $\mathbf{g}$, partly dissected female flower; $\mathbf{h}$, stamens. a-d from Rodd 2733; e-h from Rodd 2734. Scale bar: a, e = $4 \mathrm{~mm}$; b-d, f-h $=1 \mathrm{~mm}$. 


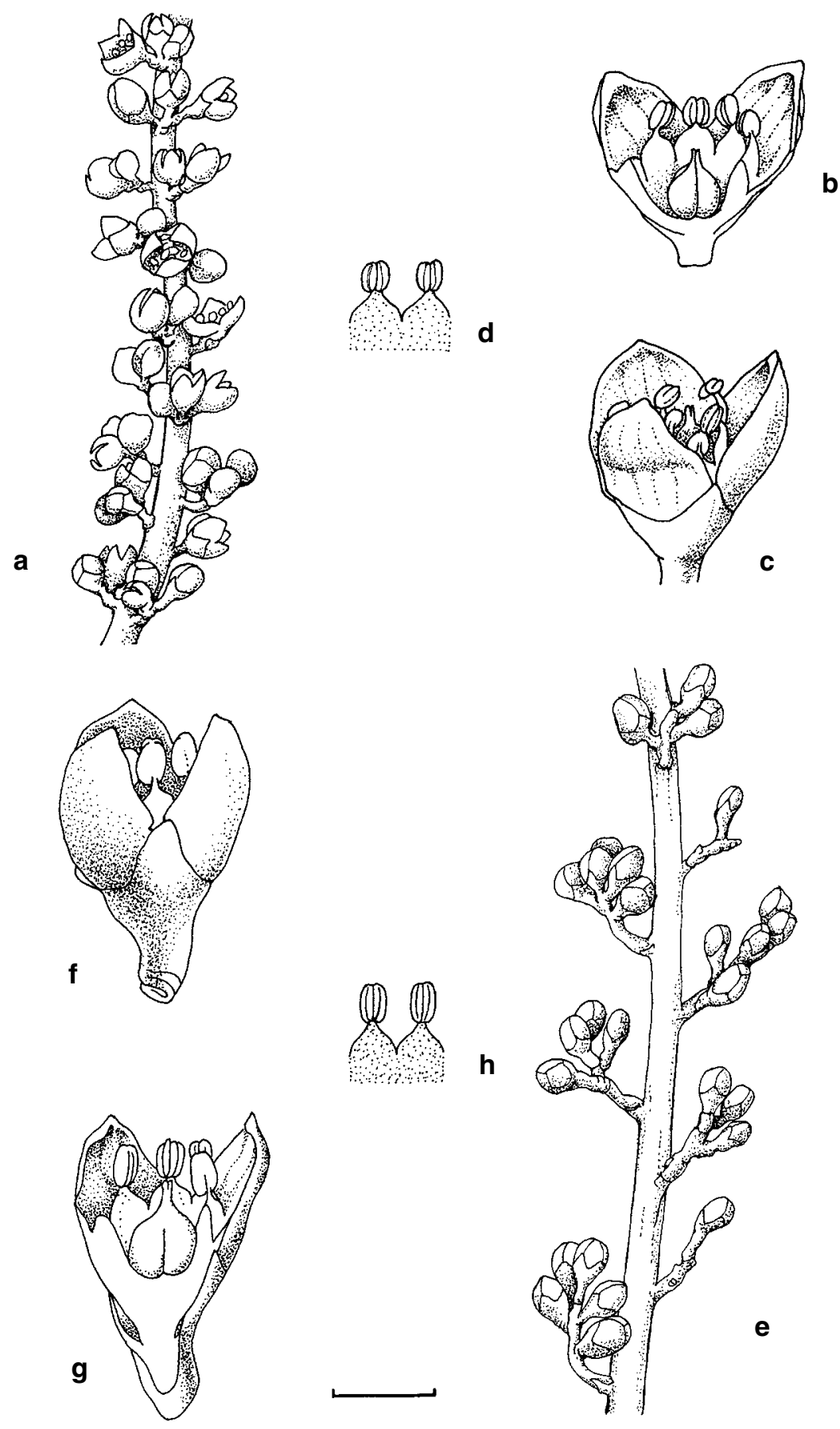

Fig. 11. L. decipiens. $\mathbf{a}$, part of 'male' inflorescence; $\mathbf{b}-\mathbf{c}$ 'male' flower; $\mathbf{d}$, stamens; e, part of 'female' inflorescence and flower cluster; $\mathbf{f}, \mathbf{g}$, 'female' flower; $\mathbf{h}$, stamens. a-d from Hind 662; $\mathrm{e}-\mathrm{h}$ from Briggs 2071. Scale bar: $\mathrm{a}, \mathrm{e}=4 \mathrm{~mm} ; \mathrm{b}-\mathrm{d}, \mathrm{f}-\mathrm{h}=1 \mathrm{~mm}$. 


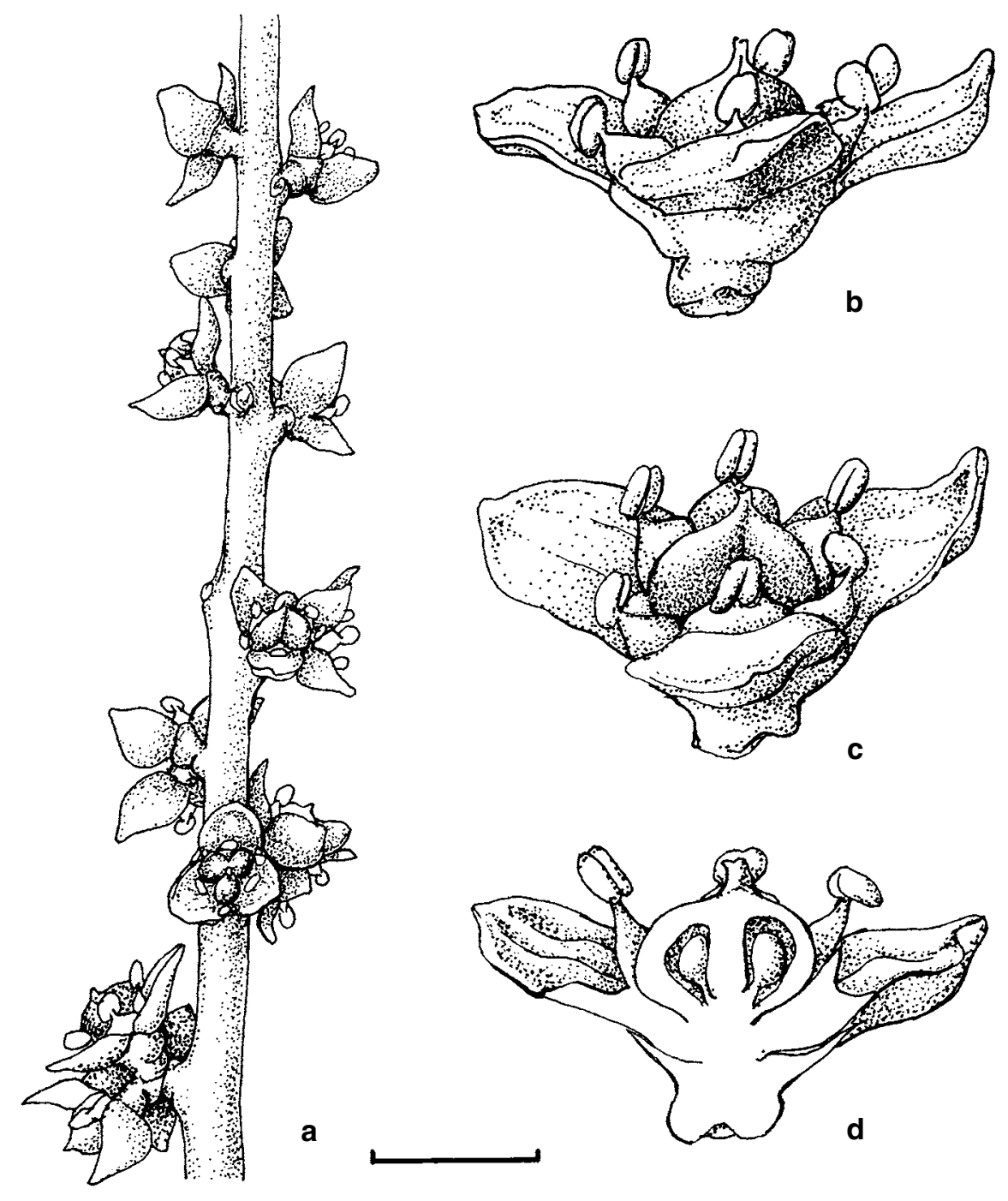

Fig. 12. L. fulva. a, part of inflorescence; $\mathbf{b}-\mathbf{d}$, flowers. From Henderson 1180. Scale bar: a $=4 \mathrm{~mm}$; $\mathrm{b}-\mathrm{d}=1 \mathrm{~mm}$. 

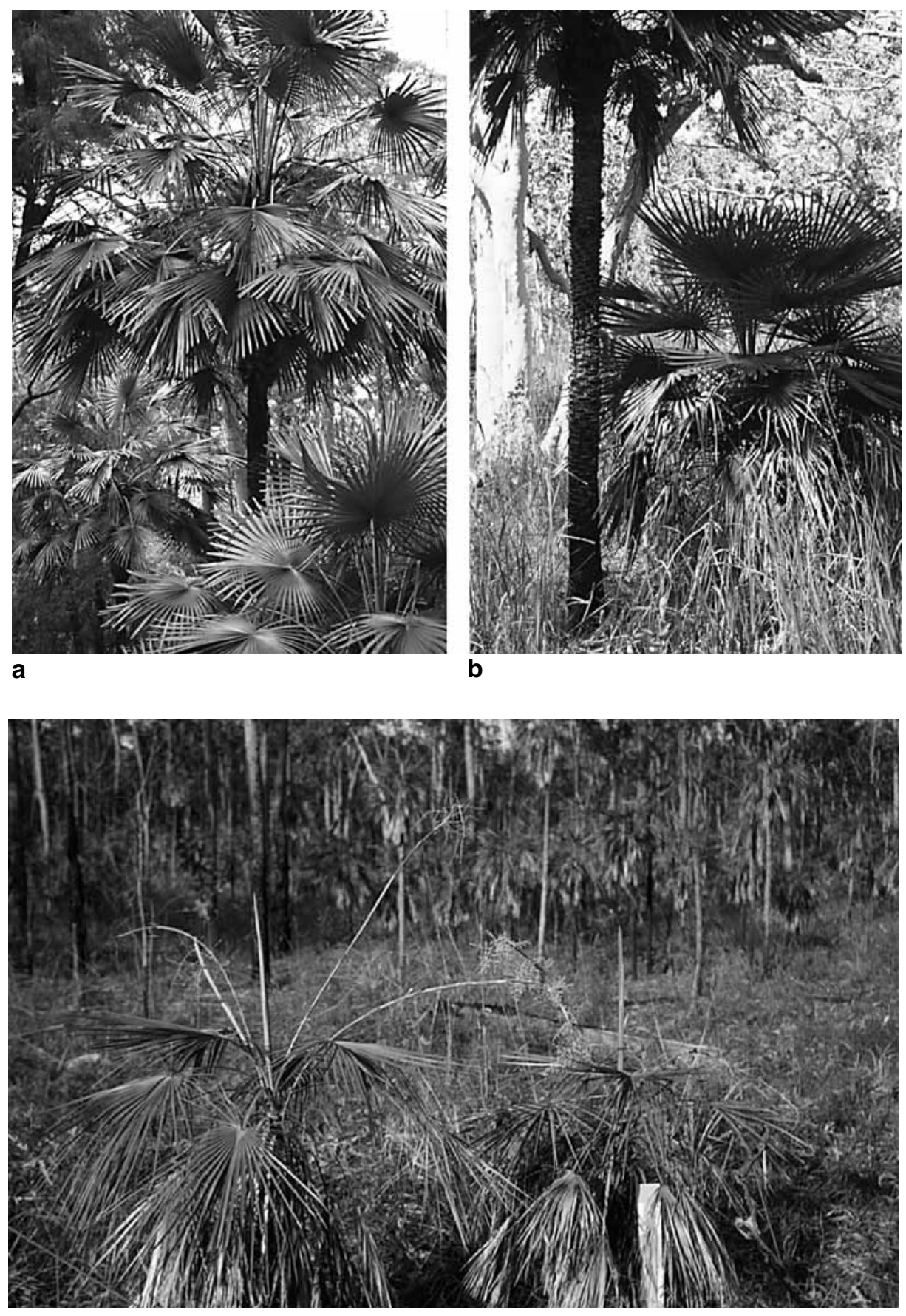

C

Fig. 13. a, L. fulva, Blackdown Tableland, Queensland. b, L. muelleri, WNW of Cooktown, Queensland. c, L. humilis, near Gove, Northern Territory. Plant on left is 'female' with long inflorescence branched only at apex; plant on right is 'male' with shorter, much branched inflorescence (scale bar $0.5 \mathrm{~m}$ long). 


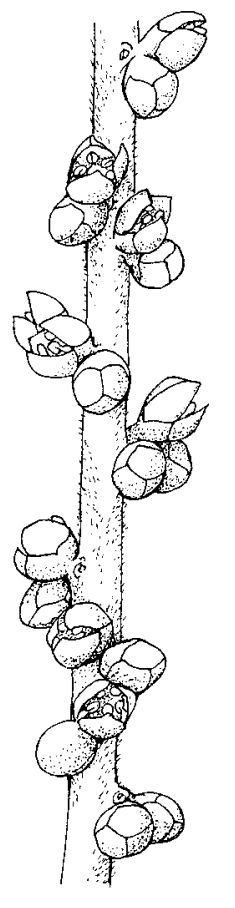

a
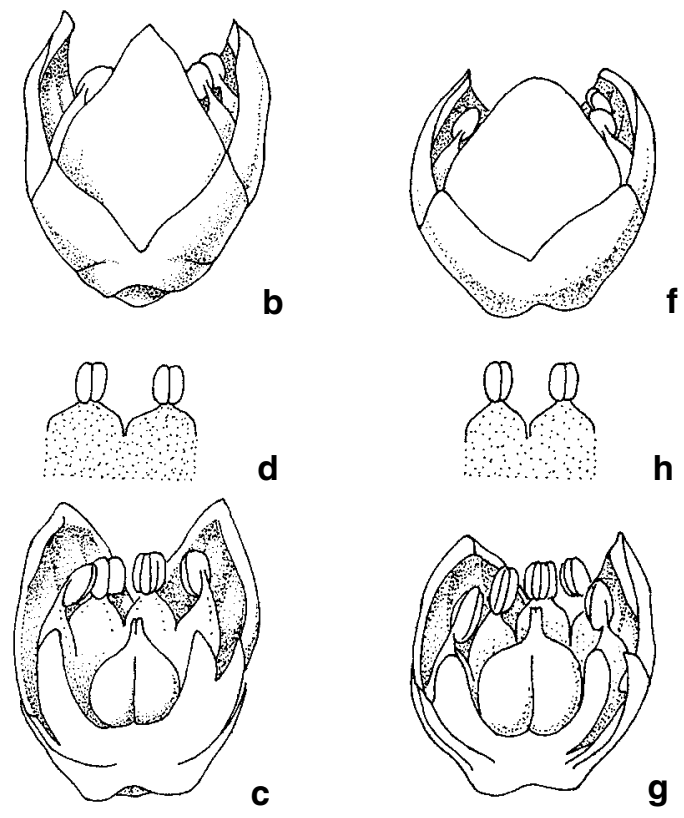

C
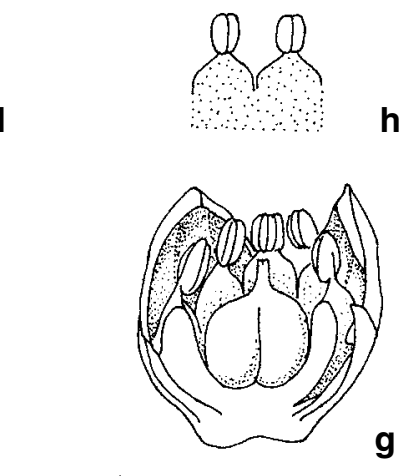

g

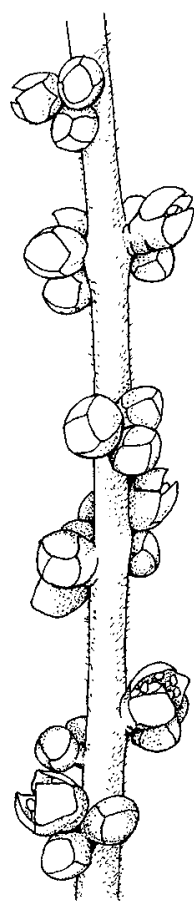

e

Fig. 14. L. humilis. a, part of 'male' inflorescence; b, $\mathbf{c}$, 'male' flower; $\mathbf{d}$, stamens; $\mathbf{e}$, part of 'female' inflorescence; f, $\mathbf{g}$, 'female' flower; $\mathbf{h}$, stamens. a-d from Rodd 2910; $\mathrm{e}-\mathrm{h}$ from Rodd 2911. Scale bar: a, e $=4 \mathrm{~mm} ; \mathrm{b}-\mathrm{d}, \mathrm{f}-\mathrm{h}=1 \mathrm{~mm}$. 

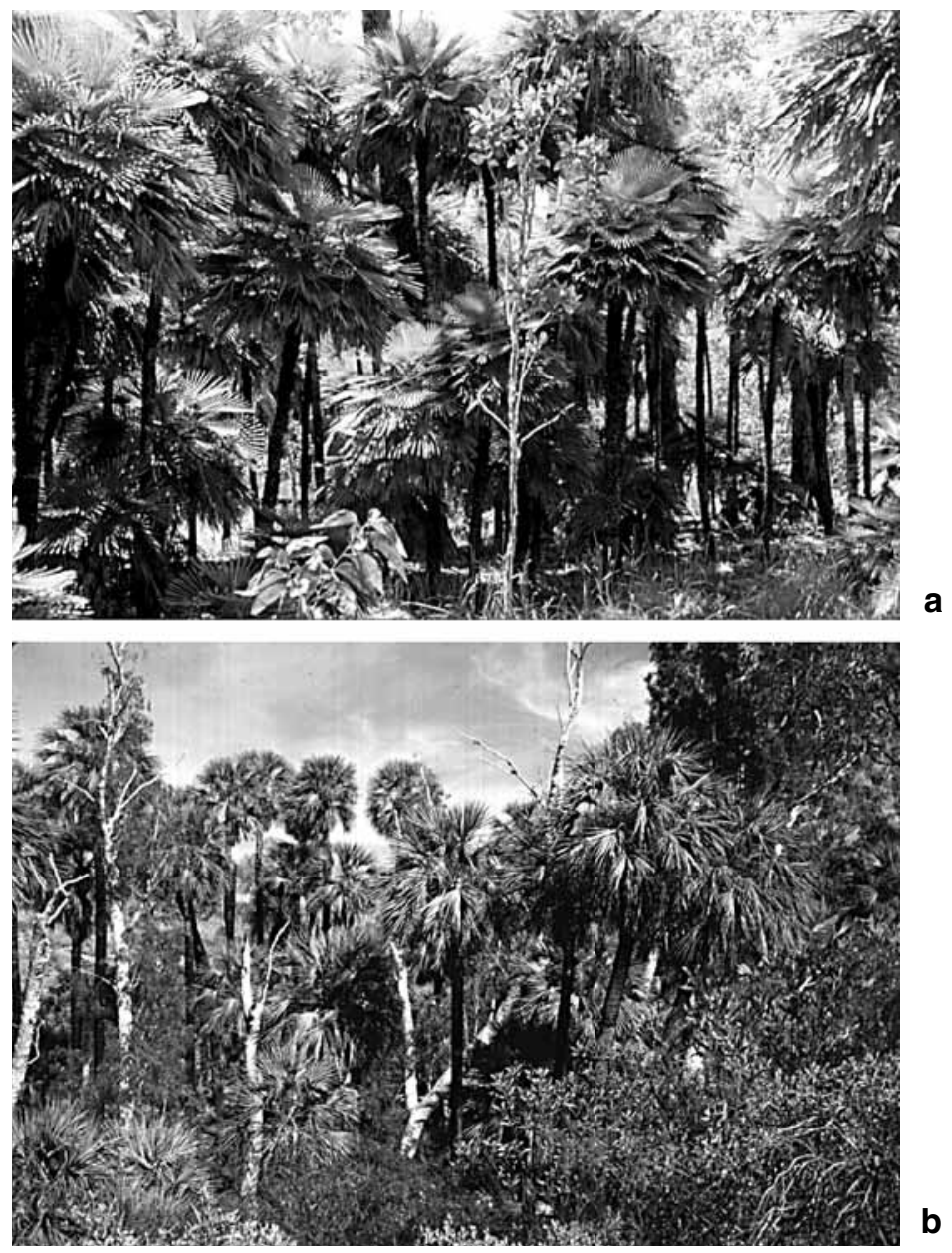

Fig. 15. a, L. muelleri, Silver Plains, north Queensland. b, L. alfredii, near Millstream, northern Western Australia. 

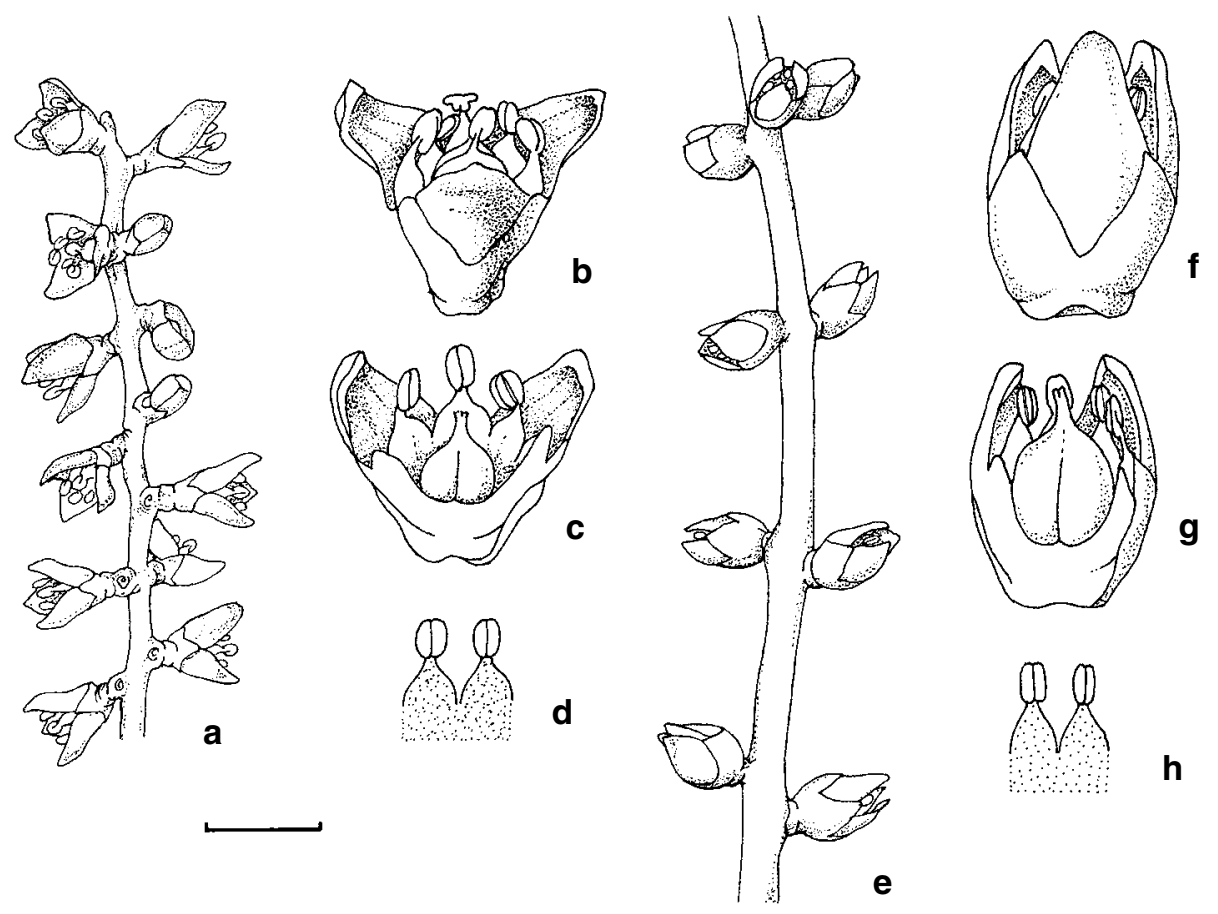

Fig. 16. L. eastonii. $\mathbf{a}$, part of 'male' inflorescence; $\mathbf{b}, \mathbf{c}$, 'male' flower; $\mathbf{d}$, stamens; $\mathbf{e}$, part of 'female' inflorescence; $\mathbf{f}, \mathbf{g}$, 'female' flower; $\mathbf{h}$, stamens. a-d from Rodd 2888; e-h from Rodd 2887. Scale bar: $\mathrm{a}, \mathrm{e}=4 \mathrm{~mm} ; \mathrm{b}-\mathrm{d}, \mathrm{f}-\mathrm{h}=1 \mathrm{~mm}$. 

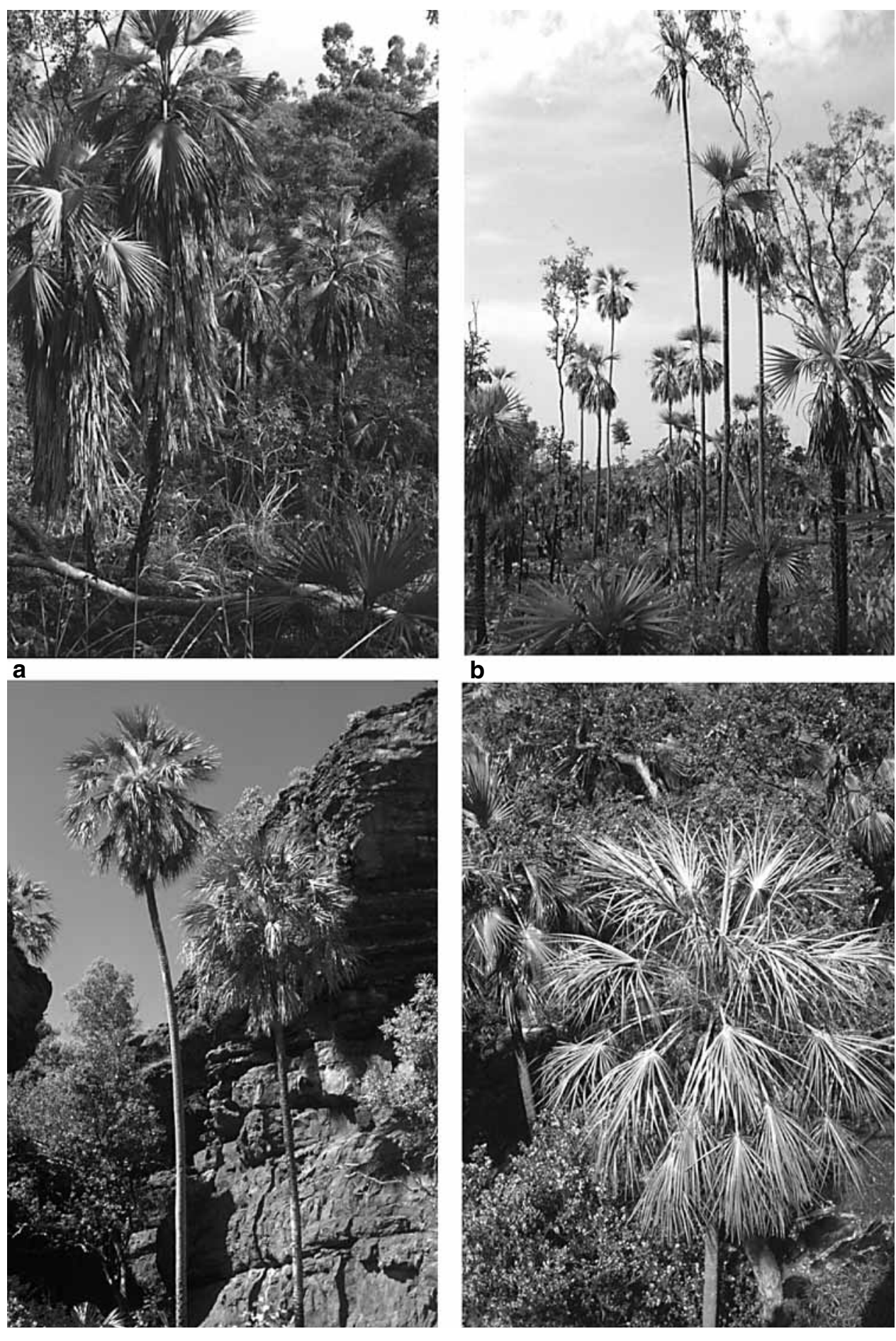

C

d

Fig. 17. a, b, L. eastonii, Mitchell Plateau, north Western Australia. c, L. victoriae, Victoria River, Northern Territory. d, L. kimberleyana, Mt King, Durack Range, north Western Australia. 

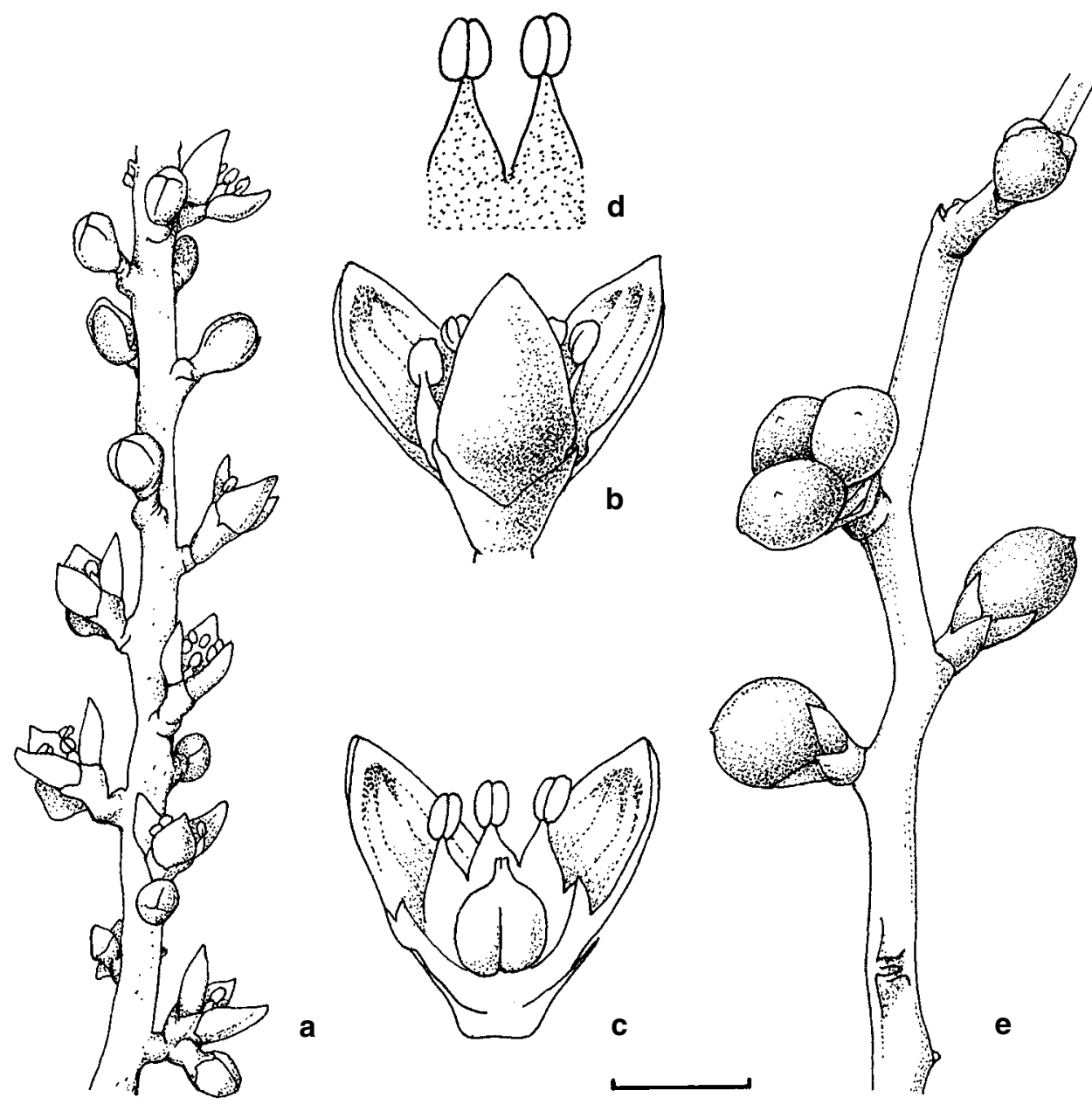

Fig. 18. L. alfredii. a, part of 'male' inflorescence; $\mathbf{b}$, 'male' flower; $\mathbf{c}$, partly dissected 'male' flower; d, stamens; e, part of fruiting inflorescence. a-d from Rodd 2847; e from Rodd 2848. Scale bar: $\mathrm{a}, \mathrm{e}=4 \mathrm{~mm} ; \mathrm{b}-\mathrm{d}=1 \mathrm{~mm}$. 


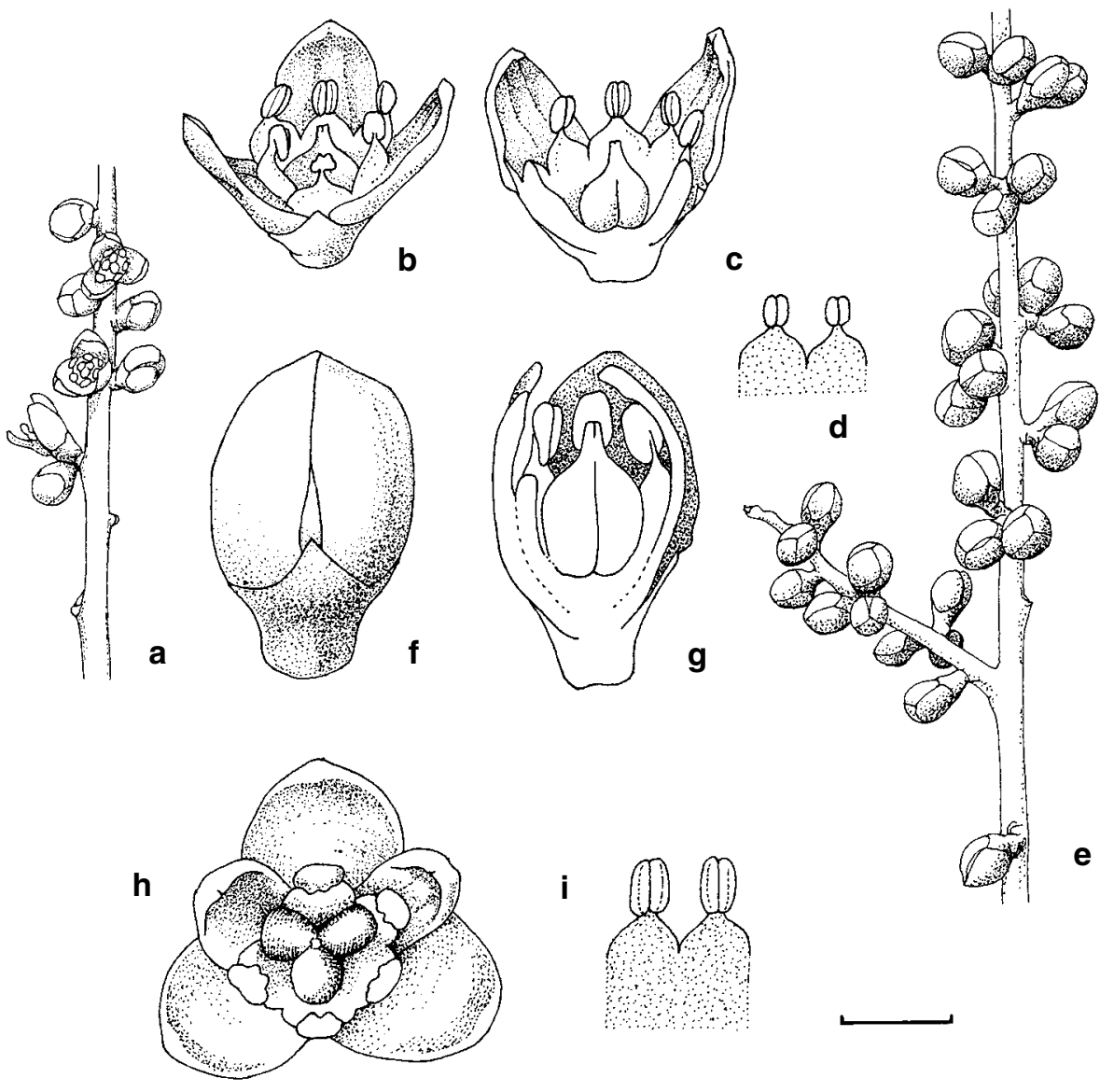

Fig. 19. L. lorophylla. $\mathbf{a}$, part of 'male' inflorescence; $\mathbf{b}, \mathbf{c}$, 'male' flower; $d$, stamens; e, part of 'female' inflorescence; $\mathbf{f}, \mathbf{g}$, 'female' flower bud; $\mathbf{h}$, bud opened out; $\mathbf{i}$, stamens. a-d from Johnson s.n, isotype; e-i from Kenneally 4153. Scale bar: a, e = $4 \mathrm{~mm} ; \mathrm{b}-\mathrm{d}, \mathrm{f}-\mathrm{i}=1 \mathrm{~mm}$. 

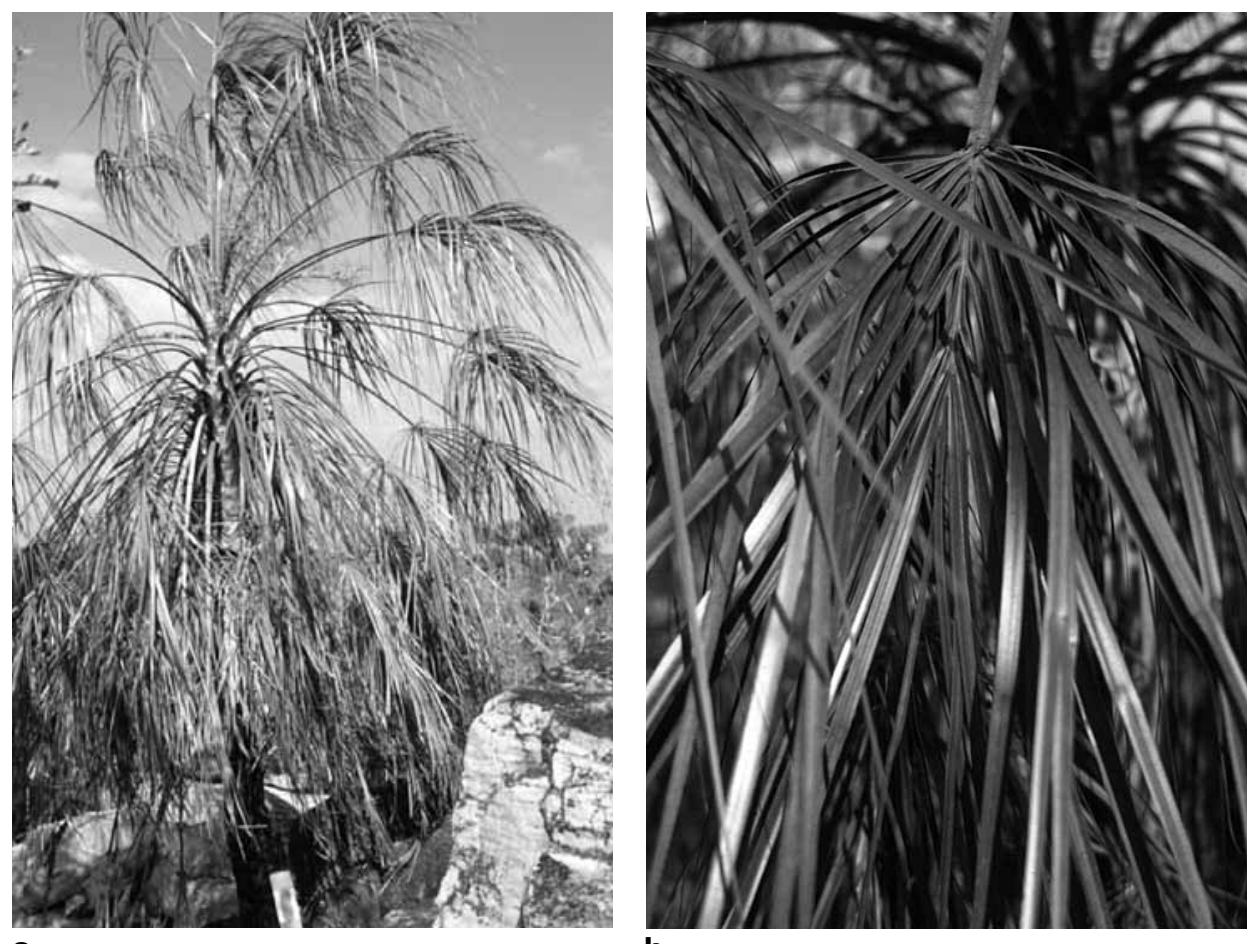

a
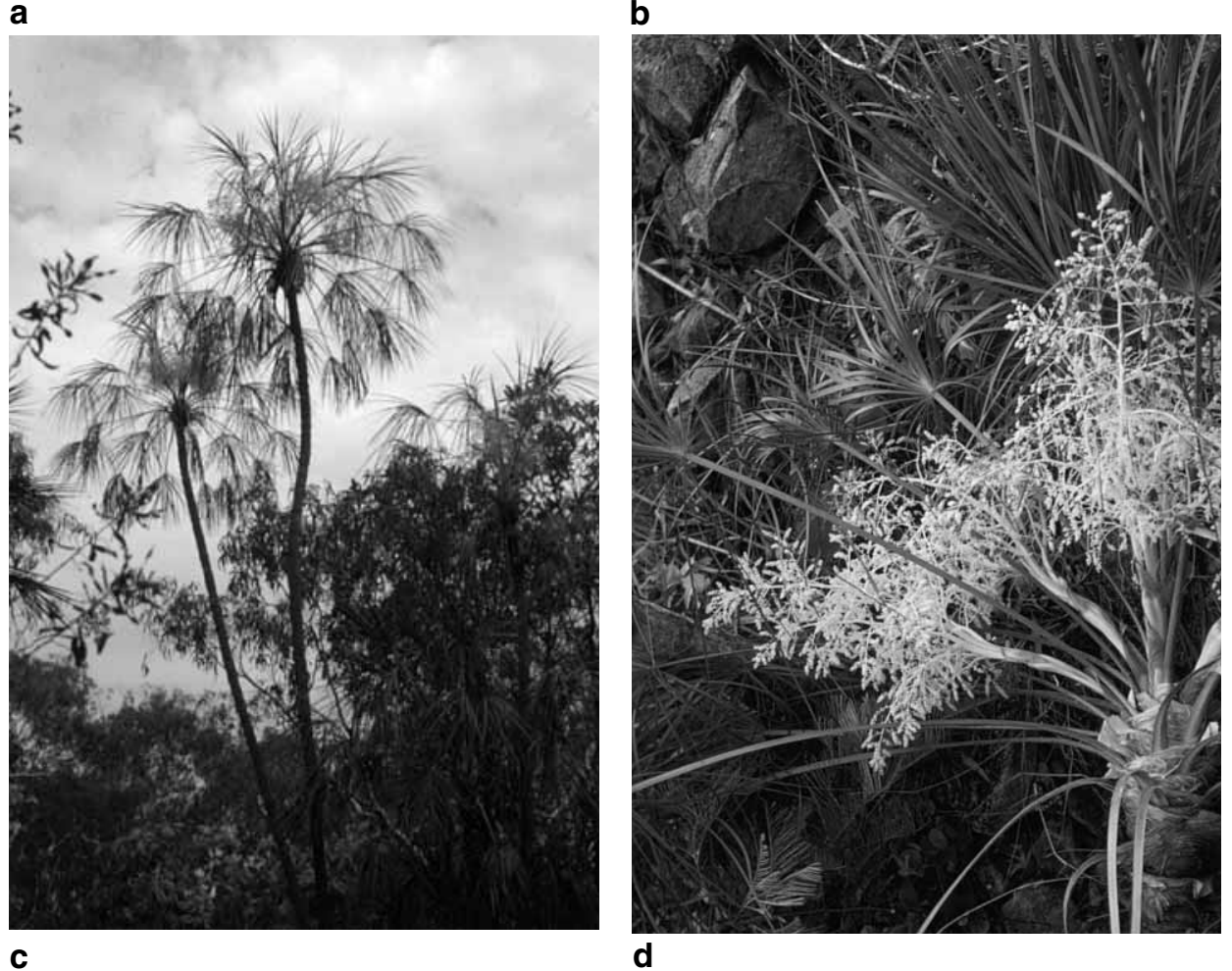

Fig. 20. a, b, L. lorophylla, Kalumburu, north Western Australia: a, habit (scale bar $0.3 \mathrm{~m}$ long); b, leaf. $\mathbf{c}$, d, L. inermis, Katherine Gorge, Northern Territory: c, habit, note basal branching; d, fallen crown with 3 inflorescences at anthesis. 


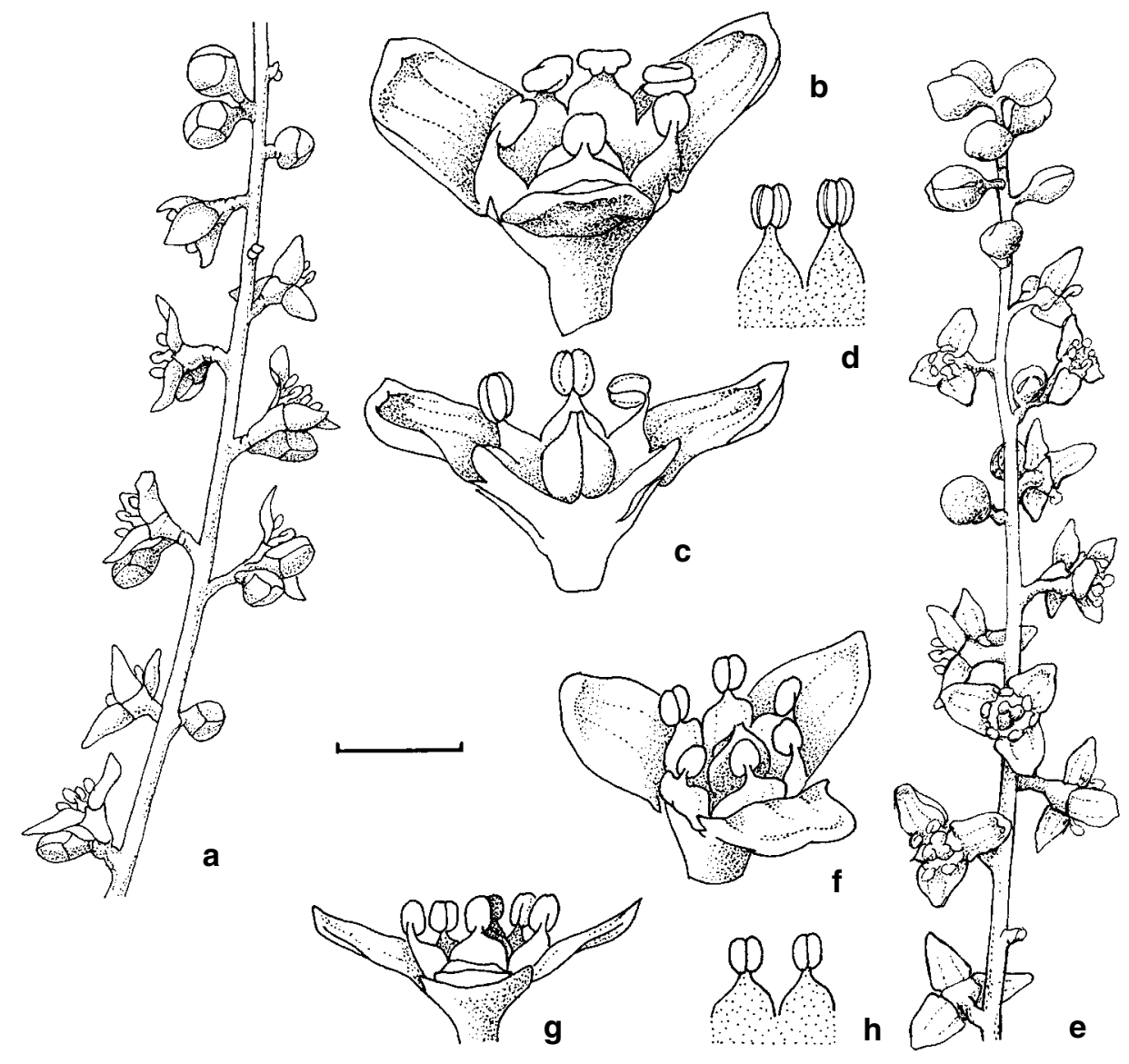

Fig. 21. L. inermis. a, part of 'male' inflorescence; $\mathbf{b}, \mathbf{c}$ 'male' flower; $\mathbf{d}$, stamens; $\mathbf{e}$, part of 'female' inflorescence; $\mathbf{f}$, $\mathbf{g}$, 'female' flowers; $\mathbf{h}$, stamens. a-d from Rice 2037; e-h from Rodd 2931. Scale bar: $\mathrm{a}, \mathrm{e}=4 \mathrm{~mm} ; \mathrm{b}-\mathrm{d}=1 \mathrm{~mm} ; \mathrm{f}-\mathrm{h}=1.2 \mathrm{~mm}$. 
